\title{
The Fiscal and Economic Impact of Qualifying Industrial Zones The Case of Jordan
}

\author{
Dissertation \\ zur Erlangung des wirtschaftswissenschaftlichen Doktorgrades \\ der Wirtschaftswissenschaftlichen Fakultät \\ der Georg-August-Universität zu Göttingen
}

\author{
Vorgelegt von \\ Metri Fayez Al Mdanat \\ aus Karak / Jordanien
}

Göttingen, 2006 
Referent: Prof. Dr. Kilian Bizer

Korreferent: Prof. Dr. Michael Grimm

Tag der mündlichen Prüfung: 20/12/2006 


\title{
DEDICATION
}

\author{
To my \\ Mother, Father, Sisters and Brothers
}

with love and thanks for all they have done for me

Göttingen, 2006 


\section{SUMMARY}

This thesis investigates the fiscal and economic impact of Qualifying Industrial Zones (QIZs) on the Jordanian economy. In contrast to other studies, this study assesses costs and benefits of establishing such zones in Jordan. Fiscal as well as economic issues are investigated to clarify the impact of QIZs on the host country.

This QIZ agreement pursued political aims more than broad economic goals, as QIZs were designed to ameliorate relations between Israel and Jordan. They were also expected to improve relations between Israel and other Arab countries through the cooperation required to get duty-free access to the USA market.

Most countries consider special economic zones, such as QIZs, engines for growth, but empirical evidence from many countries in the world shows that the impact of various economic zones on growth is mixed. It has been assumed that QIZs play a significant role in increasing exports and earning foreign currency. However, ignoring the offsetting effects of imports is misleading. Depending heavily on an export-led growth strategy to stimulate and accelerate economic growth in the country should be viewed in light of increased imports of production inputs.

The most important effects resulting from the establishment of QIZs are on employment and poverty. According to this analysis, QIZs contribute positively to the welfare of the poor in the country by increasing employment opportunities for unemployed and unskilled persons.

QIZs prove ineffective at creating backward and forward linkages with the local economy. Although some effects may be observable, they are not necessarily large or immediate.

Tax incentives are one of the main negative effects of the QIZs on the local economy, as they do not have much influence on investors and thus are a waste of resources. Other factors, like the economic and political stability and the quota and duty-free exports to the USA market, are much more important. The generous incentives that the country offers to attract investors 
should be connected to increasing levels and degrees of technological sophistication of the products.

As a result of this thesis, a set of policy options were derived. Economic data about the QIZs are impressive, but improvements in political relations are far less so. The history of QIZs was found to be a mixture of failures and successes. It is important to take the actual political situation of the country into account before establishing such zones. The concept of these zones is complex policy instrument to be used in a time of regional conflicts as is the case now. It is more important to establish these zones according to the needs of the country.

Establishing QIZs might benefit some areas, but it takes a long time before the gains are visible throughout the whole country. In conclusion, QIZs are but one policy to be considered and the government must still try to find alternatives that better suit the needs of the country. Furthermore, in the absence of the role of tax incentives in the investors' decisions, the QIZs should not be exempt from taxes.

The government must also provide incentives to hire local workers. If this is not built into the QIZ agreement, the country may find that it creates zones that end up employing mostly foreign workers. One strategy is to gradually phase out foreign workers, replacing them with local ones as the latter's skills and knowledge of the business increase.

Finally, it is possible to preserve Jordan's QIZs in the future if a set of measures are undertaken. These include applying value added brackets from the Israeli side depending on the volume of production and decreasing the prices of the inputs from the Israel side to make the companies in Jordan's QIZs more cost competitive. The future of the QIZs also depends on USA's government policies. In order to be viable, the QIZs need more privileges in order to distinguish QIZs from other agreements. These changes will work together to create a healthy investment climate in Jordan. 


\section{ZUSAMMENFASSUNG}

Untersuchungsgegenstand der vorliegenden Arbeit sind die fiskalischen und ökonomischen Auswirkungen von speziellen Sonderwirtschaftszonen - den sogenannten Qualifying Industrial Zones (QIZs) - auf die jordanische Wirtschaft. Im Gegensatz zu anderen Studien werden in dieser Studie Kosten und Nutzen der Einführung von QIZs in Jordanien geschätzt. Sowohl fiskalische als auch ökonomische Probleme werden untersucht, um die Gesamtwirkung der QIZs auf das Gastland zu klären.

Mit dem Abkommen über die QIZs wurden eher politische denn wirtschaftliche Ziele verfolgt: Die QIZs wurden konzipiert, um eine Verbesserung in den Beziehungen zwischen Israel und Jordanien herbeizuführen. Darüber hinaus sollten sie auch durch die erforderliche Kooperation, die notwendig ist, um zollfreien Zugang auf den US-Markt zu bekommen, die Beziehungen zwischen Israel und anderen arabischen Ländern verbessern.

In den meisten Ländern werden Sonderwirtschaftszonen wie die QIZs als Wachstumsmotoren betrachtet, obwohl empirische Ergebnisse aus vielen Ländern der Welt zeigen, dass die Wirkungsrichtung von diversen Sonderwirtschaftszonen auf das Wirtschaftswachstum nicht eindeutig ist. Ursprünglich wurde angenommen, dass QIZs eine bedeutende Rolle für die Steigerung von Ausfuhren und Deviseneinnahmen spielen. Jedoch führt das Vernachlässigen der zugleich auftretenden Einfuhreffekte zu

Fehleinschätzungen. Bei der Bewertung einer Strategie, die zur Stimulierung und Beschleunigung des Wirtschaftswachstums primär auf exportinduziertes Wachstum setzt, sollten die anwachsenden Importe von Produktionsinputs berücksichtigt werden.

Die größten Effekte aus der Einführung von QIZs ergaben sich mit Bezug auf die Beschäftigung und die Entwicklung der Armut. Nach der vorliegenden Untersuchung haben QIZs einen positiven Wohlfahrtseffekt für die Armen im Gastland, da sie die Beschäftigungsmöglichkeiten für arbeitslose und ungelernte Arbeitskräfte erhöhen. 
QIZs erweisen sich ineffektiv im Hervorrufen von Koppelungseffekten (forward linkages und backward linkages) mit der lokalen Ökonomie. Obwohl einige Effekte beobachtbar sind, sind sie nicht notwendigerweise von erheblichem Umfang und unmittelbarer Wirkung.

Eine der wichtigsten negativen Auswirkungen von QIZs auf die lokale Ökonomie resultiert aus Steueranreizen, welche kaum Einfluss auf die Investoren zeigen und daher eine Verschwendung von Ressourcen darstellen. Demgegenüber spielen andere Faktoren, wie die ökonomische und politische Stabilität, die Höhe des Ausfuhrkontingents sowie die Eröffnung der Möglichkeit zu zollfreien Exporten auf den US-Markt, eine weitaus wichtigere Rolle. Die großzügigen Anreize, die das Land gewährt, um Investoren anzuziehen, sollten verknüpft werden mit der Zielsetzung einer Steigerung des technologischen Entwicklungsgrades der Produkte.

Ein Ergebnis dieser Arbeit stellt die Ableitung einer Reihe von Politikoptionen dar. Während die Wirtschaftsdaten über die QIZs ein beeindruckendes Bild wiedergeben, ist dies bei den angestrebten Verbesserungen in den außenpolitischen Beziehungen weitaus weniger der Fall. Bei der Aufarbeitung der Geschichte der QIZs zeigte sich, dass diese insgesamt aus einer Mischung aus Misserfolgen und Erfolgen besteht. Vor der Einführung derartiger Zonen sollte unbedingt die konkrete politische Lage des Landes berücksichtigt werden. Das Konzept dieser Zonen stellt ein zu komplexes politisches Instrument dar, um in Zeiten von regionalen Konflikten, wie es aktuell der Fall ist, eingesetzt zu werden. Noch wichtiger ist, dass sich bei der Einführung solcher Zonen an den Bedürfnissen des Gastlandes orientiert wird.

Die Gründung von QIZs kann einigen Gebieten unmittelbar nützen, aber es vergeht eine lange Zeit bevor diese Nutzen auch für das ganze Land bemerkbar werden. Als Fazit kann festgehalten werden, dass QIZs nur eine von vielen in Betracht kommenden Politikoptionen darstellen und dass die Regierung weiterhin versuchen muss Alternativen zu finden, die besser zu den Bedürfnissen des Landes passen. Weiterhin sollten, angesichts der Bedeutungslosigkeit von Steueranreizen für die Entscheidungen der Investoren, QIZs nicht von Steuern befreit werden. 
Auch sollte die Regierung Anreize setzen, die Beschäftigung lokaler Arbeitskräfte zu erhöhen. Wenn dies nicht Bestandteil des QIZ-Abkommens ist, läuft das Gastland Gefahr Zonen zu schaffen, in denen schließlich überwiegend ausländische Arbeitskräfte beschäftigt werden. Eine Lösungsstrategie hier wäre, die Beschäftigung ausländischer Arbeitskräfte allmählich auslaufen zu lassen und mit zunehmenden Fähigkeiten und Kenntnissen der lokalen Arbeitskräfte durch Letztere zu ersetzen.

Abschließend sei darauf verwiesen, dass es möglich ist, die jordanischen QIZs für die Zukunft zu erhalten, wenn eine Reihe von Maßnahmen unternommen werden. Diese schließen eine Begrenzung des israelischen Wertschöpfungsanteils in Abhängigkeit vom Produktionsvolumen sowie ein Absenken der Preise für die israelischen Inputs ein, um die Unternehmen in den jordanischen QIZs auf der Kostenseite wettbewerbsfähiger zu machen. Die Zukunft der QIZs hängt auch von der zukünftigen Regierungspolitik der USA ab. Um existenzfähig zu bleiben, brauchen die QIZs mehr Handelsprivilegien, damit sie sich gegenüber anderen Abkommen durchsetzen können. Die vorgeschlagenen Veränderungen werden in ihrer Gesamtheit für ein günstiges Investitionsklima in Jordanien sorgen. 


\section{TABLE OF CONTENTS}

DEDICATION.....................................................................................................III

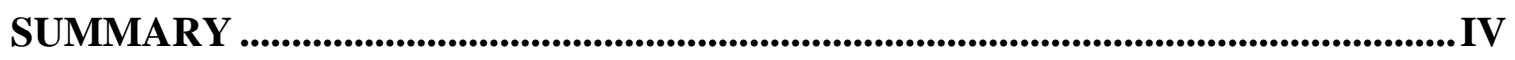

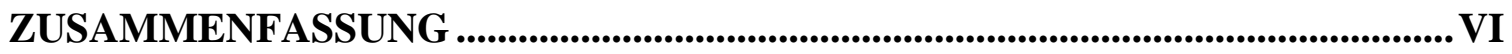

TABLE OF CONTENTS ...................................................................................... $\mathrm{X}$

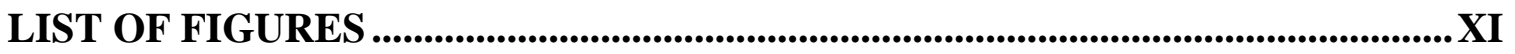

LIST OF TABLES ......................................................................................................... XII

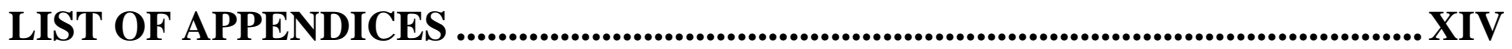

LIST OF ABBREVIATIONS .................................................................................

CHAPTER 1: INTRODUCTION............................................................................. 1

CHAPTER 2: QUALIFYING INDUSTRIAL ZONES AND FREE ZONES ............. 5

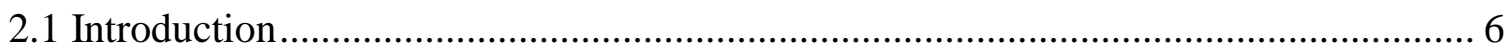

2.2 Definition of Free Zones....................................................................................... 6

2.3 Definition of Qualifying Industrial Zones ................................................................ 6

2.4 Comparing Qualifying Industrial Zones and Free Zones ............................................. 7

2.5 The Idea of Qualifying Industrial Zone .................................................................. 8

2.6 The Enclave Model ........................................................................................... 9

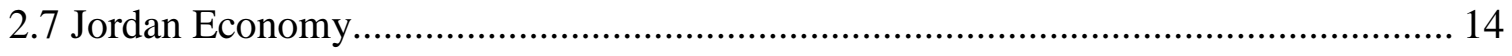

2.8 External Sector Performance .............................................................................. 15

2.9 Jordan’s Foreign Trade Policy ............................................................................... 16

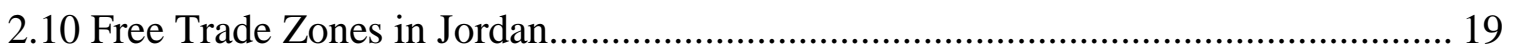

CHAPTER 3: LITERATURE REVIEW ................................................................... 23

3.1 Introduction .................................................................................................... 23

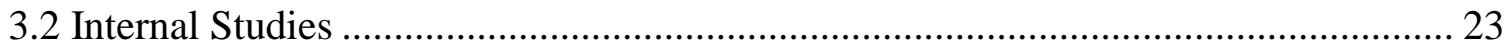

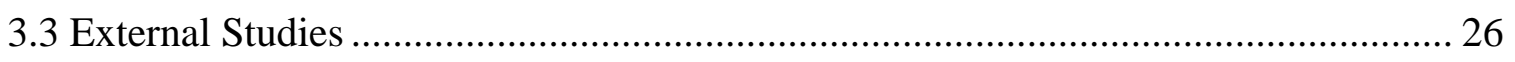

CHAPTER 4: METHODOLOGY OF THE STUDY ..................................................... 40

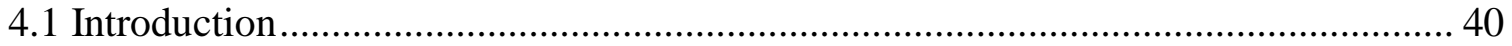

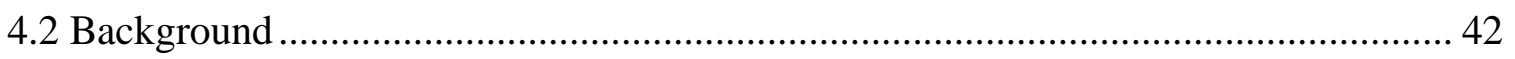

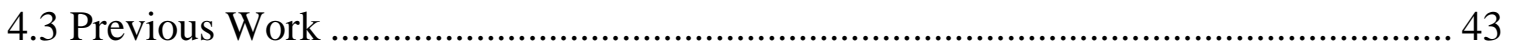

4.4 Imitation of the QIZ Model...................................................................................... 44 


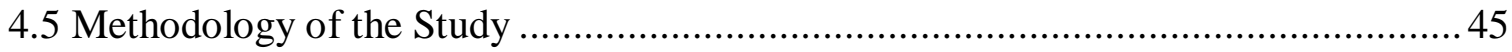

4.6 Outcomes from the Field Research ................................................................ 52

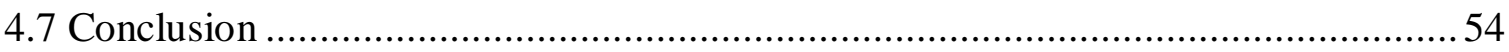

CHAPTER 5: THE SURVEY RESULTS ......................................................56

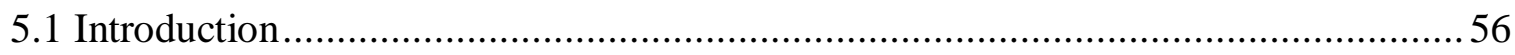

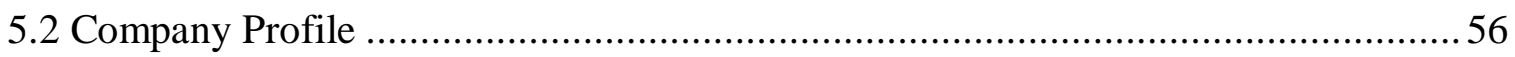

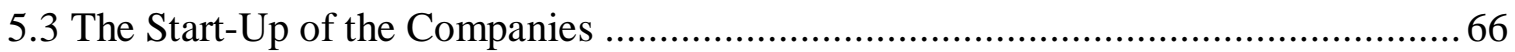

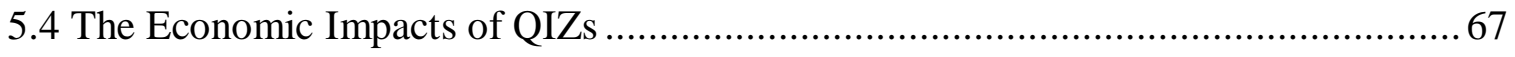

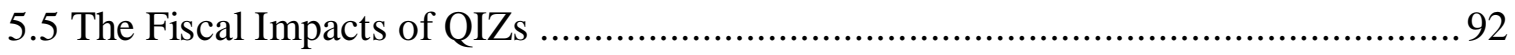

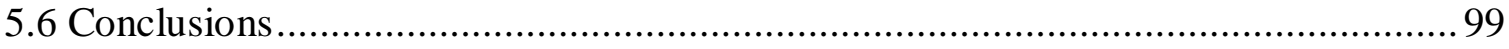

CHAPTER 6: QUANTITATIVE ANALYSIS OF THE SURVEY RESULTS ...... 104

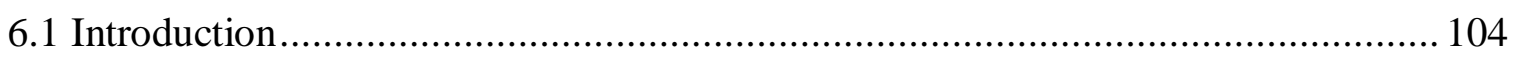

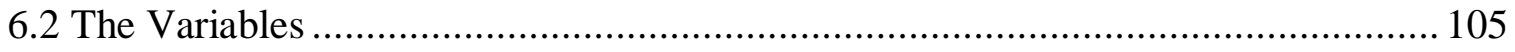

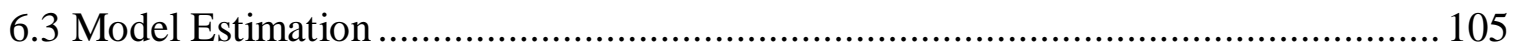

6.4 Model One: The Effects of QIZs on Economic Growth ...................................... 106

6.5 Model Two: The Effects of QIZs on Per Capita Income ..................................... 115

6.6 Model Three: The Effects of QIZs on Unemployment ..................................... 120

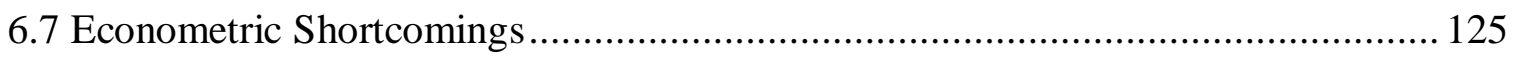

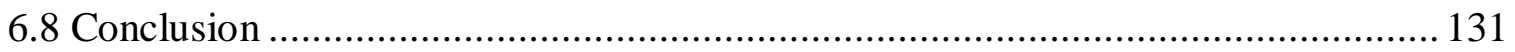

CHAPTER 7: POLITICAL ASSESSMENT AND PRUDENT PLANNING .........132

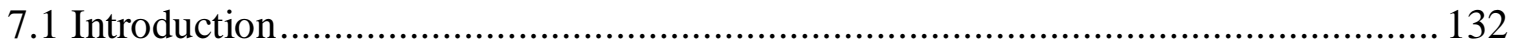

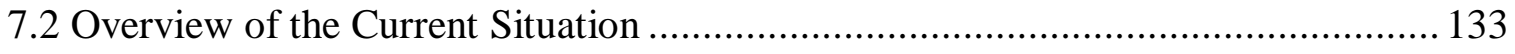

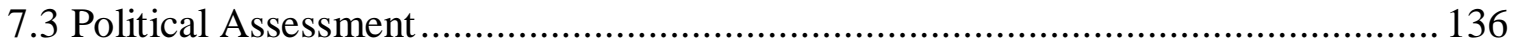

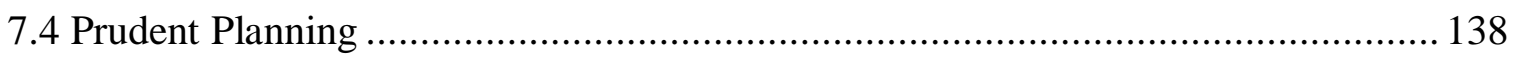

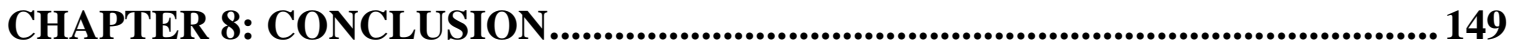

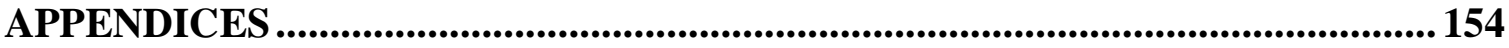

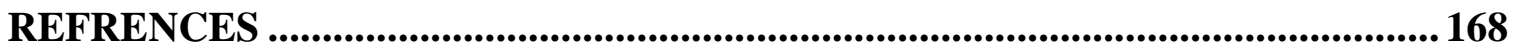

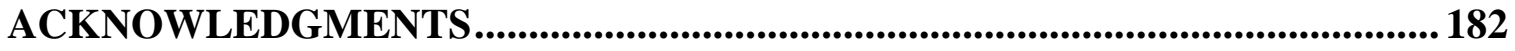

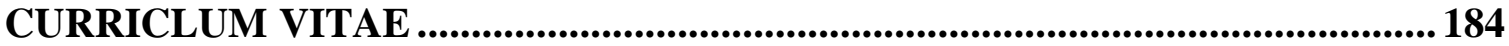




\section{LIST OF FIGURES}

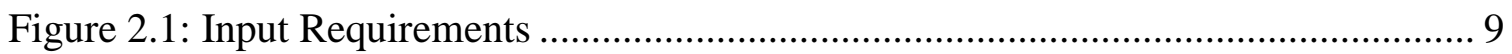

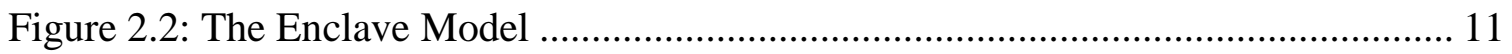

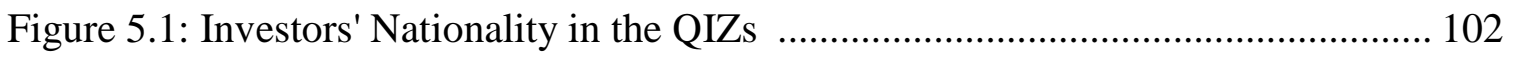

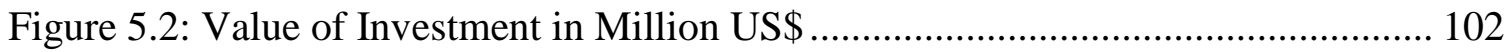

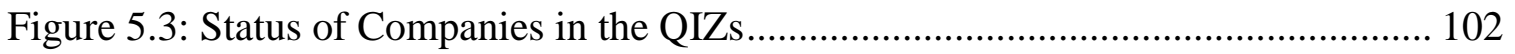

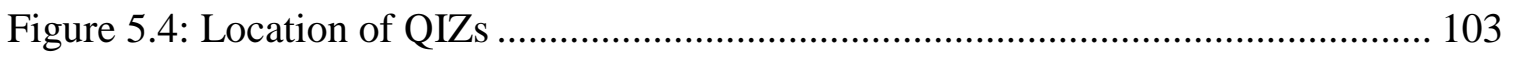

Figure 5.5: Share of Local and Foreign Employees in the QIZs ................................. 103

Figure 5.6: No. of Local and Foreign Employees in the QIZs .................................... 103

Figure 6.1: Growth Rate of Unemployment, Labor force

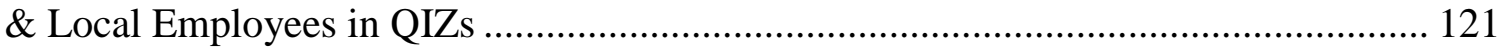




\section{LIST OF TABLES}

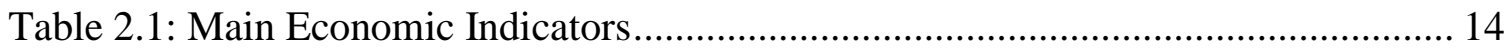

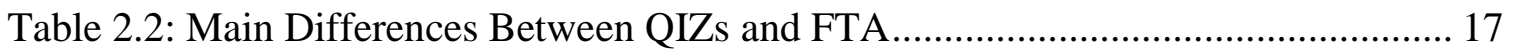

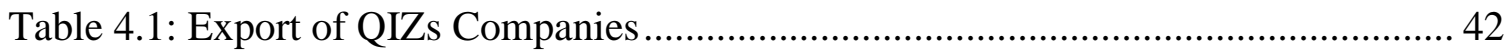

Table 4.2: Employment and Value of Investment in the QIZs ...................................... 43

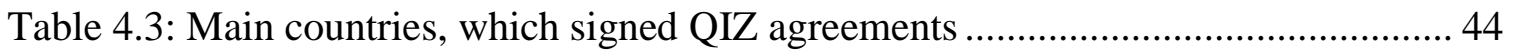

Table 4.4: Active QIZs According to Location, and No. of Companies ......................... 49

Table 4.5: Not Active and Under Construction QIZs ................................................... 49

Table 4.6: No. of Companies, Closed, and which Refused and Agreed to Fill the

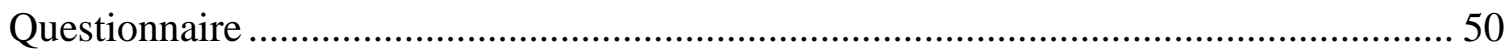

Table 4.7: Main Companies Which Found Closed During the Field Research................ 53

Table 4.8: No. of Subcontractor Companies According to Location .............................. 54

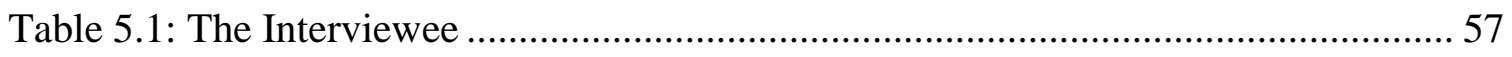

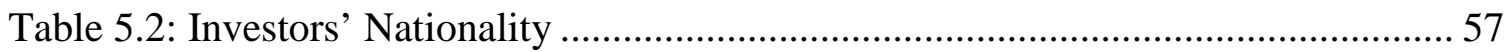

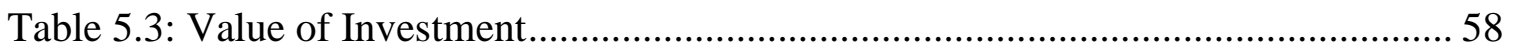

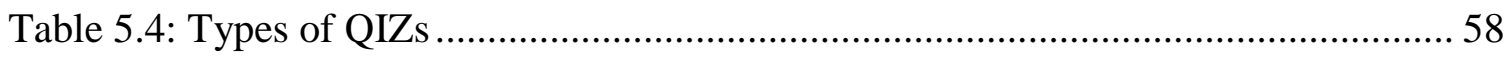

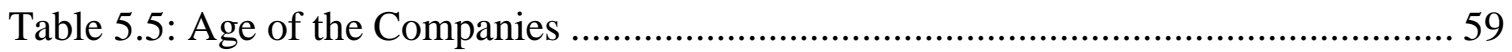

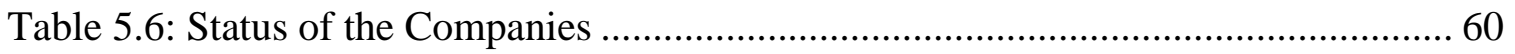

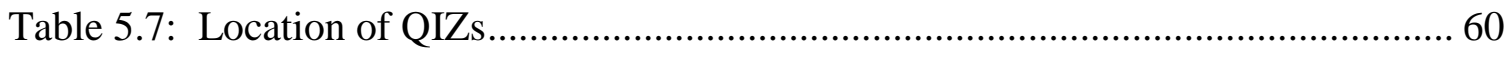

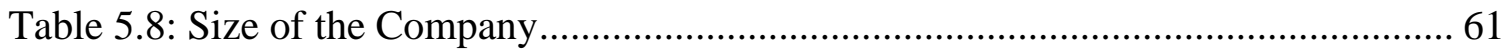

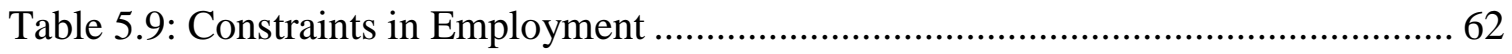

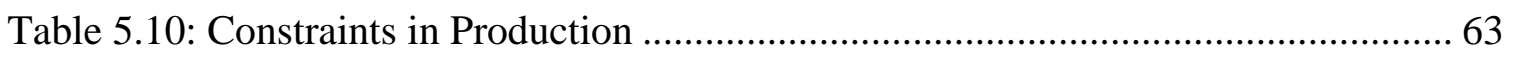

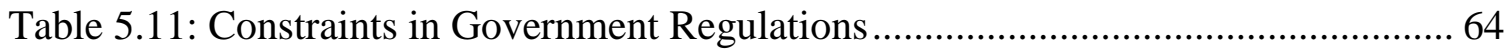

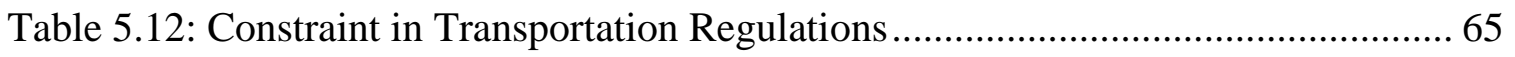

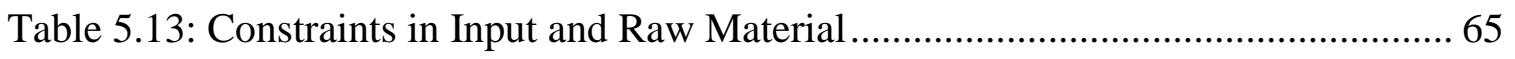

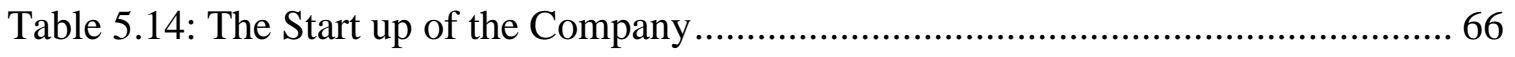

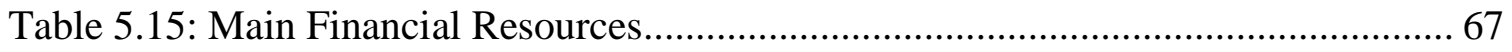

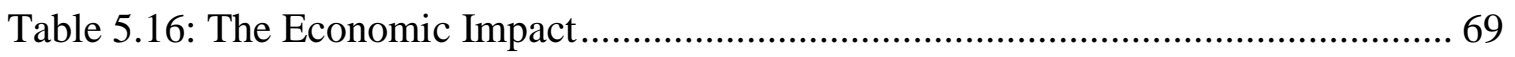

Table 5.17: Development of Labor Force and Unemployment 1999 - 2004................... 70

Table 5.18: Job Created by QIZs Companies ............................................................ 71

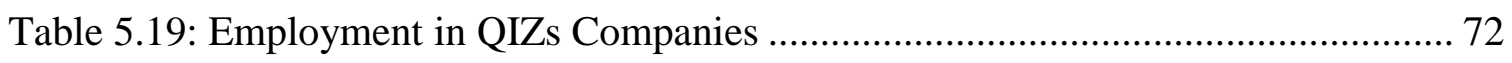




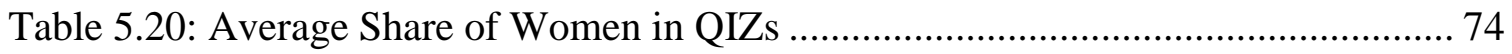

Table 5.21: Number of Skilled and Unskilled Employees in 2004 ................................ 75

Table 5.22: Wage Structure for Skilled and Unskilled Employees ................................ 76

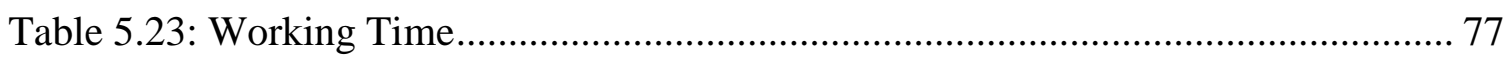

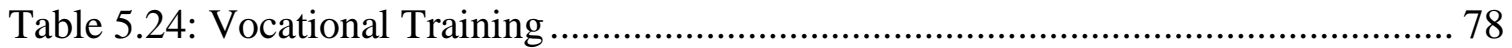

Table 5.25: Contribution of QIZs in Reducing Unemployment Rate............................. 79

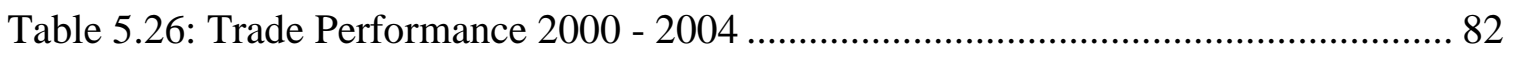

Table 5.27: Contribution of QIZs in Current Transfer .................................................. 84

Table 5.28: Cooperation Between QIZs and Local Companies .................................... 85

Table 5.29: Average Direct, Indirect, and Induced Effects of QIZ Companies ............... 86

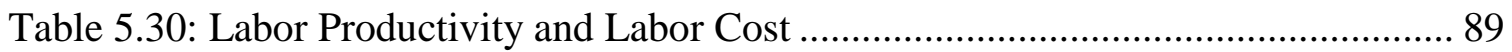

Table 5.31: Breakdown of the GDP Growth Rate Components .................................... 91

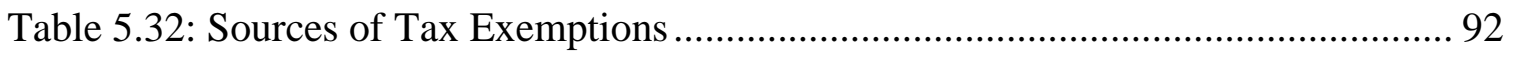

Table 5.33: Main Factors Affecting Investors’ Decision............................................. 96

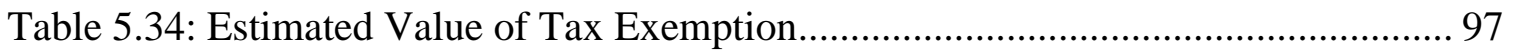

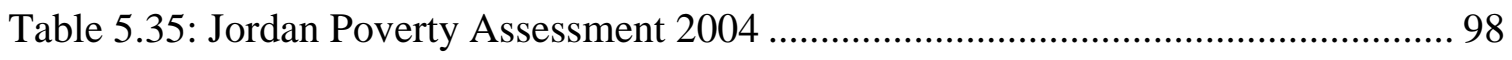

Table 6.1: ADF Test Result for Levels .................................................................... 112

Table 6.2: ADF Test Result for First Differences Series .......................................... 113

Table 6.3: Johansen Cointegrated Test (old) ............................................................ 113

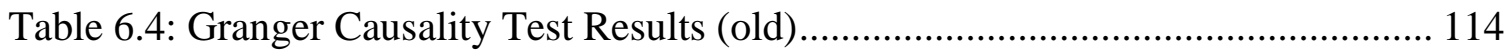

Table 6.5: Regression of Per Capita Income ............................................................. 118

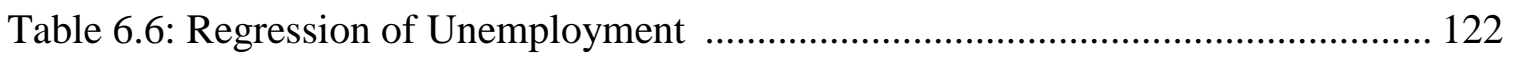

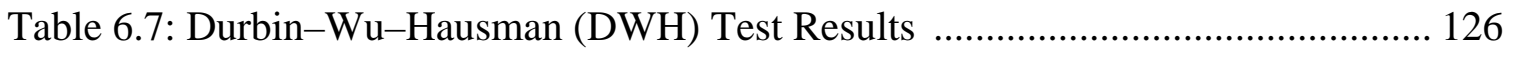

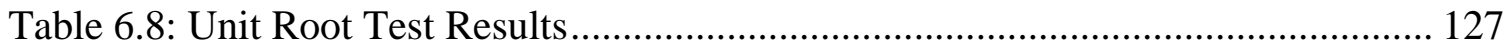

Table 6.9: Phillips-Perron Test for Unit root in First Differences Series ..................... 128

Table 6.10: Clemente-Montañés-Reyes Unit Root Test ............................................ 129

Table 6.11: Johansen Cointegration Test (new) ........................................................ 129

Table 6.12: Granger Causality Test Results (new) .................................................. 130

Table 7.1: External Trade of Jordan with Israel .......................................................... 134

Table 7.2: Employment and Value of Exports in the QIZs ......................................... 136 


\section{LIST OF APPENDICES}

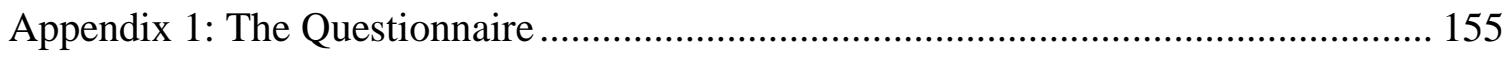

Appendix 2: Map of Active Qualifying Industrial Zones ........................................... 164

Appendix 3: Companies in the QIZs According to MIT Data ...................................... 165

Appendix 4: Companies in the QIZs According to Field Research.............................. 166

Appendix 5: Main Economic Indicators in Logarithms and Ratio ............................... 167 


\section{LIST OF ABBREVIATIONS}

$\begin{array}{ll}\text { AAEU } & \text { Association Agreement with the European Union } \\ \text { ASEZ } & \text { Aqaba Special Economic Zone } \\ \text { ATC } & \text { Agreement on Textiles and Clothing } \\ \text { DZ } & \text { Domestic Zone } \\ \text { EPZs } & \text { Export Processing Zones } \\ \text { EU } & \text { European Union } \\ \text { FDI } & \text { Foreign Direct Investment } \\ \text { FTA } & \text { Free Trade Agreement } \\ \text { FTZ } & \text { Free Trade Zone } \\ \text { GDP } & \text { Gross Domestic Product } \\ \text { GSP } & \text { Generalized System of Preferences } \\ \text { HS } & \text { Harmonized System } \\ \text { IFTA } & \text { Israeli-USA Free Trade Agreement } \\ \text { IMF } & \text { International Monetary Fund } \\ \text { ILO } & \text { International Labour Organization } \\ \text { LDCs } & \text { Least Developing Countries } \\ \text { MFA } & \text { Multi-Fiber Arrangement } \\ \text { MIT } & \text { Ministry of Industry and Trade } \\ \text { MOL } & \text { Ministry of Labour } \\ \text { MOP } & \text { Ministry of Planning and International Cooperation } \\ \text { NBC } & \text { Net Benefit-Cost } \\ \text { NPV } & \text { Net Present Value } \\ \text { QIZs } & \text { Qualified Industrial Zones } \\ \text { SEZs } & \text { Special Economic Zones } \\ \text { JFZ } & \text { Jordan Free Zone Corporation } \\ \text { Jinvestment Board }\end{array}$




$\begin{array}{ll}\text { JIEC } & \text { Jordan Industrial Estate Corporation } \\ \text { SMEs } & \text { Small and Medium Size Enterprises } \\ \text { UNDP } & \text { United Nations Development Program } \\ \text { UNCTAD } & \text { United Nations Conference on Trade and Development } \\ \text { USA } & \text { United States of America } \\ \text { US\$ } & \text { United States Dollar } \\ \text { USAID } & \text { United States Agency for International Development } \\ \text { WB } & \text { World Bank } \\ \text { WEPZA } & \text { World Export Processing Zones Association } \\ \text { WTO } & \text { World Trade Organization }\end{array}$




\section{CHAPTER 1}

\section{INTRODUCTION}

The Qualifying Industrial Zones (QIZs) established in Jordan were the first type of zones in the world. They were made possible by Jordan's peace treaty with Israel in 1994, which fostered a positive relationship among Jordan, Israel, and the USA.

During the Doha Summit in 1997, the three countries signed an agreement to promote economic cooperation and to support the peace process in the Middle East. An important part of the agreement was the establishment of QIZ in Jordan. These are industrial parks set up either in the Gaza Strip/West Bank, Israel, or Jordan. Goods produced in the zones can be exported to the USA duty-free. The QIZ in Jordan are export-processing enclaves that affirm the importance of fostering economic development and investment in the country.

Despite similarities to other export-processing zones in the world, the QIZ in Jordan operate under a unique set of conditions that distinguish them from the norm. These include: (a) products produced in QIZ are eligible for duty-free entry into the USA; (b) QIZ specifically encompass Jordan and Israel; (c) goods produced in the QIZ must fulfill a requirement that 35 percent of the value added from any combination of inputs must originate from Jordan QIZ, Israel, Gaza Strip/West Bank.

Specifically, goods produced in these zones must contain a minimum of Israeli content of 7 percent to 8 percent, and at least 11.7 percent of a product's content should be from Jordan. If these shares do not reach 35 percent, the remaining requirement must be reached by contributions from companies based in Gaza Strip/West Bank or the USA. The remaining 65 percent of product's content can be imported from anywhere in the world. 
The main goals for Jordan from establishing the QIZ can be summarized as follows: 1) to attract foreign direct investment; 2) to create job opportunities; 3) to accelerate export earnings; 4) to introduce advanced technology; 5) to enhance economic integration with Israel.

Companies operating in these zones have special conditions to meet to take advantage of the agreement. However, meeting these conditions enables products from these zones to be eligible for the same treatment as Israeli products have, according to the Israeli-USA Free Trade Agreement (IFTA), to allow duty-free entry to the USA market. As such, the 1997 agreement was an amendment to the IFTA signed in 1985.

The establishment of the first QIZ in Jordan was followed with great attention from all participants in the agreement to ensure that this venture would succeed. The potential political impact on the region was huge. Success would have meant strengthened relations between Israel and Jordan, and QIZ might then serve as a model for integrating other Arab countries.

Despite the interest of everyone involved, there have been few assessments of the impact of QIZ on the Jordanian economy. This study aims to fill this gap by analyzing the impact of these zones on the national economy, and the region as a whole, over the past eight years.

Economic data about the QIZ are impressive, but improvements in political relations are far less so. Between the years 1999 and 2004, exports from Jordan QIZs jumped from US\$ 2.4 million to US\$ 1.1 billion, thereby achieving an average annual increase of 340 percent during those years. Meanwhile, employment in QIZ topped thirty thousand employees. However, the political situation between Israel and Jordan is still unstable. No major progress has been made towards normalization between the two countries.

This study assesses the costs and benefits of establishing such zones in Jordan and evaluates whether these zones have achieved their goals. This evaluation will use costbenefit analysis to gauge the programs prospects for sustainability and expansion in the 
region. In particular, this study will explain the ways in which other countries can best make use of these types of zones.

The main discussions in this study concern the enormous benefits that will flow from the creation of meaningful QIZ, particularly the economic growth that would be stimulated in the country. In addition, an evaluation of the fiscal incentives offered to the investors under the Jordan Investment Board (JIB), the Jordan Free Zone Corporation (JFZC), and the Jordan Industrial Estate Corporation (JIEC). Also, this study explores the impacts of QIZ on the government's budget in ways that do not reflect its benefits on the economy and are considered, in some ways, as forgone revenue.

These issues - in particular, the issue of financial incentives - are characterized by their effects on the economy. These effects have different aspects, such one-sided generosity and ad hoc investment on the other side. If these come to fruition, the investment system that is now under force will attract footloose industry ${ }^{1}$. In addition to the above issues, this study aims to address the following questions:

1. Have the QIZ succeeded in achieving the primary goals for Jordan with regard to economic growth, export activity, foreign direct investment, unemployment, and foreign currency earning? If the answer is yes, how likely is it that these benefits will continue in the future?

2. Is it possible that increasing employment in such zones would support the general budget with additional funds? Is the number of new jobs created worth foregoing tax revenues?

This study assumes that there are potential benefits to the host country from establishing these zones. Under this assumption, this study will present the following hypotheses:

1. Establishing QIZ enhances employment opportunities, supports economic growth, and thus improves aggregate fiscal measures.

2. The benefits to the country of establishing this type of zone outweigh the losses associated with the fiscal incentives offered to the investors.

\footnotetext{
${ }^{1}$ Footloose industries are those that do not have economic reasons to locate either near the source of raw material or near to the market. Instead, they merely seek out cheap labor and move easily from one location to another.
} 
3. The QIZ participated and succeeded in developing the local export industry, created supporting industries, and thus benefited the national economy.

4. The development plan of the country concentrates on establishing QIZ as the only viable strategy to accelerate economic growth.

5. The QIZ strategy succeeded in achieving its goals with respect to political and economic progress.

This study will explore the fiscal and economic effects of QIZ on economies in general. Then it will detail Jordan's experience with the establishment of QIZ. As will be explained later, the QIZ program in Jordan follows political aims more than pursuing broad economic goals.

The study will be presented in the following way. Chapter 2 reviews the historical developments of the phenomena of QIZs in Jordan. This chapter includes descriptions of Jordan’s economic situation and its motivation to create the QIZs.

Chapter 3 goes through the exiting literature review of Free Economic Zones in Jordan and in the world. It then analyzes the effects of these zones on the economy to examine in how much these models can help evaluate the QIZ experience in Jordan, including the answers they offer and the limitations they have.

The descriptive analysis contained in Chapter 4 concentrates on the available data publicly and the empirical data obtained from field research. Chapter 5 and Chapter 6 show the results of using empirical analysis to assess the impact of QIZ on the Jordanian economy. This investigation uses both quantitative and qualitative methods to explore the data from field research.

Chapter 7 deals with assessment of the political situation, prudent planning and the future of QIZ under different potential scenarios it then gives policy recommendations for the QIZ. Chapter 8 concludes the study by bringing the various parts together to answer the leading research questions stated above. 


\section{CHAPTER 2}

\section{QUALIFYING INDUSTRIAL ZONES AND FREE ZONES}

\subsection{Introduction}

In the late 1960s and during the 1970s, most developing countries left the strategy of import substitution and adopted an export-led growth strategy. This is because import substitution strategy failed to achieve development requirements to these countries. Export-led growth strategy postulates that exports are the main channel through which free market process can affect the economic growth.

Therefore, when developing countries adapt the export-led growth strategy, geographical areas with special privileges and incentives emerge. These areas can be found all over the world, and are known by many different names, but with the same goals. These areas are known as Special Economic Zones (SEZs), Export Processing Zones (EPZs) and Free Economic Zones (FZs) ${ }^{2}$. These zones can be considered key instruments to create jobs, accelerate exports, increase foreign currency earnings, introduce advanced technology, and attract foreign direct investment. Experience of establishing these zones differ from one country to another: Ireland, Korea, China, and Taiwan were successful, while and unsuccessful countries include Kenya, Ghana, Zimbabwe and Zambia ${ }^{3}$.

The success story of Ireland in the 1960s is a prime example of the upside potential. In that case, the airport was turned into a duty free zone in order to attract foreign investors, which turned the country into a techno-economical industrial success story in the world ${ }^{4}$.

\footnotetext{
${ }^{2}$ Different types and names of export processing zones can be found in the world and serve the same goals, among them, free zones, industrial park, free trade zones and special economic zones.

${ }^{3}$ M. Tekere: Export Development and Export-led Growth Strategies: Export Processing Zones and the Strengthening of Sustainable Human Development.

${ }^{4}$ Behind the wire, (1996). World Export Processing Zone (WEPZA), can be found at http://www.wepza.org/
} 
According to the latest data from the International Labour Organization, there were about 3,000 EPZs and free trade zones operating in more than 100 countries in the year $2002^{5}$.

As in other countries, different types of free zones can be found in Jordan. The history of establishing FZs in Jordan starts in the 1970s when specific areas with special procedures and tax privileges were created. The main purpose is to enhance the economy of the country by attracting foreign investors. The experience of these zones does not differ much from the experience of other countries. Although hopes are always high, the ability to attract Foreign Direct Investment (FDI) is often limited. Instead, the zones end up concentrating on serving warehousing and transit trade with neighboring countries and the local economy.

\subsection{Definition of Free zones}

There are various definitions for the concept of FZs set by many international organizations, among others the definition of the United Nations Conference on Trade and Development (UNCTAD, 1973), the definition of the World Bank (WB, 1992), the definition of International Labour Organization (ILO, 1998), and the definition of the World Export Processing Zones Association (WEPZA). These definitions are similar in some ways and differ in others. Similar to the others, the definition of FZs given by WEPZA is very broad:

All government authorities' area such as, free ports, free trade zones, custom free zones, industrial free zones of foreign trade zones, or any other type of zone as the council may from time to time decide to include ${ }^{6}$.

\subsection{Definition of Qualifying Industrial Zones}

According to the President Clinton's Proclamation No. 6955 of 1996, the QIZs in Jordan are defined as:

\footnotetext{
${ }^{5}$ International Labour Organization (ILO) (2003), database on export processing zones.

${ }^{6}$ See article 1 of the status of WEPZA document for the (1978), can be found at http://www.wepza.org/
} 
Any area that encompasses portion of the territory of Israel and Jordan; has been designated by local authorities as an enclave where merchandise may enter USA without payment of duty or excise taxes; and has been specified by the President as a Qualifying Industrial Zone ${ }^{7}$.

The definition of QIZs is very similar to what is known now in the world as FZs, EPZs, Industrial Zones (IZs), and SEZs. For the purpose of this study we will use the concept of QIZs, especially related to Jordan. All other names for zones will be used only for clarification or comparison.

\subsection{Comparing Qualifying Industrial Zones and Free Zones}

There are many similarities and some differences between QIZs and other types of zones. The main similarities between these zones reflect the basis of the QIZs agreement. In spite of these zones being similar to each other, they differ slightly with respect to three main aspects: first, investors in the QIZs must meet specific rules of origin requirements from Jordan and Israel in order to produce and export to the USA market; second, in contrast to other types of Free Zones, QIZs are set up in order to strengthen the relation between countries (some other FZs also show this characteristic); third, Free Zones are generally established within a single country, while QIZs are established between several countries.

Moreover, the QIZs can be distinguished with respect to some criteria such as: (a) products produced in the zone are eligible for duty-free entry into the USA market, (b) the zones must encompass the territory of Jordan and Israel, and (c) products produced in the QIZs must fulfill 35 percent of the value added from any combination of inputs from Jordan QIZs, Israel, West Bank/Gaza strip.

As other types of zones in the world, QIZs can be used as an engine for growth and help to meet the national strategic objectives of the country. The main objectives for the QIZs to be achieved can be summarized as follows: 1) attract foreign direct investment, 2)

\footnotetext{
${ }^{7}$ For more details about QIZ agreement see Ministry of Industry and Trade website www.mit.gov.jo
} 
create job opportunities, 3) accelerate exports, 4) introduce advanced technology, and 5) enhance political and economic integration with Israel.

\subsection{The Idea of Qualifying Industrial Zones}

The idea of Qualifying Industrial Zones (QIZs) was offered to Jordan in 1996 from the USA. The QIZs agreement was signed at the economic conference in Doha/Qatar in November 1997 and came into effect in March 1998. This agreement defines the concept of the QIZs in Jordan, in which joint ventures between Israel and Jordan, if they comply with the criteria, can enjoy duty-free access to the USA market. However, the agreement was not exclusive; the USA extended similar agreements to other countries such as Egypt and sub-Saharan countries.

The idea of QIZs falls under the principle of 'rules of origin' which is frequently a key component of trade agreements. The rules of origin requirement is one of the main characteristics in the agreement between Israel, Jordan, and the USA. If these terms are met, the products of the QIZs are qualified for privileged access through USA customs. As such, the QIZs agreement between Israel and Jordan under the custody of the USA opens a window for cooperation between the two countries, both economically and politically.

According to the rules of origin, in order to qualify goods which are produced in a particular zone (say X), it is required to accumulate a particular percentage of production in this zone and in other zones. It is required that at least 35 percent of the added value of the product must be added in the QIZs. At least 11.7 percent should be from the Jordanian producer, 8 percent from Israel (7 percent for hi-tech products) and the remaining part should come from the United States or Gaza strip / West Bank. The reminder of 65 percent can come from any country. Figure 2.1 shows the main components of input requirements in the QIZs. 
Figure 2.1: Input Requirements

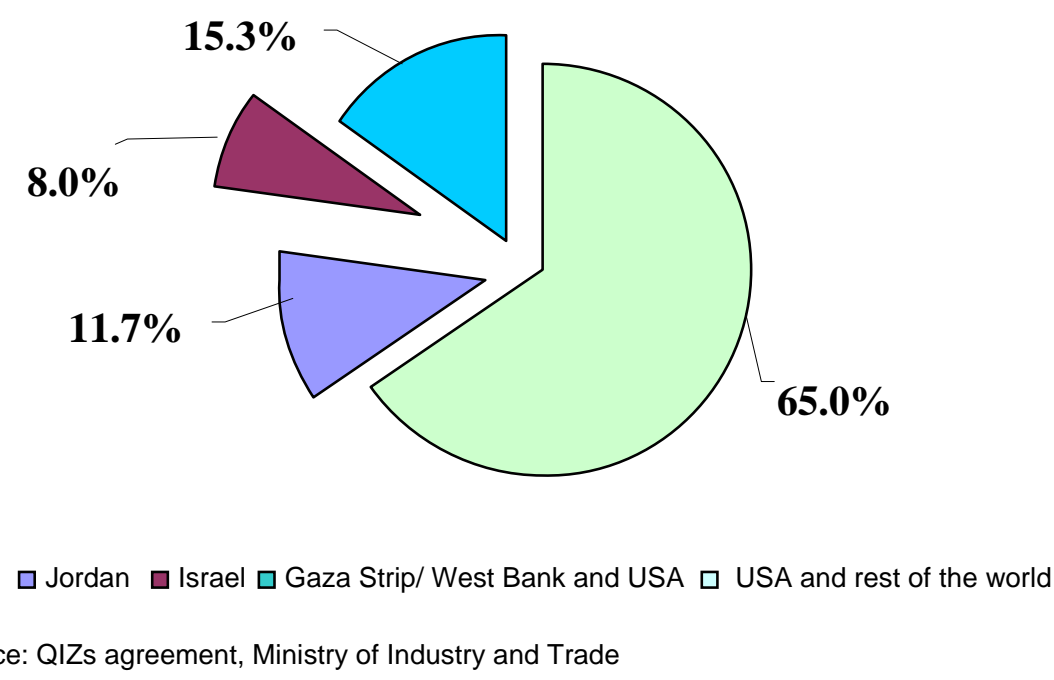

However, in addition to the option mentioned above, there are another two options to the companies for meeting the input requirements in QIZs: both the Jordanian and Israeli manufacturers must each contribute at least 20 percent of the total production cost of manufacturing goods in the QIZs. Production costs may include material, wages and salaries, design, $R \& D$, and depreciation of capital investment. Another option is a combination of the above mentioned requirements, with one partner providing at least 20 percent of the total production cost, while the other partner contributes the minimum content requirement as long as the total cost of production plus the cost of material makes up at least 35 percent of the appraised value of the product.

\subsection{The Enclave Model}

The QIZs in Jordan are industrial parks that operate as export processing enclaves. Such enclaves are created to foster economic development and investment in the region. In order to investigate the effects of the QIZs on the Jordanian economy, this analysis of the enclave model will be based on a cost-benefit analysis.

Warr (1989) constructs an enclave model to evaluate the cost-benefit analysis of establishing free zones in the host country. According to Warr, the flow of goods, services, and finances occur between the zones and both the rest of the world and the 
domestic economy. The essence of the enclave model is that the flows between the zones and the world are not relevant to evaluate of the welfare of the citizens of the host country. However, the enclave model is capable to evaluate the welfare impact if the flows occur between the relevant zone and the domestic economy.

The companies in the zones purchase intermediate and capital goods from abroad. These flows are accompanied by financial outflows in foreign currency. The company may also repatriate profits to mother companies abroad. Considering the case of the QIZs, the domestic economy provides infrastructure, utilities (e.g. electricity and water), and a local workforce. In return, the domestic economy receives jobs, wages, utilities tariffs, taxes, fees, and foreign currency earnings. In economic terms the net benefit-cost (NBC) for the QIZs in any year t can be expressed as:

$\mathrm{NBCt}=\left(\mathrm{W}-\mathrm{W}^{*}\right) \mathrm{Lt}+(\mathrm{LP}-\mathrm{OC}) \mathrm{Qt}+\mathrm{TFt}+$ Prot - Infracostt

where market wage and shadow wage refer to $\mathrm{W}$ and $\mathrm{W}^{*}$ respectively, Lt refers to number of workers. LP indicates domestic price of purchased input and the price of public utilities, while OC denotes to the opportunity cost of the domestic price of purchased input and the price of public utilities. Qt stands for units of domestic inputs, TFt for the payment of tariffs and fees by the companies, while Prot refers to the net profit to local shareholders. Infracostt indicates to the infrastructure cost of the zone and the operational cost provided by the country.

According to Warr, the costs are easily quantifiable, whereas it is more difficult to evaluate the benefits. Technology transfer and know-how are benefits to the host country, but are difficult to estimate. Generally speaking, there will be a benefit if the market wages exceed the social opportunity cost of employment in the zones. If average tariffs exceed the opportunity cost of supplying more power, and if the prices paid by companies for purchasing exceed the opportunity cost. Fees generated from the companies can be considered as a benefit to the country, because in the absence of these zones, these companies would be unlikely to work and pay fees.

The profit gains by companies from operating in these zones will not be considered in the calculation because the majority of the companies are connected with other mother 
companies, so that usually the profits are transferred outside the country. Only the amount of money needed to cover the payments of wages and the purchase of domestic inputs is exchanged into local currency. However, if the NBC is positive, the benefits from zones for the studied year exceeds the costs. In this case the zones can be considered efficient and the country can benefit from it. If a QIZ wants to be efficient, it is necessary that Net Present Value (NPV) should be larger than 0, the NPV can be written as:

$\mathrm{NPV}=\sum_{i}^{\mathrm{T}} \frac{\mathrm{NBCt}}{(1+\mathrm{r}) \mathrm{t}}$

Where r represents the shadow cost discount rate for the whole economy.

When applying the framework of the enclave model to assess the impact of QIZs on the economy we can recognize the following benefits and costs. Figure 2.2 depicts the effects of the enclave model on the domestic economy.

Figure 2.2: The Enclave Model

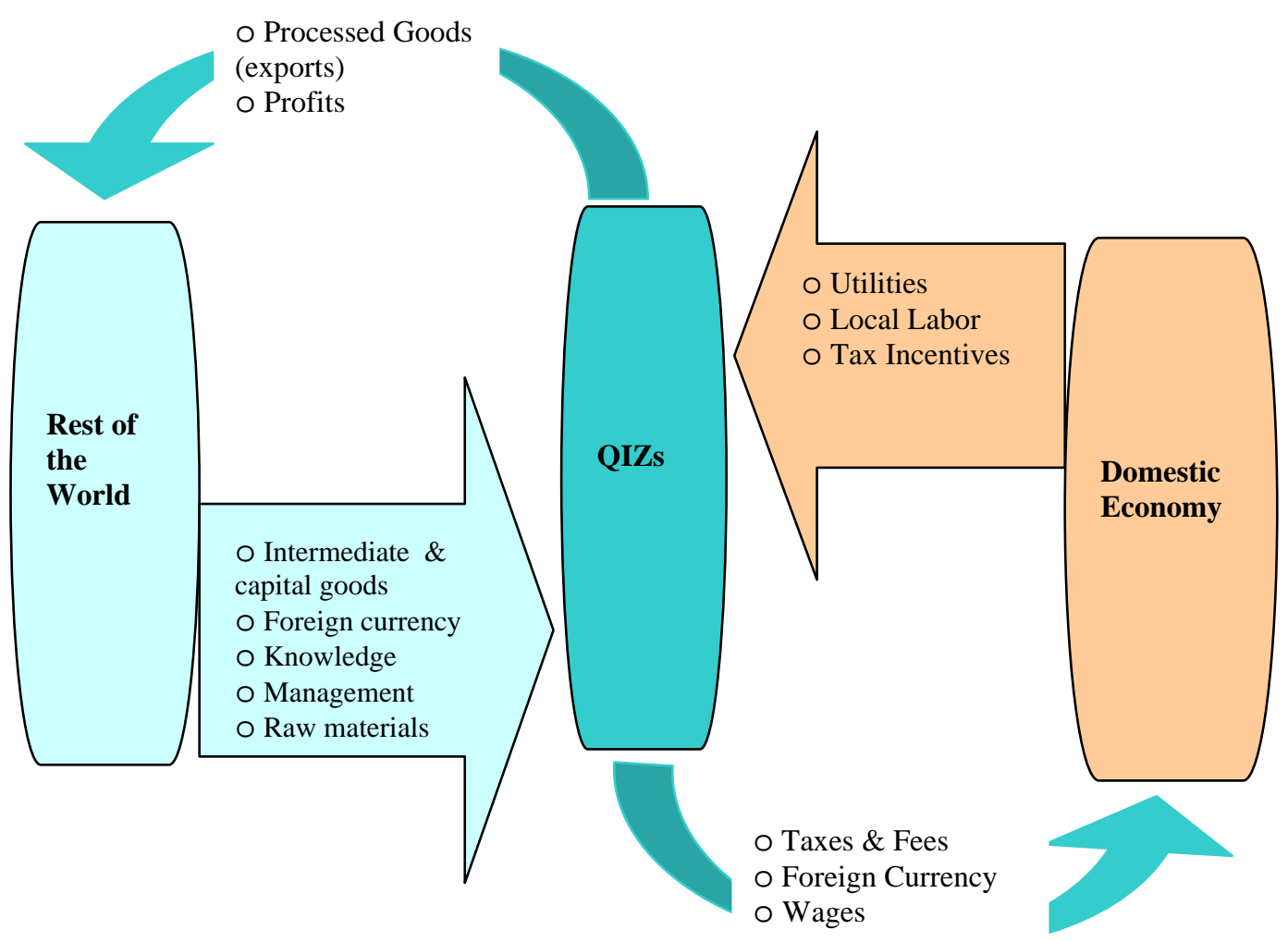


The analysis of the enclave model shows that QIZs are the main links between the domestic economy and the rest of the world. According to the enclave model the main channels that QIZs can affect the domestic economy throughout described as follows.

When countries set up zones, there is always a strong hope of attracting FDI, transfer technology, and new jobs. However, the experience of QIZs demonstrates that the technology transfer to the country due to the establishment of QIZs is very limited. The QIZs are generally too isolated from the domestic economy to make any potential backward and forward linkages. When companies start operating in the zones they assume that they will transfer foreign currency earnings, knowledge, and management to the local economy.

We can conclude from the enclave model the following benefits and costs: the enclave model shows that the QIZs companies operating in the zones employ both local and foreign employees; therefore, there are direct and indirect benefits to the domestic economy. Wages of local employees are spent locally, while wages of foreign employees are mainly transferred outside the country (apart from a certain amount that is spent locally). According to Jordanian labor law, the companies must obtain work permissions and pay fees for employing foreign employees.

The companies depend heavily on the domestic utilities such as electricity and water. In return, the company must pay tariffs for using these utilities, which benefits the economy. At the same time, using these scarce utilities can put pressure on the government to supply more of these utilities. This can be very costly because the Jordanian economy is heavily dependent on importing energy from neighboring countries. More consumption of energy increases the balance of payments burden. The companies operating in the zones assume to have their supply of domestic raw materials, but the experience of these zones shows that the purchase of domestic raw materials is very limited.

Regarding foreign currency earnings, the companies earn foreign currency by exporting goods. The companies convert foreign currency earnings into local currency, which in turn will be spent in wages and purchases from local economy. Given that QIZs rely on 
imported raw materials, the net impact on foreign currency from exports would be minimal.

Thus, foreign currency earnings have no direct effect on the economic welfare of the domestic economy. According to Warr, it would be incorrect to consider the foreign currency earning as a benefit to the host country because these funds may be treated as: 1) liquid form in foreign exchange account whether inside or outside the country, or 2) useful for the purchase of imported raw materials, or 3) convertible into domestic currency to be spent on wages and purchases from the local economy. In the first and second case the benefits to the host country are limited.

The most important effects of the foreign currency earning are the effects on the wages paid to local employees and the fees for work permissions for foreign workers. On the other side, it is incorrect to assume that the earnings from exports are earnings to the host country. Most companies operating in the zones are a branch of a mother company located outside the country and gain from exports and profits remain with these companies. But it must be realized that the zones have a ripple effects on the surrounding areas of the zones and lead to create focal service points to serve the companies and the employees.

Regarding taxes, QIZ-companies make little contribution to tax revenue, because these companies are exempted from paying taxes for the first 10 years. Only fees paid by the companies can be considered as a source of revenue to the budget. In the long run, the contribution of the companies to the tax revenue might increase if these companies continue working in these zones. On the other side, when the government decides to set up these zones, there is an infrastructural cost on the budget. For example the infrastructural costs of constructing QIZs in rural areas are especially high. The government develops these areas to attract investment and at the same time it grants tax exemptions and incentives to these zones. According to the enclave model the assumed benefits from the QIZs are the following:

o wages paid to local employees

o work permission fees of foreign workers by the companies 
o utilities tariffs for using electricity and water supplied from the domestic economy

o purchase of domestic raw materials

o foreign exchange earning

while the assumed costs are:

o infrastructure costs

o operational cost in the zones

o forgone revenue

\subsection{Jordan economy}

Jordan is a low-middle income country, with a per capita income of around US\$2,320 and a population of 5.5 million in 2005. Over the past three decades, Jordan benefited from the oil boom in the region. During this period, the Arab aid increased to Jordan. In 1980, the real economic growth registered 11.1 percent. But in the late 1980s, Arab aid and worker remittances decreased from the gulf area. Economic growth slowed down during the period 1988-1991 due to the financial crisis and the gulf war.

In 1992, Jordan continued implementing the structural reform program that started in 1989. Through the 1990s, the Jordanian economy registered a remarkable real growth rate, with an average annual growth rate of 4.3 percent. In spite of the regional uncertainty, Jordan's economy continued its good performance in 2005, with real GDP growth rate of 7.2 percent. This was driven by the efforts of a structural reform strategy that was adopted during the last decade, particularly on the fiscal and monetary side, privatization, and opening the economy to the international market. Table 2.1 shows the development of the main economic indicators during the last years.

Table 2.1: Main Economic Indicators in percentage (\%)

\begin{tabular}{|l|c|c|c|c|c|c||}
\hline & $\mathbf{1 9 8 0}$ & $\mathbf{1 9 8 5}$ & $\mathbf{1 9 9 0}$ & $\mathbf{1 9 9 5}$ & $\mathbf{2 0 0 0}$ & $\mathbf{2 0 0 5}$ \\
\hline Real GDP & 11,1 & $-2,7$ & $-0,3$ & 6,2 & 4,1 & 7,2 \\
\hline Total Exports & 39,9 & 6,9 & 10,7 & 24,7 & 3,7 & 10,8 \\
\hline Domestic Exports & 45,5 & $-2,2$ & 14,6 & 26,5 & 2,8 & 11,4 \\
\hline Imports & 22,2 & 0,3 & 40,3 & 9,6 & 23,7 & 28,3 \\
\hline QIZs Export & - & - & - & - & 945,8 & 9,9 \\
\hline
\end{tabular}




\subsection{External Sector Performance}

Jordan suffers from a chronic trade deficit resulting mainly from its modest resource and production bases and high consumption patterns. Imports have historically been two to three times higher than domestic exports. Between 1980 and 2004 share of domestic exports to imports increased from 17 percent to 40.5 percent. The trade deficit registered average annual growth around 10 percent over the period from 1980 to 2004, which indicates the dependency on the rest of the world of Jordan's consumption.

\subsubsection{Exports}

Domestic exports recorded strong growth during the period 1980-2004, with an average annual growth rate of 16 percent. The remarkable growth of domestic exports was due to such things as (1) the role of the government to encourage exports, (2) the role of the private sector in boosting exports by penetrating new markets, (3) the improved competitiveness of Jordanian products abroad, (4) the export led growth strategy which was adopted in the late 1980s, (5) the exchange rate regime, which was followed in the late 1990s, and (6) free market policy and liberalization of the economy.

One of the government tools is export-led growth; throughout this strategy export performance continues to drive the economy forward. Available data shows that total exports (domestic exports plus re-exports) increased in 2004 by 26 percent compared to a growth of 11.3 percent in 2003. The increase of the total exports resulted from an increase of the domestic exports by 37.7 percent in 2004, compared with 7.6 in 2003 and decreasing of re-export by 12.4 percent in 2004.

One source of the good performance of exports in the recent years was led by a QIZs initiative which helps to increase the Jordanian exports to the USA market. Latest data shows that export from QIZs increased in value from US\$2.4 million in 2000 to US\$ 586.6 million in 2003 and continues to increase in 2004 until it reached US\$ 1121.2 million and composed around 34.5 percent from the domestic exports. 


\subsubsection{Imports}

Jordan's imports steadily increased at an average annual rate of 10.7 percent during the period 1980-2004. the increase in imports was due largely to the increase in world prices, and the reduction of import tariffs one of Jordan's major imports.

Latest data shows that imports of raw materials, intermediate goods and capital goods excluding oil and fuel imports consist of about 54 percent on average of total imports during the same period. Imports recorded around 13.1 percent growth in 2003 and another 41.5 percent in 2004. On the other hand such high growth of imports resulted mainly from an increase in oil, machinery, and transport equipment following the reduction of custom duties on imports of raw materials and intermediate goods.

\subsection{Jordan's Foreign Trade Policy}

Jordan's trade policy is based on openness and integration with the world economy. During the past years, Jordan reacted to the changes in world economy by liberalizing its economy. It adopted open door policies and an export-led strategy, signed many trade agreements with other countries, and set up free trade zones.

In addition to the QIZ agreement in 1997, the most important trade agreements that Jordan signed are the ones with the World Trade Organization (WTO) in 2000, the European Association in 2000, and the Free Trade Agreement with the USA in 2000. These agreements were assumed to create a healthy investment climate in the country, increase exports, and attract foreign direct investment.

By adopting this trade policy, Jordan sought to use these as an engine for growth to improve Jordanians welfare and standards of living. However, with the entrance of other developing countries into similar trade agreements, the Jordanian economy had to face many challenges, particularly concerning the industrial exports sector. As a result, competition increased between the Jordanian export market and the export markets of China, Pakistan, and Egypt. The following are brief descriptions of these major free trade agreements. 


\subsubsection{The USA - Jordan Free Trade Agreement}

The USA-Jordan Free Trade Agreement (FTA), signed on October 24, 2000, searches to eliminate duties and commercial barriers to bilateral trade in goods and services between Jordan and the United States. The FTA also includes separate sets of substantive provisions concerning trade and the environment, trade and labor, and electronic commerce. Other provisions concern intellectual property rights protection, balance of payments, rules of origin, safeguards, and procedural matters such as consultations and dispute settlement.

Under the FTA, tariffs will be eliminated on virtually all trade between the two countries within 10 years. Tariff reductions will occur in four stages: (i) current tariffs of less than 5 percent will be phased out in two years, (ii) those that are now between and 5 and 10 percent will be eliminated in four years, (iii) those between 10 and 20 percent will be gone in five years, and (iv) those that are now more than 20 percent will be eliminated in 10 years. The following table highlights the main differences between the QIZs and the FTA.

Table 2.2: Main differences between QIZs and FTA

\begin{tabular}{|l|l|l|}
\hline & \multicolumn{1}{|c|}{ QIZ } & \multicolumn{1}{|c|}{ FTA } \\
\hline Duty and Quota-Free Status & Exported goods are duty free & $\begin{array}{l}\text { Schedule of elimination of } \\
\text { duties gradually over 10 years }\end{array}$ \\
\hline Activities Covered & $\begin{array}{l}\text { Only industrial activities are } \\
\text { covered }\end{array}$ & $\begin{array}{l}\text { Industrial activities and } \\
\text { services would be covered }\end{array}$ \\
\hline Legal Framework & $\begin{array}{l}\text { Jordanian goods are exported } \\
\text { to the US in accordance with } \\
\text { the FTA between the US and } \\
\text { Israel }\end{array}$ & $\begin{array}{l}\text { Jordanian goods will be } \\
\text { exported to the US in } \\
\text { accordance with the direct } \\
\text { FTA between the US and } \\
\text { Jordan }\end{array}$ \\
\hline Designated areas & $\begin{array}{l}\text { Defined areas within the } \\
\text { country Jordan }\end{array}$ & $\begin{array}{l}\text { Jordan as a whole regarded as } \\
\text { a free zone }\end{array}$ \\
\hline Input Requirements & $\begin{array}{l}\text { - Production of goods subject } \\
\text { to (7- 8\%) Israeli input } \\
\text { - 11.7 \% Jordanian Input } \\
\text { Requirements }\end{array}$ & $\begin{array}{l}\text { Now percentage set up until } \\
\text { now 35\% Jordanian under current } \\
\text { negotiations }\end{array}$ \\
\hline
\end{tabular}

Source: QIZ and FTA agreement, Ministry of Industry and Trade 


\subsubsection{The Euro-Mediterranean Association Agreement}

The Euro-Mediterranean Association Agreement aims to create a new climate for economic and cultural relations, in particular for the development of trade, investment, and economic and technological cooperation. Under this agreement, free trade will be achieved in 12 years. The Agreement also covers services, social and cultural affairs, and financial co-operation. All industrial products and natural resources originating in Jordan would enter duty free in the European Union (EU) immediately, while EU industrial products benefit from annual duty reductions over the 12-year implementation period.

Under this Association Agreement with the European Union (AAEU), products originating in the EU are excluded from preferential treatment, and specific import procedures and safeguards are made up for trade in agricultural products. About 65 percent of the goods imported from the EU will receive preferential treatment, excluding some products, including cigarettes, used cars, tomato paste, used clothes, clothes and shoes, furniture, and carpets. With respect to services, there is no schedule of specific commitments beyond those made under the WTO commitments.

\subsubsection{WTO Accession and Commitments}

Jordan became a member of the WTO in April 2000. In addition to liberalizing trade for goods and services, Jordan committed itself to comply with the WTO Multilateral Agreements on Trade Related Aspects of Intellectual Property Rights (TRIPS), Customs Valuation, Import Licensing Procedures, Technical Barriers to Trade, and Sanitary Measures.

Tariffs are to be bound at a 20 percent ceiling by the year 2010, with the exception of certain items that are to be bound at a 35 percent level. Jordan's tariff schedule has six ad valorem rates: 0 percent, 5 percent, 10 percent, 20 percent, 30 percent and 35 percent. Tariff reductions will be implemented in March of every year. In services, Jordan's commitments covered the majority of the services sectors. From a total of 155 subsectors, classified within 12 sectors, Jordan made commitments to 128 sub-sectors until now. 


\subsection{Free Trade Zones in Jordan}

Jordan has different kinds of free trade zones spread across the country. The establishment of these zones started in the 1970s and continued in the 1980s with the creation of the industrial estates corporation. However, in the 1990s the government established the Qualifying Industrial Zones in 1998 and Aqaba Special Economic Zone in 2001. The experience of these zones differs, but all were aimed at attracting foreign direct investment to achieve the development strategy of the country. There are four kinds of free zones in Jordan. The following is a summary of these different zones and their role in the development strategy of the country.

\subsubsection{Public Free Zones}

Public free zones can be defined as a zone where investment is administered by the free zones corporation. During the 1970s, Jordan set up the first free zones near the Aqaba port. Other free zones were set up later in different locations in the country, including Zarqa, Irbid, and Amman governorates. According to the free zone corporation law, the main reasons behind establishing these zones in the country were to achieve the following: 1) encourage export oriented industry, 2) serve the transit trade between Jordan and neighboring countries, 3) attract foreign direct investment, and 3) serve as warehousing and storing place for different kinds of goods.

Companies operating under the free zone law can benefit from the following package of incentives: i) exemption of profits from income tax for a period of twelve years, ii) exemption of non-Jordanian employees from income tax on their remuneration and from the social service tax, iii) exemption of goods imported into or exported from free zones from customs duties, import fees and any other fees and taxes, iv) exemption of lands, buildings and properties in free zones from licensing fees and taxes, v) freedom to repatriate capital investment and profits earned, subject to prevailing laws and regulations. 
Both Jordanian and foreign investors are permitted to invest in trade, services, and industrial projects in free zones. Industrial projects must have the following characteristics:

(a) New industries depending on advanced technology,

(b) Industries requiring local raw materials and/or locally manufactured parts ,

(c) Industries complementing domestic industries,

(d) Industries enhancing labor skills and promoting technical know-how, and

(e) Industries providing consumer goods and reducing the dependency on imports.

More than 20 years passed, the role of these zones on the economy is low both absolutely and especially when comparing to other types of zones. The available data for the Jordanian free zones during the period 1974 - 1997 and its impact on the economy is shown in the following 8

o The main dominant sectors in the free zones were trade for storage purposes, service, and industry. The trade and services sector consists of around 84.3 percent of private investment, while the industry sector consists of around 9.5 percent of private investment.

o The total expenditure for establishing the free zone during the above mentioned period amounts to around US\$ 39.5 Million. This amount was spent on the infrastructure and on expanding other free zones in Aqaba and Zarqa.

o The relative importance of the revenue from the free zone as a share of GDP does not exceed 0.1 percent at an annual basis during the above mentioned period.

o By the end of the year 1993 the number of investors in the trade, industrial sector and cars exhibitions reached 527, 25, and 125 respectively.

\footnotetext{
${ }^{8}$ Al Arda, F. S., and Sahawneh, M. N. (1996). Free Zones in Jordan: Facts and Outlooks, the Royal Scientific Society, Amman.
} 
o The dominant nationality of investors in the free zone is Jordanian and consists of around 81 percent of the total investor while foreign investors do not exceed 19 percent.

According to the results above, the relative impact of this kind of zone on the economy concerning foreign direct investment, employment, technology transfer, and foreign currency earnings is weak. The free zone neither transforms the country into an industrial park, nor does it keep pace with the changes in the regional and global economies ${ }^{9}$.

\subsubsection{Private Free Zones}

Private free zones have generated greater economic benefits than the traditional public free zones in almost all respects. Private free zones are defined as zones which are administered by the private sector under the supervision of the Free Zone Corporation. In 1991, the Jordanian government approved the establishment of privately owned free zones to activate the private sector in economic development. There are currently nine privately owned free zones operating in Jordan, four of which are industrial free zones and the others are multi-purpose zones. The total capital in those zones is estimated at US\$ 1180 Million in 2005. This figure represents about 90 percent of the total investment in the current public and privately owned free zones. This reflects the important role played by those zones in activating Jordan’s industrial strategy and foreign trade.

Latest data about private free zones in Jordan shows that there were about 22 companies employed around 4,000 local employees.

\subsection{Industrial Estates}

The first industrial estate was established in the 1980s under the name of Sahab Industrial Estate. It is considered a semi-governmental corporation with the participation of public and private sectors. The aim of establishing this industrial estate was to support and

\footnotetext{
${ }^{9}$ Al Khouri, R. (2001). Qualifying Industrial Zones as a Model for Industrial Development: Case of Jordan and its Implications for the Region, Friedrich-Elbert Stiftung, Amman office, can be found in www.fes-jordan.org, December.
} 
encourage the industrial sector and attract foreign direct investment. In 1991, the second industrial estate was established with the name of Al Hassan Industrial estates in Irbid governorate. In the late 1990s, the third industrial estate is established in Karak governorate. In addition to achieving its goals, the Industrial Estates managed to establish new QIZs in the country.

\subsection{Aqaba Special Economic Zone}

The Aqaba Special Economic Zone (ASEZ) was established in 2001 as a liberalized, lowtax, and duty-free zone. It was designed to attract and serve foreign and local investors. The objective of the ASEZ is to transform the underdeveloped Aqaba region. It is to be an engine of economic growth in Southern Jordan via the introduction of a modern, efficient, simplified business environment to attract investment and increase private sector participation. In the ASEZ, the private sector is involved in the development of transportation and communication services, tourism, and high value-added activities. Despite that this zone is still new, it seems to continually improve and attract investors.

\section{Conclusion}

This chapter deals with the development of EPZs and QIZs, with particular focus on Jordan. Experience of establishing EPZs differs from one country to another, which is reflected in its success in some countries and failure in others. The history of establishing FZs in Jordan began in the 1970s by establishing areas with special procedures and tax privileges. The experience of these zones does not differ much from the experience of other countries. As such, attracting FDI was limited and instead it served the purpose of concentrating to serve warehouse and transit trade with neighboring countries and the local economy. 


\section{CHAPTER 3}

\section{LITERATURE REVIEW}

\subsection{Introduction}

In this chapter, we will review the main literature that deals with the concept of the Qualifying Industrial Zones (QIZs) in order to assess their welfare impact on the economy. When trying to search for the available literature on the welfare effects of the QIZs we found only a few studies dealing with this type of zones due to their "newness" in the world and particularly in Jordan. The vast majority of literature was found to be on other types of zones such as free economic zones and special economic zones. However, we will start our analysis by reviewing the available literature, which evaluates the welfare effects of these zones. Although the literature does not cover all criteria of the QIZs, it lays the ground for the analysis of QIZs. Therefore, this chapter will deal with two kinds of literature reviews. The first part will deal with internal studies that assess the experience of Free Zones (FZs) and QIZs in Jordan, while the second part will discuss external studies that are used to evaluate other types of zones in the world.

\subsection{Internal Studies}

There are only a few studies investigating the impact of QIZs and FZs on the Jordanian economy. Those studies show the main advantages of the establishment of these zones with respect to export and employment. Among these studies are e.g. Al Khouri, (2001), Gaffney, (2005); Kardoosh, M., (2004), Manneh, (2003), Okasheh, B., (1996), and Sammour, E., (1995).

For instance, Al Khouri (2001) found that the economic benefits for establishing QIZs were particularly from employment creation. In addition, he considers these zones as a model for the industrial development and it will be a solution for the unemployment problem in the country. Gaffney (2005) on the other hand draws a pessimistic view about the future of QIZs in the country despite their various positive effects, such as the cultural 
changes and the increase in exports and employment. While Manneh (2003) indicates the importance of these zones to the country regarding employment and foreign currency earning, Kardoosh (2004) shows some of the negative consequences that the zones had, such as the uncertainty of continuing these zones in the future. Following is a brief summary of the main internal studies that evaluate both FZs and QIZs in Jordan:

\section{Enass E. Sammour, (1995): Jordan Free Zones, Study in Geography of Development ${ }^{10}$.}

The study reviews the development of establishing the free zones in Jordan and examines the characteristics of investment and investors. It then evaluates the administration system and the employment operating in those zones in order to determine what kind of problems they face to give solutions and recommendation. It also concentrates on the geographical distribution of exports and imports to trace the effects of economic and political effects on FZs. In the end, the study introduces recommendations such as the use of information technology, a marketing strategy for the FZs and proposes diversity of markets for the exports of zones.

2. Bilal Okasheh, (1996): Evaluation of Jordanian Free Zones Experience ${ }^{11}$.

The aim of this study is to analyze and evaluate the economic impact of establishing Free Zones. It then describes the experience of establishing these kinds of zones and the main objectives behind them. The study ends with a number of recommendations and conclusions, the most important were: 1) the need for amendment of laws and regulations, 2) the need for making customs procedures easier (eliminating red-tape) for the entrance of raw material, and 3) the need for establishing vocational training centers for the employees.

3. Al Khouri, R., (2001): Qualifying Industrial Zones as a Model for Industrial Development: the Case of Jordan and its Implications for the Middle East Region ${ }^{12}$.

This study investigates the reasons for establishing the Free Zones (FZs) by countries in the Middle East region. It provides a comprehensive description of the establishment of

10 Sammour, E. (1995). Jordan Free Zones, Study in Geography of Development, Master thesis, University of Jordan. 11 Okasheh, B., (1996). Evaluation of Jordanian Free Zones Experience, Master thesis, University of Jordan.

12 Al Khouri, R., (2001). Qualifying Industrial Zones as a Model for Industrial Development: Case of Jordan and its Implications for the Region, Friedrich-Elbert Stiftung, Amman office, can be found in www.fes-jordan.org, December. 
the FZs in Jordan as well as in other countries in the region. It then compares between the impact of FZs and QIZs and finds that establishing the QIZs are more benefit to the country from establishing the FZs. In the end, the study shows that political consequences played a big role in the establishment of QIZs in Jordan and recommend other countries in the region to follow Jordan in establishing this kind of zones.

\section{Manneh, (2003): Qualifying Industrial Zones in Jordan ${ }^{13}$.}

This study describes the establishment of the QIZs in the country and analyses the characteristics of companies investing in the QIZs. The study highlights the importance of these zones to the country regarding employment and foreign currency earning. In order to maintain the QIZs in the country, the study gives future recommendations to the companies. It is shown that the survival and growth of QIZs is heavily dependent on the diversification of their industries as well as on the development of high quality products.

5. Kardoosh, (2004): Qualifying Industrial Zones and the Jordanian Quest for Sustainable Development $^{14}$.

This study investigates the development of the QIZs and their impact on employment, export and investment. It then shows a negative outlook about the zones, such as the uncertainty of continuing these zones in the future and the limitation in creating backward linkages and technology transfers with the domestic economy. The study concludes that the need to maintain these zones in the future depends on the decision of the USA customs as to whether they should continue to impose high duties and taxes on apparel and garment. In addition, the study shows the importance of diversification export markets in the future.

\section{Gaffney, (2005): Jordan’s Qualified Industrial Zones: A Qualified Success? ${ }^{15}$}

This study examines the characteristic of the QIZs from different aspects. It analyzes the establishment of these zones and their impact on the country. The study found that on the economic side there are some good achievements while on the political side the situation is faltered. In the end, the study draws a pessimistic view about the future of QIZs in the

13 Manneh, J., (2003). Qualifying Industrial Zones, Sector Report, research and studies, Export Finance Bank.

14 Kardoosh, M., (2004). Qualifying Industrial Zones and the Jordanian Quest for Sustainable Development, the Jordanian Center for Public Policy Research and Dialogue.

15 Gaffney, J., (2005). Jordan's Qualified Industrial Zones: a Qualified Success? Master Thesis, University of Pennsylvania, USA. 
country despite their positive effects on the country from different aspects such as the cultural changes and an increase in exports and employment.

7. Jordan Garment, Accessories \& Textiles Exporter' Association (JGate), (2005): Sustaining Jordan's Competitive Edge ${ }^{16}$.

This study compares the difference between the QIZs agreement in Egypt and Jordan and the investment incentives offered to the investors within the two countries. The study shows that there are many risks surrounding the QIZs in Jordan compared to the ones in Egypt. These risks concern the minimizing of production costs. In order to maintain Jordan's competitive advantage in the future, the study recommends applying the following: a) The elimination of bank guarantees on raw materials, b) The minimizing of transportation costs, c) Reducing the costs of public utilities (water, sewage and electricity), d) enhancement of the industry sector by eliminating red tape, e) improvement of Aqaba port, f) increasing number of local workforce, and f) the acceleration of the Jordan-US free trade agreement.

\subsection{External Studies}

There are various studies about the costs and benefits of free zones on the host country. Some of these studies examine the costs and benefits of these zones from a theoretical point of view, and found positive effects to the host country from establishing FZs. Other studies used empirical data to estimate the effects of these zones on the host country. According to the theoretical studies, Hamada (1974) was the first pioneer in studying the role of Free Zones on the welfare of the country. His findings show a negative impact on the host country from establishing Free Zones. Following Hamada's result, researchers started to investigate more Hamada's findings, e.g. Rodriguez (1976) and Hamilton and Svensson (1982). Other studies conducted by Warr (1989), Madani (1998), McKenney (1993), Mireri (2000), Tekere (2000), UNCTAD (1973), UNIDO (1980), Jallab and Armas (2002), Sinclair (2001), and International confederation of Free Trade Unions (2003) investigated the effects of FZs from empirical point of view. Out of those two groups of thought, a third group appeared, but could not prove if FZs are beneficial or

16 Jordan Garment, Accessories \& Textiles Exporter’ Association (JGate), 2005; Sustaining Jordan’s Competitive Edge 
costly to the country, e.g. Oborne, (1986), Tsui, (1993), Cling and Letilly, (2001), McKenney, (1993), and Jayanthakumaran, (2003).

However, the literature review reveals that there are no agreements on the effects of the FZs on the host country. For instance in his study, Hamada used a standard $2 \times 2$ Heckscher-Olin (H-O) model, in which he shows that Foreign Direct Investment (FDI) in the FZs and in other parts of the country were both welfare decreasing. This is because increasing capital in the FZs will attract labor from the Domestic Zone (DZ). By applying the Rybczynski theorem, output of labor-intensive goods in the DZ decreases, while output of capital-intensive goods increases, which leads to a worsening of the distortion created by the tariffs, thus lowering the country's welfare. Moreover, Hamilton and Svensson (1982) show that Hamada's conclusion regarding the relative ranking of FDI in the FZs and in the DZ was incorrect. Those authors based their analysis on a standard $\mathrm{H}$ O framework. According to their conclusions, if FDI is subject to tariffs in a small-open economy, this indeed will lead to a reduction of welfare no matter where it is located.

Wong (1986) tries to resolve the seemingly conflicting conclusions of Hamada and Hamilton and Svensson. According to Wong, the conflicting results are caused by the different assumptions regarding which products are produced in the FZs, which products used to repay local as well as foreign factors of production, and whether these payments were taxed or not.

Miyagiwa (1986) constructs a model with three factors (land, labor, and capital) and three goods (food, and two types of industrial goods). Initially, the country produces only food and one industrial good. The government establishes FZs with the intention of diversifying the manufacturing sector and offers a subsidy to foreign firms. Miyagiwa shows that under certain conditions, the host country can increase welfare by establishing FZs and attracting FDI that diversifies production. The intuition behind this result comes from the general "theory of second best": if a previously existing distortion (the tariff) cannot be removed completely, the introduction of a countervailing distortion (the subsidy) may improve national welfare.

Other extensions of earlier studies include other factors as unemployment by (Young and Miyagiwa, 1987) and capital mobility (Chaudhuri and Adhikari, 1993). All previous 
studies assume full employment, which does not capture the reality of developing countries. Young and Miyagiwa introduce unemployment of the Harris-Todaro type and argue that the formation of FZs may work as a second-best policy that increases national welfare. Chaudhuri and Adhikari introduce inter-sector capital mobility, and an upward slopping supply function for foreign capital to conclude that the welfare effects of Economic Processing Zones (EPZs) formation are ambiguous, even in the presence of the Harris-Todaro model of unemployment. Din (1994) develops a model that incorporates a sector of domestically produced intermediate inputs, focusing on backward linkages between firms in the FZs and the domestic economy. In a three-sector general equilibrium setting, he shows that if the rest of the domestic economy produced intermediate goods, and these goods are internationally traded, the formation of an FZs will leave national income unchanged. If the intermediate input is non-tradable, then the formation of a free zone will increase national welfare depending on the input being relatively labor or capital intensive compared to the final good produced in the economy.

We now discuss some of the available literature that deals with the theory of the FZs. Following is a description of the main external studies that investigate the impact of the FZs on the host country.

1. UNCTAD, (1973): Export Polices in Developing Countries, the use of free zones as a means of expanding and diversifying exports manufactures from the developing countries ${ }^{17}$.

This study shows that the establishment of free zones by developing countries aims to encourage manufacturing exports and foster economic growth. If developing countries diversify their exports and use more incentives to attract foreign direct investment, there will be a lot of improvement in these economies in the area of employment, income, rollover effects and linkages to the rest of the economy. Finally, the study shows that establishing free export zones should be viewed in the context of the development strategy of the country.

2. Koichi Hamada, (1974): An Economic Analysis of the Duty - Free Zone ${ }^{18}$.

17 United Nations Conference on Trade and Development (UNCTAD), (1973). Export Polices in Developing Countries, the use of free zones as a means of expanding and diversifying exports manufactures from the developing countries, Geneva Agenda, August.

18 Hamada, K., (1974). An Economic Analysis of the Duty-Free Zone, Journal of International Economics, Vol. 4, pp 225-241. 
This study used a standard 2x2 Heckscher-Olin (H-O) model, where the capital-intensive goods were protected by a non-prohibitive import tariff. Hamada shows that FDI in the FZs and in the other parts of the country were both welfare decreasing, because increased capital in the FZs attracts labor from other parts of the country (domestic economy). By the Rybczynski Theorem, output of the labor-intensive goods in the domestic economy decreases, while output of the capital-intensive good increases, worsening the distortion created by the tariff and lowering country welfare. Additionally, the study showed that foreign capital invested in the FZ is potentially less costly to the host country than the same amount of foreign capital invested in the domestic economy. In the end, Hamada concludes that the potential consumption of the country does not necessarily improve as a result of the introduction of more investment in the $\mathrm{FZ}$, because the concentration of foreign investment in a particular region may cause social and political problems elsewhere that outweigh the cost and benefit of establishing FZs.

3. Carlos Alfredo Rodriguez, (1976): A note on the Economics of the Duty Free ${ }^{19}$.

This study tries to examine Hamada's results concerning the impact of the duty free. The main conclusion of Rodriguez study was that Hamada's study about free zones did not analyze the full effects of the establishment of free zones with respect to production and trade, both in the domestic economy and in the free zone. He argued that if capital was perfectly mobile between the FZ and the rest of the economy the host country could attain the same level of welfare as can be achieved under a free trade regime.

\section{UNIDO, (1980): Export Processing Zone (EPZs) in Developing Countries ${ }^{20}$.}

The aim of this study is to review the development of EPZs by comparing and studying different stages of development of EPZs in Asia. It then examines the objectives of the host country in establishing these EPZs. While doing so, the study assesses the impact of the EPZs in terms of their economic and social consequences in the host country. The main findings of this study were: 1) EPZs have succeeded in attracting foreign direct investment, 2) in the long term, success of EPZs relies on the education and human resources policies in the host country, 3) qualifying the employees and transfer of

19 Rodriguez C., A., (1976). A note on the Economics of the Duty Free, Journal of International Economics, Vol. 6, No. 4, pp 385-388.

20 United Nations Industrial Development Organization (UNIDO), (1980). Export Processing Zones in Developing Countries, UNIDO Working Papers No. 10, Vienna, August. 
technology are primarily limited to the nature of the production process used by the investors and the lack of complex production processes, and 4) the net impact of EPZs on the balance of payments is therefore considerably less than the value of exports. Thus, export earnings are offset largely by importation of raw materials.

5. Hamilton and Svensson, (1982): On the Welfare Effects of a Duty - Free Zone ${ }^{21}$.

The aim of this study is to extend Hamada's work and to examine his results regarding the welfare effects on the host country from establishing FZs, and whether incentives relocate domestic production when the duty free zone is opened toward the domestic economy. Hamilton and Svensson show that Hamada's conclusions regarding the relative importance of FDI in the FZs and in the domestic economy was incorrect. The study of Hamilton and Svensson is based on a standard H-O framework. According to its conclusions, if FDI is subject to tariff in a small-open economy it is indeed welfare reducing no matter where it is located. However, FDI in an established FZs reduces welfare relatively more than the same amount of FDI in the DZ.

6. David K.Y.Chu and Y.T.Ng, (1982): The Special Economic Zones of China, an economic - geographic appraisal ${ }^{22}$.

This study describes the special economic zones in China from a geographical point of view during the time of the communist system. It then shows the weakness and strengths of the special zones in China in attracting foreign investors. In the end, the study shows that the Chinese zones should enhance their infrastructure and the government should give more incentives to the investors like profit guarantees.

\section{David K.Y.Chu, (1982): The Costs of Four Special Economic Zones to China ${ }^{23}$.}

This study analyses the capital costs of establishing SEZs in China. It shows that there are two kinds of cost combined together when the country established SEZs. The first one relates to the construction of infrastructure and the second to the urban development of SEZs. It then shows that most of the capital cost of establishing SEZs is largely the responsibility of the host country (Chinese Government in this case). In the end, the study

21 Hamilton, C., and Svensson, L., (1982). On the Welfare Economics of a Duty-Free Zone, Journal of International Economics, Vol. 20 , pp 45 - 64. 22 Chu, D., Y., and Ng, Y., T., (1982). The Special Economic Zones of China, Department of Geography, the Chinese University of Hong Kong, March. 23 Chu, D., Y. (1982). The Special Economic Zones of China, an economic - geographic appraisal, Department of Geography, the Chinese University of Hong Kong, March. 
shows that the gain from establishing SEZs should not be assessed by its financial rewards, as there are other non-monetary benefits of SEZs.

\section{Michael Oborne, (1986): China’s Special Economic Zones ${ }^{24}$.}

The study aims to assess the effects of establishing of the SEZs on china's national economy. The study provides a review of the policy context and reforms, traces foreign trade and foreign direct investment performances, and then evaluates the SEZs in China. Furthermore, it examines the future role of SEZs in the light of China's experience. The study shows that SEZs were established as part of the new "open door policies" that took place in the 1970s. The main findings of this study are that there was an increase in foreign direct investment in SEZs, and at the same time, there was an increase in the infrastructure cost.

9. Kaz F. Miyagiwa, (1986): A Reconsideration of the Welfare Economics of a Free Trade Zone ${ }^{25}$.

This study aims to review the importance of Free Trade Zones (FTZs) in the world. It shows that the establishment of FTZs is an integrated part of the development strategy of many developing countries. The study confirms that in the last decade FTZs became more important and started to play a prominent role in developing international trade. It then criticized Hamada's model, and another model based on a multi sector mode for Krueger (1977). The main finding of Miyagiwa shows that establishing FTZs in a tariffridden economy increases national welfare.

10. Peter Warr, (1989): Export Processing Zones: The Economics of Enclave Manufacturing ${ }^{26}$.

The study examines the effects of EPZs on the host country. It finds that establishing EPZs is important for attracting foreign investment (while at the same time they are not useful for the domestic economy). The study indicates that gains from technology transfer have not been realized because the EPZs are generally isolated from the domestic economy and the EPZ companies have contributed little to the tax revenues. Finally, the

24 Oborne M., (1986). China’s Special Economic Zones, OECD development center, Paris

25 Miygiwa K., F., (1986). A Reconsideration of the Welfare Economics of a Free Trade Zone, Journal of International Economics Vol. 21 , pp 337 - 350.

26 Warr, P., (1989). Export Processing Zones: The Economics of Enclave Manufacturing, Research Observer 4, No. 1, The World Bank January. 
study concludes that establishing these zones could be extremely costly to the host country.

11. Kai Yuen Tsui, (1993): Welfare Effects and Optimal Incentive Package of Export Processing Zones ${ }^{27}$.

The study assesses the impact of EPZ on the host country. The main finding of this study shows that the benefits to the host country depend on the bargaining power between the government and the investors.

12. Karen I. McKenney, (1993): An Assessment of China's Special Economic Zones ${ }^{28}$.

The main aim of this study is to assess the Chinese experience in achieving its goals from establishing SEZs. It shows that the SEZs have been more successful in developing the Chinese economy and attracting foreign direct investment than in other areas of the economy. Moreover, the study indicates that the cost of attracting FDI is very high, especially in the areas of capital investment and infrastructure, because the Chinese experience shows that the costs of capital investment and infrastructure exceeded the gains from foreign investments in SEZs. Finally, the study shows that in the early stages of Chinese reform, the SEZs play a small role in enhancing the economy.

13. Joachim Ahrens and Astrid Meyer - Baudeck, (1995): Special Economic Zones in Central and Eastern Europe: Shortcut or Round about Way towards Capitalism? ${ }^{29}$

This study tries to assess the experience of developing countries in establishing special economic zones (SEZs) in order to apply it to Central and Eastern European countries (CEE) as an instrument to accelerate the economic restructuring and reform in these countries. Then it shows that if the authorities do not prove a strong commitment to implement market economy policies, the SEZs in CEE countries will not benefit the economy. In the end, the study shows that the experience of some countries like Poland (1989), Hungary (1982), Bulgaria (1988), and USSR (1990), in establishing SEZs is constrained by political and social issues and should be solved by introducing an

27 Tsui, K., Y., (1993). Welfare effects and Optimal Incentive Package of Export Processing Zones, International Economic Journal, Vol. 7, No. 2.

28 McKenney, K., (1993). An Assessment of China’s Special Economic Zones, The Industrial College of the Armed Forces National Defense University, Washington, D.C.

29 Ahrens J., Baudeck A., (1995): Special Economic Zones in Central and Eastern Europe: Shortcut or Round about Way towards Capitalism? Intereconomics, vol.30, No.2, pp 87-95. 
adequate economic and political framework. The study refers to the Chinese model to be followed by CEE countries.

14. Manwer Osreer, (1996): A Theoretical Study on the Free Zones, Experience of South Korea, Hong Kong, Singapore and Egypt ${ }^{30}$.

The objective of this study is to examine the experience of some countries in establishing free zones (FZs) and their role on the host country. The main results of this study were: 1) there are various definitions for the FZs, 2) there are different types of FZs, 3) the success of establishing FZs depends on conducting feasibility studies by the countries, and 4) there is a social impact on the host country from establishing FZs. In the end, the study gives many recommendations such as: a) conducting a feasibility study before establishing the FZs, b) the country should draw on and benefit from the experience of other countries, and c) flexibility and decentralization of managing and operating the FZ is very important to ensure the benefits from it.

15. Zwena Ryal, (1997): Free Zones and Development, Study in Industrial Export Zones the Case of Tunisian, Morris Island, and Algeria ${ }^{31}$.

This study tries to review the experience of some African countries in establishing Industrial Export Zones (IEZ) in their economies. It then tries to determine the reasons behind the success and failure of these zones by clarifying their concept from a theoretical point of view. While doing so, the study found that establishing IEZs by developing countries should be combined with a national strategy and a commitment from the government. In the end, the study concludes that establishing IEZs is costly to developing countries.

16. Giovanni Fachini and Gerald Willmann, (1998): The Gain from Duty Free Zones ${ }^{32}$.

This study focuses on the welfare effects of duty free zones. It begins with a brief review of the literature about duty free zones. It then tries to extend the research by developing a theoretical model to measure the welfare impact of a duty free zone. The study finds that there is a positive relation between welfare and duty free zones.

30 Osreer, M., (1996). A Theoretical Study on the Free Zones, Experience of South Korea, Hong Kong, Singapore and Egypt, Master thesis, University of Algeria, Algeria. 31 Ryal, Z., (1997). Free Zones and Development, Study in Industrial Export Zones the Case of Tunisian, Morris Island and The Horizon of Established Free Zone in Algeria, Master thesis, University of Algeria, Algeria.

32 Facchini, G., and Willmann, G., (1998). The Gains from Duty Free Zones, Department of Economics, Stanford University, Stanford, CA 94305-6072, U.S.A., October. 
17. Dorsati Madani, (1998): A Review of the Role and Impact of Export Processing Zones ${ }^{33}$.

This study reviews the experience of two African countries in establishing EPZs. It concludes that EPZs are not the first best policy choice of the country. Thus, the best policy is to liberalize the economy first. Then, it shows that establishing EPZs in a country that has undertaken trade and macroeconomic reforms is undesirable for the following reasons: 1) the inflow of FDI will be low and only due to an inadequate regulatory framework, 2) the EPZ will lead to a distortion trade instruments, and 3) the EPZ is not the best instrument in order to develop the economy. Furthermore, the study shows that in order to keep existing EPZs in the country there is a need for the government to follow: a) sound and stable monetary and fiscal policies, and b) moderate income and corporate tax rates, thus no need to wave all taxes.

18. Jamil Taher, (1998): An Assessment of Free Economic Zone in Arab Countries: Performance and Main Features ${ }^{34}$.

This study assesses and examines the establishment of free economic zones in Arab countries in terms of promoting exports, employment creation, and enhancing foreign trade. The main conclusion of this study is that the free zones in Arab countries must compete on the basis of quality for the services offered and the goods produced in these zones.

19. Mauricio Jenkins, Gerardo Esquivel, and Felipe Larraín B. (1998): Export Processing Zones in Central America ${ }^{35}$.

This study analyzes the establishment of Export Processing Zones (EPZs) in Central America. It argues that developing countries can take advantage of the opportunities provided by EPZs, e.g. to attract technology, an upgrading of labor and managerial skills, and greater access to foreign markets. The study ends with a set of policy proposals, among them the promotion and diversification of export-oriented industries, the development of stronger backward linkages, and an improvement of the export-oriented legislation in Central America.

33 Madani, D., (1998). A Review of the Role and Impact of Export Processing Zones, World Bank publication.

34 Tahir, J., (1998). An Assessment of Free Economic Zones (FEZs) in Arab Countries: Performance and main features, international conference on "New Economic Developments and Their Impact on Arab Economies” Tunis, 3-5 June.

35Jenkins, M., Esquivel, G., and Larraín, F., (1998). Export Processing Zones in Central America, Harvard Institute for International Development, Development Discussion Paper No. 646, August. 
20. Wei Ge, (1999): The Dynamics of Export Processing Zone ${ }^{36}$.

This study uses a monopolistic pricing model and develops a dynamic framework to measure the role of export processing zones on the host country. It suggests that EPZs may serves as an effective policy tool in achieving greater economic openness and growth if implemented properly by the host country.

21. Claus Knoth, (2000): Special Economic Zones and Economic Transformation: The Case of the People's Republic of China ${ }^{37}$.

This study aims to review and analyze the Chinese experience in establishing SEZs during the transformation process, in order to measure their impact on the host country. The study uses a theoretical model as well as empirical analyses to examine the effects of SEZs on the economy. The study admits that using mathematical and theoretical models are not of too much help for a comprehensive analysis of the impact of the SEZs on the host country. In the end, the study gives some recommendations to policy makers that should be taken into account if a country decides to establish a SEZ. The main recommendations drown from this study were: a) the country should determine its aims from establishing SEZs, whether these aims are short or long terms, b) The location decisions of the zones, whether these zones will be established in backward areas or forward areas, c) The availability of high skilled labor in the country, and d) the planned of tax incentives offered to the investors.

22. Ukrainian Center for Independent Political Research (2000): Free Economic Zones in Ukraine, genesis, trends and prospects ${ }^{38}$.

This study focuses on the effectiveness of the special economic zones in Ukraine in the early 1990s. The study argues that there were some transitional economies, such as the one in China in the 1970s that play a big role for a fast and unrestrained development towards free market mechanisms. In the end, the study shows that the history of the development of special economic zones offers only very few convincing positive examples. Therefore, SEZ development trends in Ukraine remain uncertain, and their prospects remain unclear.

36 Wei, Ge, (1999). The Dynamics of Export-Processing Zones, United Nations Conference on Trade and Development (UNCTAD).

37 Knoth, C., (2000). Special Economic Zones and Economic Transformation: The case of the People's Republic of China, PhD thesis, University of Konstanz, Germany.

38 Ukrainian Center for Independent Political Research, (2000). Free economic zones in Ukraine: genesis, trends and prospects, Vol. 6, No. 189, October, 2. 
23. M. Tekere, (2000): Export Development and Export-led Growth Strategies: Export Processing Zones and the Strengthening of Sustainable Human Development ${ }^{39}$.

This study aims to review the role of establishing EPZs in Africa. It indicates that most zones in Africa have failed in achieving the objectives of establishing successful EPZs due to the following reasons: 1 ) the lack of government commitment to the program that lead to reversals of the objectives, 2) The high cost of infrastructure development of the EPZs, 3) government bureaucracy, 4) The poor selection of locations that led to a failure to attract investments, 5) the lack to continue with further trade reforms, and 6) the poor management and inadequate promotion of EPZs. The study concludes that EPZs are not a viable strategy for economic development in African countries. Today, EPZs are no longer viewed as a solution towards the development of exports for Africa in view of trade liberalization policies, regional trade integration, and new multilateral trade regimes.

24. Caleb Mireri, (2000): The Impact of Export Processing Zone Development on Employment Creation in Kenya ${ }^{40}$.

This study analyzes the experience of EPZ in Kenya by comparing the situations of workers inside and outside the EPZ. According to this study, there are negative results from establishing the EPZ such as: the insecurity of the workers due to the fluctuations in the number of enterprises operating in the EPZ. The employees inside the zones could be worse off than those who work outside the zones with respect to the wages paid inside and outside the EPZ. In addition, the situation is worse in the zones because most companies deliberately block trade union activity. In the end, the study shows other problems concerning the employees such as the lack of opportunities for training and promotion, racial discrimination, risks of industrial accidents and pollution.

25. Jean-Pierre Cling and Gaëlle Letilly, (2001): Export Processing Zones: A threatened Instrument for Global Economy Insertion ${ }^{41}$.

This study examines the potential impact of EPZs on the development of the host country. The facts show that the hopes put into such zones are frequently excessive and

39 Tekere, M., (2000). Export Development and Export-led Growth Strategies: Export Processing Zones and the Strengthening of Sustainable Human Development, African Meeting - Discussion Notes, May.

40 Mireri C., (2000). The Impact of Export Processing Zone Development on Employment Creation in Kenya, Singapore Journal of Tropical Geography, Vol. 21, No. 2, pp 149165

41 Cling,J., and Letilly, G., (2001). Export Processsing Zones: A Threatened instrument for global economy insertion?, Document de travail DIAL. 
unreal. Moreover, the study shows that the success of EPZs is ambivalent between countries and the experience of every single country differs from the other. In the end, the study indicates that the future of EPZs will depend on the quality of human capital and access to international markets.

26. Robert D. Sinclair, (2001): Export Processing Zones: An Ingredient for Successful Liberalization $^{42}$.

This study tries to examine the impact of foreign direct investment in EPZs on the economy before and after opening the economy to liberalization (Transformation Process). Using the neoclassical growth model, the study measures the impact of EPZs on the growth rates of per-capita income by including unemployment and intermediate goods in the model. The study found that EPZs contribute around 0.50 percent to the per capita growth of the economy. The study concludes that an expansion of establishing EPZs in the country will lead to an increase in national income.

27. Nguyen Ngoc Ninh, (2001): An Evaluation of Export Processing Zones in Vietnam's Industrialization Process ${ }^{43}$.

This study analyzes the roles of the Export Processing Zones (EPZs) in Vietnam during the development process of its economy by using a descriptive, analytical framework. It then compares EPZ development in Taiwan, Korea, Malaysia and China to draw lessons for the Vietnam economy. In the end, the study shows that there are direct and indirect benefits for the country from establishing EPZs in Vietnam.

28. Mustapha Sadni-Jallab and Enrique Blanco de Armas, (2002): A Review of the Role and Impact of Export Processing Zones in World Trade: The Case of Mexico ${ }^{44}$.

The main objective of this study is to review the role and impact of EPZs in terms of foreign exchange earning, employment, FDI, and technology transfer. The study used qualitative data for the Mexican economy to measure the impact of EPZs on the economy. The main finding was that there are various positive impacts on the economy from establishing EPZs with the exception of foreign exchange earning, which was limited.

42 Sinclair R., D., (2001). Export Processing Zones: An Ingredient for Successful Liberalization, The Maxwell School of Syracuse University, Department of Economics, May. 43 Ninh N., (2001). An Evaluation of Export Processing Zones in Vietnam's Industrialization Process, Master thesis, National Economics University, Vietnam. 44 Sadni-Jallab, M., and de Armas, E., B., (2002). A Review of the Role and Impact of Export Processing Zones in World Trade: The Case of Mexico, International Conference on "Exchange Rates, Economic Integration and the International Economy" The Department of Economics, Ryerson University, Toronto, Canada, May, 17-19. 
29. Albert G. Schweinberger, (2003): Special Economic Zones (SEZ) in Developing and / or Transition Economies: A Policy Proposal ${ }^{45}$.

This study tries to analyze the role of establishing SEZs in the host country with respect to taxes. The main finding of this study shows that establishment of SEZs accompanied by appropriate tax policies, will lead to an increase in government revenue. This revenue may be used to finance other investments in infrastructure or other public goods.

30. Meng Guangwen, (2003): The Theory and Practice of Free Economic Zones: A case of Tianjin, People's Republic of China ${ }^{46}$.

This study analyses both the historical development and the structure of Free Economic Zones (FEZs) in China as well as worldwide. While doing so, the study shows that there are around six generations of FEZs in the world. It then shows that in the 1990s, countries started to establish FEZs based on the Chinese experience e.g. in the former Soviet Union. In the end, the study advises Least Developing Countries (LDCs) to establish FEZs to promote regional economic development.

31. International Confederation of Free Trade Unions (ICFTU), (2003): Export Processing Zones - Symbols of Exploitation and a Development Dead-End ${ }^{47}$.

This study tries to evaluate the role of EPZ in the host countries under the WTO agreement and the Multi Fiber Agreement on textiles. It examines the impacts of these zones on the economy and workers as well as on wages. The study concludes from the experience of various countries that EPZs are generally costly to the host country and are beneficial only for a short period. In the end, the study shows that EPZs failed to introduce a model for economic development in developing countries.

32. Jayanthakumaran, Kankesu (2003): Benefit-Cost Appraisals of Export Processing Zones: A Survey of the Literature ${ }^{48}$.

This study tries to review the literature regarding the performance of EPZs using a cost benefit analysis. It then shows that the experiences of some countries, like Malaysia, South Korea, and Sri Lanka, indicate that there are benefits to these countries from

45 Schweinberger, A., G., (2003). Special Economic Zones in Developing and/or Transition Economies: a Policy Proposal, Review of International Economics, Vol. 11 No. 4, pp 619-629.

46 Guangwen, M., (2003). The Theory and Practice of Free Economic Zones: A Case Study of Tianjin, People’s Republic of China, PhD thesis, University of Heidelberg, Germany.

47 International Confederation of Free Trade Unions (ICFTU), (2003). Export Processing Zones, Symbols of Exploitation and a Development Dead-End, September.

48 Jayanthakumaran, K., (2003). Benefit-Cost Appraisals of Export Processing Zones: A Survey of the Literature, Development Policy Review, Vol. 21, No. 1, pp 51-65. 
establishing EPZs. At the same time, the study shows that there are also negative impacts in other countries such as in Philippines.

33. Chang Woon Nam and Doina Maria Radulescu, (2004): Types of Tax Concessions for Attracting Foreign Direct Investment in Free Economic Zones ${ }^{49}$.

This study tries to measure the net present value of Free Economic Zones (FEZs). It compares the tax incentive effects with inflation and without inflation. It then analyzed the effects of incentives offered to the foreign investors in the FEZs. In the end, the study concludes that imposing a lower corporate tax rate in the FEZ can be preferable. In addition, the study shows that using free depreciation as a tax concession when inflation is zero guarantees a higher net present value to the investor rather than when using an investment tax allowance and accelerated depreciation.

34. Chi-Yung NG, John Whalley, (2004): Geographical Extension of Free Trade Zones as Trade Liberalization: A Numerical Simulation Approach ${ }^{50}$.

This study tries to examine the impact of the size of the Free Trade Zones (FTZ) on the welfare of the country. The study compare between the FTZ and the local economy based on the differential tariff rates between these two areas. It is shows that the welfare costs of imposing geographical restrictive schemes are substantially larger than the cost of imposing national tariffs. The welfare impacts of trade liberalization through a geographical expansion of FTZs will likely be larger than the liberalization through conventional national tariff reductions.

49 Nam, C. W., and Radulescu, D., M., (2004). Types of tax concessions for attracting foreign direct investment in free economic zones, CESIFO Working Paper No. 1175, April. 50 NG, C., and Whalley, J., (2004). Geogarphical Extension of Free Trade Zones as Trade Liberalization: A Numerical Simulation Approach, CESifo Working Paper No. 1147, March. 


\section{CHAPTER 4}

\section{METHODOLOGY OF THE STUDY}

\subsection{Introduction}

After the signing of the peace treaty between Jordan and Israel in 1994, a bilateral cooperation between the two countries started to take place. This cooperation covered all issues that have been unsolved for around half a century. The outcomes of the peace treaty were a total of 15 bilateral agreements (A total of 15 agreements followed the establishment of peace between the two countries). During the Doha Summit in 1997, Jordan, Israel and the United States of America (USA) signed an agreement to promote economic cooperation and to support the peace process in the Middle East.

An important part of this trilateral agreement was the establishment of Qualifying Industrial Zones (QIZs) in Jordan. A QIZ can be defined as an industrial park, designated by the US government that can be setup in either the Gaza Strip, Israel or Jordan. Goods produced in these zones can be exported to the USA duty and quota free. For example, goods produced in these zones must contain a minimum of Israeli content between ( 7 to 8 percent), at least 11.7 percent of a product's content should be from Jordan. These input shares, if not reaching 35 percent, may be complemented by contributions from companies based in the West Bank / Gaza Strip, a QIZ, Israel or the USA. The remaining 65 percent of a product's content can be imported from anywhere in the world. Actually, the QIZ agreement represents an amendment to the 1985 Israeli - USA Free Trade Agreement (IFTA), where Israeli products were guaranteed duty-free entry to the US market.

The establishment of the first QIZ in Jordan was followed with great attention from all participants of the agreement for particular reasons. First, this political construct was supposed to increasingly enhance the relation between the Israeli and Jordanian societies by first integrating them on an economic level. Second, it was believed that the 
establishment of QIZs would attract Arab investors to invest in these zones. Third, potential adoption of the QIZ system by other Arab countries could also improve their relation with Israel.

To date, there have been few assessments of the impact of the QIZs on the Jordanian economy. This study aims at filling this gap by analyzing the potential impact these zones may have had over the past eight years on the national economy, and the region as a whole. In addition, and in contrast to other studies, this study assesses costs and benefits of establishing such zones in Jordan.

Less than ten years have passed since the establishment of the first QIZ in Jordan. Economically, data about the QIZs reveal an impressive performance. For instance, during the years 1999 to 2004 manufacturing exports increased by an average of 340 per cent per year. Politically, the success was less visible as the situation between Israel and Jordan is still unstable. No major changes have been made towards normalization between the two countries, primarily because the majority of the Jordanian Population is originally Palestinian (see Prados, 2006 and UNRWA, 2005). Relations between Israel and Jordan continue on highly official delegation levels and via business deals, in order to cover the content conditions as required in the QIZ agreement. Finally, due to the fact that most of the QIZ investors are from Asian countries, financial interaction or cooperation between Israel, Jordan and other Arab countries also remains weak.

For the descriptive analysis in this chapter qualitative data was used of companies working in the Qualifying Industrial Zones (QIZs) in Jordan. The field research was conducted from mid July towards the end of September 2005. A questionnaire and sets of interviews were used as tools to collect the data from these companies. The questionnaire was designed to cover different aspects regarding company profile, economic and fiscal impact on the country, and the future scheme for QIZ companies to work under QIZ status. The interviews helped to provide more in depth information from an internal stand point. The baseline data for QIZ location and number of companies were obtained from the Ministry of Industry and Trade (MIT). During the field research two phenomena could be observed. First, many companies were closed down, that is only 50 out of the 60 
companies listed on the MIT tables were found operating and having QIZ status. Secondly, many related and supporting companies were established and surrounding the main companies.

\subsection{Background}

Since establishing the first QIZ in 1998, Jordan has actively driven and sustained its domestic exports for more than eight years. Moreover, the QIZs had a positive impact on other sectors in the economy, such as services and trade. Today, QIZs play the main role in accelerating exports and employment creation in the country, thereby setting an example to be adopted by other countries. After the success of the first QIZ in Irbid ${ }^{51}$, expansion of QIZs took place throughout the country. Currently there are thirteen QIZs, four of which are publicly owned and organized, while the other nine are privately owned and organized. Yet, out of the thirteen, there were only seven zones in operation at the time of conducting the study. According to the MIT data, the total number of QIZs companies operating in these zones reached 60. More detailed information about the QIZs are given in Tables 4.1 and 4.2. Manufacturing export from QIZs jumped from US\$ 2, 4 Million in 1999 to reach around US\$1121.2 million in 2004 and make up around 34 percent of Jordan's domestic exports. Table 4.1 demonstrates the tremendous development of the QIZs between 1999 until July 2005 now regarding number of companies and value of exports.

Table 4.1: Export of QIZs Companies

\begin{tabular}{||l|c|c|c|c|c|c|c||}
\hline & $\mathbf{1 9 9 9}$ & $\mathbf{2 0 0 0}$ & $\mathbf{2 0 0 1}$ & $\mathbf{2 0 0 2}$ & $\mathbf{2 0 0 3}$ & $\mathbf{2 0 0 4}$ & $\begin{array}{c}\text { Jan - Jul } \\
\mathbf{2 0 0 5}\end{array}$ \\
\hline Number of companies & 2 & 12 & 38 & 43 & 49 & 55 & 60 \\
\hline $\begin{array}{l}\text { Export from QIZ's (US\$ } \\
\text { Million) }\end{array}$ & 2.4 & 25.1 & 150.3 & 381.7 & 574.0 & 1121.2 & 613.8 \\
\hline Percentage change & - & 945.8 & 498.8 & 153.9 & 50.3 & 48.1 & - \\
\hline As share of Domestic Export & 0.1 & 1.7 & 7.9 & 17.4 & 24.8 & 34.1 & 29.0 \\
\hline
\end{tabular}

Source: Industrial Development Directorate, Ministry of Industry and Trade (MIT), and MIT bulletin.

The outstanding result of table 4.1 led many observers to appraise the importance of QIZ to the economy. As regards employment creations, the QIZs succeeded in attracting local employees from rural areas located near to the zones, as well as foreign employees from

\footnotetext{
${ }^{51}$ Irbid is one of the main cities in Jordan located in the north of the capital Amman.
} 
Far East countries such as India, Pakistan, Bangladesh and Sri Lanka. Total number of employees in all QIZs companies reached around 30,013 thousand in 2004. The tremendous increase in exports and jobs by companies operating in the zones led the government to pay more attention to them, and expand them around the country. Officials from Jordan and the USA have praised QIZs for helping to spark economic growth in the country through export and reduce unemployment. Others observers note that QIZs, while promoting Israel, USA, and Jordan trade; have had modest impact on Jordan's economy ${ }^{52}$. According to MIT published data, table 4.2 shows the main development of QIZs over the years 1999 to 2004

Table 4.2: Employment and Value of Investment in the QIZs

\begin{tabular}{||l|c|c|c|c|c|c||}
\hline & $\mathbf{1 9 9 9}$ & $\mathbf{2 0 0 0}$ & $\mathbf{2 0 0 1}$ & $\mathbf{2 0 0 2}$ & $\mathbf{2 0 0 3}$ & $\mathbf{2 0 0 4}$ \\
\hline Employment & 4.000 & 6.584 & 19.000 & 23.503 & 28.639 & 30.013 \\
\hline Locals & 1.400 & 2.500 & 13.300 & 13.867 & 16.175 & 16.770 \\
\hline Foreign & 2.600 & 4.084 & 5.700 & 9.636 & 12.464 & 13.243 \\
\hline $\begin{array}{l}\text { Value of investment } \\
\text { (US\$ Mil) }\end{array}$ & 13.0 & 43.0 & 171.0 & 190.0 & 189.0 & 203.0 \\
\hline
\end{tabular}

Source: Industrial Development Directorate, Ministry of Industry and Trade.

Note: Value of investment and employment is accumulated every year.

\subsection{Previous Work}

There are only a few studies in the literature investigating the effects of QIZs on the Jordanian economy. These studies show the main advantages the establishment of these zones had, with respect to export and employment. The main studies which have been found were conducted by Kardoosh, 2004, Al Khouri, 2001; Manneh, 2003; Gaffney, 2005.

For instance, Al khouri, 2001 found that the country benefit a lot from establishing QIZs, particularly from employment creation. Using descriptive data from MIT, Al Khouri consider these zones a model for the industrial development and will solve unemployment problem in the country. Manneh, 2003 depend on different sources of data such as MIT and JIB, indicates the importance of these zones to the country regarding employment and foreign currency earning, while Kardoosh, 2004 shows with more

\footnotetext{
${ }^{52}$ Bolle, M. J., et al., (2006). Qualifying Industrial Zones in Jordan: A Model for Promoting Peace and Development in the Middle East? CRS Report for Congress
} 
attentions some of the negative sequences that the zones had, such as the uncertainty of continuing these zones in the future. Gaffney 2005 draws cloudy look about the future of QIZs in the country despite its positive effect on the country from different aspects such as, cultural changes, increasing of export and employment.

Most of these studies depend on different sources of data on QIZ, as a result mixed up and various conclusions could be drowning from these data. Overall result will not tell us about the whole effects of these zones on the country.

\subsection{Imitation of the QIZ Model}

Even though agreements were offered to Jordan, Gaza strip / West Bank and Egypt during the 1997 Doha summit, only Jordan and Egypt signed the QIZ agreement with Israel and the USA. Most recently, the USA became more generous in offering QIZ schemes to other countries in order to develop strong trade relations with them, and to support economic growth in these countries. However, after the success story of QIZs in Jordan, other countries started to negotiate to adopt such zones. In 2004 Egypt signed a QIZ agreement with Israel and the USA. Bahrain, in the same year, signed a free trade agreement with the USA as a root to sign a QIZ agreement in the future. In order for Bahrain to benefit from the agreement and coming into force it should ending the boycott of Israeli goods. In addition, Philippines, Turkey, Pakistan and Afghanistan are pushing the USA forward to adopting a QIZ model to expand their garment industry. Table 4.3 indicates the main countries, which signed a QIZ agreement with the USA and Israel as well, as those negotiating to establish QIZ on their territories.

Table 4.3: Main Countries, which Signed QIZ Agreements, and Negotiate to Set Up QIZs

\begin{tabular}{||l|l||}
\hline \multicolumn{1}{|c|}{ Country } & \multicolumn{1}{c|}{ QIZ Status } \\
\hline Egypt & Signed QIZ agreement between Israel and USA \\
\hline Bahrain & Signed FTA with USA \\
\hline Sub Saharan countries & Signed QIZ agreement with USA \\
\hline Philippines & In Negotiation to set up QIZ with USA \\
\hline Turkey & In Negotiation to set up QIZ with USA \\
\hline Pakistan & In Negotiation to set up QIZ with USA \\
\hline Afghanistan & In Negotiation to set up QIZ with USA \\
\hline \hline
\end{tabular}

Source: bilateral agreements can be found in the following website: http://www.bilaterals.org 


\subsection{Methodology of the Study}

This study can be considered as pioneering research in the field of Qualifying Industrial Zones (QIZs), both in Jordan, and in the context of developed and developing countries. The study aims at measuring the zones' economic impact, and to suggest policies and procedures for improving the QIZs scheme. The principal method used is a survey of all companies operating in Jordan's qualifying zones in the summer of 2005. A period of about two months was spent in Jordan carrying out this fieldwork, and the objectives were four-fold: (1) to collect all possible and available primary data on the companies working in the QIZs and therefore having the privilege to export to USA market under the QIZ agreement, (2) to gather all available related secondary information pertaining to the research work, (3) to ensure more credibility and clearness on the data of QIZs companies, and (4) to discover the future schemes of these kind of zones from the investors' point of view.

Generally, the chapter discusses the main issues involved in survey design and data collection. Some information will be provided concerning the method of data analysis to be carried out in the next chapter.

\subsubsection{Consistency of Data}

The data collected in this study have some inconsistencies. These can be summarized as follows. The first QIZ was established in 1997, however did not start operating before 1999, with only two companies. Therefore, a not sufficient amount of data could be collected to evaluate the longer-term impacts of the scheme. The information provided by the Ministry of Industry and Trade (MIT) is also not satisfactory, as it does not include historical details about employment, productivity per employee, values of investment or cost of production. In addition, data on QIZ companies are also published by many semi government and government institutions in the country, thereby contributing to the massive available amount of data sources.

The other difficulties we faced in this study were related to the companies operating in the QIZs. These include the company confidentiality of divulging information related to 
revenue, cost of production, number of employees or imports of raw material. Some companies even refused to fill out the questionnaire or to provide information under any circumstances. This problem made our mission to collect the data from the companies virtually impossible. Thus, it was not easy to collect the data that can help us to achieve the objectives of our study, which is to assess the overall impact of the zones on the economy.

Furthermore, some interviewee gave two different answers to similar questions and sometimes answers seemed exaggerated. But this problem was solved by cleaning up the data before working with them. Finally, as elsewhere, cooperation from the respondents to provide us with the needed information was sometimes weak and misleading. This is because the companies do not always trust the researchers to maintain the confidentiality of any data supplied and they fear that it might be passed on to the media or other governmental departments. They also do not believe that they will get any benefits from the results of the research. Such beliefs push some companies to refuse to respond, while others show reluctance to give their answers quickly, indicating that they do not want to fully cooperate.

\subsubsection{The Questionnaire}

"The questionnaire is a pre-formulated written set of questions to which respondents record their answers, usually within rather closely defined alternatives” (Sekaran, 1992). Consequently, a number of criteria were used in designing the questionnaire for this study. The questions must be objective, should cover the widest range of possible answers reflecting different circumstances and should not be ambiguous.

The questionnaire was constructed and designed to elicit information specific to this study. The questionnaire was set up in English and was not translated into Arabic as most investors were foreigners and familiar with the English language. The complete questionnaire is given in Appendix 1. Its main structure is as follows: 
I. Section A. The interviewee: including questions concerning name, job title of the respondents, company name, investor nationality, product type, establishment year and name of the zone.

II. Section B. The company: the main information on the company, such as legal status, the value of investment, the financial resources, the number of employees at the start up of the company, the production stage, exports and imports, cost of production factors, and the transit time and cost to export to USA market.

III. Section C. The employee: the main information about local employment, such as the new jobs created and retained, share of women, difficulties in obtaining local employees, whether local employees taking this job were unemployed before, working hours and overtime, development of number of employees (local and foreign) since establishment, productivity per employee, wage structure, and if there is any transfer of employment within QIZ companies.

IV. Section D. The fiscal and economic impact of the company: questions about the fiscal and economic impacts of the companies on the economy. Whether the 'project' (of being a QIZ) led to the opening-up of new markets, development of new products, and introduction of a leadingedge technology. Other questions organized to follow up the impact on the local economy such as, the cooperation between the companies in the zone and local companies, sources of tax incentives and estimation about them. The rest of this section concentrates on the main reasons to invest in the QIZs such as, the duty and quota free export to US market, political and economic stability, investment climate and labor force.

V. Section E. The future scheme of QIZs: including questions about advantage and disadvantage of QIZs, difficulties facing investors to obtain the required value added, the challenge from opening new QIZs in other countries, and what it is better for investors to produce under QIZ status or Free Trade Agreement (FTA) with USA. 
The questions themselves were organized, in order to cover a wide range of possible responses concerning most aspects related to companies working in these zones. Some of the questions were multiple choice, others were yes-or-no questions, while again others were open ended, so that the respondents were not restricted in their answers. Answering these kinds of questions should not only be much quicker, but it was also anticipated that they should evoke a higher response rate. It was considered that the questionnaire may be too long, but the lack of reliable information about companies working in the QIZs and the differences of the data made this inevitable.

\subsubsection{Source of Data}

Several government and semi government organizations have been found publishing data on QIZs. These data are inconsistent and differ from one organization to another. These organizations were the Ministry of Industry and Trade (MIT), the Ministry of Labor (MOL), the Jordan Investment Board (JIB), and the Jordan Industrial Estates Corporation (JIEC). The differences in the data provided by these organizations concern areas like the number of companies, the value of investment and the labor force.

This study only considers companies which export to the USA under QIZ status. More precisely, the basic information used for structuring this study was provided by the Industrial Development Directorate/QIZ division, at the Ministry of Industry and Trade. It was agreed to use MIT data because it is the official body responsible to qualify products in order to export to USA under the QIZs status. According to the MIT data, there are thirteen QIZs located throughout the country (see appendix 2) ${ }^{53}$ : four QIZs run and organized under the umbrella of public industrial estates, and nine QIZs privately owned, that is organized and run by the private sector. The total number of companies operating on these zones was 60 (see appendix 3$)^{54}$. Taking into account the small number of companies, it was decided that the study should cover the whole population listed on the MIT table. Table 4.4 shows the main active zones and number of companies working in every zone as obtained from the MIT data.

\footnotetext{
53 For the map of Qualifying Industrial Zones in Jordan, see appendix 2.

${ }^{54}$ For more details about the companies according to its location, see appendix 3.
} 
Table 4.4: Active QIZs According to Location, and No. of Companies

\begin{tabular}{||l|c|c|c||}
\hline \multicolumn{1}{|c|}{ Industrial zone } & Location & $\begin{array}{c}\text { No. of } \\
\text { Companies }\end{array}$ & Status \\
\hline Al Tajamouat Industrial City & Amman & 22 & Active \\
\hline Al Hassan Industrial Estate & Irbid & 16 & Active \\
\hline Al Dulayl Industrial Park & Zarqa & 14 & Active \\
\hline Al Hussein Bin Abdullah II & Al Karak & 3 & Active \\
\hline Cyber city Park & Irbid & 2 & Active \\
\hline Al Qastal Industrial Park & Al Qastal & 2 & Active \\
\hline Al Zay Ready Wear & Al Ruseifah & 1 & Active \\
\hline \multicolumn{1}{|c|}{ Total } & & $\mathbf{6 0}$ & \\
\hline \hline
\end{tabular}

Source: Industrial Development Directorate, Ministry of Industry and Trade

In addition to the above mentioned active QIZs, there are two zones in process and four zones under construction, meaning they are planned to be opened in the future through attraction of investors. Also, one company, specializing in garments, has been found working in one of these zones without having QIZ status from the MIT and therefore does not export to the USA. Table 4.5 shows the main non-active zones according to their location.

Table 4.5: Not Active and Under Construction QIZs

\begin{tabular}{|l|l|c|c||}
\hline Industrial zone & \multicolumn{1}{|c|}{ Location } & $\begin{array}{c}\text { No. of } \\
\text { Companies }\end{array}$ & Status \\
\hline Al Mashta Industrial Park & Al Mashta & 0 & Not active \\
\hline Hillwood Hashemite Uni. & Zarqa & 0 & Not active \\
\hline Al Hallabat Industrial Park & Ad-dulayl & 1 & In process \\
\hline $\begin{array}{l}\text { Resources for Development \& } \\
\text { Investment Co.(Al Mawared) }\end{array}$ & Al Muwaqar & 0 & In process \\
\hline Aqaba QIZ & Aqaba & 0 & Not active \\
\hline Jordan Valley Gateway Park & Sheikh Hussein & 0 & Not active \\
\hline \hline
\end{tabular}

Source: Industrial Development Directorate, Ministry of Industry and Trade.

\subsubsection{Description of the Data}

A total of 60 questionnaires were distributed personally as well as by email to canvass the wider view of investors about the potential impact of QIZs on the national economy and their future scheme. Face-to-face interviews were conducted with key persons of QIZ companies where considered necessary. A total of 38 complete responses were received. In contrast to the MIT data, 10 out of the total 60 companies were found closed and not working, whereas the remainder ignored and refused to fill out the questionnaire. The response ratio registered at around 63.3 percent, and by excluding the closed companies from the total number of questionnaires, this ratio increased to 76 percent. In spite of the 
small sample size, the companies that refused and ignored to fill the questionnaire will not have any significant effect on the overall results. This is because that these companies have the same characteristics of other companies who accept to fill the questionnaire.

The questionnaire was designed to cover the following issues: company profile, economic and fiscal impact of the company on the economy, and the future scheme of the company to work in a QIZ. Various questions and inquiries have been asked to cover aspects like the cost of production, export and import, expenditure and revenue, production stage, number of employees (locals and foreigners), tax exemptions, productivity per employee, and technology transfer ${ }^{55}$.

Thus, we found that there are differences between the data obtained from MIT (Table 4.4) and ours, because the actual number of working companies is 50 and not 60 as was indicated by the MIT data ${ }^{56}$. Of course, the differences in the data base will lead to different conclusions regarding employment and capital investment in later chapters, when we start to analyze the data from the field research. Nevertheless, wherever possible, MIT data will be used to complete the missing data which could not be obtained during the field study.

Table 4.6 summarizes these differences both by showing the number of those companies listed on the MIT table, as well as those which were found to be closed and agreed or refused to fill out the questionnaire, respectively.

Table 4.6: No. of Companies, Closed, and Which Refused and Agreed to fill the Questionnaire

\begin{tabular}{|l|c|c|c|c||}
\hline \multicolumn{1}{|c|}{ Industrial zone } & MIT data & \multicolumn{3}{|c|}{ Field Research Data } \\
\hline \hline & $\begin{array}{c}\text { No. of } \\
\text { Companies }\end{array}$ & $\begin{array}{c}\text { Companies } \\
\text { Closed } \\
\text { Companies }\end{array}$ & $\begin{array}{c}\text { Companies } \\
\text { Agreed Fill the } \\
\text { Questionnaire }\end{array}$ & $\begin{array}{c}\text { Qefused } \\
\text { to Fill the } \\
\text { Questionnaire }\end{array}$ \\
\hline Al Tajamouat Industrial City & 22 & 4 & 16 & 2 \\
\hline Al Hassan Industrial Estate & 16 & 3 & 9 & 4 \\
\hline Al Dulayl Industrial Park & 14 & 2 & 9 & 3 \\
\hline Al Hussein Bin Abdullah II (Karak) & 3 & 0 & 2 & 1 \\
\hline Cyber City Park & 2 & 0 & 2 & 0 \\
\hline Al Qastal Industrial Park & 2 & 1 & 0 & 1 \\
\hline Al Zay Ready Wear & 1 & 0 & 0 & 1 \\
\hline Total & $\mathbf{6 0}$ & $\mathbf{1 0}$ & $\mathbf{3 8}$ & $\mathbf{1 2}$ \\
\hline
\end{tabular}

Source: Author calculations based on the field research.

\footnotetext{
${ }^{55}$ Results of these questions will be analyzed later on.

${ }^{56}$ See Appendix 2 for details on working companies.
} 
According to the data gathered, 10 companies were closed. Some of them closed at the end of 2004, others in early 2005. Reasons behind keeping them listed in the MIT table are unknown.

Following is a brief summary of the main working QIZ's according to their location, number of companies, value of investment, and employment. The information given is not consistent with that in the MIT table and in other studies which mostly rely on MIT data (see appendix 4) ${ }^{57}$ :

\section{a Al Hassan Industrial Estate}

The first area in the world to be granted QIZ status to export to USA market duty and quota free in 1998. It is owned and organized by Jordan Industrial Estate Corporation (JIEC, Public ownership). Currently, there are 16 working companies.

\section{a Al Tajamouat Industrial City}

Established in 1999 as a QIZ, it is owned and organized by the private sector, it is home to 22 companies operating under QIZ status.

\section{a Al Dulayl Industrial Park}

This privately owned and organized park is located $45 \mathrm{~km}$ northeast of Amman. The total number of companies operating in this zone reached 14.

\section{a Al Hussein Bin Abdullah II Industrial City - Karak}

The second QIZ set up by JIEC in 2001, located $110 \mathrm{~km}$ south of Amman, this zone opened for investors in 2001 and its operate under public ownership. Recently it is home to 3 companies.

\section{a Cyber City Park}

Represents the 6th QIZs granted QIZ status. The aim of this zone is to enhance the Information Technology industry in the country. Currently, this zone is home to 2 companies. Until now, only garments are produced in this zone.

\section{a Al Qastal Industrial Park}

A privately owned industrial park, located $20 \mathrm{~km}$ south of Amman. Currently, it is home to 1 company.

\section{- Al Zay Ready Wear}

It is the only Jordanian company to be granted QIZ status and is located in Al- Ruseifah, $30 \mathrm{~km}$ near Amman. This company specialized in manufacturing high quality men suits.

\footnotetext{
${ }^{57}$ See Appendix 4 for more details on the companies, location, number of employees and investment capital.
} 


\subsection{Outcomes from the Field Research}

\subsubsection{Closure of Companies in QIZs}

During the time of conducting the field research, many companies were found to have been closed down. According to the information given by the QIZ companies, there are at least seven reasons which may account for the closure of companies working in the QIZs: First, small companies may have been adversely affected by the increase in international competition, following the abolishment of the multi-fiber-agreement on garment. This result is clearly reflected in table 4.7 below, showing that most companies closed at the end of 2004 and the beginning of 2005, the time where the agreement was abolished. A second reason is the financial difficulties small companies are often exposed to. Third, some companies were closed because of fire due to technical mistakes or arson. These mistakes cost the investors a lot and led to the destruction of factories. Until now no reasons could be found as to the causes of the fires in the QIZ companies. A fourth reason for the closure of companies is related to changes in companies' names and their reopening in order to have access to more facilities and to better benefit from banks, laws and regulations. Fifth, some companies found it easy to invest and benefit from the agreement for a short period of time and closed after satisfying their crave for richness, thereby abandoning local and foreign employees without paying them their salaries. A sixth reason for closure might be the effects of opening new QIZs in Egypt, where there is a better infrastructure and even lower production costs than in Jordan. To date, this reason is not surely verified as companies closing down and leaving the country do not indicate where they head. However, some working companies in the zones indicated their willingness to open new branches in Egypt in order to either transfer their company in the future or work on both sides, while even other companies already opened some branches in Egypt. The seventh reason behind the closure of the companies is the government procedures and the speed of changing government decisions as well as laws. These changes affect investor liability and increase production costs. In addition, there are delays in the government approval of investors' orders in time. Table 4.7 shows the main companies which were found closed when the field research was conducted. 
Table 4.7: Main Companies which Found Closed during the Research Field

\begin{tabular}{|l|l|l|l||}
\hline Company Name & \multicolumn{1}{|c|}{ Location } & \multicolumn{1}{|c|}{ Status } & Date of Closure \\
\hline United Textile Group & Al Qastal & Closed & 2005 \\
\hline Texfile Jordan & Al Tajamout & Closed & $1 / 2005$ \\
\hline Al Qadi & Al Tajamout & Closed & Not available \\
\hline Royal Fashion & Al Tajamout & Closed & $3 / 2005$ \\
\hline Al Fan & Al Tajamout & Closed & $12 / 2004$ \\
\hline Bee Line & Al Dulayl & Fire & $6 / 2005$ \\
\hline Al Shamal & Al Hassan & Change name & Not available \\
\hline AL Mateen & Al Hassan & Change name & Not available \\
\hline Gals & Al Hassan & Closed & $3 / 2005$ \\
\hline Millennium & Al Hassan & Closed & Not available \\
\hline
\end{tabular}

Source: Field research.

In addition to these more recent company closures, also MIT data show that there are many companies found closed since the establishment of the first QIZ in 1999. Their impact will be taken into consideration when analyzing the net effects on the economy, particularly for the companies which were operated for a short time and closed later on.

\subsubsection{Subcontractor Companies}

It should be mentioned here that the field research shows another important result. In fact, there were many companies, not listed on the MIT table, found operating in the zones surrounding the main QIZ companies. These companies act as subcontractors for the main companies in the zones. For instance, the subcontractor companies accept to take part in any of the production stages of the main companies whenever the latter are not able to deliver their orders in time.

According to 2005 MOL data, the number of subcontractor companies amounted to 51 companies in July, however 5 out of these 51 companies were not operating anymore. The subcontractor companies are distributed in all zones and surrounding the main companies. Their total number of employees reached around 7,420 in 2005. Table 4.8 indicates the number of subcontractor companies and their corresponding location by industrial zone. 
Table 4.8: No. of Subcontractors Companies According to Location

\begin{tabular}{||l|c|c|c||}
\hline \multicolumn{1}{||}{ Industrial Zone } & Location & $\begin{array}{c}\text { No. of } \\
\text { Subcontractor } \\
\text { Companies }\end{array}$ & $\begin{array}{c}\text { Closed } \\
\text { Companies }\end{array}$ \\
\hline Al Tajamouat Industrial City & Amman & 15 & 1 \\
\hline Al Hassan Industrial Estate & Irbid & 23 & 3 \\
\hline Al Dulayl Industrial Park & Zarqa & 2 & 1 \\
\hline $\begin{array}{l}\text { Al Hussein Bin Abdullah II } \\
\text { Industrial City }\end{array}$ & Al Karak & 2 & 0 \\
\hline Cyper city Park & Irbid & 3 & 0 \\
\hline Al Qastal Industrial Park & Al Qastal, & 0 & 0 \\
\hline Al Zay Ready Wear & Al Ruseifah & 1 & 0 \\
\hline \multicolumn{1}{|c|}{ Total } & \multicolumn{4}{|c}{} \\
\hline
\end{tabular}

Source: Ministry of Labor, QIZ consultant office.

\subsection{Conclusion}

The field research results regarding working companies and number of employees diverge from the data obtained from the MIT. Only 50 companies out of the listed 60 were found working and having QIZ status. Of course, this difference will affect the final conclusion when evaluating the real impact of these zones on the economy. More transparency and disclosure of data regarding QIZ companies is needed both on the part of official bodies, such as the MIT, as well as the companies themselves. Nevertheless, it is too early to make any judgment about the impact of these zones. Still, two main phenomena could be observed from the qualitative data. First, the closure of the companies in the zones is a continuous phenomenon which may affect the economy as a whole and the reputation of the investment climate in the country. Some causes behind these closures could be prevented by appropriate government measures, to ensure continuity of foreign investment in the country as well as attracting new investors. A second phenomenon is the finding of subcontractor companies surrounding main companies to assist them with work.

Generally, the government should more strongly promote QIZ investments from locals. The latter could also benefit from experiences of foreign investors or could cooperate with them. By this, local investors may gain confidence about the QIZ industry, which represents a new industry in the country. 
Despite the closure of companies in the QIZs, it was noted that exports were increasing dramatically during the years 1999 to 2005. Reasons behind this increase could be the following: First, subcontractor companies may have contributed positively in reducing any supply shortages main companies were facing. Secondly, the increase in orders may have led existing companies to hire more employees and to work in shifts. A third reason could be that, following the increased foreign demand, existing companies established new production sites and consequently expanded employment.

In the next chapter, a more detailed descriptive analysis of the survey data will be presented, whereas in Chapter 6 we undertake some econometrics analysis of the data, to evaluate the potential impact of those zones on the economy. 


\section{CHAPTER 5}

\section{THE SURVEY RESULTS}

\subsection{Introduction}

This chapter is concerned with the qualitative analysis and presentation of the data collected as part of the survey of 38 companies. This is the sample of companies drawn from the overall population of 60 companies that qualified for duty-free access to the USA as part of the Qualifying Industrial Zones (QIZs) from 2000-2005. (The collection of these data was described in Chapter 4). The purpose of this chapter is to identify and examine the following kinds of information: profile of companies operating in QIZs, details of local and foreign employment, characteristics and financing of the companies, economic and fiscal effects of the QIZs on the economy, and the outlook for QIZs.

The intention of this chapter is to directly reflect the viewpoint of the investors on the impact of the QIZ program. The qualitative analysis of the chapter is based on a crosstabulation of variables and responses that appear in the questionnaire, distributed according to the zone location.

\subsection{Company Profile}

This section describes the characteristics of the interviewee and the company, including the job title of the interviewee, investor's nationality, type of QIZ, age of the company, legal status of the company, and number of employees. This type of information helps identify the nature of investors and the status of companies working in the QIZs. The information is summarized in tables 5.1 to 5.13 .

\subsubsection{The Interviewee}

The target interviewees for this study were managers of the QIZ companies. Unfortunately, general managers were often unavailable. In such cases, other key persons in these companies were interviewed. Among respondents, 79 percent were administrative managers, 13 percent were general managers, and 8 percent were financial managers (see 
table 5.1). These key persons were chosen because they were considered capable of providing the necessary information to the interviewer without great difficulty.

Table 5.1: The Interviewee

\begin{tabular}{|c|c|c|c|c|c|c|c|c|c|c|c|c|}
\hline \multirow[b]{2}{*}{ The Interviewee } & \multicolumn{2}{|c|}{$\begin{array}{c}\text { Al } \\
\text { Tajamouat } \\
\text { Industrial } \\
\text { City } \\
\end{array}$} & \multicolumn{2}{|c|}{$\begin{array}{c}\text { Al Hassan } \\
\text { Industrial } \\
\text { Estate }\end{array}$} & \multicolumn{2}{|c|}{$\begin{array}{c}\text { Al Dulayl } \\
\text { Industrial } \\
\text { Park }\end{array}$} & \multicolumn{2}{|c|}{$\begin{array}{l}\text { Al Hussein } \\
\text { Bin } \\
\text { Abdullah } \\
\text { II (Karak) }\end{array}$} & \multicolumn{2}{|c|}{$\begin{array}{c}\text { Cyber City } \\
\text { Park }\end{array}$} & \multicolumn{2}{|c|}{ Total } \\
\hline & No. & $(\%)$ & No. & $(\%)$ & No. & $(\%)$ & No. & $(\%)$ & No. & $(\%)$ & No. & $(\%)$ \\
\hline Manager & 2 & 12.5 & 1 & 11.1 & 1 & 11.1 & $\overline{1}$ & 50 & 0 & 0 & 5 & 13.2 \\
\hline Administrative Manager & 13 & 81.3 & 6 & 66.7 & 8 & 88.9 & 1 & 50 & 2 & 100 & 30 & 78.9 \\
\hline Financial Manager & 1 & 6.3 & 2 & 22.2 & 0 & 0 & 0 & 0 & 0 & 0 & 3 & 7.9 \\
\hline Total & 16 & 100 & 9 & 100 & 9 & 100 & 2 & 100 & 2 & 100 & 38 & 100 \\
\hline
\end{tabular}

Source: Field Research

\subsubsection{Investors’ Nationality}

Table 5.2 shows that the vast majority of investors in the QIZ companies are from Far East countries such as India, Sri Lanka, Pakistan, and China. Investors from the USA, Canada, and Europe accounted for about 8 percent, as did Jordanian investors. Meanwhile, Israeli investors represented less than 3 percent of all investors, thus seeming least interested in investing in the QIZs. This result is contrary to the expectation that the zones would attract mainly Jordanian and Israeli investors. As such, this undermines the goal of strengthening ties between the two countries through business interaction in the QIZs (see figure 5.1).

Table 5.2: Investors' Nationality

\begin{tabular}{|c|c|c|c|c|c|c|c|c|c|c|c|c|}
\hline \multirow[b]{2}{*}{ Investors' Nationality } & \multicolumn{2}{|c|}{$\begin{array}{c}\text { Al } \\
\text { Tajamouat } \\
\text { Industrial } \\
\text { City }\end{array}$} & \multicolumn{2}{|c|}{$\begin{array}{c}\text { Al Hassan } \\
\text { Industrial } \\
\text { Estate }\end{array}$} & \multicolumn{2}{|c|}{$\begin{array}{c}\text { Al Dulayl } \\
\text { Industrial } \\
\text { Park }\end{array}$} & \multicolumn{2}{|c|}{$\begin{array}{c}\text { Al } \\
\text { Hussein } \\
\text { Bin } \\
\text { Abdullah } \\
\text { II (Karak) }\end{array}$} & \multicolumn{2}{|c|}{$\begin{array}{l}\text { Cyber City } \\
\text { Park }\end{array}$} & \multicolumn{2}{|c|}{ Total } \\
\hline & No. & $(\%)$ & No. & $(\%)$ & No. & $(\%)$ & No. & $(\%)$ & No. & $(\%)$ & No. & $(\%)$ \\
\hline $\begin{array}{l}\text { Far East ( India, Sri Lanka, } \\
\text { Pakistan, Taiwan... etc) }\end{array}$ & 14 & 87.5 & 6 & 60 & 7 & 77.8 & 1 & 100 & 2 & 100 & 30 & 79.0 \\
\hline USA, Canadian and European & 0 & 0 & 3 & 30 & 0 & 0 & 0 & 0 & 0 & 0 & 3 & 7.9 \\
\hline Turkish & 0 & 0 & 0 & 0 & 1 & 11.1 & 0 & 0 & 0 & 0 & 1 & 2.6 \\
\hline Jordanian & 2 & 12.5 & 0 & 0 & 1 & 11.1 & 0 & 0 & 0 & 0 & 3 & 7.9 \\
\hline Israeli & 0 & 0 & 1 & 10 & 0 & 0 & 0 & 0 & 0 & 0 & 1 & 2.6 \\
\hline Total & 16 & 100 & 10 & 100 & 9 & 100 & 1 & 100 & 2 & 100 & 38 & 100 \\
\hline
\end{tabular}

Source: Field Research

\subsubsection{Value of Investment}

Table 5.3 reveals the value of investment inflow to Jordan by the investors in QIZs. While QIZs attracted around US\$ 122 million in investments from 2000 to 2004, the value 
fluctuations significantly during the studied period. In the early years, investments topped US\$46 million per year. In the years from 2002 to 2004, investments in QIZs witnessed a dramatic decrease, totaling just US\$33 million combined. This drop resulted from the volatile political situation in the region (i.e. the war in Iraq, and the ongoing PalestinianIsraeli conflict) and the global economic slowdown that began in 2001 (for more details see figure 5.2).

Table 5.3: Value of Investment

\begin{tabular}{|c|c|c|c|c|c|c|c|c|c|c|c|c|c|}
\hline \multirow[b]{2}{*}{$\begin{array}{l}\text { Value of } \\
\text { Investment }\end{array}$} & \multicolumn{2}{|c|}{$\begin{array}{c}\text { Al } \\
\text { Tajamouat } \\
\text { Industrial } \\
\text { City }\end{array}$} & \multicolumn{2}{|c|}{$\begin{array}{l}\text { Al Hassan } \\
\text { Industrial } \\
\text { Estate }\end{array}$} & \multicolumn{2}{|c|}{$\begin{array}{c}\text { Al Dulayl } \\
\text { Industrial } \\
\text { Park }\end{array}$} & \multicolumn{2}{|c|}{$\begin{array}{c}\text { Al Hussein } \\
\text { Bin Abdullah } \\
\text { II (Karak) }\end{array}$} & \multicolumn{2}{|c|}{$\begin{array}{c}\text { Cyber } \\
\text { City Park }\end{array}$} & \multicolumn{3}{|c|}{ Total } \\
\hline & No. & Value & No. & Value & No. & Value & No. & Value & No. & Value & Value & No. & (\%) \\
\hline 2000 & 3 & 8.7 & 5 & 9.3 & 1 & 3.5 & 2 & 24.7 & 0 & 0 & 46 & 11 & 37.9 \\
\hline 2001 & 4 & 8.6 & 1 & 6.5 & 4 & 22.5 & 0 & 0 & 2 & 5.1 & 43 & 11 & 35.0 \\
\hline 2002 & 5 & 9.2 & 0 & 0 & 0 & 0 & 0 & 0 & 0 & 0 & 9 & 5 & 7.5 \\
\hline 2003 & 1 & 4.2 & 3 & 9.8 & 3 & 4.1 & 0 & 0 & 0 & 0 & 18 & 7 & 14.8 \\
\hline 2004 & 3 & 3.6 & 0 & 0 & 1 & 2.1 & 0 & 0 & 0 & 0 & 6 & 4 & 4.7 \\
\hline Total & 16 & 17.3 & 9 & 15.8 & 9 & 32.2 & 2 & 24.7 & 2 & 5.1 & 122 & 38 & 100.0 \\
\hline
\end{tabular}

Source: Field Research

\subsubsection{Types of QIZs}

As was mentioned in chapter four, there are two types of QIZs - public and private. Table 5.4 shows in spite of the fact that companies operating in the public QIZs receive more incentives and tax exemptions, around two thirds of investors are operating in private QIZs. The main benefit of operating in private QIZs is that companies have no time limit to export during the day or holidays, in contrast to the public QIZs where such limitations exist. Also, private QIZs tend to be closer to the city center, providing better access to workers and infrastructure. The advantage of public QIZs appears to be in the area of tax exemption, infrastructure, and cost of production.

Table 5.4: Types of QIZs

\begin{tabular}{|c|c|c|c|c|c|c|c|c|c|c|c|c|}
\hline \multirow[b]{2}{*}{ Types of QIZs } & \multicolumn{2}{|c|}{$\begin{array}{c}\text { Al } \\
\text { Tajamouat } \\
\text { Industrial } \\
\text { City }\end{array}$} & \multicolumn{2}{|c|}{$\begin{array}{c}\text { Al Hassan } \\
\text { Industrial } \\
\text { Estate }\end{array}$} & \multicolumn{2}{|c|}{$\begin{array}{c}\text { Al Dulayl } \\
\text { Industrial } \\
\text { Park }\end{array}$} & \multicolumn{2}{|c|}{$\begin{array}{c}\text { Al Hussein } \\
\text { Bin } \\
\text { Abdullah } \\
\text { II (Karak) } \\
\end{array}$} & \multicolumn{2}{|c|}{$\begin{array}{c}\text { Cyber City } \\
\text { Park }\end{array}$} & \multicolumn{2}{|c|}{ Total } \\
\hline & No. & $(\%)$ & No. & $(\%)$ & No. & $(\%)$ & No. & $(\%)$ & No. & $(\%)$ & No. & $(\%)$ \\
\hline Public & 0 & 0 & 9 & 100 & 0 & 0 & 2 & 100 & 2 & 100 & 13 & 34.2 \\
\hline Private & 16 & 100 & 0 & 0 & 9 & 100 & 0 & 0 & 0 & 0 & 25 & 65.8 \\
\hline Total & 16 & 100 & 9 & 100 & 9 & 100 & 2 & 100 & 2 & 100 & 38 & 100 \\
\hline
\end{tabular}




\subsubsection{Age of the Companies}

The age of the companies operating in the QIZs is shown in Table 5.5. This table shows the start-up dates of the companies for the years 2000-2004. Approximately, 29 percent of the sampled companies were established in the year 2000, another 29 percent of them were started in the year 2001, and the remaining 42 percent were established between the years 2002 to 2004. Therefore, the maximum age for the companies is six years while the minimum age is two years. The number of new companies was clearly decreasing over time.

\section{Table 5.5: Age of the Companies}

\begin{tabular}{|l|c|c|c|c|c|c|c|c|c|c|c|c|}
\hline & \multicolumn{2}{|c|}{$\begin{array}{c}\text { Al } \\
\text { Tajamouat } \\
\text { Industrial } \\
\text { City }\end{array}$} & $\begin{array}{c}\text { Al Hassan } \\
\text { Industrial } \\
\text { Estate }\end{array}$ & $\begin{array}{c}\text { Al Dulayl } \\
\text { Industrial } \\
\text { Park }\end{array}$ & $\begin{array}{c}\text { Al Hussein } \\
\text { Bin } \\
\text { Abdullah } \\
\text { II (Karak) }\end{array}$ & \multicolumn{2}{c|}{$\begin{array}{c}\text { Cyber City } \\
\text { Park }\end{array}$} & \multicolumn{2}{|c|}{ Total } \\
\hline Establishment Year & No. & $(\%)$ & No. & $(\%)$ & No. & $(\%)$ & No. & $(\%)$ & No. & $(\%)$ & No. & $(\%)$ \\
\hline 2000 & 3 & 18.8 & 5 & 55.6 & 1 & 11.1 & 2 & 100 & 0 & 0.0 & 11 & 28.9 \\
\hline 2001 & 4 & 25.0 & 1 & 11.1 & 4 & 44.4 & 0 & 0.0 & 2 & 100 & 11 & 28.9 \\
\hline 2002 & 5 & 31.3 & 0 & 0.0 & 0 & 0.0 & 0 & 0.0 & 0 & 0.0 & 5 & 13.2 \\
\hline 2003 & 1 & 6.3 & 3 & 33.3 & 3 & 33.3 & 0 & 0.0 & 0 & 0.0 & 7 & 18.4 \\
\hline 2004 & 3 & 18.8 & 0 & 0.0 & 1 & 11.1 & 0 & 0.0 & 0 & 0.0 & 4 & 10.5 \\
\hline Total & $\mathbf{1 6}$ & $\mathbf{1 0 0}$ & $\mathbf{9}$ & $\mathbf{1 0 0}$ & $\mathbf{9}$ & $\mathbf{1 0 0}$ & $\mathbf{2}$ & $\mathbf{1 0 0}$ & $\mathbf{2}$ & $\mathbf{1 0 0}$ & $\mathbf{3 8}$ & $\mathbf{1 0 0}$ \\
\hline & & & & & & & & & & & & \\
\hline
\end{tabular}

Source: Field Research

\subsubsection{Status of Companies}

The legal status of the sample companies is presented in Table 5.6. Overall, about 70 percent of the companies are branches of mother companies. Another 21 percent of the sample companies are in private ownership, while the remaining companies are partnerships; the latter are registered as private shareholding companies (see figure 5.3).

The preponderance of branches reduces the impact on the local economy in the following ways. First, the existence of these companies within the QIZs is generally temporary and concentrated in the light manufacturing process of textile and apparel. Second, the parent company is responsible for most of the functions such as marketing and importation of raw materials. Thirdly, this kind of branch operation is part of a so-called 'footloose industry'. According to this model, companies maintain mobility, enabling them to move from one part on the world to another in search of the lowest cost of production. 
Table 5.6: Status of the Companies

\begin{tabular}{|c|c|c|c|c|c|c|c|c|c|c|c|c|}
\hline \multirow[b]{2}{*}{ Status of the Company } & \multicolumn{2}{|c|}{$\begin{array}{c}\text { Al } \\
\text { Tajamouat } \\
\text { Industrial } \\
\text { City }\end{array}$} & \multicolumn{2}{|c|}{$\begin{array}{c}\text { Al Hassan } \\
\text { Industrial } \\
\text { Estate }\end{array}$} & \multicolumn{2}{|c|}{$\begin{array}{c}\text { Al Dulayl } \\
\text { Industrial } \\
\text { Park }\end{array}$} & \multicolumn{2}{|c|}{$\begin{array}{c}\text { Al Hussein } \\
\text { Bin } \\
\text { Abdullah } \\
\text { II (Karak) }\end{array}$} & \multicolumn{2}{|c|}{$\begin{array}{c}\text { Cyber City } \\
\text { Park }\end{array}$} & \multicolumn{2}{|c|}{ Total } \\
\hline & No. & $(\%)$ & No. & $(\%)$ & No. & $(\%)$ & No. & $(\%)$ & No. & $(\%)$ & No. & $(\%)$ \\
\hline Branch of Mother Company & 11 & 68.7 & 6 & 66.7 & 6 & 66.7 & 2 & 100 & 2 & 100 & 27 & 71.0 \\
\hline Private Ownership & 3 & 18.8 & 2 & 22.2 & 3 & 33.3 & 0 & 0 & 0 & 0 & 8 & 21.1 \\
\hline Partners & 2 & 12.5 & 1 & 11.1 & 0 & 0 & 0 & 0 & 0 & 0 & 3 & 7.9 \\
\hline Total & 16 & 100 & 9 & 100 & 9 & 100 & 2 & 100 & 2 & 100 & 38 & 100 \\
\hline
\end{tabular}

Source: Field Research

\subsubsection{Location of QIZs}

Table 5.7 shows that about 42 percent of the sample companies are located in the capital Amman. Another 29 percent is in Irbid, 24 percent in Zarqa, and only 5 percent in Karak (see figure 5.4). The distribution of companies reflects the availability of nearby labor supply, transport, and government departments. Although, the government policy aims to attract investors in the rural area where the unemployment rate is high, QIZs in rural areas do not attract investors as much as in main cities such as Amman, Zarqa, and Irbid governorates. See appendix 2 for a map of the country.

Table 5.7: location of QIZs

\begin{tabular}{|c|c|c|c|c|c|c|c|c|c|c|c|c|}
\hline \multirow[b]{2}{*}{ Location (City) } & \multicolumn{2}{|c|}{$\begin{array}{c}\text { Al } \\
\text { Tajamouat } \\
\text { Industrial } \\
\text { City }\end{array}$} & \multicolumn{2}{|c|}{$\begin{array}{c}\text { Al Hassan } \\
\text { Industrial } \\
\text { Estate }\end{array}$} & \multicolumn{2}{|c|}{$\begin{array}{c}\text { Al Dulayl } \\
\text { Industrial } \\
\text { Park }\end{array}$} & \multicolumn{2}{|c|}{$\begin{array}{c}\text { Al } \\
\text { Hussein } \\
\text { Bin } \\
\text { Abdullah } \\
\text { II (Karak) }\end{array}$} & \multicolumn{2}{|c|}{$\begin{array}{c}\text { Cyber City } \\
\text { Park }\end{array}$} & \multicolumn{2}{|c|}{ Total } \\
\hline & No. & $(\%)$ & No. & $(\%)$ & No. & $(\%)$ & No. & $(\%)$ & No. & $(\%)$ & No. & $(\%)$ \\
\hline Amman & 16 & 100 & 0 & 0.0 & 0 & 0.0 & 0.0 & 0.0 & 0 & 0.0 & 16 & 42.1 \\
\hline Zarqa & 0 & 0.0 & 0 & 0.0 & 9 & 100 & 0 & 0.0 & 0 & 0.0 & 9 & 23.7 \\
\hline Irbid & 0 & 0.0 & 9 & 100 & 0 & 0.0 & 0 & 0.0 & 2 & 100 & 11 & 28.9 \\
\hline Karak & 0 & 0.0 & 0 & 0.0 & 0 & 0.0 & 2 & 100 & 0 & 0.0 & 2 & 5.3 \\
\hline Total & 16 & 100 & 9 & 100 & 9 & 100 & 2 & 100 & 2 & 100 & 38 & 100 \\
\hline Location (Region) & \multicolumn{2}{|c|}{ Middle } & \multicolumn{2}{|c|}{ North } & \multicolumn{2}{|c|}{ North east } & \multicolumn{2}{|c|}{ South } & \multicolumn{2}{|c|}{ North } & \multicolumn{2}{|c|}{-} \\
\hline & \multicolumn{2}{|c|}{$\%$} & \multicolumn{2}{|c|}{$\%$} & \multicolumn{2}{|c|}{$\%$} & \multicolumn{2}{|c|}{$\%$} & \multicolumn{2}{|c|}{$\%$} & \multicolumn{2}{|c|}{ Average } \\
\hline Unemployment Rate in Area & \multicolumn{2}{|c|}{9.1} & \multicolumn{2}{|c|}{16.2} & \multicolumn{2}{|c|}{10.1} & \multicolumn{2}{|c|}{21.5} & \multicolumn{2}{|c|}{16.2} & \multicolumn{2}{|c|}{14.6} \\
\hline
\end{tabular}

Sources: Field Research and Department of Statistics

\subsubsection{Size of the Company}

Questions were also asked to assess the size of the company, including its number of employees. Table 5.8 shows that nearly 90 percent of the sample companies employed more than 100 workers. In general, it is very rare to find a small or medium-sized company 
in the textile and garment industry working in the QIZs, because the industry is characterized by mass production and labor intensiveness.

Table 5.8: Size of the Company

\begin{tabular}{|c|c|c|c|c|c|c|c|c|c|c|c|c|}
\hline \multirow[b]{2}{*}{ Number of Employees } & \multicolumn{2}{|c|}{$\begin{array}{c}\text { Al } \\
\text { Tajamouat } \\
\text { Industrial } \\
\text { City }\end{array}$} & \multicolumn{2}{|c|}{$\begin{array}{c}\text { Al Hassan } \\
\text { Industrial } \\
\text { Estate }\end{array}$} & \multicolumn{2}{|c|}{$\begin{array}{c}\text { Al Dulayl } \\
\text { Industrial } \\
\text { Park }\end{array}$} & \multicolumn{2}{|c|}{$\begin{array}{c}\text { Al } \\
\text { Hussein } \\
\text { Bin } \\
\text { Abdullah } \\
\text { II (Karak) }\end{array}$} & \multicolumn{2}{|c|}{$\begin{array}{c}\text { Cyber City } \\
\text { Park }\end{array}$} & \multicolumn{2}{|c|}{ Total } \\
\hline & No. & $(\%)$ & No. & $(\%)$ & No. & $(\%)$ & No. & $(\%)$ & No. & $(\%)$ & No. & $(\%)$ \\
\hline \multicolumn{13}{|l|}{ Local } \\
\hline $0-24$ & 3 & 18.8 & 0 & 0.0 & 1 & 11.1 & 0 & 0.0 & 0 & 0.0 & 4 & 10.5 \\
\hline $25-49$ & 0 & 0.0 & 0 & 0.0 & 1 & 11.1 & 0 & 0.0 & 1 & 50 & 2 & 5.3 \\
\hline $50-100$ & 4 & 25.0 & 0 & 0.0 & 2 & 22.2 & 0 & 0.0 & 1 & 50 & 7 & 18.4 \\
\hline More than 100 & 9 & 56.3 & 9 & 100 & 5 & 55.6 & 2 & 100 & 0 & 0.0 & 25 & 65.8 \\
\hline Total & 16 & 100 & 9 & 100 & 9 & 100 & 2 & 100 & 2 & 100 & 38 & 100 \\
\hline \multicolumn{13}{|l|}{ Foreign } \\
\hline $0-24$ & 2 & 12.5 & 1 & 11.1 & $\mathbf{0}$ & 0.0 & $\mathbf{0}$ & 0.0 & $\mathbf{0}$ & 0.0 & 3 & 7.9 \\
\hline $25-49$ & $\mathbf{1}$ & 6.3 & $\mathbf{0}$ & 0.0 & $\mathbf{0}$ & 0.0 & $\mathbf{0}$ & 0.0 & $\mathbf{0}$ & 0.0 & 1 & 2.6 \\
\hline $50-100$ & 2 & 12.5 & 3 & 33.3 & 1 & 11.1 & 1 & 50 & 1 & 50 & 8 & 21.1 \\
\hline More than 100 & 11 & 68.8 & 5 & 55.6 & 8 & 88.9 & 1 & 50 & 1 & 50 & 26 & 68.4 \\
\hline Total & 16 & 100 & 9 & 100 & 9 & 100 & 2 & 100 & 2 & 100 & 38 & 100 \\
\hline \multicolumn{13}{|l|}{ Total Local and Foreign } \\
\hline $0-24$ & $\mathbf{0}$ & 0.0 & $\mathbf{0}$ & 0.0 & $\mathbf{0}$ & 0.0 & $\mathbf{0}$ & 0.0 & $\mathbf{0}$ & 0.0 & 0 & 0.0 \\
\hline $25-49$ & $\mathbf{0}$ & 0.0 & $\mathbf{0}$ & 0.0 & $\mathbf{0}$ & 0.0 & $\mathbf{0}$ & 0.0 & $\mathbf{0}$ & 0.0 & 0 & 0.0 \\
\hline $50-100$ & 4 & 25.0 & $\mathbf{0}$ & 0.0 & $\mathbf{0}$ & 0.0 & $\mathbf{0}$ & 0.0 & $\mathbf{0}$ & 0.0 & 4 & 10.5 \\
\hline More than 100 & 12 & 75.0 & 9 & 100 & 9 & 100 & 2 & 100 & 2 & 100 & 34 & 89.5 \\
\hline Total & 16 & 100 & 9 & 100 & 9 & 100 & 2 & 100 & 2 & 100 & 38 & 100 \\
\hline
\end{tabular}

Source: Field Research

\subsubsection{The Constraints Facing QIZs Companies}

Companies were also asked about the major constraints facing them. The results are given in Table 5.9. The main problems are placed in order from the most important to the least important according to the interviewee's point of view. Employment is the most important problem for companies in the sample, particularly finding and retaining workers. At the same time, around one third of the respondents consider the fulfillment of input share from Israel a problem. An explanation of the most important constraints facing the companies in the QIZs is given below.

i.Employment: The biggest problem perceived by respondents was finding local employees. Most of the respondents indicated that it was easy for them to obtain local employees in the early years of establishment, but at the time of the survey the demand for local workers by the companies in the QIZs exceeded the supply. This is unexpected given Jordan's persistently high unemployment. Companies are prohibited from filling the shortage with foreign employees because Jordanian labor law forces companies to hire a certain number of local employees, along with 
foreign employees. Companies in the QIZs found local employees were cheaper, but also less stable. Over 80 percent of the companies indicated that they suffered from serious fluctuation among local employees every month. The average turnover of local employees registered at around 20 employees per month. This severe problem led many companies to substitute local employees for foreigners, as the latter are considered more stable. The main reasons behind the instability of local employees in the QIZs might be summarized as follows: a) the textile industry in Jordan is considered a new industry, therefore qualified local employees were not available, b) the average income for local employees is rather low and does not exceed the minimum wage set by the government, unless the employees work overtime. Today, companies in the QIZs are still suffering from the instability of the group of local employees, in particular the shortage of skilled local employees. Some respondents indicated that local employees would be more beneficial to the companies, whereas others stressed that they prefer to hire foreign employees. Due to the instability of local employees, some companies hired local employees only to meet the labor law requirements, and to work in simpler lines of production.

Table 5.9: Constraints in Employment

\begin{tabular}{|c|c|c|c|c|c|c|c|c|c|c|c|c|}
\hline \multirow[b]{2}{*}{ Constraints in Employment } & \multicolumn{2}{|c|}{$\begin{array}{c}\text { Al } \\
\text { Tajamouat } \\
\text { Industrial } \\
\text { City }\end{array}$} & \multicolumn{2}{|c|}{$\begin{array}{l}\text { Al Hassan } \\
\text { Industrial } \\
\text { Estate }\end{array}$} & \multicolumn{2}{|c|}{$\begin{array}{c}\text { Al Dulayl } \\
\text { Industrial } \\
\text { Park }\end{array}$} & \multicolumn{2}{|c|}{$\begin{array}{c}\text { Al } \\
\text { Hussein } \\
\text { Bin } \\
\text { Abdullah } \\
\text { II (Karak) }\end{array}$} & \multicolumn{2}{|c|}{$\begin{array}{c}\text { Cyber City } \\
\text { Park }\end{array}$} & \multicolumn{2}{|c|}{ Total } \\
\hline & No. & $(\%)$ & No. & $(\%)$ & No. & $(\%)$ & No. & $(\%)$ & No. & $(\%)$ & No. & $(\%)$ \\
\hline Yes & 14 & 87.5 & 7 & 77.8 & 8 & 88.9 & 2 & 100 & 2 & 100 & 33 & 86.8 \\
\hline No & 2 & 12.5 & 2 & 22.2 & 1 & 11.1 & 0 & 0.0 & 0 & 0.0 & 5 & 13.2 \\
\hline Total & 16 & 100 & 9 & 100 & 9 & 100 & 2 & 100 & 2 & 100 & 38 & 100 \\
\hline \multicolumn{13}{|c|}{ Difficulties with Local Employees } \\
\hline $\begin{array}{l}\text { Difficulties to find local } \\
\text { Employees }\end{array}$ & No. & $(\%)$ & No. & $(\%)$ & No. & $(\%)$ & No. & $(\%)$ & No. & $(\%)$ & No. & $(\%)$ \\
\hline Yes & 12 & 75 & 6 & 67 & 8 & 89 & 2 & 100 & 2 & 100 & 30 & 78.9 \\
\hline No & 4 & 25 & 3 & 33 & 1 & 11 & 0 & 0 & 0 & 0 & 8 & 21.1 \\
\hline Total & 16 & 100 & 9 & 100 & 9 & 100 & 2 & 100 & 2 & 100 & 38 & 100 \\
\hline Transfer of Employees & No. & $(\%)$ & No. & $(\%)$ & No. & $(\%)$ & No. & $(\%)$ & No. & $(\%)$ & No. & $(\%)$ \\
\hline Yes & 14 & 87.5 & 7 & 77.8 & 7 & 77.8 & 1 & 50.0 & 2 & 100 & 31 & 81.6 \\
\hline No & 2 & 12.5 & 2 & 22.2 & 2 & 22.2 & 1 & 50.0 & 0 & 0.0 & 7 & 18.4 \\
\hline Total & 16 & 100 & 9 & 100 & 9 & 100 & 2 & 100 & 2 & 100 & 38 & 100 \\
\hline $\begin{array}{l}\text { If Local Employees were } \\
\text { Unemployed }\end{array}$ & No. & $(\%)$ & No. & $(\%)$ & No. & (\%) & No. & $(\%)$ & No. & (\%) & No. & $(\%)$ \\
\hline Yes & 15 & 93.8 & 8 & 88.9 & 9 & 100 & 2 & 100 & 2 & 100 & 36 & 94.7 \\
\hline No & 1 & 6.3 & 1 & 11.1 & 0 & 0 & 0 & 0 & 0 & 0 & 2 & 5.3 \\
\hline Total & 16 & 100 & 9 & 100 & 9 & 100 & 2 & 100 & 2 & 100 & 38 & 100 \\
\hline
\end{tabular}

Source: Field Research 
ii.Cost of Production: This was the second most common constraint that QIZs companies experienced. Some of the companies stressed the increase of the cost of production during the last years, owing to changes in laws and the opening of new zones in other countries with better infrastructure or lower wages. On average, operational costs make up around 55 percent of the cost of production (wages 34, work and resident fees 8 , rent 8 , and transportation 5 percent) for more details see table 5.10. Some investors remarked that in the medium-term Jordan will no longer be competitive in the international market compared to countries such as Egypt, India, Sir Lanka, and Pakistan unless the government takes real measures towards reducing operational costs. Around two thirds (66 percent) of the companies considered the increase in their cost of production a threat to their future existence in Jordan. According to the investors, the main factors that hindered their movement to other countries were: 1) the unclear and unstable political situation in other countries, 2) the requirements concerning labor that investors must fulfill in Egypt. However, as many investors stated, the government should implement policies to keep the available investors in the QIZs, because the increase in production cost might make it difficult to attract new investors or even to keep them operational. Table 5.10 depicts the main constraints and average cost of production for the companies working in the QIZs.

Table 5.10: Constraints in Production

\begin{tabular}{|c|c|c|c|c|c|c|c|c|c|c|c|c|}
\hline \multirow[b]{2}{*}{ Constraints in Production } & \multicolumn{2}{|c|}{$\begin{array}{c}\text { Al } \\
\text { Tajamouat } \\
\text { Industrial } \\
\text { City }\end{array}$} & \multicolumn{2}{|c|}{$\begin{array}{c}\text { Al Hassan } \\
\text { Industrial } \\
\text { Estate }\end{array}$} & \multicolumn{2}{|c|}{$\begin{array}{c}\text { Al Dulayl } \\
\text { Industrial } \\
\text { Park }\end{array}$} & \multicolumn{2}{|c|}{$\begin{array}{l}\text { Al Hussein } \\
\text { Bin } \\
\text { Abdullah } \\
\text { II (Karak) }\end{array}$} & \multicolumn{2}{|c|}{$\begin{array}{l}\text { Cyber City } \\
\text { Park }\end{array}$} & \multicolumn{2}{|c|}{ Total } \\
\hline & No. & $(\%)$ & No. & $(\%)$ & No. & $(\%)$ & No. & $(\%)$ & No. & $(\%)$ & No. & $(\%)$ \\
\hline Yes & 14 & 87.5 & 6 & 66.7 & 4 & 44.4 & 0 & 0.0 & 1 & 50 & 25 & 65.8 \\
\hline No & 2 & 12.5 & 3 & 33.3 & 5 & 55.6 & 2 & 100 & 1 & 50 & 13 & 34.2 \\
\hline Total & 16 & 100 & 9 & 100 & 9 & 100 & 2 & 100 & 2 & 100 & 38 & 100 \\
\hline
\end{tabular}

Average Cost of Production

\begin{tabular}{|l|c|c|c|c|c|c|}
\hline \multicolumn{1}{|c|}{ Average Cost of Production } & $(\%)$ & $(\%)$ & $(\%)$ & $(\%)$ & $(\%)$ & $(\%)$ \\
\hline Wages & 34.0 & 35.0 & 34.0 & n.a & 25.0 & 32.0 \\
\hline Resident Permission & 8.0 & 8.0 & 7.0 & n.a & 8.0 & 7.8 \\
\hline Transportation & 5.0 & 6.0 & 5.0 & n.a & 5.0 & 5.3 \\
\hline Raw Materials & 45.0 & 45.0 & 46.0 & n.a & 55.0 & 47.8 \\
\hline Rent & 8.0 & 6.0 & 8.0 & n.a & 7.0 & 7.3 \\
\hline Total & $\mathbf{1 0 0}$ & $\mathbf{1 0 0}$ & $\mathbf{1 0 0}$ & n.a & $\mathbf{1 0 0}$ & $\mathbf{1 0 0}$ \\
\hline \multicolumn{7}{|r|}{}
\end{tabular}

Source: Field Research

Note: n.a denote to not available

iii.Government Regulations: Government regulations were ranked as the third largest problem facing companies in Jordan's QIZs. In particular, government regulations 
involving employing foreign workers, custom procedures, and changing laws seem to affect investors' sustainability. These problems should be made subject to a specific study in order to assess how the system and its methods could be modified so as to be more supportive of QIZ companies. Instead, investors perceive government regulations as contrary to their business interests. For example, some companies complained about the increase in the minimum wage by the government from US\$120 to US\$135. They stressed that they would prefer the government to increase the minimum wage for local employees only and not for foreign employees, as the latter already cost investors more than local employees. The government policy is concerned mainly with increasing minimum wages to enhance standards of living for local employees and provide them the incentive to participate in the labor market.

Table 5.11: Constraints in Government Regulations

\begin{tabular}{|c|c|c|c|c|c|c|c|c|c|c|c|c|}
\hline \multirow[b]{2}{*}{$\begin{array}{l}\text { Constraints in Government } \\
\text { Regulations }\end{array}$} & \multicolumn{2}{|c|}{$\begin{array}{c}\text { Al } \\
\text { Tajamouat } \\
\text { Industrial } \\
\text { City }\end{array}$} & \multicolumn{2}{|c|}{$\begin{array}{l}\text { Al Hassan } \\
\text { Industrial } \\
\text { Estate }\end{array}$} & \multicolumn{2}{|c|}{$\begin{array}{c}\text { Al Dulayl } \\
\text { Industrial } \\
\text { Park }\end{array}$} & \multicolumn{2}{|c|}{$\begin{array}{l}\text { Al Hussein } \\
\text { Bin } \\
\text { Abdullah } \\
\text { II (Karak) }\end{array}$} & \multicolumn{2}{|c|}{$\begin{array}{l}\text { Cyber City } \\
\text { Park }\end{array}$} & \multicolumn{2}{|c|}{ Total } \\
\hline & No. & (\%) & No. & (\%) & No. & (\%) & No. & (\%) & No. & $(\%)$ & No. & (\%) \\
\hline Yes & 12 & 75.0 & 5 & 55.6 & 4 & 44.4 & 0 & 0.0 & 1 & 50 & 22 & 57.9 \\
\hline No & 4 & 25.0 & 4 & 44.4 & 5 & 55.6 & 2 & 100 & 1 & 50 & 16 & 42.1 \\
\hline Total & 16 & 100 & 9 & 100 & 9 & 100 & 2 & 100 & 2 & 100 & 38 & 100 \\
\hline
\end{tabular}

Source: Field Research

iv.Transportation: This was the fourth most common constraint facing QIZs companies as reported in the survey. There are two main problems investors face in the QIZs related to transportation. The first problem is the delay in exporting manufactured products to the US market on time, and the second problem is the delay when importing raw materials. These problems were faced by investors when exporting or importing via the Aqaba port. Some companies indicated that they were starting to transport their products by air to the US market instead. Others pointed out that they used Abu Dhabi and Haifa ports. According to the respondents, the main reasons to use the Haifa port or flights for transporting products to the US market instead of Aqaba port is due to the ease of procedures and the shortness of handling-time. According to Jordanian officials, solutions to the problems facing Aqaba port are now underway. About one third (34.2 percent) of the sample companies felt that transportation was problematic to them, while the remaining two thirds (65.8 percent) considered it not a big problem. This is because 
most companies start to use other alternatives in order to meet their needs. In most cases, the mother company is responsible for the arrangement of export and imports via QIZs. Table 5.12 highlights the main constraint and the approximate freight price and transit time from Aqaba and Haifa port to the USA.

Table 5.12: Constraint in Transportation

\begin{tabular}{|c|c|c|c|c|c|c|c|c|c|c|c|c|}
\hline \multirow[b]{2}{*}{ Constraint in Transportation } & \multicolumn{2}{|c|}{$\begin{array}{c}\text { Al } \\
\text { Tajamouat } \\
\text { Industrial } \\
\text { City } \\
\end{array}$} & \multicolumn{2}{|c|}{$\begin{array}{l}\text { Al Hassan } \\
\text { Industrial } \\
\text { Estate }\end{array}$} & \multicolumn{2}{|c|}{$\begin{array}{c}\text { Al Dulayl } \\
\text { Industrial } \\
\text { Park }\end{array}$} & \multicolumn{2}{|c|}{$\begin{array}{l}\text { Al Hussein } \\
\text { Bin } \\
\text { Abdullah } \\
\text { II (Karak) }\end{array}$} & \multicolumn{2}{|c|}{$\begin{array}{l}\text { Cyber City } \\
\text { Park }\end{array}$} & \multicolumn{2}{|c|}{ Total } \\
\hline & No. & $(\%)$ & No. & $(\%)$ & No. & $(\%)$ & No. & $(\%)$ & No. & $(\%)$ & No. & $(\%)$ \\
\hline Yes & 7 & 43.8 & 2 & 22.2 & 1 & 11.1 & 1 & 50.0 & 2 & 100 & 13 & 34.2 \\
\hline No & 9 & 56.3 & 7 & 77.8 & 8 & 88.9 & 1 & 50.0 & 0 & 0.0 & 25 & 65.8 \\
\hline Total & 16 & 100 & 9 & 100 & 9 & 100 & 2 & 100 & 2 & 100 & 38 & 100 \\
\hline \multicolumn{13}{|c|}{ Approximate Freight Price and Transit Time } \\
\hline From & \multicolumn{3}{|c|}{ To } & \multicolumn{3}{|c|}{$\begin{array}{c}20 \text { Foot } \\
\text { Container }\end{array}$} & \multicolumn{3}{|c|}{$\begin{array}{c}40 \text { Foot } \\
\text { Container }\end{array}$} & \multicolumn{3}{|c|}{ Time / days } \\
\hline Jordan (Aqaba Port) & \multicolumn{3}{|c|}{ New York } & \multicolumn{3}{|c|}{ US\$ 2100} & \multicolumn{3}{|c|}{ US\$ 2950} & \multicolumn{3}{|c|}{30 days } \\
\hline Israel (Haifa Port) & \multicolumn{3}{|c|}{ New York } & \multicolumn{3}{|c|}{ US\$ 2050} & \multicolumn{3}{|c|}{ US\$ 2775} & \multicolumn{3}{|c|}{18 days } \\
\hline
\end{tabular}

Sources: Field Research and Al Dulayl Industrial Park Guide

v.Input Requirements: Table 5.13 reveals the main constraint in input and raw material in addition to the preferred agreement to work under it by investors. About one third of the sample companies said that they experienced problems with the fulfillment of the required inputs from Israel (the 7 - 8 percent) to meet the value added requirements. Respondents complained that they are obliged to buy products from Israel even though its products are very expensive compared to other countries' products. As a result, 58 percent of the respondents indicated that they prefer to work under FTA agreements in order to avoid dealing with Israeli companies and instead have the choice to import raw materials and inputs from any where in the world with cheap prices and good quality.

Table 5.13: Constraints in Input and Raw Material

\begin{tabular}{|c|c|c|c|c|c|c|c|c|c|c|c|c|c|}
\hline \multirow{2}{*}{\multicolumn{2}{|c|}{$\begin{array}{l}\text { Constraints In Input and Raw } \\
\text { Material }\end{array}$}} & \multicolumn{2}{|c|}{$\begin{array}{c}\text { Al } \\
\text { Tajamouat } \\
\text { Industrial } \\
\text { City } \\
\end{array}$} & \multicolumn{2}{|c|}{$\begin{array}{l}\text { Al Hassan } \\
\text { Industrial } \\
\text { Estate }\end{array}$} & \multicolumn{2}{|c|}{$\begin{array}{c}\text { Al Dulayl } \\
\text { Industrial } \\
\text { Park }\end{array}$} & \multicolumn{2}{|c|}{$\begin{array}{c}\text { Al Hussein } \\
\text { Bin } \\
\text { Abdullah } \\
\text { II (Karak) } \\
\end{array}$} & \multicolumn{2}{|c|}{$\begin{array}{l}\text { Cyber City } \\
\text { Park }\end{array}$} & \multicolumn{2}{|c|}{ Total } \\
\hline & & No. & $(\%)$ & No. & $(\%)$ & No. & $(\%)$ & No. & $(\%)$ & No. & $(\%)$ & No. & $(\%)$ \\
\hline \multicolumn{14}{|c|}{ In Input and Raw Material } \\
\hline Yes & & 5 & 31.3 & 1 & 11.1 & 4 & 44.4 & 2 & 100 & 0 & 0.0 & 12 & 31.6 \\
\hline No & & 11 & 68.8 & 8 & 88.9 & 5 & 55.6 & 0 & 0.0 & 2 & 100 & 26 & 68.4 \\
\hline Total & & 16 & 100 & 9 & 100 & 9 & 100 & 2 & 100 & 2 & 100 & 38 & 100 \\
\hline \multicolumn{14}{|c|}{ QIZs Vs. FTA } \\
\hline Preferred Agreement & No. & $(\%)$ & No. & $(\%)$ & No. & $(\%)$ & $\bar{N}$ & & & No. & $(\%)$ & No. & $(\%)$ \\
\hline$\overline{\mathrm{QIZs}}$ & 4 & 25.0 & 6 & 66.7 & 3 & 33.3 & 1 & & & 2 & 100 & 16 & 42.1 \\
\hline FTA & 12 & 75.0 & 3 & 33.3 & 6 & 66.7 & 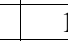 & & & 0 & 0.0 & 22 & 57.9 \\
\hline Total & 16 & 100 & 9 & $\mathbf{0}$ & 9 & 100 & 2 & & & 2 & 100 & 38 & 100 \\
\hline
\end{tabular}

Source: Field Research

Note: FTA is related to the Free Trade Agreement with the USA 


\subsection{The Start-Up of the Companies}

In this section we will discuss the start-up capital of the companies in our sample and the principal source of the financial resources. This will help clarify some of the potential factors affecting the companies' relationships with the local economy.

\subsubsection{Initial Funding for the Companies}

Table 5.14 shows the start-up capital of the sample companies, according to the interviewees view. Around 30 percent of the sample companies got start-up funding of more than US\$ 5 million, while more than half of the companies was started up with capital sums less than US\$2.5 million. Relatively few companies were started with US\$ 2.5 to 5.0 million, indicating that the nature of QIZs attracts either small players or very large players, but not much in between.

Table 5.14: The Start up of the Company

\begin{tabular}{|c|c|c|c|c|c|c|c|c|c|c|c|c|}
\hline \multirow[b]{2}{*}{ Investment Capital in US\$ } & \multicolumn{2}{|c|}{$\begin{array}{c}\text { Al } \\
\text { Tajamouat } \\
\text { Industrial } \\
\text { City }\end{array}$} & \multicolumn{2}{|c|}{$\begin{array}{c}\text { Al Hassan } \\
\text { Industrial } \\
\text { Estate }\end{array}$} & \multicolumn{2}{|c|}{$\begin{array}{c}\text { Al Dulayl } \\
\text { Industrial } \\
\text { Park }\end{array}$} & \multicolumn{2}{|c|}{$\begin{array}{c}\text { Al } \\
\text { Hussein } \\
\text { Bin } \\
\text { Abdullah } \\
\text { II (Karak) }\end{array}$} & \multicolumn{2}{|c|}{$\begin{array}{c}\text { Cyber City } \\
\text { Park }\end{array}$} & \multicolumn{2}{|c|}{ Total } \\
\hline & No. & $(\%)$ & No. & $(\%)$ & No. & $(\%)$ & No. & $(\%)$ & No. & $(\%)$ & No. & $(\%)$ \\
\hline Up to 1 Mill & 6 & 37.5 & 0 & 0 & 3 & 33 & 0 & 0 & 0 & 0 & 9 & 23.7 \\
\hline From 1 Mill to 2,5 Mill & 5 & 31.3 & 4 & 44 & 2 & 22 & 0 & 0 & 1 & 50 & 12 & 31.6 \\
\hline From 2,5 Mill to 5 Mill & 3 & 18.8 & 0 & 0 & 0 & 0 & 1 & 50 & 1 & 50 & 5 & 13.2 \\
\hline More than 5 Mill & 2 & 12.5 & 5 & 56 & 4 & 44 & 1 & 50 & 0 & 0 & 12 & 31.6 \\
\hline Total & 16 & 100 & 9 & 100 & 9 & 100 & 2 & 100 & 2 & 100 & 38 & 100 \\
\hline
\end{tabular}

Source: Field Research

\subsubsection{Financial Resources for Staring-Up the company}

Table 5.15 shows the financial resources available to the companies. The financing of companies operating in QIZs was expected to be mainly from bank borrowing, selffinance, or partners and investors. The interviewees were asked about their financial resources for the start-up. The majority of the sample companies indicated that their main source of funds was self-finance. It can be seen from Table 5.15 that self-finance accounts for 58 percent of the sample companies as the only source for start-up capital. Around 20 percent of respondents were reliant on partners and investors for start-up. Less than 3 percent relied on bank borrowing alone, though about 18 percent used bank borrowing along with other sources of funds. The low share of bank borrowing reflects commercial bank’s reluctance to provide loans to the QIZs due to the high of risk. 
Table 5.15: Main Financial Resources

\begin{tabular}{|c|c|c|c|c|c|c|c|c|c|c|c|c|}
\hline \multirow[b]{2}{*}{ The Main Financial Resources } & \multicolumn{2}{|c|}{$\begin{array}{c}\text { Al } \\
\text { Tajamouat } \\
\text { Industrial } \\
\text { City }\end{array}$} & \multicolumn{2}{|c|}{$\begin{array}{c}\text { Al Hassan } \\
\text { Industrial } \\
\text { Estate }\end{array}$} & \multicolumn{2}{|c|}{$\begin{array}{c}\text { Al Dulayl } \\
\text { Industrial } \\
\text { Park }\end{array}$} & \multicolumn{2}{|c|}{$\begin{array}{c}\text { Al } \\
\text { Hussein } \\
\text { Bin } \\
\text { Abdullah } \\
\text { II (Karak) }\end{array}$} & \multicolumn{2}{|c|}{$\begin{array}{c}\text { Cyber City } \\
\text { Park }\end{array}$} & \multicolumn{2}{|c|}{ Total } \\
\hline & No. & $(\%)$ & No. & $(\%)$ & No. & $(\%)$ & No. & $(\%)$ & No. & $(\%)$ & No. & $(\%)$ \\
\hline Self Finance & 7 & 43.8 & 6 & 66.7 & 7 & 77.8 & 1 & 50 & 1 & 50 & 22 & 57.9 \\
\hline Bank borrowing & 0 & 0.0 & 1 & 11.1 & 0 & 0 & 0 & 0 & 0 & 0 & 1 & 2.6 \\
\hline Self finance and Bank Borrowing & 3 & 18.8 & 1 & 11.1 & 1 & 11.1 & 0 & 0 & 0 & 0 & 5 & 13.2 \\
\hline Partners and Investors & 4 & 25.0 & 1 & 11.1 & 1 & 11.1 & 1 & 50 & 1 & 50 & 8 & 21.1 \\
\hline $\begin{array}{l}\text { Partners and Investors and Bank } \\
\text { Borrowing }\end{array}$ & 2 & 12.5 & 0 & 0.0 & 0 & 0 & 0 & 0 & 0 & 0 & 2 & 5.3 \\
\hline Total & 16 & 100 & 9 & 100 & 9 & 100 & 2 & 100 & 2 & 100 & 38 & 100 \\
\hline
\end{tabular}

Source: Field Research

\subsection{The Economic Impacts of the QIZs}

This section investigates the effects of QIZs on the local economy from every possible aspect such as employment impact, technology impact, foreign exchange impact, balance of payment impact, multiplier impact, and so on. The main results are based on responses given by the interviewees and some external data (i.e. MOP, and MIT data).

\subsubsection{The QIZs Impacts}

The most important effects of the QIZs can be seen from table 5.16. The interviewees were asked whether establishing the QIZs led to any of the following: the introduction of innovative management practice, the development of new products or services, the development of new processes, cutting-edge technology, the incitation of new production technology for the first time, and new marketing and distribution strategies. Sixty-one percent of the companies in the sample indicated that QIZs led to the introduction of innovative management practices, while 42 percent said that QIZs led to the development of new products or services. Significant percentages of respondents claimed that operating in the QIZs led to new development processes, the application of new technology or leading-edge technologies, and the introduction of new marketing strategies.

In the textile and garment industry in Jordan, around two-thirds of companies said the QIZs had led to the introduction of new management practices. This is because the Jordanian managers benefited from foreign investors' management experience. On the other hand, as some interviewees indicated Jordanian employees working at the administrative level in the companies already have management skills and for this these companies hired them. 
Developing new products were agreed by 42 percent, while developing new processes only 39 percent. These lowest rates are reasonable, as textile and garment industry in Jordan are found before the creating of QIZ zones. The main difference between characteristics of textile and garment industry in Jordan before establishing the QIZs and after establishing them is that formerly there was no mass production, while afterwards the QIZs were characterized by labor intensive and mass production. For this some investors consider the textile and garment industry to be new to the country. The cutting-edge technology was reported by more than one third of the respondents (34 percent). This is due to the multiprocess and technical systems necessary in this sector. Those respondents agreed that QIZs companies attract new technology to the country, particularly in the area of using computerized systems for printing, using huge machines in the process of cutting, embroidery, and washing.

In general, the production stages of this industry in Jordan is only concentrated upon the labor-intensive work such as cutting, trimming, and making (CTM) as the majority of investors indicated. This fact reflects the high proportional rate of respondents (66 percent) who agreed that QIZs did not lead to cutting-edge technology or transfer technology to the country at all. This is because all QIZs companies focused on producing light manufacturing products such as textiles and apparel.

Regarding the effects of introducing new marketing strategies by the companies in the QIZs, only 32 percent of the companies agreed that QIZs led to introduce new marketing strategies. This low rate reflects the fact that most of the companies in the QIZs are not responsible for marketing, as the mother company is responsible for marketing. In all cases, it seems that the mother company arranges everything such as orders to be produced by QIZs companies, the marketing strategy, and the time of delivery. In addition, most technical employees and administrative managers were from the investor's country of origin, which also helped to limit transferring any experience and knowledge to local employees. 
Table 5.16: The Economic Impact

\begin{tabular}{|c|c|c|c|c|c|c|c|c|c|c|c|c|}
\hline \multirow[b]{2}{*}{$\begin{array}{l}\text { The Effects of the QIZ } \\
\text { Companies on the Economy }\end{array}$} & \multicolumn{2}{|c|}{$\begin{array}{c}\text { Al } \\
\text { Tajamouat } \\
\text { Industrial } \\
\text { City }\end{array}$} & \multicolumn{2}{|c|}{$\begin{array}{c}\text { Al Hassan } \\
\text { Industrial } \\
\text { Estate }\end{array}$} & \multicolumn{2}{|c|}{$\begin{array}{c}\text { Al Dulayl } \\
\text { Industrial } \\
\text { Park }\end{array}$} & \multicolumn{2}{|c|}{$\begin{array}{c}\text { Al } \\
\text { Hussein } \\
\text { Bin } \\
\text { Abdullah } \\
\text { II (Karak) }\end{array}$} & \multicolumn{2}{|c|}{$\begin{array}{l}\text { Cyber City } \\
\text { Park }\end{array}$} & \multicolumn{2}{|c|}{ Total } \\
\hline & No. & $(\%)$ & No. & $(\%)$ & No. & $(\%)$ & No. & $(\%)$ & No. & $(\%)$ & No. & $(\%)$ \\
\hline \multicolumn{13}{|l|}{$\begin{array}{l}\text { Introduce Innovative } \\
\text { Management Practices }\end{array}$} \\
\hline Yes & 12 & 75 & 4 & 44 & 4 & 44 & 2 & 100 & 1 & 50 & 23 & 61 \\
\hline No & 4 & 25 & 5 & 56 & 5 & 56 & 0 & 0 & 1 & 50 & 15 & 39 \\
\hline Total & 16 & 100 & 9 & 100 & 9 & 100 & 2 & 100 & 2 & 100 & 38 & 100 \\
\hline \multicolumn{13}{|l|}{ Develop New Products } \\
\hline Yes & 8 & 50 & 2 & 22 & 4 & 44 & 1 & 50 & 1 & 50 & 16 & 42 \\
\hline No & 8 & 50 & 7 & 78 & 5 & 56 & 1 & 50 & 1 & 50 & 22 & 58 \\
\hline Total & 16 & 100 & 9 & 100 & 9 & 100 & 2 & 100 & 2 & 100 & 38 & 100 \\
\hline \multicolumn{13}{|l|}{ Develop New Process } \\
\hline Yes & 8 & 50 & 1 & 11 & 4 & 44 & 2 & 100 & 0 & 0 & 15 & 39 \\
\hline No & 8 & 50 & 8 & 89 & 5 & 56 & 0 & 0 & 2 & 100 & 23 & 61 \\
\hline Total & 16 & 100 & 9 & 100 & 9 & 100 & 2 & 100 & 2 & 100 & 38 & 100 \\
\hline \multicolumn{13}{|l|}{$\begin{array}{l}\text { Apply New Production } \\
\text { Technology }\end{array}$} \\
\hline Yes & 6 & 37 & 2 & 22 & 3 & 33 & 2 & 100 & 0 & 0 & 13 & 34 \\
\hline No & 10 & 63 & 7 & 78 & 6 & 67 & 0 & 0 & 2 & 100 & 25 & 66 \\
\hline Total & 16 & 100 & 9 & 100 & 9 & 100 & 2 & 100 & 2 & 100 & 38 & 100 \\
\hline \multicolumn{13}{|l|}{$\begin{array}{l}\text { Introduce New Marketing } \\
\text { Strategies }\end{array}$} \\
\hline Yes & 4 & 25 & 2 & 22 & 3 & 33 & 1 & 50 & 2 & 100 & 12 & 32 \\
\hline No & 12 & 75 & 7 & 78 & 6 & 67 & 1 & 50 & 0 & 0 & 26 & 68 \\
\hline Total & 16 & 100 & 9 & 100 & 9 & 100 & 2 & 100 & 2 & 100 & 38 & 100 \\
\hline
\end{tabular}

Source: Field Research

\subsubsection{The Effects of QIZs on Employment}

\subsubsection{Employment}

Employment is one of the most important measurements of the economic impact of QIZs companies this is because of high unemployment rate that Jordan faces. In the year 2004 the unemployment rate in Jordan has considered high and stood overall at about 12.5 percent and affected young people in particular: 60 percent of all unemployed people were below the age of 25, while for young women the rate was 82 percent. According to the Jordan Human Development Report 2000, the causes of unemployment of young people were (1) common reluctance among educated Jordanians to take manual labor jobs, (2) recurrent economic slow-down since the 1980s, (3) skills of graduates do not meet needs of the economic sector, (4) poor in-job-training and continuous education. Moreover, other reasons were related to the imbalances between the input and output of the education system, since number of new graduates entering the labor force each year is between 45,000 - 65,000 new employees, the social and cultural attitude against low wages jobs and 
the high number of foreign workers in the country. Nevertheless, the unofficial rate of unemployment is higher and range between 25 - 30 percent of labor force (see table 5.17).

Table 5.17: Development of Labor Force and Unemployment 1999 - 2004

\begin{tabular}{|l|c|c|c|c|c|c|}
\hline & $\mathbf{1 9 9 9}$ & $\mathbf{2 0 0 0}$ & $\mathbf{2 0 0 1}$ & $\mathbf{2 0 0 2}$ & $\mathbf{2 0 0 3}$ & $\mathbf{2 0 0 4}$ \\
\hline Labor force & 910.000 & 1.000 .000 & 1.150 .000 & 1.250 .000 & 1.360 .000 & 1.410 .000 \\
\hline Unemployment & 121.940 & 137.000 & 169.050 & 191.250 & 197.200 & 176.250 \\
\hline Unemployment rate \% & 13.4 & 13.7 & 14.7 & 15.3 & 14.5 & 12.5 \\
\hline Unofficial rate \% & $25-30$ & $25-30$ & $25-30$ & $25-30$ & $25-30$ & $25-30$ \\
\hline
\end{tabular}

Sources: World Fact Book different issues, World Bank, Ministry of Planning, and Author calculation.

\subsubsection{Job Created by QIZs Companies}

Due to the important role of the QIZs companies in creating employment opportunities, the interviewees were asked about the jobs that were created by the company during the early stage of the establishment of the project. Jobs 'created' are shown in table 5.18. This table shows that around 40 percent of the employment in the QIZs was created for local employees, while 60 percent of the jobs were created for foreign employees. It is worth mentioning here that the proportion of local employees in the companies differs from one company to another. In some companies the minimum share of local employees was registered at around 6.6 percent in a company located in Al Dulayl Industrial Park, while the maximum share of local employees registered around 100 percent in a company located in Al Hassan Industrial Estate. The interesting result that has been found is that, if the company is managed and ruled by a local investor, the vast majority of employees will be locals and if it is managed by a foreign investors, the majority of employees will be foreign. Moreover, this result reflects the fact that local employees are capable of handling work in the garment and apparel industries, as opposed to the thinking of many investors that local employees were not willing to work or not productive. In fact, local employees can retain work in QIZs if they are provided with good incentives and good work conditions as indicated by those investors who employed the vast majority of employees from among locals. Also this result suggests that QIZs have a greater ability to create jobs for local employees than what they do now, in a way that they could be considered an engine for creating jobs greater than other sectors in the economy. In general, government policy should concentrate upon enhancing work-conditions for local employees through

providing them with good vocational training suiting the needs of the companies and giving them more incentives to stay at work (for more details see figure 5.5). 
Table 5.18: Job Created by QIZs Companies

\begin{tabular}{|c|c|c|c|c|c|c|c|c|c|c|c|c|}
\hline \multirow[b]{2}{*}{ Job Created } & \multicolumn{2}{|c|}{$\begin{array}{c}\text { Al } \\
\text { Tajamouat } \\
\text { Industrial } \\
\text { City }\end{array}$} & \multicolumn{2}{|c|}{$\begin{array}{c}\text { Al Hassan } \\
\text { Industrial } \\
\text { Estate }\end{array}$} & \multicolumn{2}{|c|}{$\begin{array}{l}\text { Al Dulayl } \\
\text { Industrial } \\
\text { Park }\end{array}$} & \multicolumn{2}{|c|}{$\begin{array}{c}\text { Al Hussein } \\
\text { Bin } \\
\text { Abdullah } \\
\text { II (Karak) }\end{array}$} & \multicolumn{2}{|c|}{$\begin{array}{c}\text { Cyber City } \\
\text { Park }\end{array}$} & \multicolumn{2}{|c|}{ Total } \\
\hline & No. & $(\%)$ & No. & $(\%)$ & No. & $(\%)$ & No. & $(\%)$ & No. & $(\%)$ & No. & $(\%)$ \\
\hline Foreign & 4555 & 61.3 & 1488 & 38.4 & 3956 & 71.9 & 390 & 60.9 & 390 & 73.6 & 10779 & 60.0 \\
\hline Local & 2877 & 38.7 & 2382 & 61.6 & 1545 & 28.1 & 250 & 39.1 & 140 & 26.4 & 7194 & 40.0 \\
\hline Total & 7432 & 100 & 3870 & 97 & 5501 & 94 & 640 & 100 & 530 & 100 & 17973 & 100 \\
\hline \multicolumn{13}{|c|}{ Share of Local Employees } \\
\hline Minimum Share & \multicolumn{2}{|c|}{14.3} & \multicolumn{2}{|c|}{40.0} & \multicolumn{2}{|c|}{6.6} & \multicolumn{2}{|c|}{31.8} & \multicolumn{2}{|c|}{14.3} & \multicolumn{2}{|c|}{-} \\
\hline Maximum Share & \multicolumn{2}{|c|}{95.7} & \multicolumn{2}{|c|}{100.0} & \multicolumn{2}{|c|}{50.0} & \multicolumn{2}{|c|}{55.0} & \multicolumn{2}{|c|}{50.0} & \multicolumn{2}{|c|}{ - } \\
\hline
\end{tabular}

Source: Field Research

\subsubsection{The Effects of the QIZs on Rural Area}

Establishing QIZs help to create jobs for local unemployed persons, particularly in the rural areas where unemployment rate is very high. It seems that QIZs contribute positively in creating jobs for local employees and reducing the overall unemployment rate in the country (see table 5.17), and it allows a means of income for those employees to improve their standard of living. For many observers, QIZs are considered an engine for job creation in the country. Up to now, there are more than 50 companies operating in the QIZs, employing over 32,000 workers. The data is promising, but not as expected.

Table 5.19 shows the development of QIZs in creating jobs for local and foreign employees, total employment in QIZs started with 5,931 employees in the year 2000, and reached around 32,436 employees in the year 2005. Total number of local employees employed by those companies’ shows significant increase, between the years $2000-2003$ with an average increases about 5,315 employees annually. Numbers began with 2,597 employees in 2000 and jumped to 12,494 employees in 2003. Then, the number of local employees starts to decrease dramatically to 12,141 and 11,138 for the years 2004 and 2005 respectively. At the same time, while numbers of local employees declined, numbers of foreign employees witnessed an increase, in all the years. This is because of the instability of local employees on one hand and the difficulty in finding and hiring local employees on the other hand, which helped to import more foreign workers and increased their number (for more details see figure 5.6). Nevertheless, the progress of local employment in the QIZs is opposite to expectations. This is because local employees should substitute foreign employees, at least after few years from working in the QIZs, as government policy stipulated and according to its aims. According to the Jordanian labor law, the permitted percentage of foreign labor should not exceed 30 percent during the first 
year and must decrease gradually in the second and third year to 25 percent and 15 percent respectively. However, the results of the study are contrary to the provisions of the Jordanian labor law since there is an over-reliance on foreign labor against local counterparts as shown in table 5.19. The main reason for the decline in the number of local employees is related to the high rate of turnover of local employees. In spite of the fact that 94.7 percent of local employees were unemployed before working in the QIZs, the field study shows that there were around 20 employees on average leaving their job every month in order to look for better chances and higher wages in other companies. On the whole, investors found themselves obliged to import foreign workers in order to make up for the shortage of local workers.

Table 5.19: Employment in QIZs Companies

\begin{tabular}{|c|c|c|c|c|c|c|c|c|c|c|c|c|}
\hline \multirow[b]{2}{*}{ Employment } & \multicolumn{2}{|c|}{$\begin{array}{c}\text { Al } \\
\text { Tajamouat } \\
\text { Industrial } \\
\text { City }\end{array}$} & \multicolumn{2}{|c|}{$\begin{array}{c}\text { Al Hassan } \\
\text { Industrial } \\
\text { Estate }\end{array}$} & \multicolumn{2}{|c|}{$\begin{array}{c}\text { Al Dulayl } \\
\text { Industrial } \\
\text { Park }\end{array}$} & \multicolumn{2}{|c|}{$\begin{array}{c}\text { Al Hussein } \\
\text { Bin } \\
\text { Abdullah } \\
\text { II (Karak) }\end{array}$} & \multicolumn{2}{|c|}{$\begin{array}{c}\text { Cyber City } \\
\text { Park }\end{array}$} & \multicolumn{2}{|c|}{ Total } \\
\hline & No. & $(\%)$ & No. & $(\%)$ & No. & $(\%)$ & No. & $(\%)$ & No. & $(\%)$ & No. & $(\%)$ \\
\hline \multicolumn{13}{|l|}{ Local Employees } \\
\hline 2000 & 750 & 3.8 & 1132 & 7.5 & 465 & 5.2 & 250 & 4.1 & 0 & 0.0 & 2597 & 5.0 \\
\hline 2001 & 1377 & 7.0 & 2121 & 14.0 & 1350 & 15.0 & 250 & 4.1 & 140 & 7.3 & 5238 & 10.1 \\
\hline 2002 & 3365 & 17.2 & 2825 & 18.6 & 1440 & 16.0 & 250 & 4.1 & 230 & 12.0 & 8110 & 15.7 \\
\hline 2003 & 5570 & 28.4 & 2989 & 19.7 & 1873 & 20.8 & 1762 & 29.2 & 300 & 15.7 & 12494 & 24.2 \\
\hline 2004 & 4698 & 24.0 & 2985 & 19.6 & 2076 & 23.1 & 1762 & 29.2 & 620 & 32.5 & 12141 & 23.5 \\
\hline 2005 & 3820 & 19.5 & 3140 & 20.7 & 1788 & 19.9 & 1770 & 29.3 & 620 & 32.5 & 11138 & 21.5 \\
\hline \multicolumn{13}{|l|}{ Foreign Employees } \\
\hline 2000 & 511 & 2.1 & 938 & 7.6 & 1495 & 6.4 & 390 & 6.7 & 0 & 0.0 & 3334 & 4.7 \\
\hline 2001 & 1235 & 5.0 & 1073 & 8.7 & 2666 & 11.4 & 390 & 6.7 & 390 & 8.8 & 5754 & 8.1 \\
\hline 2002 & 3519 & 14.1 & 1273 & 10.4 & 2694 & 11.5 & 390 & 6.7 & 550 & 12.4 & 8426 & 11.9 \\
\hline 2003 & 4866 & 19.5 & 1873 & 15.2 & 4466 & 19.1 & 1370 & 23.5 & 620 & 14.0 & 13195 & 18.6 \\
\hline 2004 & 7075 & 28.4 & 3260 & 26.5 & 5680 & 24.3 & 1370 & 23.5 & 1400 & 31.6 & 18785 & 26.5 \\
\hline 2005 & 7688 & 30.9 & 3880 & 31.6 & 6340 & 27.2 & 1920 & 32.9 & 1470 & 33.2 & 21298 & 30.1 \\
\hline \multicolumn{13}{|l|}{ Total Employment } \\
\hline 2000 & 1261 & 2.8 & 2070 & 7.5 & 1960 & 6.1 & 640 & 5.4 & 0 & 0.0 & 5931 & 4.8 \\
\hline 2001 & 2612 & 5.9 & 3194 & 11.6 & 4016 & 12.4 & 640 & 5.4 & 530 & 8.4 & 10992 & 9.0 \\
\hline 2002 & 6884 & 15.5 & 4098 & 14.9 & 4134 & 12.8 & 640 & 5.4 & 780 & 12.3 & 16536 & 13.5 \\
\hline 2003 & 10436 & 23.5 & 4862 & 17.7 & 6339 & 19.6 & 3132 & 26.4 & 920 & 14.5 & 25689 & 21.0 \\
\hline 2004 & 11773 & 26.5 & 6245 & 22.7 & 7756 & 24.0 & 3132 & 26.4 & 2020 & 31.9 & 30926 & 25.2 \\
\hline 2005 & 11508 & 25.9 & 7020 & 25.5 & 8128 & 25.1 & 3690 & 31.1 & 2090 & 33.0 & 32436 & 26.5 \\
\hline \multicolumn{13}{|c|}{ Share of Local and Foreign Employees in QIZs } \\
\hline Share of Employment & \multicolumn{2}{|c|}{ Share } & \multicolumn{2}{|c|}{ Share } & \multicolumn{2}{|c|}{ Share } & \multicolumn{2}{|c|}{ Share } & \multicolumn{2}{|c|}{ Share } & \multicolumn{2}{|c|}{ Share } \\
\hline \multicolumn{13}{|l|}{ Local Employees } \\
\hline 2000 & \multicolumn{2}{|c|}{59.5} & \multicolumn{2}{|c|}{54.7} & \multicolumn{2}{|c|}{23.7} & \multicolumn{2}{|c|}{39.1} & \multicolumn{2}{|c|}{0.0} & & \\
\hline 2001 & 52 & & 66 & & & & & & 26 & & & \\
\hline 2002 & 48 & & 68 & & & & & & 29 & & & \\
\hline 2003 & 53 & & 61 & & & & & & 32 & & & \\
\hline 2004 & 39 & & 47 & & & & & & 30 & & & \\
\hline 2005 & 33 & & 44 & & & & & & 29 & & & \\
\hline Foreign Employees & & & & & & & & & & & & \\
\hline 2000 & 40 & & 45 & & & & & & 0 & & & \\
\hline 2001 & 47 & & 33 & & & & & & 73 & & & \\
\hline 2002 & 51 & & 31 & & & & & & 70 & & & \\
\hline 2003 & 46 & & 38 & & & & & & 67 & & & \\
\hline 2004 & 60 & & 52 & & & & & & 69 & & & \\
\hline 2005 & 66 & & 55 & & & & & & 70 & & & \\
\hline
\end{tabular}




\subsubsection{Characteristics of Workers in the QIZs}

QIZs are described as labor intensive zones and its characteristics are similar to what is known now in the world as Economic Processing Zones. The main similarities between QIZs and other kinds of zones were in the following criteria: the heavy reliance on laborintensive products, female workers, skilled and unskilled labor, and wage costs. Following is a brief description of the main characteristics that have been found within the QIZs, which are similar to the other kinds of zones.

\subsection{Gender Composition}

Table 5.20 illustrates that companies operating in the QIZs have shown an overwhelming preference for employing young women. The study explore that the average share of working female to the total employment in the QIZs companies were higher than their male counterpart. The average proportion of female workers was found to be around 75 percent. This is because garment and textile industry is female intensive and women are preferred to men as employees by the QIZs companies. Also table 5.20 highlights that companies in the QIZs choose to hire female more than male for both local and foreign employees, the average share of foreign female was 79 percent, while for local female it was 70 percent. Some investors indicate that they prefer to hire local females more than their male counterpart, because the front lines of production units are managed by foreign females. According to a report published by the UNIDO in 1980, companies prefer to employ young females based on three main considerations: 1) women's wage are generally lower than male wages, 2) women are more productive than men, and 3) women are more willing and able to adapt to the monotony of operation.

Nevertheless, most of the females employed in the QIZs were young, with an average age of 18 - 25 years and with lower educational background. This is because the kind of jobs offered to them are easy and do not need high qualifications. Most of the jobs offered to the local employees were in cutting, trimming, backing, and sewing. Generally, the pattern of employing females in the QIZs is confined to the textile and garment industry, just as in Export Processing Zones this is the case with light manufacturing processes. This is accomplished without introducing any new products or even new technology. 
Table 5.20: Average Share of Women in QIZs

\begin{tabular}{|l|c|c|c|c|c|c|}
\hline & $\begin{array}{c}\text { Al } \\
\text { Tajamouat } \\
\text { Industrial } \\
\text { City }\end{array}$ & $\begin{array}{c}\text { Al Hassan } \\
\text { Industrial } \\
\text { Estate }\end{array}$ & $\begin{array}{c}\text { Al Dulayl } \\
\text { Industrial } \\
\text { Park }\end{array}$ & $\begin{array}{c}\text { Al } \\
\text { Hussein } \\
\text { Bin } \\
\text { Abdullah } \\
\text { II (Karak) }\end{array}$ & $\begin{array}{c}\text { Cyber City } \\
\text { Park }\end{array}$ & Total \\
\hline Average Share of Women & $(\%)$ & $(\%)$ & $(\%)$ & $(\%)$ & $(\%)$ & $(\%)$ \\
\hline \multicolumn{7}{|l|}{} \\
\hline Foreign Employees & $75 \%$ & $74 \%$ & $84 \%$ & $80 \%$ & $80 \%$ & $79 \%$ \\
\hline Local Employees & $74 \%$ & $60 \%$ & $84 \%$ & $80 \%$ & $50 \%$ & $70 \%$ \\
\hline
\end{tabular}

Source: Field Research

\subsection{Skilled and Unskilled Employees}

Labor in QIZs are characterized by various things. One of these characteristics concerns skilled and unskilled labors. According to some interviewees local labor is considered unskilled, while foreign labor apparently skilled. Only 5 percent of local employees in all QIZ companies were considered skilled, while the remainders were not skilled. Table 5.21 shows that unskilled employees in QIZs were over one third (34.8 percent) of the total workforce, whilst skilled labor registered around 65.2 percent. It is worth mentioning here that when factories start operation in the QIZs, it was agreed that 50 percent of employees were to be local employees and the rest foreigners. This is because most local employees do not enjoy the required skilled needed for textile jobs, in comparison to their foreign counterparts.

Nevertheless, the medium-term strategy followed by the government aimed towards the substitution of local employees with foreign employees through taking some actions as to increasing residency and work permit fees to foreign employees. According to this strategy, the cost of residency and work permit fees for foreign workers should be equal to US\$ 212 in the first year and then it should increase by US\$ 115 annually for every additional year. Despite this strategy the number of foreign employees still increased, as opposed to the number of local employees. The decline in the number of local employees as opposed to that of their foreign counterparts was due to two main factors. The first factor is related to the workers themselves, and the other one due to the companies and investors. In the first case, local workers played a big role in decreasing their number against the increasing number of foreign employees. This is because local employees were characterized by the following: a) the instability in the work, made clear by the high turnover of local employees which registered around 20 employees on average leaving per month, b) the disinclination to sustain this kind of job as a future career, because working in garments is 
considered socially-unacceptable in the Jordanian society, and c) the low wages offered to local employees compared to their foreign counterparts, also play the main role for determining their future sequences, as men are more demanding of financial remuneration than women. The second factor is related to the companies and investors. In this case investors participate the decline in number of local employees by applying the following procedures: 1) the nature of job offered to local employees by investors is naïve and with low productivity and value added, 2) companies in QIZs specialized in labor intensive jobs (textile and apparel) which do not need highly-qualified workers, and 3) companies offered minor jobs to local employees which limit technology transfer to them and made it difficult for them to increase their rigid salaries. Thus, from the following remarks we can draw the following outcomes: a) the technology transfer to local employees from QIZs companies is limited, and b) the instability of local employees to work for a long period is due to the minor job offered to them alongside with the low wages. The reason for the disparity of wages between local and foreigner employees is described in the next section.

Table 5.21: Number of Skilled and Unskilled Employees in 2004

\begin{tabular}{|l|c|c|c|c|c|c|c|c|c|c|c|c|}
\hline $\begin{array}{l}\text { Number of Skilled and } \\
\text { Unskilled Employees }\end{array}$ & No. & $\mathbf{( \% )}$ & No. & $\mathbf{( \% )}$ & No. & $\mathbf{( \% )}$ & No. & (\%) & No. & (\%) & No. & (\%) \\
\hline Skilled & 7310 & 62.1 & 3409 & 54.6 & 5784 & 74.6 & 1458 & 46.6 & 1431 & 70.8 & 19392 & 62.7 \\
\hline Unskilled & 4463 & 37.9 & 2836 & 45.4 & 1972 & 25.4 & 1674 & 53.4 & 589 & 29.2 & 11534 & 37.3 \\
\hline Total & $\mathbf{1 1 7 7 3}$ & $\mathbf{1 0 0}$ & $\mathbf{6 2 4 5}$ & $\mathbf{1 0 0}$ & $\mathbf{7 7 5 6}$ & $\mathbf{1 0 0}$ & $\mathbf{3 1 3 2}$ & $\mathbf{1 0 0}$ & $\mathbf{2 0 2 0}$ & $\mathbf{1 0 0}$ & $\mathbf{3 0 9 2 6}$ & $\mathbf{1 0 0}$ \\
\hline
\end{tabular}

Source: Field Research

\subsection{Wage Cost}

Table 5.22 shows the wage structure for skilled and unskilled employees in the QIZs. Wages in the zone are regulated by the government, companies in the QIZs must pay at least the minimum wages to the employees. Minimum wage is determined by the government with around US\$ 130 in a month. Wage structure in the zones differs between local employees and foreign employees. For example, the questionnaire results shows that companies differentiate between skills and unskilled employees, where unskilled employees are paid the minimum wage and skilled employees are paid more than the minimum wage. Companies were willing to pay around US\$ 150 on average for unskilled employees per month including overtime, while for skilled employees they pay around US\$ 226 on average. It is worth mentioning here that companies considered local employees to be unskilled and foreign employees to be skilled. According to the result of the field 
research, only 5 percent of local employees were considered skilled in all QIZ companies. Despite the perception that local employees are unskilled, investors show a greater willingness to hire them than foreigners, as they are two to three times cheaper than their foreign counterparts. This is because investors have to provide foreign workers with air tickets, accommodation, food, work fees, and transportation. Nonetheless and contrary to the expectation, the study finds that investors prefer to hire foreigners than locals although they are much expensive for them than locals. The investors consider foreign workers to be more productive than their local counterparts. Nevertheless, foreign employees are paid more than locals and investors still hire more foreign employees.

\section{Table 5.22: Wage Structure for Skilled and Unskilled Employees}

\begin{tabular}{|c|c|c|c|}
\hline \multirow{2}{*}{$\begin{array}{c}\text { Minimum } \\
\text { Wage }\end{array}$} & \multicolumn{2}{|c|}{$\begin{array}{c}\text { Average Wage in } \\
\text { US\$ for }\end{array}$} & \multirow{2}{*}{ Differences } \\
\cline { 2 - 3 } & Unskilled & Skilled & \\
\hline 130 & 150 & 226 & 76 \\
\hline
\end{tabular}

Source: Field Research

\subsubsection{Work Conditions in the QIZs}

Work conditions in the QIZs is beyond the scope of this study, owing to difficulty of receiving permission from the companies to interview the employees during work time, the limit of time to finish the primary aims of this study and the need to fill out the questionnaire on time.

Nevertheless, based on the visits to the zones during the field research, it was noted that both local and foreign employees face the same working conditions in the QIZs. The interviewer has observed some conditions that workers face during working time. For instance, for local workers, the work time is 8 hours in addition to 3 hours at least overtime on average, while for foreign workers it is 10 hours in addition to 4 hours overtime (see table 5.23). In some companies, it was noted that there are no place for the workers to eat on company premises, with most of the workers were sitting and eating on the edge of the premises. Also in some workplace, there was no air-conditioning and the temperature was very high. Other problems faced by workers, such as availability of clean water, bathrooms conditions, bad treatment, vacations, and health care were documented in a report issued by the United Students Against Sweatshops in 2004. The results of that report were based on interviews with the workers in the QIZs and indicated that both foreign and local workers 
faced bad working conditions in the QIZ companies. Moreover, foreign workers have more problems than locals. Locals have to leave the companies after work to meet their family obligations, while foreigners have to work for long hours and sometime into the middle of the night.

Table 5.23: Working Time

\begin{tabular}{|l|c|c|c|c|c|c|}
\hline & $\begin{array}{c}\text { Al } \\
\text { Tajamouat } \\
\text { Industrial } \\
\text { City }\end{array}$ & $\begin{array}{c}\text { Al Hassan } \\
\text { Industrial } \\
\text { Estate }\end{array}$ & $\begin{array}{c}\text { Al Dulayl } \\
\text { Industrial } \\
\text { Park }\end{array}$ & $\begin{array}{c}\text { Al } \\
\text { Hussein } \\
\text { Bin } \\
\text { Abdullah } \\
\text { II (Karak) }\end{array}$ & $\begin{array}{c}\text { Cyber City } \\
\text { Park }\end{array}$ & Total \\
\hline Working Time & No. & No. & No. & No. & No. & No. \\
\hline Daily & 8 & 8 & 8 & 8 & 8 & 40 \\
\hline Average Overtime & 3 & 3 & 2 & 6 & 4 & 3.6 \\
\hline
\end{tabular}

Source: Field Research

\subsubsection{Vocational Training}

Generally, QIZs companies started training local employees before and after take off. As for foreign employees, they have the knowledge and experience before coming to the country and they are excluded from training. Table 5.24 highlights the importance of vocational training offered to local employees by QIZs companies. It indicates that around two thirds (63.2 percent) of the sample companies stop offering vocational training for the new entrants, while only one third provide local employees with training. In fact, the respondents indicated that they have started to offer training for local employees in the early years of establishment, and after that they cease further training. This is because of the instability of local employees, as many respondents agreed that it is not profitable to them to spend time training local employees who will either quit their jobs or move to another company. In general, the vocational training offered to local employees in the QIZs is very weak and not providing local employees with the knowledge, they require to develop or to be retained by the companies. In order to cover this shortage in training, the government launched a new vocational training program aiming to provide new entrants to the labor market with basic knowledge to be capable to work. Precisely, training is targeting the new entrants and unqualified local employees in rural area, where unemployment is high and then, to provide them with a job in the QIZs companies. In general, as has been reported by AMIR program, the vocational training offered by the government has some shortfalls, for example, the training offered to the local employees is not adapted to the need of production lines in the QIZs companies ${ }^{58}$.

\footnotetext{
${ }^{58}$ AMIR Program, (2001). Review of the Effectiveness and impact of Jordanian Investment Incentives, QIZ Labor Study.
} 
Table 5.24: Vocational Training

\begin{tabular}{|c|c|c|c|c|c|c|c|c|c|c|c|c|}
\hline \multirow[b]{2}{*}{ Vocational Training } & \multicolumn{2}{|c|}{$\begin{array}{l}\text { Al Tajamouat } \\
\text { Industrial City }\end{array}$} & \multicolumn{2}{|c|}{$\begin{array}{c}\text { Al Hassan } \\
\text { Industrial } \\
\text { Estate }\end{array}$} & \multicolumn{2}{|c|}{$\begin{array}{c}\text { Al Dulayl } \\
\text { Industrial } \\
\text { Park }\end{array}$} & \multicolumn{2}{|c|}{$\begin{array}{l}\text { Al Hussein } \\
\text { Bin Abdullah } \\
\text { II (Karak) }\end{array}$} & \multicolumn{2}{|c|}{$\begin{array}{l}\text { Cyber City } \\
\text { Park }\end{array}$} & \multicolumn{2}{|c|}{ Total } \\
\hline & No. & $(\%)$ & No. & $(\%)$ & No. & $(\%)$ & No. & $(\%)$ & No. & $(\%)$ & No. & $(\%)$ \\
\hline Yes & 3 & 18.8 & 6 & 66.7 & 2 & 22.2 & 2 & 100.0 & 1 & 50.0 & 14 & 36.8 \\
\hline No & 13 & 81.3 & 3 & 33.3 & 7 & 77.8 & 0 & 0.0 & 1 & 50.0 & 24 & 63.2 \\
\hline Total & 16 & 100 & 9 & 100 & 9 & 100 & 2 & 100 & 2 & 100 & 38 & 100 \\
\hline
\end{tabular}

Source: Field Research

\subsubsection{The Role of QIZs in Reducing Unemployment Rate}

Despite the high increase of the number of foreign as opposed to local, QIZs contribute positively to reduce the unemployment rate in a minor way and create jobs for local workers. Although there has been an increase in the unemployment rate in some years, the number of jobs that have been created by QIZs companies is remarkable. Table 5.25 shows the contribution of QIZs in reducing the unemployment rate in the country.

The unemployment rate is still persistently high, but decreasing at the same time due to the government reform policy undertaken during the last decade. The contribution of QIZs to the reduction in the unemployment rate shows a slight impact on the unemployment segment. For instance, in the year 2000 QIZs contribute with around 0,04 percentage point in the decrease of unemployment rate, while in 2004 it contributed around 0,11 percentage points. The increase of the relative importance of these zones in creating jobs for locals is remarkable, although local employees consist of around 40 percent of the total employment in these zones, it's impact with regard to creating jobs for local employees in rural areas is notable (see table 5.19). The companies in the QIZs were able to retain a greater number of jobs, which perhaps shows the greater ability of these zones to help in solving the unemployment problem in the country.

In our view, if more attention is given from the responsible parties to local employees in the QIZs, with regard to substituting foreign workers gradually, a considerable decrease in unemployment rate will appear and take place in the medium-term. Of course this point of view is known by policy-makers, but without doing anything to the current situation this will result in the deterioration the efforts of many years of hard work in order to attract investors and creating jobs to local employees. 
Table 5.25: Contribution of QIZs in Reducing Unemployment Rate

\begin{tabular}{|l|c|c|c|c|c|}
\hline \multicolumn{1}{|c|}{$\%$} & $\mathbf{2 0 0 0}$ & $\mathbf{2 0 0 1}$ & $\mathbf{2 0 0 2}$ & $\mathbf{2 0 0 3}$ & $\mathbf{2 0 0 4}$ \\
\hline Contribution of Workers in Labor Force & 0,3 & 0,6 & 0,7 & 0,9 & 0,9 \\
\hline Unemployment Rate & 13,7 & 14,7 & 15,3 & 14,5 & 12,5 \\
\hline $\begin{array}{l}\text { Contribution of QIZs in Reducing } \\
\text { Unemployment Rate }\end{array}$ & 0,04 & 0,08 & 0,11 & 0,13 & 0,11 \\
\hline
\end{tabular}

Source: Author calculation based on the field research

\subsubsection{The Effects of QIZs on the Balance of Payment}

The effect of QIZs on the balance of payment (BOP) can be observed through two main channels. The first channel is through the mechanism of trade balance, while the second one is through the current transfer (see table 5.26).

\subsubsection{Trade Balance}

The trade balance represent the difference between the value of the goods and services that a country exports and the value of the goods and services that it imports. The Jordanian trade balance witnessed a severe deficit in all time periods. Generally, Jordan suffers from a chronic deficit in its trade balance resulting mainly from its modest resources and production bases and high consumption patterns. Imports have historically been two to three times higher than domestic exports. Between 2000 and 2004 imports increased from 23.6 percent to 41.5 percent. On the other hand trade deficit registered an average growth of around 20.5 percent over the period from 2000 to 2004, which indicates the dependency of Jordan economy upon the world.

The effects of QIZs on the trade balance can be shown via, exports of manufacturing goods and imports of raw material and intermediate goods. In the exports side of trade balance, there was a remarkable increase in exports over the last years, this increase was supported mainly by the export-oriented policies and the structural reforms adopted during the 90s by the government. In particular, exports benefited from the QIZ agreement with the USA and Israel, owing to the high demand for the Jordanian exports from the USA market which increase dramatically from US\$ 25.1 million to US\$ 1121.2 million during the period 2000 to 2004 respectively. This increase in exports was attributed mainly to the good performance of QIZs. In general, the good performance of exports should be reflected on the BOP. The BOP can be improved either through decreasing the deficit of the trade 
balance or even increasing the surplus of it. Usually, increasing exports means increasing earning of foreign currencies.

Nonetheless, the remarkable increase in exports during the period 2000-2004 in particular, was due to the good performance of QIZs. Even so, the high increase in exports is not adequate to cover the high increase in imports. This is because imports witnessed a higher increase than exports during the same period and as a result severe trade deficit appeared throughout the studied period.

Although the high increase in the trade deficit over long period of time can consume all the proceeds that the country gains from exports of QIZs, works remittance, tourist and foreign aids, the trade deficit can not harm the economy while the balance of payments is in balance or even in surplus. In addition to the effect of QIZs on the trade balance, It is worth mentioning that there were interrelated factors participate in increasing the trade deficit such as a) the increase of imported oil prices, b) the effects of the exchange rate on imports from Europe and Japan, and c) the flow of thousands of Iraqi families to Jordan, which increased the local demand for goods on the economy. In general, ignoring the negative effects of imports and talk only about the benefits of exports is engaging in false accounting. Below is a brief summary of the performance of the main components of the trade balance during the period 2000 - 2004.

\subsection{Domestic Exports}

Domestic exports recorded strong growth during the period 2000 - 2004, with an average annual growth rate of 18.2 percent. The remarkable growth of exports was due to different factors such as (1) the role of the private sector in boosting exports by penetrating new markets. (2) The improved competitiveness of Jordanian products abroad. (3) The exportled growth strategy and free market policy to liberalize the economy which was adapted in the late of 1980s. (4) The exchange-rate regime, which was followed post the mid of 1990s. One of government tools is to adopt export led growth; throughout this strategy, export performance continues to drive the economy forward. Recent available data shows that domestic export increased in 2004 by 42.4 percent reaching US\$ 3.3 billion compared to a growth of 2.7 percent and a value of US\$ 1.5 billion in 2000. Besides the above reasons that boost the performance of domestic exports, the QIZs play a big role in this good 
performance. Latest data shows that export from QIZs increased in value from US\$ 25.4 Million in 2000 to US\$ 1121.2 Million in 2004 and compose around 34.1 percent of the domestic exports (see table 5.26).

\subsection{Imports}

Jordan's imports steadily increased at an average annual rate of 17.7 percent during the period 2000 - 2004, this increase was due largely to the increase in world prices of imported oil and the exchange regime followed by the central bank from the mid of 1990s, in addition to the reduction of imports tariff. Latest data shows that imports value stood at US\$ 8.1 billion in the year 2004 compared to 4.6 billion in the year 2000. Such a high increase in imports mainly resulted from the increase in imported oil prices, rising imports of machinery and transport equipment following the reduction of custom duties on imports of raw materials and intermediate goods which supported the robust economic growth during the last years.

Imports made by QIZs also help to increase total value of imports either by importing raw materials or capital goods. Recent data shows that imports of raw materials and intermediate goods (excluding capital goods) used for textiles industries in the QIZs consists of around 8.6 percent of total imports in 2004, compared with about 4.3 percent imports in the year 2000.

The data in table 5.26 highlights the fact that QIZs participate both in increasing imports and exports at the same time. This implies that as exports increase, imports will also have to increase. However, if the increase in exports exceeds the increase in imports, this will be more beneficial to the country than when imports exceed exports. In 2004 imports from QIZs contribute around 3.5 percentage points in the growth of total imports comparing to 0.7 percentage points in 2000, while exports make up about 14.5 percentage points to the growth of domestic exports. Overall, QIZs contribute positively to reducing the trade deficit, despite the increase of imports. 
Table 5.26: Trade Performance 2000 - 2004

\begin{tabular}{|c|c|c|c|c|c|}
\hline & & & & & Million US\$ \\
\hline & 2000 & 2001 & 2002 & 2003 & 2004 \\
\hline Imports & 4598.9 & 4878.5 & 5083.3 & 5751.4 & 8137.0 \\
\hline Change \% & 23.6 & 6.1 & 4.2 & 13.1 & 41.5 \\
\hline $\begin{array}{l}\text { Domestic } \\
\text { exports }\end{array}$ & 1520.0 & 1910.0 & 2190.0 & 2310.0 & 3290.0 \\
\hline Change \% & 2.7 & 25.7 & 14.7 & 5.5 & 42.4 \\
\hline Trade Balance & -3078.9 & -2968.5 & -2893.3 & -3441.4 & -4847.0 \\
\hline Change \% & 37.3 & -3.6 & -2.5 & 18.9 & 40.8 \\
\hline \multicolumn{6}{|c|}{ Trade Performance of QIZs 2000 - 2004} \\
\hline Imports $^{59}$ & 137.2 & 260.7 & 380.3 & 449.0 & 696.3 \\
\hline Change \% & -11.4 & 90.0 & 45.9 & 18.1 & 55.1 \\
\hline Exports & 25.1 & 150.3 & 381.7 & 574.0 & 1121.2 \\
\hline Change \% & 945.8 & 498.8 & 154.0 & 50.4 & 95.3 \\
\hline Trade Balance & -112.1 & -110.4 & 1.4 & 125 & 424.9 \\
\hline $\begin{array}{l}\text { Net Foreign } \\
\text { Exchange } \\
\text { Earning }\end{array}$ & -446.6 & -73.5 & 0.4 & 21.8 & 37.9 \\
\hline \multicolumn{6}{|c|}{ Share of QIZs in Domestic Exports and Imports (\%) } \\
\hline Imports & 3.0 & 5.3 & 7.5 & 7.8 & 8.6 \\
\hline Exports & 1.7 & 7.9 & 17.4 & 24.8 & 34.1 \\
\hline \multicolumn{6}{|c|}{ Contribution of QIZs in Exports and Imports Growth (\%) } \\
\hline Imports & 0.7 & 0.3 & 0.3 & 1.0 & 3.5 \\
\hline Exports & 0.04 & 2.0 & 2.6 & 1.4 & 14.5 \\
\hline
\end{tabular}

Sources: Central Bank of Jordan, annual report 2004, and author calculation

\subsection{The Potential Foreign Currency Earning}

In terms of trade balance, the trade balance can have either one of two impacts on the potential foreign exchange earnings or losses for the country. For example, if the imports of the country exceed the exports, these may use up the valuable foreign exchange reserves in order to finance imports in this case it considered as capital outflow. On the other hand, if the country exports were more than imports, it may gain valuable foreign exchange earnings from this trade, and in this case it is recorded as capital inflow into the country.

With regard to QIZs, it has been assumed that QIZs play a significant role in increasing exports and accelerating the earning of foreign exchange. However, what officials have ignored is the figures for both exports and imports. This is because exports alone cannot be considered as an indicator to the value of foreign earning to the country, because there is a high increase in imports at the same time. This could consume all the profits obtained from exports, unless there are other sources than exports which might be used to cover the

\footnotetext{
${ }^{59}$ Imports of QIZs were estimated by subtracting total imports of textile for the whole economy before establishing QIZs from imports of textile after establishing QIZs.
} 
shortage of exports, such as foreign aid. The potential earning of foreign exchange should help to reduce the trade deficit. In order to be able to assess the foreign exchange earning of QIZs we have to look at the Net Foreign Exchange Earning as a percentage of export (NFEE) according to the following formula:

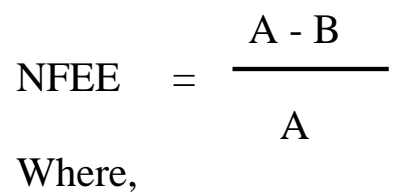

NFEE is Net Foreign Exchange Earning as a percentage of exports,

A is the FOB value of exports by the QIZs; and

B is the total of the CIF value of all imported inputs.

According to the results in table 5.26, NFEE was negative in the years 2000 and 2001, while in the following years NFEE starts to witness a slight increase and reports a positive amount of around US\$ 37.9 million in the year 2004. In this context we can say that QIZs play a role in increasing the potential exchange earning to the country, but still this increase is not as remarkable and significant as expected.

\subsubsection{Current Transfer}

The other effect that QIZs are assumed to have on the balance of payment is through the current transfer. The current transfer includes Worker's Remittances, in the payments side it represents outward transfers made by non-Jordanians residing and working in Jordan. These remittances are estimated on the basis of data obtained from the field research on foreign workers and the average monthly transfer per worker. Foreign employees within the QIZs each earn around US\$ 226 on average per month. It has been assumed that every worker spent around 20 percent of his income in buying goods and services from the local market, and this contributes to the tax revenues and increases the value added to the economy by their spending around 20 percent of wages inside the local economy. This is because foreign workers in the QIZs were provided with accommodation, food, transportation, and air tickets. In addition, the behavior of any foreign employees in the world stems from the fact that they are working to save money and transfer it to their home countries. The remaining 80 percent is assumed to be transferred out of the country. 
According to the table 5.27, QIZs contribute 25.7 percent of the outflows of worker's remittances in the year 2004, comparing with 5.8 percent in the year 2000.

Table 5.27: Contribution of QIZs in Current Transfer

\begin{tabular}{|c|c|c|c|c|c|c|c|}
\hline & $\begin{array}{c}\text { No. of } \\
\text { Foreign } \\
\text { Employees }\end{array}$ & $\begin{array}{c}\text { Average } \\
\text { Income per } \\
\text { Foreign } \\
\text { Worker }\end{array}$ & $\begin{array}{c}\text { Consumption } \\
\text { by Foreign } \\
\text { Employee }\end{array}$ & $\begin{array}{c}\text { Income of } \\
\text { Skilled } \\
\text { Workers }\end{array}$ & $\begin{array}{c}\text { Net } \\
\text { Income } \\
\text { Transfer }\end{array}$ & $\begin{array}{c}\text { Workers } \\
\text { Remittances }\end{array}$ & $\begin{array}{c}\text { Contribution } \\
\text { of QIZs in } \\
\text { Outflows }\end{array}$ \\
\hline $\mathbf{2 0 0 0}$ & 3334 & 2712 & $20 \%$ & 9.1 & 7.2 & 123.6 & 5.8 \\
\hline $\mathbf{2 0 0 1}$ & 5754 & 2712 & $20 \%$ & 15.6 & 12.5 & 120.8 & 10.3 \\
\hline $\mathbf{2 0 0 2}$ & 8426 & 2712 & $20 \%$ & 22.9 & 18.3 & 121.3 & 15.1 \\
\hline $\mathbf{2 0 0 3}$ & 13195 & 2712 & $20 \%$ & 35.8 & 28.6 & 141.9 & 20.2 \\
\hline $\mathbf{2 0 0 4}$ & 18785 & 2712 & $20 \%$ & 50.9 & 40.8 & 170.1 & 24.0 \\
\hline $\mathbf{2 0 0 5}$ & 21298 & 2712 & $20 \%$ & 57.8 & 46.2 & 179.7 & 25.7 \\
\hline
\end{tabular}

Sources: Central Bank of Jordan Monthly Bulletin November 2005, and author calculation

\subsubsection{Backward and Forward Linkages}

Backward and forward linkages were considered to be one of the main reasons for Jordan to establish the QIZs, through increasing the output from the zone and raising the standard of local companies that supply goods and services to the zone. In the case of QIZs, the field study shows that there are no forward linkages appearing to be significant, because the principle of these zones is to produce products only for export. Backward linkages seem to be more significant than forward linkages. This is because intermediate and raw materials are assumed to be supplied from the local companies inside the country. In other words establishing QIZs can be useful for other sectors in the economy through covering the needed services and inputs from the local economy. In contrary to the expectation, most of the companies in the QIZs have limited effects in creating backward linkages to the local economy. The limitation of zones in creating backward linkages can be related to the following reasons: 1) the high degree of imported contents in QIZs goods is an indication that backward linkages with local economy remain quite insignificant, 2) most of the companies are connected with offshore companies where the latter supply most of the intermediate and raw materials to the companies in the QIZs, and 3) the unavailability of the raw materials and intermediate goods in the local economy. Therefore, linkages between QIZs companies and local producers are mostly limited to the provision of packaging materials and simple inputs. It is therefore hardly surprising that few backward linkages have developed between QIZ companies and local companies. In general, almost all QIZ companies imported their machines, raw materials and input materials from outside, usually from Asian countries, Israel, and the USA. Table 5.28 shows that around 
57.9 percent of the sample companies cooperate with local companies outside the zone. With the rest of the sample companies, 42.1 percent show that there is no cooperation with local companies. This result indicates that linkages with the local economy are limited and only consisted of a few light things such as supplying QIZ companies with cartons, nylons, and transportation. In addition, QIZs companies make use of banks, and local transport using facilities including the port of Aqaba. However, the overall effects are limited and have not been as expected from the QIZs.

Table 5.28: Cooperation Between QIZs and Local Companies

\begin{tabular}{|c|c|c|c|c|c|c|c|c|c|c|c|c|}
\hline \multirow[b]{2}{*}{$\begin{array}{l}\text { Cooperation With Local } \\
\text { Companies }\end{array}$} & \multicolumn{2}{|c|}{$\begin{array}{c}\text { Al } \\
\text { Tajamouat } \\
\text { Industrial } \\
\text { City } \\
\end{array}$} & \multicolumn{2}{|c|}{$\begin{array}{c}\text { Al } \\
\text { Hassan } \\
\text { Industria } \\
\text { l Estate }\end{array}$} & \multicolumn{2}{|c|}{$\begin{array}{l}\text { Al Dulayl } \\
\text { Industria } \\
\text { I Park }\end{array}$} & \multicolumn{2}{|c|}{$\begin{array}{l}\text { Al Hussein } \\
\text { Bin } \\
\text { Abdullah II } \\
\text { (Karak) }\end{array}$} & \multicolumn{2}{|c|}{$\begin{array}{l}\text { Cyber } \\
\text { City Park }\end{array}$} & \multicolumn{2}{|c|}{ Total } \\
\hline & No. & $(\%)$ & No. & $(\%)$ & No. & $(\%)$ & No. & (\%) & No. & (\%) & No. & $(\%)$ \\
\hline Yes & 6 & 37.5 & 7 & 78 & 6 & 67 & 1 & 50 & 2 & 100 & 22 & 57.9 \\
\hline No & 10 & 62.5 & 2 & 22 & 3 & 33 & 1 & 50 & 0 & 0 & 16 & 42.1 \\
\hline Total & 16 & 100 & 9 & 100 & 9 & 100 & 2 & 100 & 2 & 100 & 38 & 100 \\
\hline
\end{tabular}

Source: Field Research

\subsubsection{The Multiplier Impacts}

The economic impact of QIZs deal with aspects related to the potential benefit and cost on the whole economy as a result of establishing these zones. In order to understand the potential benefit that QIZs generate, we will try to apply the concept of the multiplier to help predict the ripple effects of these zones on the local economy. QIZs are considered new phenomena in the country and are assumed to have economic impacts beyond employment, income generated, economic growth, technology transfer, and backward linkage. Hence, the multiplier can summarize the whole effects of establishing these zones on the entire economy.

The multiplier summarizes the total impact that can be expected from the change in any given activity in the economy. For instance, an increase in exports resulted from new manufacturing industry can spur ripple effects or spin-off activities. Thus, the multiplier can measure the impact of export, including the result of the ripple effects, thus policy makers can assess if it is costly or beneficial to the country.

For example, direct effects occurred when the companies start operation and exporting goods. Indirect effects occurred when local companies support exporting companies, while 
induced effects resulted from foreign workers spending in the local economy. To illustrate the use of multiplier, we should look at the multiplier effects resulting from the companies in QIZs produced to export to USA market. In this case, for every US\$ 1 exported to the USA market, around US\$ 0.22 on average of the production cost was spent by the companies locally. In other words, every US\$ 1 value produced and exported generated 1.22 US\$ output for the local economy. In general, the higher the multiplier the greater the effects of QIZs on the local economy. Table 5.29 demonstrates the direct, indirect, induced effects and the multiplier effects for companies working in the QIZs during the period 2000 to 2004.

Table 5.29: Average Direct, indirect, and induced effects of QIZ companies 2000 - 2004

\begin{tabular}{|c|c|c|c|c|}
\hline US\$ & $\begin{array}{c}\text { Average } \\
\text { direct effects }\end{array}$ & $\begin{array}{c}\text { Average } \\
\text { indirect } \\
\text { effects }\end{array}$ & $\begin{array}{c}\text { Average } \\
\text { induced } \\
\text { effects }\end{array}$ & Multiplier \\
\hline $\mathbf{2 0 0 0}$ & 6742420 & 256343 & 980160 & 1.33 \\
\hline $\mathbf{2 0 0 1}$ & 28483910 & 718120 & 1575024 & 1.14 \\
\hline $\mathbf{2 0 0 2}$ & 31580615 & 964974 & 2725969 & 1.20 \\
\hline $\mathbf{2 0 0 3}$ & 37547733 & 1201230 & 3573993 & 1.22 \\
\hline $\mathbf{2 0 0 4}$ & 38635097 & 1248585 & 3876400 & 1.23 \\
\hline Average & $\mathbf{3 2 5 5 7 5 5}$ & $\mathbf{7 3 8 6 3 0}$ & $\mathbf{2 2 2 5 9 2 4}$ & $\mathbf{1 . 2 2}$ \\
\hline
\end{tabular}

Source: Author calculation based on data obtained from MOP

Table 5.29 presents the average multiplier between the years 2000 to 2004. It shows the fluctuation of the multiplier during the studied period. The table shows that the multiplier registered a sharp decrease of about 14.5 percent in 2001, while in the years 2002 and 2003 it start to register a slight increase of around 5.9 percent and 1.6 percent respectively. Then it increased slightly by around 0.8 percent in 2004 and stood at 1.23 . Overall, the multiplier stood at 1.22 on average between the years 2000 - 2004. The fluctuations that the multiplier witnessed might have resulted from the following: a) the closure of many companies, b) the establishment of new companies, and c) the increase of direct costs due to the expansion of the production process by the companies and the change in government regulations and laws. In general, the low result of the multiplier is expected from these kinds of zones. According to the World Bank Group ${ }^{63}$, the multiplier impact of QIZs on the local economy

\footnotetext{
${ }^{60}$ Average direct effects obtained from MOP for the year 2001, and then adjusted to other years by weighted average, consumer price index and number of companies.

${ }^{61}$ Average indirect effects obtained from MOP for the year 2001, and then adjusted to other years by weighted average, consumer price index and number of companies.

${ }^{62}$ Average induced effects assumed to represent 20 percent of foreign workers wages.

${ }^{63}$ World Bank Group, (2003). Quarterly publication about Jordan.
} 
is limited. This is because the majority of employees were foreign, in addition to the importing of a large share of intermediate goods.

\subsubsection{Productivity and cost of labor in the QIZs}

Productivity is defined as the ratio of output to the input (OECD, 2001) ${ }^{64}$. In practice productivity can be measured by dividing the total output into the total input. Following the manual of OECD for measuring productivity and using the available data from the field research and other sources such as Central Bank of Jordan and Ministry of Industry and Trade (MIT), we can calculate the average productivity per workers and cost of labor. The method which has been followed is as follows: labor productivity for the whole economy has been derived from the real Gross Domestic Product (GDP), while the part for input is computed on the basis of the labor force. Productivity in the manufacturing sector has been derived from the sectoral components of GDP, while labor force in this sector has been adjusted according to its contribution to the total labor force of the country.

For labor productivity in QIZs, data in production (exports) has been obtained from MIT, while data for employment (local and foreign) were obtained from the field research. All data have been adjusted according to real terms. Owing to data limitations, employee working hours are treated as homogenous and additive, with no distinction made between the hours of different groups of employees.

To calculate the labor productivity index, we consider the base year to be the year 2002. In general, the calculation of productivity is aimed to measure the trend in labor productivity in the QIZs over the last 5 years. Productivity measures are based on the following formula:

$$
\begin{gathered}
\text { Productivity }=\frac{\text { Total Output }}{\text { Total input }} \\
\text { Labor Productivity }=\frac{\text { Output }}{\text { No. of hours input }} \\
\text { Labor Productivity Index }=\frac{\text { Output } t 1}{\text { Output } t 0} \% \frac{\text { No. of hours input } t 1}{\text { No. of hours input } t 0}
\end{gathered}
$$

\footnotetext{
${ }^{64}$ OECD Manual, (2001). Measuring Productivity, Measurement of Aggregate and Industry-level Productivity Growth.
} 
where $t_{1}$ represents the current year and to the base year.

Table 5.30 highlights the trends in labor productivity between the years 2000 - 2004. It shows that the average labor productivity increased in the QIZs from US\$ 2,166 in the year 2000 to US\$28,595 in the year 2004 and over the same period the average labor cost per hour increased about thirteen times from US\$ 0,7 to US\$ 8,7. However, the increase in labor cost can be mainly attributed to the hiring of foreign employees and to government regulations which increased labor costs via raising working and permit fees for foreign workers.

Moreover, the impact of subcontractor companies is included in calculating labor productivity and, when excluded, the impact of these companies labor productivity will be lower than what has been calculated in table 5.30. Owing to data limitation concerning these companies, it was difficult to exclude them from the calculation. Nonetheless, as productivity of labor increased at a faster pace than labor cost, there will be more investment in the QIZs. Since the increase in productivity is greater than the increase in the labor cost, companies in the QIZs will continue to be profitable for investors. According to Kuang from the University of China, if an enterprise's labor costs increase at a rate faster than workers' productivity, its competitiveness will decrease; otherwise, its competitiveness will increase ${ }^{65}$.

On the other hand, keeping labor costs low to increase competitiveness might not be helpful to the workers in the long run. Though, as low labor costs can be an advantage in QIZs to attract investor and raised exports, economists emphasize that low labor costs can be considered not an entirely positive factor to the economy.

On the contrary, it may contribute to a vicious circle. Workers cannot get the salaries they deserve, so they lose many opportunities to be trained and further educated and this can lead to low productivity and a decrease in international competitiveness.

\footnotetext{
${ }^{65}$ Bian Yi , China Cheap labour cannot last, China Daily 12/08/2005, downloadable from: http://www.chinadaily.com.cn/english
} 
Table 5.30: Labor Productivity and Labor Cost

\begin{tabular}{|c|c|c|c|c|c|}
\hline & \multirow{2}{*}{$\begin{array}{c}\begin{array}{c}\text { Average Labor } \\
\text { Productivity in US\$ }\end{array} \\
\text { Per Employee }\end{array}$} & \multicolumn{2}{|c|}{$\begin{array}{c}\text { Average Labor } \\
\text { Cost in US\$ }\end{array}$} & \multicolumn{2}{|c|}{$\begin{array}{c}\text { Average Labor } \\
\text { Productivity }\end{array}$} \\
\hline & & Per Hour & Per Minute & Index & Percent change \\
\hline \multicolumn{6}{|l|}{2000} \\
\hline All Economy & 9379 & 2.8 & 0.047 & 108.9 & -5.9 \\
\hline Manufacturing Sector & 9342 & 2.8 & 0.047 & 133.9 & -8.1 \\
\hline QIZs & 2166 & 0.7 & 0.011 & 15.7 & 482.6 \\
\hline \multicolumn{6}{|l|}{2001} \\
\hline All Economy & 8719 & 2.6 & 0.044 & 101.3 & -7.0 \\
\hline Manufacturing Sector & 7349 & 2.2 & 0.037 & 105.3 & -21.3 \\
\hline QIZs & 8466 & 2.6 & 0.043 & 61.4 & 290.8 \\
\hline \multicolumn{6}{|l|}{2002} \\
\hline All Economy & 8610 & 2.6 & 0.043 & 100.0 & -1.2 \\
\hline Manufacturing Sector & 6977 & 2.1 & 0.035 & 100.0 & -5.1 \\
\hline QIZs & 13790 & 4.2 & 0.070 & 100.0 & 62.9 \\
\hline \multicolumn{6}{|l|}{2003} \\
\hline All Economy & 8588 & 2.6 & 0.043 & 99.7 & -0.3 \\
\hline Manufacturing Sector & 7830 & 2.4 & 0.040 & 112.2 & 12.2 \\
\hline QIZs & 17596 & 5.3 & 0.089 & 127.6 & 27.6 \\
\hline \multicolumn{6}{|l|}{2004} \\
\hline All Economy & 9878 & 3.0 & 0.050 & 114.7 & 15.0 \\
\hline Manufacturing Sector & 8073 & 2.4 & 0.041 & 115.7 & 3.1 \\
\hline QIZs & 28595 & 8.7 & 0.144 & 207.4 & 62.5 \\
\hline
\end{tabular}

Source: Author calculation based on the field research data.

Note: the base year was assumed to be the year 2002, also it was assumed that annual working days are 300 days, and the average working hour with overtime is 11 hours for both local and foreign employees.

\subsubsection{Contribution of QIZs in Economic Growth}

It has been assumed that the QIZs contribute in the high economic growth which has been attained during the last years. The mechanism of transferring the effects of QIZs into economic growth appears through two simultaneous channels: the amount of exports produced within the QIZs and the use of foreign currency earning from QIZs exports to cover the imports of capital goods. In general Jordan's economic growth attained during the last years is usually described as export-driven, mainly from the QIZs. According to the World Bank Group, the economic growth attained during the year 2002 was mainly driven by textile exports, especially from QIZs ${ }^{66}$. Also, the former minister of the Ministry of Planning, Smadi, announced that the high economic growth achieved in 2004 was related to the external high demand for the Jordanian products from outside and was due to the international trade agreements between Jordan and other countries from the other side ${ }^{67}$.

On one hand, QIZs help to increase growth through the manufactured export which leads to an increase in the foreign currency earning. On the other hand, increasing foreign currency

\footnotetext{
66 The World Bank Group, (2003). First Quarter, A Quarterly Publication of the Jordan Country Unit.

${ }^{67}$ Alrai Daily Newspaper, Economic growth reached 7.5 percent march 2005.
} 
earning allows rising imports of capital and consumer goods which might in the end foster the economic growth. In order to be able to assess the role of QIZs export on the economic growth we will analyze the causality of economic growth in Jordan.

The relationship between export and economic growth can be described by the contributions of exports through analysis of the 'demand side' of the economy. This demand-side approach is also called 'demand oriented analyses. According to the traditional Keynesian theory, the increase of exports is considered to be one of the factors that can stimulate increases in demand and will surely lead to increases in outputs. The contribution of exports in economic growth can be described according to the following identity:

$\mathrm{Y}=\mathrm{C}+\mathrm{I}+\mathrm{G}+(\mathrm{X}-\mathrm{M})$

Where $\mathrm{Y}$ is national income, I is investment, $\mathrm{C}$ is private consumption, $\mathrm{G}$ is government consumption, and $\mathrm{X}, \mathrm{M}$ are export and import respectively. By differentiating equation (1) with respect to time we can see that:

$\mathrm{dy} / \mathrm{dt}=\mathrm{dc} / \mathrm{dt}+\mathrm{di} / \mathrm{dt}+\mathrm{dg} / \mathrm{dt}+\mathrm{d}(\mathrm{x}-\mathrm{m}) / \mathrm{dt}$

equation (2) can be written in the following terms:

$\frac{\mathrm{dy} / \mathrm{dt}}{\mathrm{y}}=\frac{\mathrm{dc} / \mathrm{dt}}{\mathrm{c}} \frac{\underline{\mathrm{c}}}{\mathrm{y}}+\frac{\mathrm{di} / \mathrm{dt}}{\mathrm{i}} \frac{\mathrm{i}}{\mathrm{y}}+\frac{\mathrm{dg} / \mathrm{dt}}{\mathrm{g}} \underset{\mathrm{y}}{\mathrm{g}}+\frac{\mathrm{d}(\mathrm{x}-\mathrm{m}) / \mathrm{dt}}{(\mathrm{x}-\mathrm{m})} \frac{(\mathrm{x}-\mathrm{m})}{\mathrm{y}}$

where $\frac{\mathrm{dy} / \mathrm{dt}}{\mathrm{y}}=\frac{\mathrm{dc} / \mathrm{dt}}{\mathrm{c}}+\frac{\mathrm{di} / \mathrm{dt}}{\mathrm{i}}+\frac{\mathrm{dg} / \mathrm{dt}}{\mathrm{g}}+\frac{\mathrm{d}(\mathrm{x}-\mathrm{m}) / \mathrm{dt}}{(\mathrm{x}-\mathrm{m})}$, signify the growth rate of the variables and $\frac{\mathrm{c}}{\mathrm{y}}, \frac{\mathrm{i}}{\mathrm{y}}, \mathrm{g}, \frac{(\mathrm{x}-\mathrm{m})}{\mathrm{y}}$,

Signify respectively the ratio of consumption, investment, government consumption and export less import to the income. When the quantity of any component is changed, its direct impact on the growth rate of income is given by equation 3. Therefore, the direct impact of changes in exports can be estimated accordingly. Table 5.31 presents the contribution rate of these variables on GDP growth rate according to the expenditure approach. The net effects of exports on GDP growth when taking into consideration the impact of imports or the trade balance (Exports minus Imports) is limited, which shows that there are other variables contribute on the GDP growth more than exports. In theory the trade balance should be positively related to GDP. However, the data showed that there is a negative 
relationship in almost all the years. The main reason for this is because an increase in investment and consumption may lead also to an increase in imports and consequently a decrease in net exports but at the same time the GDP as a whole still increases (Zhang \& $\mathrm{Hu}$, 1999). This indicates that there are other variables influencing the GDP growth in addition to export.

Table 5.31: Breakdown of the GDP Growth Rate Components

\begin{tabular}{|c|c|c|c|c|c|c|}
\hline & $\begin{array}{c}\text { Gross } \\
\text { Capital } \\
\text { Formation }\end{array}$ & $\begin{array}{c}\text { Government } \\
\text { Consumption }\end{array}$ & $\begin{array}{c}\text { Private } \\
\text { Consumption }\end{array}$ & $\begin{array}{c}\text { Export of } \\
\text { goods } \\
\text { and } \\
\text { services }\end{array}$ & $\begin{array}{c}\text { Import } \\
\text { of goods } \\
\text { and } \\
\text { services }\end{array}$ & $\begin{array}{c}\text { GDP } \\
\text { Growth } \\
\text { Rate }\end{array}$ \\
\hline 1999 & 0.8 & 0.8 & 2.3 & 1.4 & 1.9 & 3.3 \\
\hline 2000 & 0.9 & 1.0 & 3.3 & 1.9 & 2.7 & 4.5 \\
\hline 2001 & 1.0 & 1.1 & 4.0 & 2.3 & 3.2 & 5.3 \\
\hline 2002 & 1.1 & 1.2 & 4.2 & 2.7 & 3.4 & 5.8 \\
\hline 2003 & 0.8 & 0.9 & 2.9 & 2.0 & 2.3 & 4.3 \\
\hline 2004 & 1.5 & 1.6 & 5.1 & 3.5 & 3.6 & 8.1 \\
\hline
\end{tabular}

Sources: Central Bank of Jordan and author calculation.

Note: the GDP growth rate by expenditure approach differ slightly from the sectoral approach.

As can be seen from table 5.31, the share of exports in the economic growth has been increased during the period 2000 - 2004. The contribution of Jordanian exports to the economic growth and the gross domestic product is much less than this high percentage suggests. This is because only 19.6 percent of the value of exports can be described as value-added and thus may count as a contribution to the gross domestic product of the country. Not bad, but not impressive, according to the economist and journalist Fahed Fanek $^{68}$. No doubt that the increase in exports during the last years contributes positively to the high economic growth of the country, but this contribution is not direct and it is not the case as has been suggested, that the high economic growth obtained during these last years is related to QIZs. In an attempt to clarify this matter, we examined the relationship between exports, imports, and export of manufacturing goods in Jordan over the period from 1980 - 2004. The main results show that the causal relationship between exports and economic growth were unidirectional from economic growth to exports. As exports are considered to be one of the main components of GDP when taking into account the expenditure approach, direct and indirect impacts can be caused by export to economic growth. Undoubtedly, depending heavily on export-led growth strategy to stimulate and accelerate economic growth in Jordan may be misleading. Moreover, this study supports 
the findings of Dodaro 1993, Reizman 1995, and Abu-Qarn and Abu Bader 2001 as opposed to the common belief that export promotion is behind the remarkable growth performance in Jordan. In the next chapter, more detail about the methodology and the econometric techniques that have been used in analysis will be explained.

\subsection{The Fiscal Impacts of QIZs}

This section looks at the fiscal side that QIZs companies assumed to have on the revenue side of the budget. The interviewees were asked to answer and provide information about the potential fiscal impact of QIZs on the economy. Among these questions were those concerning the ranking of the importance of tax exemptions offered to them by the government as a reason to invest in the QIZs, the estimation of the amount of exemptions offered to the investors and the main sources of tax exemptions offered to the investors. The answers to these questions might help improve the scheme for future application.

\subsubsection{Sources of Tax Exemptions}

Table 5.32 lists the main sources of tax exemptions offered to the investors in order to invest in the QIZs. There are three main sources of tax incentives and exemptions offered to investors in Jordan, being: a) Jordan Invest Board (JIB), b) Jordan Industrial Estate Corporation (JIEC), and c) Jordan Free Zone Corporation (JFZC). More details on tax incentives and exemption offered by these semi government organizations are described in table 5.32. This table describes the main sources of tax exemptions offered to the investors within QIZs. It shows that all active QIZs (five zones) benefit from the tax exemptions offered by JIB, while only two zones combined between the tax exemptions offered by JIB and JIEC, and only one zone combined between the tax exemption from JIB and JFZC.

Table 5.32: Sources of Tax Exemptions

\begin{tabular}{|c|c|c|c|c|c|c|}
\hline & $\begin{array}{c}\text { Al } \\
\text { Tajamouat } \\
\text { Industrial } \\
\text { City } \\
\end{array}$ & $\begin{array}{c}\text { Al Hassan } \\
\text { Industrial } \\
\text { Estate }\end{array}$ & $\begin{array}{c}\text { Al Dulayl } \\
\text { Industrial } \\
\text { Park }\end{array}$ & $\begin{array}{l}\text { Al Hussein } \\
\text { Bin Abdullah } \\
\text { II (Karak) }\end{array}$ & $\begin{array}{c}\text { Cyber City } \\
\text { Park }\end{array}$ & Total \\
\hline \multicolumn{7}{|l|}{ Sources of Tax Exemptions } \\
\hline Jordan Investment Board & $\sqrt{ }$ & $\sqrt{ }$ & $\sqrt{ }$ & $\sqrt{ }$ & $\sqrt{ }$ & \\
\hline $\begin{array}{l}\text { Jordan Industrial Estate } \\
\text { Corporation }\end{array}$ & & $\sqrt{ }$ & & $\sqrt{ }$ & & \\
\hline Jordan Free Zone Corporation & & & & & $\sqrt{ }$ & \\
\hline No. of Sources of Tax Exemptions & 1 & 2 & 1 & 2 & 2 & \\
\hline Number of Companies & 16 & 9 & 9 & 2 & 2 & 38 \\
\hline Zone Location & $\mathbf{B}$ & B & $\mathbf{C}$ & $\mathbf{C}$ & B & - \\
\hline
\end{tabular}




\subsubsection{Jordan Investment Board (JIB)}

According to the JIB investment law for the year 1995, and its amendment for the year 2000, investment projects in industry, agriculture, transportation, and other sectors the cabinet decided to add, enjoy two main kinds of tax incentives: 1) an import duty exemption, and 2) an income tax exemption. In the import duties side the main exemptions were in:

$\checkmark \quad$ Exemption of the fixed assists for a period of three years and the possibility to extend this upon approval.

$\checkmark \quad$ Spare parts of fixed assists for the projects are exempted from the import duty from the date of commencement for 10 years.

$\checkmark \quad$ Import of fixed assists resulting from expanding in capacity 25 percent or more are exempted from import duty.

While in income tax side, the country is divided into three development zones: zone A, zone $\mathrm{B}$, and zone $\mathrm{C}$. In zone $\mathrm{A}$ income tax reduction is equal to 25 percent, in zone $\mathrm{B}$ it is equal to 50 percent, and in zone $C$ it is equal to 75 percent for a period of 10 years. In case of an increase of projects capacity by no less than 25 percent, further reduction in income tax for a further four years is offered too. Table 5.32 shows that all companies operating in the QIZs benefit from the tax incentives and exemptions offered by JIB law, but on a different scale and according to the location of QIZs. According to the JIB law, most of QIZs location considered in zone B projects unless these projects fall in zone C.

In this context, we can say freely that, investors' decisions to locate their projects in the QIZs do not concentrate on the generosity of the tax system offered to them. While zone C with 75 percent tax exemption appears to be more attractive than other zones, it has only attracted 11 companies compared with 27 companies investing in zone B. It is also interesting to note that zone $\mathrm{C}$, which is considered the most generous zone in offering tax exemptions to investors and with income tax reduction reduced by 75 percent, is a less attractive zone compared to other zones with higher taxes. This result might reflect the fact that tax incentives and exemptions are not the best and first choice to the government in order to attract investors in the case of QIZs and at the same time, this does not affect investor's decisions to invest in the QIZs (See section 5.5.2). 


\subsubsection{Jordan Industrial Estate Corporation (JIEC)}

Under the JIEC law for the year 1985, any project allocate in the JIEC receive two years of exemption from income and social service tax, in addition to a permanent exemption from property taxes. Moreover, after the end of tax exemption in two years, projects can benefit also from the JIB law for an additional 10 years of tax exemption. Numbers of QIZs under the management of JIEC were found to be only in 2 zones, and home to about 11 companies. In the case of the project located in one of the zones that belongs to JIEC, the project will enjoy more tax exemption. Contrary to investors' behavior, table 5.32 shows that only 11 companies out of 38 sample companies enjoy tax incentives more than other companies. Obviously, this result also confirmed that even with more tax incentives and exemptions, investors' decisions probably might not change, as there are other factors determining these behaviors, such as political stability and quota and duty free to the USA market (see section 5.5.2).

\subsubsection{Jordan Free Zones Corporation (JFZC)}

Companies located in any of the free zones can enjoy tax exemptions offered by JFZC law for the year 1984 and its amendment as well as from JIB law. Under JFZC law, companies enjoy the following incentives and exemptions:

$\checkmark \quad$ Exemption of Project's profits from income taxes for goods exported outside the Kingdom as well as transit trade, in addition to profits accruing from selling or transferring of goods inside the borders of the free zones

$\checkmark \quad$ Exempting salaries and allowances of non-Jordanian employees in projects established in the free zone from income and social service taxes

$\checkmark \quad$ Exempting imported goods or exported to parties other than domestic market from import fees, custom duties and all taxes and fees accrued thereon except services and rent charges

$\checkmark \quad$ Exempting buildings and real estate constructions built in the free zones from the licensing fees as well as from buildings and land taxes

According to table 5.32, the number of companies working in QIZs and enjoying tax exemption from JFZC were found to be 2 companies located in one zone. In addition to the above exemptions, it should be mentioned here that all QIZs companies enjoyed a package 
of tax incentives and exemptions from JIB. Moreover, companies can benefit from more tax incentives through combining between JIB and JFZC or between JIB and JIEC, depending on the project location either if it located within JFZC or JIEC.

\subsubsection{Factors Affecting Investor Decisions to Invest in QIZs}

In this section, the interviewees were asked to rank the most important factors for them to invest in the QIZs. Among these factors were the duty and quota free export to the USA market, the tax exemption, the political and economic stability, the investment climate, and the cheap labor. Table 5.33 clarifies the most important factors affecting investors' decision to invest in the QIZs. The Interviewees were asked to assess different alternatives such as (1: very low $\rightarrow$ 5: very high).

Table 5.33 indicates that the majority of investors in the QIZs considered the duty and quota free to export to USA market the most important factor behind their decision to invest in the QIZs. About 97 percent of the companies ranked this factor very high and the reminder 3 percent ranked the alternative high. The second most important factor that plays a big role in investors' decision is political stability. According to the data in table 5.33, around 55 percent of the respondents ranked the political stability very high and 21 percent only high. This is because Jordan is distinguished from other countries in the region by its stable political system. The third and fourth factors were ranked very high with 18 percent for the economic stability and 16 percent to the investment climate. Other respondents ranked the economic stability and investment climate with high and gave those two factors 21 percent and 16 percent respectively. The fifth factor that has been assumed to play the main role in the investors' decision to invest in the QIZs was tax exemption. This factor was ranked very high only by 13 percent of the respondents, while about 24 percent ranked it high. The sixth factor which was assumed to play importance role in the investors' decision, and the source of the comparative advantage that Jordan has, is cheap local labor. This factor considered competitive comparing with other countries in the region. Opposite to the expectation, only 8 percent of the respondents considered this factor important and ranked it very high and another 8 percent considered it high. The main reasons behind this unexpected result were the low productivity of local workers and the instability of workers (recalling information from section 5.2.7). 
Table 5.33: Main Factors Affecting Investors' Decision

\begin{tabular}{|c|c|c|c|c|c|c|c|c|c|c|c|c|}
\hline \multirow[b]{2}{*}{$\begin{array}{l}\text { Main Factors to } \\
\text { Invest in QIZ }\end{array}$} & \multicolumn{2}{|c|}{$\begin{array}{l}\text { Al Tajamouat } \\
\text { Industrial City }\end{array}$} & \multicolumn{2}{|c|}{$\begin{array}{c}\text { Al Hassan } \\
\text { Industrial } \\
\text { Estate }\end{array}$} & \multicolumn{2}{|c|}{$\begin{array}{c}\text { Al Dulayl } \\
\text { Industrial } \\
\text { Park }\end{array}$} & \multicolumn{2}{|c|}{$\begin{array}{c}\text { Al Hussein } \\
\text { Bin } \\
\text { Abdullah II } \\
\text { (Karak) }\end{array}$} & \multicolumn{2}{|c|}{$\begin{array}{c}\text { Cyber City } \\
\text { Park }\end{array}$} & \multicolumn{2}{|c|}{ Total } \\
\hline & $\begin{array}{c}1: \\
\text { Very } \\
\text { Low }\end{array}$ & $(\%)$ & $\begin{array}{c}\text { 2: } \\
\text { Low }\end{array}$ & $(\%)$ & $\begin{array}{c}3: \\
\text { Neutral }\end{array}$ & (\%) & $\begin{array}{l}\text { 4: } \\
\text { High }\end{array}$ & (\%) & $\begin{array}{c}5: \\
\text { Very } \\
\text { High }\end{array}$ & $(\%)$ & Total & (\%) \\
\hline $\begin{array}{l}\text { Duty and Quota } \\
\text { Free to USA } \\
\text { Market }\end{array}$ & 0 & 0 & 0 & $\overline{0}$ & 0 & 0 & 1 & 3 & 37 & 97 & 38 & 100.0 \\
\hline Tax Exemption & 3 & 8 & 6 & 16 & 15 & 39 & 9 & 24 & 5 & 13 & 38 & 100.0 \\
\hline Political Stability & 2 & 5 & 4 & 11 & 3 & 8 & 8 & 21 & 21 & 55 & 38 & 100.0 \\
\hline Economic Stability & 7 & 18 & 4 & 11 & 12 & 32 & 8 & 21 & 7 & 18 & 38 & 100.0 \\
\hline Investment Climate & 2 & 5 & 8 & 21 & 16 & 42 & 6 & 16 & 6 & 16 & 38 & 100.0 \\
\hline Cheap Labor Force & 25 & 66 & 3 & 8 & 4 & 11 & 3 & 8 & 3 & 8 & 38 & 100.0 \\
\hline
\end{tabular}

Source: Field Research

\subsubsection{Value of Tax Exemptions}

In the short term it is assumed that the fiscal effects of creating QIZs can be expected to be negative. While in the long term, with timing-out tax exemptions and the ability to induced economic activity surround the QIZs, the net fiscal effects of the QIZs might turn out to be positive. Table 5.34 explains the estimate of the amount of tax exemptions offered to the companies in QIZs from JIB, JFZC and JIEC. The possible responses were given and companies could select between different alternatives. About two thirds of the respondents (68.4 percent) estimate the amount of tax exemptions offered to them as more than US\$ 5 million, while for the reminder one third ( 29 percent) of respondents estimate the amount of tax exemptions offered to them to be less than US\$ 2.5 million.

It should be mentioned here that during the field research, it was rare for interviewees in some cases to reply to any questions, which asked them to give values or estimate amounts for different indicators such as tax exemptions, cost of production, amount of imports, and revenue. This is because they tended to lack confidence in the researcher and instead preferred to answer misleadingly. However, in our opinion the one third of interviewees who assumed that they received tax exemptions of less than US\$ 2.5 million should be treated as being misleading. This is because it is not possible under any circumstances that they got tax exemption less than US\$ 2.5 million. 
Table 5.34: Estimated Value of Tax Exemption

\begin{tabular}{|c|c|c|c|c|c|c|c|c|c|c|c|c|}
\hline \multirow[b]{2}{*}{$\begin{array}{l}\text { Value of Tax Exemption in } \\
\text { US\$ }\end{array}$} & \multicolumn{2}{|c|}{$\begin{array}{c}\text { Al } \\
\text { Tajamouat } \\
\text { Industrial } \\
\text { City }\end{array}$} & \multicolumn{2}{|c|}{$\begin{array}{c}\text { Al Hassan } \\
\text { Industrial } \\
\text { Estate }\end{array}$} & \multicolumn{2}{|c|}{$\begin{array}{c}\text { Al Dulayl } \\
\text { Industrial } \\
\text { Park }\end{array}$} & \multicolumn{2}{|c|}{$\begin{array}{c}\text { Al } \\
\text { Hussein } \\
\text { Bin } \\
\text { Abdullah } \\
\text { II (Karak) }\end{array}$} & \multicolumn{2}{|c|}{$\begin{array}{c}\text { Cyber City } \\
\text { Park }\end{array}$} & \multicolumn{2}{|c|}{ Total } \\
\hline & No. & $(\%)$ & No. & $(\%)$ & No. & $(\%)$ & No. & $(\%)$ & No. & $(\%)$ & No. & $(\%)$ \\
\hline Up to 1 Mill & 3 & 18.8 & 1 & 11.1 & 1 & 11.1 & 1 & 50 & 0 & 0 & 6 & 15.8 \\
\hline From 1 Mill to 2.5 Mill & 4 & 25.0 & 1 & 11.1 & 0 & 0.0 & 0 & 0 & 0 & 0 & 5 & 13.2 \\
\hline From 2.5 Mill to 5 Mill & 0 & 0.0 & 0 & 0.0 & 0 & 0.0 & 0 & 0 & 0 & 0 & 0 & 0.0 \\
\hline More than 5 Mill & 9 & 56.3 & 7 & 77.8 & 7 & 77.8 & 1 & 50 & 2 & 100 & 26 & 68.4 \\
\hline Missing & 0 & 0.0 & 0 & 0.0 & 1 & 11.1 & 0 & 0 & 0 & 0 & 1 & 2.6 \\
\hline Total & 16 & 100 & 9 & 100 & 9 & 100 & 2 & 100 & 2 & 100 & 38 & 100 \\
\hline
\end{tabular}

Source: Field Research

\subsubsection{The effects of QIZs on Poverty Alleviation}

According to international trade theories, particularly the Heckscher-Ohlin theorem, free trade will raise the welfare of countries engaged in the free trade relative to autarky. In other words, countries will be better off when adopting free trade and liberalized its economy. Once the country adopts free trade, and using the abundant factor in it, the free trade will be more profitable to it through trade with other countries. Following the StolperSamuelson theorem, an increase in the price of the good traded largely by the country, will cause an increase in the price of the factor used in it intensively. In many developing countries, the abundant factor is the unskilled labour. When free trade takes place in developing countries, it is assumed that the unskilled workers will benefit more than others. For example, the intensive factor in Jordan is the unskilled labour and this factor is used intensively to produce manufacturing goods for exports from the QIZs. According to Bhagwati and Srinivasan (2002), countries that follow free trade liberalisation and exportoriented strategy benefit the poor people in these countries, through affecting the wage of unskilled employees, which are considered to be the abundant endowment factors in developing countries. Following the results of Bhagwati and Srinivasan unskilled local labour in the QIZs is assumed to benefit from working in the QIZs. Therefore, the occurrence of free trade through QIZs should help to reduce poverty incidence in countries which use their comparative advantage to export labour intensive goods. The main channels via which QIZs might affect the poor people in the country flow, from creating jobs for unskilled workers. QIZs help to create jobs for unskilled workers in the country (see section 5.4.2.4 for workers characteristics). The majority of workers in the QIZs are young, single females from rural areas. These jobs which have been created for them by 
QIZs provide opportunities to increase income otherwise they will not get it. The status of these young females is often enhanced through improving their economic conditions. According to the field research, 70 percent of local employees were found to be female in the year 2004, the majority of them without prior work experience. Unemployment rate among such females stands at around 95 percent. Considering the US\$ 150 average income for unskilled workers in the QIZs, local female workers benefit with more than US\$ 1.3 million as a monthly income. This income plays a big role in enhancing family income for a lot of families, providing a means for poverty alleviation. Overall, QIZs drive income to unemployed workers and provide them with income in another case; they will not be able to get it if they are still unemployed. Nevertheless, despite the extreme work conditions in the QIZs, the majority of female workers capable to preserve this opportunities and continue working. Recent data published by MOP shows that poverty incidence decreased from 21.3 percent in 1997 to 14.2 percent in 2002 (see table 5.35). If more attention is given to local workers in the QIZs, the number of poor people will decrease dramatically. The pessimistic view comes from the fact that 60 percent of employees in the QIZs were foreign. Those foreign workers participate negatively in benefiting local employees through working in the QIZs, and decreasing their opportunities to enhance their work conditions and standard of living. In general, QIZs contribute positively to the welfare of a part of the poor cohorts in the country by increasing employment opportunities for females and their unskilled male counterparts, for whom the poverty incidence can be expected to be high (Pernia and Quibria 1999).

Table 5.35: Jordan Poverty Assessment 2004

\begin{tabular}{|l|c|c|}
\hline & $\mathbf{1 9 9 7}$ & $\mathbf{2 0 0 2 / 2 0 0 3}$ \\
\hline Absolute poverty line (US\$) & 516 & 553 \\
\hline Poverty Incidence & $21.3 \%$ & $14.2 \%$ \\
\hline Poverty gab & $5.3 \%$ & $3.3 \%$ \\
\hline Severity of Poverty & $2.0 \%$ & $1.1 \%$ \\
\hline
\end{tabular}

Source: Ministry of Planning 


\subsection{Conclusions}

The survey of QIZs recipients gives evidence on the characteristics of the scheme and its effects. In particular, it gives information on the status of the interviewees, the companies, the start-up stage, the nature of projects, and the fiscal and economic effects of the QIZs companies on the economy. Data on the investor nationality shows that 79 percent of investors are from Asian countries, 7.9 percent are local and 2.6 are Israelis. Gender composition shows that about 70 percent of local employees are female, while this proportion for foreign employees stands at 79 percent. The maximum age of the companies working in the QIZs is around 6 years old, while the minimum age is 2 years. Characteristics of the sample companies show that around two-thirds of the companies were subsidiary branches of mother companies located outside the country. Only a few companies in this sample can be considered small and medium companies, because most of the sample companies were large scale companies with more than 100 employees.

The start-up stage capital used by one third of the sample companies was generally more than US\$ 5 million, indicating that the firms are generally large size. Also at this stage it is apparent that the self-finance and partners were the principal financial sources for capital at the start-up stage.

Most of the companies in the QIZs employed local and foreign employees. About 60 percent of the employees were found to be foreigners, only 40 percent of the employees were locals. The study shows a diminution in the number of local employees. After they made up 49 percent from the total of personnel in the year 2002, this proportion decreased to about 40 percent in the year 2004. The vast majority of sample companies stressed the difficulties in finding and hiring local employees. About 78.9 percent of the sample companies agreed that it is difficult to hire local employees. This reflects the increasing number of foreign employees against locals. According to the majority of the sample companies, most local employees were unstable and they transfer from one company to another. Around 20 local employees moved from one company to another every month. In spite of all this, 95 percent of local employees were unemployed. Skilled and unskilled employees characterized in the QIZs, 62.7 percent of total employment was considered skilled and 37.3 percent considered unskilled. According to the vast majority of sample companies, local employees are considered to be unskilled and foreign employees to be the 
skilled. Only 5 percent of local employees are considered to be skilled. This is very surprising, as the QIZs are meant to transfer technology and know-how to local employees. Nevertheless, the companies themselves offered unskilled jobs to local employees because they consider them unproductive as foreign workers. Wage structure in the zones differs between local employees and foreign employees. This difference depends on the companies themselves on one hand and the government policy on the other hand. For example, the questionnaire results shows that companies differentiate between skilled and unskilled employees, where unskilled employees are paid the minimum wage and skilled employees are paid at higher rate than the minimum wage. Regarding work conditions in the zones, the study shows that both foreign and local workers face a bad work conditions in the QIZs companies. Regarding vocational training for local employees, the study shows weaknesses from both companies and vocational centers in providing local employees with the qualifications and skills to adapt to this kind of work in the future.

The survey analysis shows that the majority of investors in the QIZs consider the duty and quota free to export to USA market the most important factor behind their decision to invest in the QIZs. About 97 percent of companies rank this factor very high and the reminder 3 percent rank the alternative high. The second important factor that plays a big role in the investor decision is the political stability. According to 55 percent of the respondents ranked the political stability very high and 21 percent high. This is because Jordan is distinguished from other countries in the region by its stable political system. The third and fourth factors to be ranked very high to the economic stability and investment climate with around 18, 16 percent respectively. The fifth factor that has been assumed to play the main role in the investor's decision was tax exemption. This factor was ranked very high only by 13 percent of the respondents, while about 24 percent ranked it high. The sixth factor was cheap local labor. This factor was also assumed to play an important role in the investors' decision, as local labor is considered to be competitive with other countries in the region. Contrary to the expectation, only 8 percent of the respondents consider this factor important and ranked it very high.

More than two-thirds of the sample firms have tax exemption of more than US\$ 5 million, and one third have tax exemption below US\$ 2.5 million. According to the questionnaire results, the QIZs failed to create any backwards linkages or induce local companies to benefit from the QIZs, therefore the tax revenues raised by these companies were expected 
to be very low and insignificant. The analyses of Balance of Payments show two main effects from the QIZs, the first effect on the trade balance and the second one on the current transfer. On the trade balance side, net export earning shows negative results in the first years of establishment, then after that it started to witnessed positive results and increase in the foreign currency earning. On the current transfer side, around one quarter of the outflow of worker remittances in the year 2004 was due to the QIZs comparing with around 5 percent in the year 2000. The causal relationship between exports and economic growth were found to be unidirectional from economic growth to exports. The contribution of QIZs in reducing unemployment rate shows only a slight impact on the overall unemployment rate in the country. The other effects of the QIZs on the local economy are accounted for by the multiplier impacts. The analysis of the multiplier of QIZs shows a limitation in spur ripple effects to other sectors in the economy.

The foregone revenues are considered to be one of the main negative effects of the QIZs on the local economy, as it does not receive high importance from the investors. Overall, in the short run the fiscal effects of creating QIZs can be expected to be negative. While in the long run, with timing out of tax exemptions and induced economic activity surround the QIZs the net fiscal effects of the QIZs, might turn out to be positive. This of course depends on the continuity of recent companies to stay working in the future.

Finally, the survey analysis of the companies operating in the QIZs shows that the change from working under the QIZs agreement to the working under the Free Trade Agreement (FTA $)^{69}$ is more preferable to most of the investors. This is because of the possibility of avoiding the imports of 8 percent of the contents from Israel and the sovereignty to import intermediate goods from anywhere in the world with cheap prices.

Having described the nature of the sample survey of firms and the nature of the data at our disposal, the econometric analysis of the survey data is carried out in the next chapter, where the variables are given labels. Not all of the survey data are subsequently included in the statistical analysis, especially where the data is subjective in nature, so that some of the variables do not have labels, while others subsequently are excluded because they prove not to be very useful.

\footnotetext{
69 The FTA is the Free Trade Agreement between the government of US and the government of Jordan in which Jordanian goods can enter the USA market duty and quota free.
} 
Figure 5.1: Investors' Nationality in the QIZs

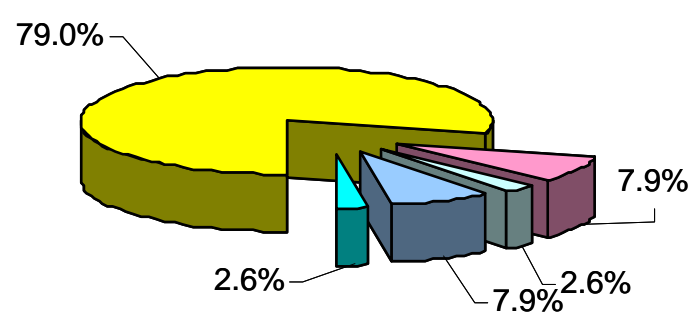
$\square$ Far East
$\square$ European
$\square$ Turkish
$\square$ Jordanian
$\square$ Israeli

Figure 5.2: Value of Investment in Million US\$

2004

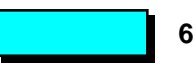

2003

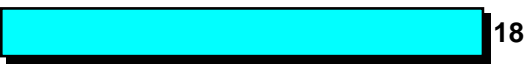

2002

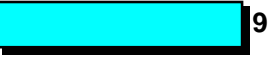

2001

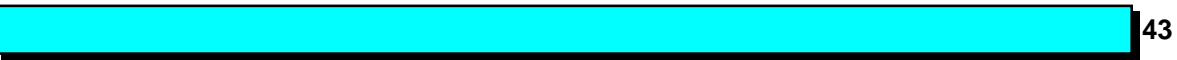

2000

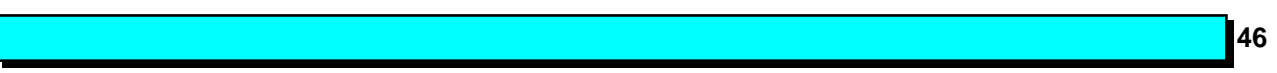

Figure 5.3: Status of Companies in the QIZs

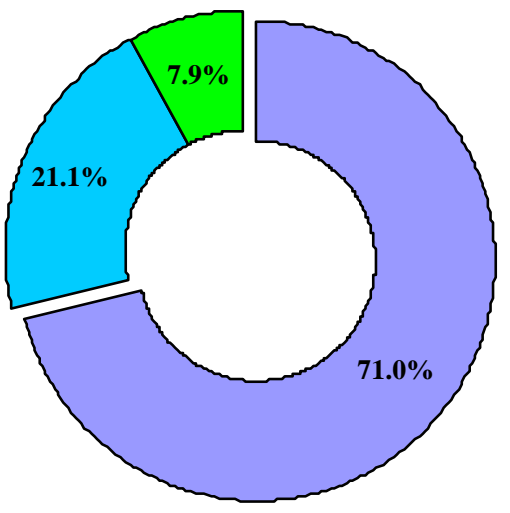


Figure 5.4: Location of QIZs

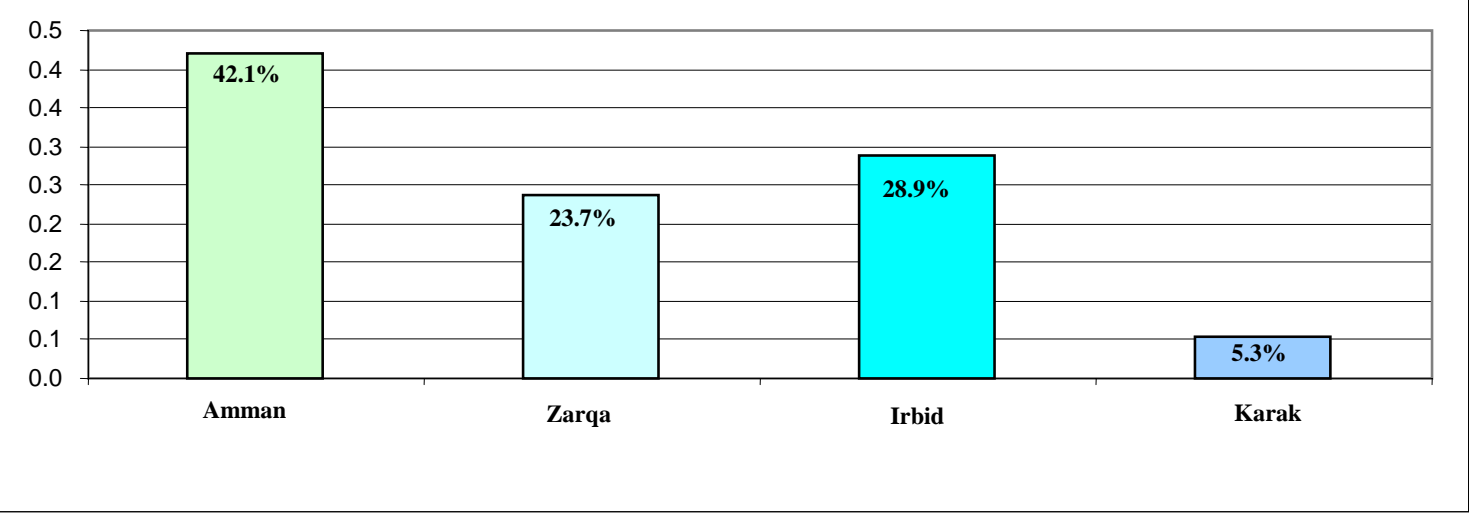

Figure 5.5: Share of Local and Foreign Employees in the QIZs

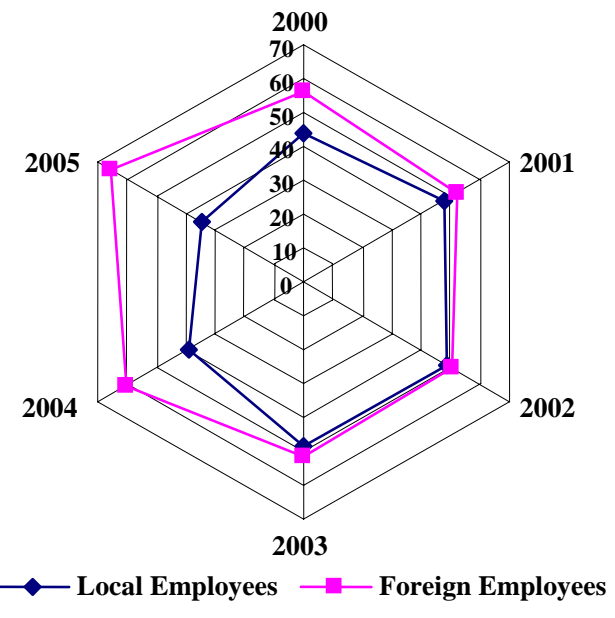

Figure 5.6: No. of Local and Foreign Employees in the QIZs

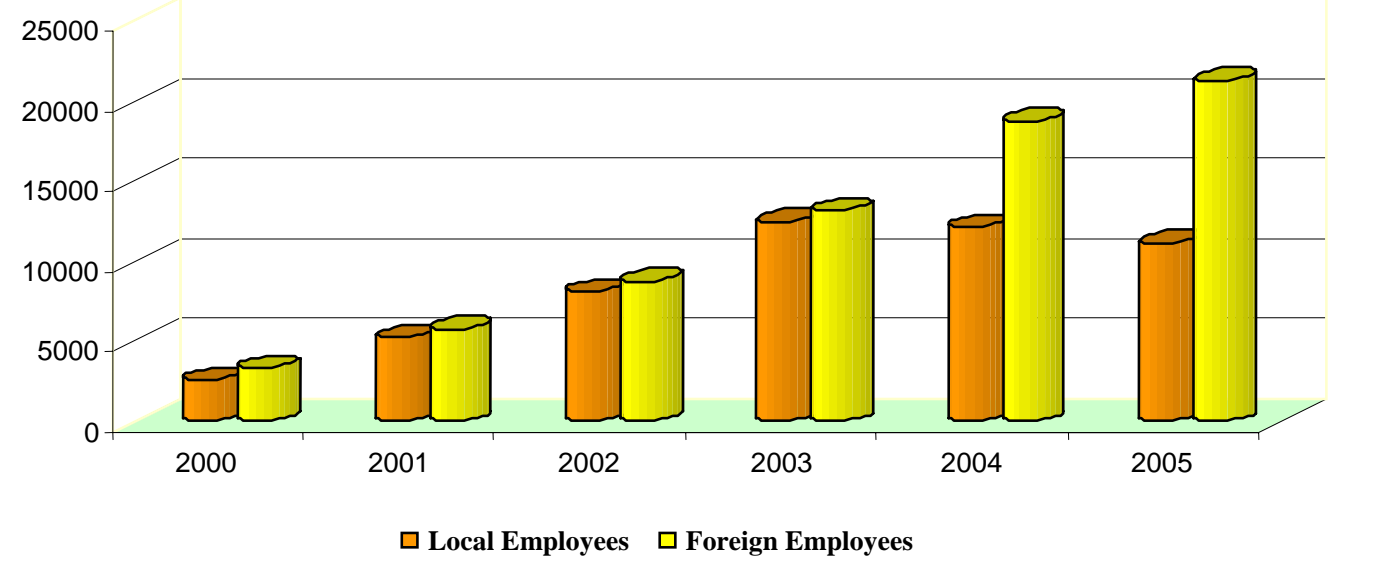




\section{CHAPTER 6}

\section{QUANTITATIVE ANALYSIS OF THE SURVEY RESULTS}

\subsection{Introduction}

There have been very few attempts to evaluate the role of the Qualifying Industrial Zones (QIZs) on the Jordanian economy. These attempts that have been done tend to highlight and overvalue the impact of such zones on the local economy. Moreover, most of these attempts used conflicting data and information, which can not reflect all of the dimensions of these zones. This chapter provides a more rigorous analysis of the survey data collected on the QIZs in Jordan in order to determine its effect on the local economy. These data and the method of collection have been described in the previous two chapters (chapter four and five). Overall, this represents the first attempt to rigorously evaluate and assess the phenomenon of QIZs.

This chapter undertakes a detailed statistical analysis of the data obtained from the survey. It represents a development of the purely descriptive analysis involving the survey data in Chapter 5. It has the advantage of utilizing regression techniques, which enables many of the variables to be considered together in order to identify the key effects of creation the QIZs. The OECD (2000) report states that a combination of qualitative and quantative analyses allow policy-makers and analysts to better understand the differences and helps to increase the credibility of evaluation results. The purpose is to consider the effect of QIZs companies characteristics on the economy. It includes an empirical analysis of the effects of such things as: the effect on economic growth, the effect on per capita income, the effect on unemployment, the effect on Balance of Payment, the effect on poverty alleviation and the effect on the fiscal side of the budget. However, some of the analyses of this chapter are from the companies' view-point, because it relies on subjective data gathered from the survey. 


\subsection{The Variables}

The data relate to 38 companies that were interviewed as part of the survey of companies in the five main zones (see Chapter 4). The quantitative analysis of these data does not allow us to use all of the variables in the survey; this is because some data are not relevant to the empirical analysis in this chapter. Some of the variables are highly subjective in nature and others have a large number of missing cases. However, Chapter 5 includes a qualitative analysis for all of the variables gathered from the survey. The purpose of this chapter is to undertake a quantitative analysis, which will improve the main finding on the analysis of Chapter 5 . The variables used in this chapter are divided into different groups, and these are considered below. Other variables have been used as well in order to clarify the whole effects on the overall economy. Among the main variables that have been used were: per capita income, GDP, exports, imports, trade balance, manufacturing exports, income inequality (measured by gini coefficients), poverty line and worker remittances. There are 38 potential observations for each variable, but due to non-response there are some missing observations.

\subsection{Model Estimation}

To improve on the cross-tabulation of the previous chapter, in this analysis we employ regression techniques. A substantial advantage of this is that it gives the evaluator an indication of probable casual relationships between variables, and it allows this person to make inferences about these relationships within a multivariate setting. It also allows the direction and the magnitude of changes to be established. The data are categorical in nature and they can be expressed as probabilities. In order to achieve the research objectives, we explored several models, and every model is designed to examine the potential effect of QIZs on the economy from different aspects. For instance, the effects on the economic growth has been examined by using Granger-causality analysis, while the impact of the QIZs on the per capita income, balance of payment, poverty, has been tested by developing both fixed effects and random effects models. In the following, there is an in-depth description of the models that have been used as well as the main results that have been obtained from the analysis. 


\subsection{Model One: The Effects of QIZs on Economic Growth}

\subsubsection{Introduction}

The role of exports on economic growth has been subject to extensive empirical investigation by many researcher and studies (Balassa, 1978; Krueger, 1978; Jung and Marshall, 1985; Ram, 1987; Reizman et al 1996). This issue is still considered to be one of the main issues that face development strategies for developing countries. Several studies (Balassa, 1978; Krueger, 1978; Ram, 1987) found a high link between export and economic growth as international trade and development theory indicates. Other studies have reached negative and mixed results (stokes and Jaffy, 1982; Kunst and Marin, 1989; Subasat, 2002). The question that remains to be answered is; to what extent does an increase in exports lead to economic growth? Or does economic growth lead to a growth in exports? Until now, no precise answers were given to this question and the debate among researchers still remains. The export-led growth hypothesis postulates that exports activity and expansion lead to economic growth. While this hypothesis implies that economic growth induce trade into the country. A search of the large body of empirical evidence in the literature reveals that there appears to be no agreement on the existence of a relationship between exports and economic growth, if it exists at all. According to Gilles and Williams (2000), the nature of such a relationship is doubtful. Moreover, the direction of causation between exports and economic growth is still not clear in the empirical studies, when it investigates the relationship between export and economic growth for same countries. For instance, Krueger (1985) support the hypothesis of exports led growth for some East Asian countries. Whereas Darrat (1986) reexamination of the export-led growth hypothesis for these countries did not support the export led growth hypothesis. Other studies, like (Michealy, 1977; Balassa, 1978; Ram, 1987) found positive relationship between exports and economic growth. But these studies were criticized regarding the method of investigation. According to Jung and Marshal (1985), using regressions to support export-led growth hypothesis is questionable due to the fact that regression techniques cannot determine the direction of causality. On the other hand, Tybout (2003) examined the initial studies which examine the relationship between 
exports and economic growth and found that a positive relationship is not surprising, because exports consider one of the components of the output in the income identity.

Nethertheless, the conflict between the studies that investigate the relationship between exports and economic growth could be distinguished according to the following criteria: (1) Using different methods and techniques, (2) Using different variables, (3) Using different periods of time. Some studies examine the relationship by using the rank correlation coefficient, OLS regression techniques and/or the granger causality test.

Dodaro (1993), Reizman et al (1996), Abu-Qarn and Abu Bader (2001) and Abul Foul (2004) examine the export-led growth hypothesis in Jordan. These studies track and investigate the causality relationship between exports and economic growth by addressing the issue of causality between exports and economic growth. The results of these studies were mixed, due to the use of different periods for the time series, different methods to investigate the causality between the two variables, and more than two variables. This study examines the causality relationship between export and economic growth through the use of annual time series data for Jordan during the period 1980 2004.

\subsubsection{Literature Review}

The impact of exports on economic growth has been discussed during the last three decades by many researchers (Emery, 1967; Kraves, 1970; Balassa, 1978; Krueger, 1978; Feder, 1983, etc). The literature that examine this relationship is extensive, and most pertain to developing countries. The results of these studies are mixed and unclear for both the relationship between exports versus economic growth and the direction of causality. A comprehensive summary of these studies can be found in, (Balassa, 1985; Greenaway and Sapsford, 1994; Riezman et al 1996; Shan and Sun, 1998 and MedinaSmith, 2001).

A few studies examine the causality between exports and economic growth in Jordan. Particularly, (Dodaro, 1993; Reizman et al 1996; Abu-Qarn and Abu Bader, 2001; and Abul Foul, 2004). Dodaro (1993) employed a bivariate causality test on real GDP growth and growth of real exports of goods and non-factor services over the period from 1967- 
1987. He did not find any evidence of causality between growth and exports in the cases of Algeria, Jordan, Morocco, Sudan and Tunisia. Reizman et al (1996) found support for export-led growth when using granger causality test in the cases of Algeria, Egypt, and Tunisia. But they did not find any evidence of causality in the cases of Israel, Jordan, Morocco, Sudan, or Turkey. On the other hand, when they include imports in the model they found support to export-led growth for Jordan and Sudan only. Abu-Qarn and Abu Bader (2001) examine the export-led growth for nine of the Middle East and North African (MENA) countries in three-variable vector autoregressive and error correction models. They found that export-led growth are not valid in the vast majority of countries, when considering total exports only. While they found that export-led growth strategy is only valid for countries with high share of manufacturing exports in total merchandise exports, when they were considering manufacturing exports instead of total export. Abul Foul (2004) examined the export-led growth hypothesis in Jordan over the period 19761997. Three bivariate VAR models have been applied and his empirical results indicate a unidirectional causation from exports to output.

\subsubsection{Methodology}

This study used annual data to examine the causality between exports and economic growth. The variables which were used are a) Real Gross Domestic Product (GDP), b) domestic exports, c) exports of good and services, d) manufacturing exports and e) imports. All data are in real terms and obtained from the Central Bank of Jordan covering the period $1980-2004$ (see appendix 6). Following are the quantities tests which used in this study and the empirical results.

\subsubsection{Granger Causality Test}

An econometric technique of whether or not an event leads to other events is known as granger test (Granger, 1969). The definition of causality in the Granger sense is based on the idea that the past cannot be caused by the present or future. Hence, if an event occurs before another event, causality can only occur from the first event to the second one. Granger formulated a test statistic to test whether movements in one variable systematically precede movements in another variable. According to Granger the 
outcomes of the causal relationship between economic growth and exports summarized as the following: 1) A unidirectional causality from exports to economic growth; 2) A unidirectional causality from economic growth to exports; 3) bi-directional causality between exports and economic growth; and 4) no casual relationship between the two variables.

There are different ways to implement a test of Granger causality. For a simple bi-variate and multi-variate model of the type used in this analysis, the pattern of causality can be identified by estimating regressions on exports and GDP, using the current and past values of exports and GDP as regressors and by testing the appropriate hypotheses. For this study, the model involves estimating the following equations:

$\operatorname{expt}=\mathrm{C}_{1}+\alpha 0 \mathrm{GDP}+\sum_{\mathrm{i}=1}^{\mathrm{k}} \alpha_{\mathrm{i}} \mathrm{GDP}_{\mathrm{t}-\mathrm{I}}+\sum_{\mathrm{i}=1}^{\mathrm{k}} \beta \mathrm{j} \operatorname{expt-i}+\varepsilon \mathrm{t}$

and

$\mathrm{GDP}_{t}=\mathrm{C} 2+\gamma 0 \operatorname{expt}+\sum_{\mathrm{i}=1}^{\mathrm{k}} \phi_{\mathrm{iGDP}}-\mathrm{I}+\sum_{\mathrm{i}=1}^{\mathrm{k}} \gamma \mathrm{j} \operatorname{expt-i}+\mathrm{ut}$

Where GDP is the gross domestic product and exp is exports. The coefficients $\alpha_{i}$ and $\beta_{j}$ in equation 1 describe the effects of $k$ current and past values of GDP and export on export; $\phi_{i}$ and $\gamma_{j}$ describe the effects of k current and past values of GDP and export on GDP, the $\varepsilon_{\mathrm{t}}$ and $v_{\mathrm{t}}$ are two independent error terms. There are four possible outcomes of this Granger causality test:

1) Unidirectional causality from export to GDP (denoted exp $\rightarrow G D P$ ) if $H_{1}$ is rejected, but $\mathrm{H}_{2}$ is not rejected.

2) Unidirectional causality from GDP to export (denoted GDP $\rightarrow$ exp) if $\mathrm{H}_{2}$ is rejected, but $H_{1}$ is not rejected.

3) Bidirectional or feedback causality (denoted GDP ↔exp) if both $\mathrm{H}_{1}$ and $\mathrm{H}_{2}$ are rejected.

4) GDP and exp are independence if both $\mathrm{H}_{1}$ and $\mathrm{H}_{2}$ cannot be rejected.

To decide whether or not to reject the null hypothesis $H_{1}$ or $H_{2}$ of the Granger causality test, Granger applies the $F$ test of overall significance, computed as:

$$
\mathrm{F}=\frac{\left(\mathrm{RSS}_{\mathrm{R}}-\mathrm{RSSUR}\right) / \mathrm{m}}{\mathrm{RSSUR} /(\mathrm{T}-\mathrm{K})}
$$


Where RSSUR is the unrestricted residuals sum of squares from the estimated Equation 1 or Equation 2 and $R S S R$ is the restricted residuals sum of squares from the estimated equation 1 or equation 2 under the null hypothesis. F statistics follows $\mathrm{F}$ distribution with $\mathrm{m}$ and $(\mathrm{T}-\mathrm{K})$ degrees of freedom, where $\mathrm{m}, \mathrm{k}$ and $\mathrm{T}$ are numbers of regressors (including the constant term) in the right-hand side of Equation 1 or 2 and the sample size. If the computed $F$ value exceeds the critical $F$ value at chosen level of significance, then the null hypothesis is rejected, implying evidence of causality. Otherwise, the null hypothesis is accepted, and no causal relationship is implied.

In order to perform granger causality test, we should make two steps regarding the time series data. The first step is to deal with the stionarity of data whether the data have unit root or not. The second step is to examine the long run relationship under the cointegration test.

\subsubsection{Unit Root Test}

The first step of time series model building is to examine how stationary the time series is (unit root). One way to test whether the time series is stationary or non stationary is to use the Dickey-Fuller and Augmented Dickey-Fuller tests.

$\mathrm{Yt}_{\mathrm{t}}=\mathrm{pyt}-1+\mathrm{Xt} \partial+\varepsilon \mathrm{t}$

where, Xt are optional exogenous regressors that may consist of constant, or a constant and a trend. $\rho$ and $\partial$ are parameters to be estimated and $\varepsilon t$ assumed to be white noise. If $|\rho| \geq 1$, then $\mathrm{y}$ is a nonstationary series, and the variance of y increases with time and approaches infinity. If $|\rho|<1, \mathrm{y}$ is a (trend) stationary series. Thus, the hypothesis of (trend) stationarity can be evaluated by testing whether the absolute value of $\rho$ is strictly less than one.

The standard DF test is carried out by estimating equation (4) after subtracting $\mathrm{yt}_{\mathrm{t}-1}$ from both sides of the equation:

$\Delta \mathrm{yt}-1=\alpha \mathrm{yt}_{\mathrm{t}-1}+\mathrm{X}_{\mathrm{t}} \partial+\varepsilon \mathrm{t}$

Where $\alpha=\mathrm{p}-1$. The null and alternative hypotheses may be written as:

H0: $\alpha=0:$ Non stationary Time-Series (Unit Root)

H1: $\alpha<0$ : Stationary Time-Series (No Unit Root) 
The simple Dickey-Fuller unit root test described above is valid only if the series is integrated in order one or AR (1) process. If the series is correlated at higher order lags, then the assumption of white noise disturbances $\varepsilon t$ is violated. The Augmented DickeyFuller (ADF) test constructs a parametric correction for higher-order correlation by assuming that the $y$ series follows the order of integration AR ( $p$ ) process, and adding the $p$ lagged difference terms of the dependent variable $y$ to the right hand side of the test regression:

$\Delta \mathrm{yt}_{\mathrm{t}}=\alpha \mathrm{yt}-1+\mathrm{Xt} \partial+\beta 1 \Delta \mathrm{yt}-1+\beta 2 \Delta \mathrm{yt}-2+\ldots .+\beta \mathrm{p} \Delta \mathrm{yt}-\mathrm{p}+\mathrm{vt}$

While using ADF test there are two practical issues. First, we must choose whether to include exogenous variables in the test regression. We have the choice of including a constant, a constant and a linear time trend, or neither, in the test regression. Second, we will have to specify the number of lagged difference terms to add to the test regression.

\subsubsection{Cointegration Test}

After we ensure that the time series are stationary and integrated in order (1), the next step is to examine the longitudinal relation between export and economic growth by conducting the contigration test. The most common test for cointegration is the cointegration test using the methodology developed by Johansen (1991, 1995a). The testing hypothesis is the null hypothesis of no cointegration against the alternative hypothesis that there is cointegration between the variables.

The purpose of the cointegration test is to determine whether a group of non-stationary series is cointegrated or not. The presence of a cointegrating relation forms the basis of the Vector Error Correction (VEC) specification. Consider a Vector Autoregression (VAR) of order $p$ :

$\mathrm{Yt}_{\mathrm{t}}=\mathrm{A} 1 \mathrm{Yt}-1+\ldots+$ Ap $\mathrm{Yt}_{\mathrm{t}-\mathrm{p}}+\mathrm{BXt}+\varepsilon \mathrm{t}$

Where $Y t$ is a $K$ vector of non-stationary $I(1)$ variables, $X t$ is a $d$ vector of deterministic variables, and $\varepsilon$ is a vector of innovations. We can rewrite this VAR as

$\Delta y t=\Pi \Delta y t-1+\sum_{i=1}^{p-1} r i \Delta y t-i+B x t+\varepsilon t$ 
where,

$\Pi=\sum_{i=1}^{p} A_{i}-I, \quad r i=\sum_{j=i+1}^{p} A_{j}$

Granger's representation theorem asserts that if the coefficient matrix $n$ has reduced rank $r<k$, then there exist $K x r$ matrices $\alpha$ and $\beta$ each with rank $r$ such that $n=\alpha \beta$ and $\beta$ yt is $I(0), r$ is the number of cointegrating relations (the rank) and each column of $\beta$ is the cointegrating vector. As we will explain below, the elements of $\alpha$ are known as the adjustment parameters in the VEC model. Johansen's method is to estimate the $n$ matrix from an unrestricted VAR and to test whether we can reject the restrictions implied by the reduced rank of $n$.

\subsubsection{Empirical Results}

ADF test was used to examine the existence of unit root in the time series variables. We conduct ADF test on levels as a first step .Table 6.1 shows the results of the test.

Table 6.1: ADF Test Result for Levels

\begin{tabular}{||l|l|l|c|c|l||}
\hline \multirow{2}{*}{ Variables } & \multirow{2}{*}{ T. Statistics } & \multicolumn{3}{|c|}{ Critical Value } & \multirow{2}{*}{ P. Value } \\
\cline { 3 - 5 } & & $\mathbf{1 \%}$ & $\mathbf{5 \%}$ & $\mathbf{1 0 \%}$ & \\
\hline L RGDP & -0.311874 & -3.737853 & -2.991878 & -2.635542 & 0.9093 \\
\hline L RDE & -0.596796 & -3.737853 & -2.991878 & -2.635542 & 0.8538 \\
\hline L RI & -0.569050 & -3.737853 & -2.991878 & -2.635542 & 0.8601 \\
\hline L REGS & -0.326553 & -3.808546 & -3.020686 & -2.650413 & 0.9044 \\
\hline L RME & 0.489075 & -2.717511 & -1.964418 & -1.605603 & 0.8095 \\
\hline
\end{tabular}

Note: LRGDP is log real GDP, LRDE is log real domestic exports, LRI is log real imports, LREGS is log real export of goods and services and LRME is log real manufacturing export.

The ADF test results in table 6.1 demonstrate that the time series for the variables have a unit root (non stationary), which means that the null hypothesis, that the time series has a unit root, cannot be rejected and the variables are non-stationary.

The next step to deal with non-stationary time series, in order to continue to examine the long run relationship and conduct cointegration test, is to take the first difference for all variables and conduct ADF test another time to ensure that the time series are stationary. 
Therefore, in this case the order of integration is I(1) for all the variables. Table 6.2 shows the results of ADF test on differences.

Table 6.2: ADF Test Result for First Differences Series

\begin{tabular}{||l|l|l|l|l|l||}
\hline \multirow{2}{*}{ Variables } & \multirow{2}{*}{ T. Statistics } & \multicolumn{3}{|c|}{ Critical Value } & \multirow{2}{*}{ P. Value } \\
\cline { 3 - 5 } & & \multicolumn{1}{|c|}{$\mathbf{1 \%}$} & $\mathbf{5 \%}$ & $\mathbf{1 0 \%}$ & \\
\hline L RGDP & -3.749160 & -2.669359 & -1.956406 & -1.608495 & 0.0007 \\
\hline L RDE & -4.829753 & -3.752946 & -2.998064 & -2.638752 & 0.0009 \\
\hline L RI & -4.017736 & -2.669359 & -1.956406 & -1.608495 & 0.0003 \\
\hline L REGS & -5.479634 & -3.752946 & -2.998064 & -2.638752 & 0.0002 \\
\hline L RME & -6.571951 & -4.728363 & -3.759743 & -3.324976 & 0.0005 \\
\hline
\end{tabular}

Note: LRGDP is log real GDP, LRDE is log real domestic exports, LRI is log real imports, LREGS is log real export of Goods and services and LRME is log real manufacturing export.

In the second ADF test we re-examined the null and alternative hypothesis as following:

Null hypothesis Ho: time series have unit root (non stationary) Alternative hypothesis $\mathrm{H}_{1}$ : time series have no unit root (stationary)

Table 6.2 shows that the null hypothesis can be rejected in all levels of significants for all variables. That means that we can accept the alternative hypothesis. Therefore, we can conclude that the first differences time series are stationary series.

After we ensure that the data are integrated in order one, we perform the coitegration test. The results of Johansen cointegration test are shown in table 6.3.

Table 6.3: Johansen Cointegrated Test (old)

\begin{tabular}{||l|l|l|l|l|l|l|l||}
\hline $\begin{array}{c}\text { cointegration } \\
\text { Vectors } \\
\mathbf{r}\end{array}$ & Eigenvalue & $\begin{array}{c}\text { Trace } \\
\text { Statistic }\end{array}$ & $\begin{array}{c}\mathbf{5 \%} \\
\text { Critical } \\
\text { Value }\end{array}$ & $\begin{array}{c}\mathbf{1 \%} \\
\text { Critical } \\
\text { Value }\end{array}$ & $\begin{array}{c}\text { Max- } \\
\text { Eigen } \\
\text { Statistic }\end{array}$ & $\begin{array}{c}\mathbf{5 \%} \\
\text { Critical } \\
\text { Value }\end{array}$ & $\begin{array}{c}\mathbf{1 \%} \\
\text { Critical } \\
\text { Value }\end{array}$ \\
\hline $\mathrm{r}=0$ & 0.706731 & 65.2634 & 68.52 & 76.07 & 28.21326 & 33.46 & 38.77 \\
\hline $\mathrm{r}=1$ & 0.506892 & 37.0502 & 47.21 & 54.46 & 16.26161 & 27.07 & 32.24 \\
\hline $\mathrm{r}=2$ & 0.415952 & 20.7885 & 29.68 & 35.65 & 12.36877 & 20.97 & 25.52 \\
\hline $\mathrm{r}=3$ & 0.188641 & 8.41982 & 15.41 & 20.04 & 4.808041 & 14.07 & 18.63 \\
\hline $\mathrm{r}=4$ & 0.145325 & 3.61178 & 3.76 & 6.65 & 3.611780 & 3.76 & 6.65 \\
\hline
\end{tabular}

Note: LRGDP is log real GDP, LRDE is log real domestic exports, LRI is log real imports, LREGS is log real export of goods and services and LRME is log real manufacturing export. *(**) denotes rejection of the hypothesis at the $5 \%(1 \%)$ level. Trace test indicates no cointegration at both $5 \%$ and $1 \%$ levels. Max-eigenvalue test indicates no cointegration at both $5 \%$ and $1 \%$ levels.

The results in table 6.3 denote that both trace test and max eigen test reject the hypothesis that there are cointegration between domestic export and economic growth, since both the null that $(r=0,1,2,3,4)$ are rejected. In addition, there is also no relationship among the variables in the long run. The final step in our analyses is concerned with conducting the 
granger causality test. Due to the fact that this test is sensitive to the number of lags, we start by choosing a higher number of lags until we reach the reasonable lag length that consists with our notion. As can be seen from table 6.4, the hypothesis that economic growth is not a causal factor on exports can be rejected at the 5 percent significance level. From this we can conclude that the direction of causality is from economic growth to exports and not vise versa. On the other hand, there are bidirectional causality between manufacturing exports and domestic exports, and there is unidirectional causality from domestic exports to export of goods and services. The results in table 6.4 shows also that there is a unidirectional causality from manufacturing exports to imports, which indicate the role of exports in increasing imports.

Table 6.4: Granger Causality Test Results (old)

\begin{tabular}{|c|c|c|}
\hline Null Hypothesis & F-Statistics & Probability \\
\hline LRGDP does not Granger Cause LRDE & 4.16964 & 0.05391 \\
\hline LRDE does not Granger Cause LRGDP & 1.31616 & 0.26418 \\
\hline "LREGS does not Granger Cause LRDE & 1.72758 & 0.20290 \\
\hline LRDE does not Granger Cause LREGS & 3.57104 & 0.07268 \\
\hline LRME does not Granger Cause LRDE & 3.19606 & 0.08826 \\
\hline LRDE does not Granger Cause LRME & 4.89706 & 0.03811 \\
\hline LRGDP does not Granger Cause LREGS & 4.54040 & 0.04509 \\
\hline LREGS does not Granger Cause LRGDP & 0.59667 & 0.44846 \\
\hline "LRME does not Granger Cause LRI & 4.61814 & 0.04345 \\
\hline LRI does not Granger Cause LRME & 1.26623 & 0.27317 \\
\hline
\end{tabular}

Note: RGDP is log real GDP, LRDE is log real domestic exports, LRI is log real imports, LREGS is log real export of goods and services and LRME is log real manufacturing export.

\subsubsection{Conclusions}

This study examined the causal relationship between exports and economic growth in Jordan during the period 1980-2004. Unidirectional causality from economic growth to exports was found. No causality from exports to economic growth was found in the case of Jordan. Causality from economic growth to exports suggests that policy makers should take into account alternative policies in the future when making decisions regarding accelerating economic growth. Since exports is considered one of the main components of GDP, when taking into account the expenditure approach, direct and indirect impacts can be caused from exports to economic growth. Undoubtedly, depending heavily on export-led growth strategy in order to stimulate and accelerate economic growth in Jordan may be misleading. Moreover, this study supports the findings of Dodaro 1993, Reizman et al 1996, and Abu-Qarn and Abu Bader 2001 are opposite to the common belief that exports promotion is behind the remarkable growth performance in Jordan. 


\subsection{Model Two: The Effects of QIZs on Per Capita Income}

This section evaluates the effects of the QIZs on the per capita income. As mentioned in the previous chapter, the creation of these zones leads to growth effect on the per capita income of local workers. In fact, the creation of QIZs gives the majority of individuals who were unemployed before creation the zones some source of income. Had this not been the case, it would have been difficult for them to obtain any source of income. In order to capture the full gains of creation QIZ on per capita income we constructed the random effects model and the fixed effects model using 'cross-section-time-series' data set. Under this framework different models have been constructed and tested. We start our analysis by using the method of Ordinary Least Square (OLS) analysis. In this model we try to include the main variables that have direct and indirect effects, in order to examine the impact of establishing QIZs on the per capita income. Within this framework, the per capita income is often used as a proxy for describing the level of standard of living. We defined the per capita income as a function of the per capita income for the last year, the income of local employees operating within the zones, the share of QIZs exports to the domestic exports, income inequality measured by gini coefficient, the ratio of working labor in agriculture and a proxy for the QIZ age. It has been assumed that all these coefficients were expected to be positive and to be significantly related to the per capita income. Moreover, we added other variables such as vocational training inside the zones and the technology transfer from the zones to the country and an index for human development index ${ }^{70}$, these variables have been dropped from the model because they prove not to be significant. We transfer all the variables into the real term to avoid the effects of inflation; moreover, the panel data set was organized according to the survival of the companies in the zones, for instance, if the company was established in the year 2000 and continue surviving until the year 2005. We include this company in the dataset for the years from 2000 to 2005. Other companies were treated in the same way. Suppose a company was established in the year 2003, in this case we include it in the data set from the year 2003 to the year 2005. This method allows us to increase the number of observations to 172 and overpass the small number of observations (38 observations).

70 Human Development Index (HDI) is a comparative measure of poverty, literacy, education, life expectancy, childbirth, and other factors. Used often by United Nations for Development Programme (UNDP) to evaluate the degree of development in countries. 


\subsubsection{Model Specifications}

The model used in this section estimates the changes in the income of local employees working inside the zones, the exports of QIZs companies and the age of these companies. Others variables have been added such as the proportion of workers in agriculture sector and income inequality measured by gini coefficient. The model utilizes regression techniques using cross section-time series dataset to capture these effects. In the cross sectional time series data set, each observation is an observation on " $\mathrm{x}$ ", for unit " $\mathrm{i}$ ", at time "t". Thus, the specification of the model to estimate the effects of the QIZs on per capita income can be described as follows:

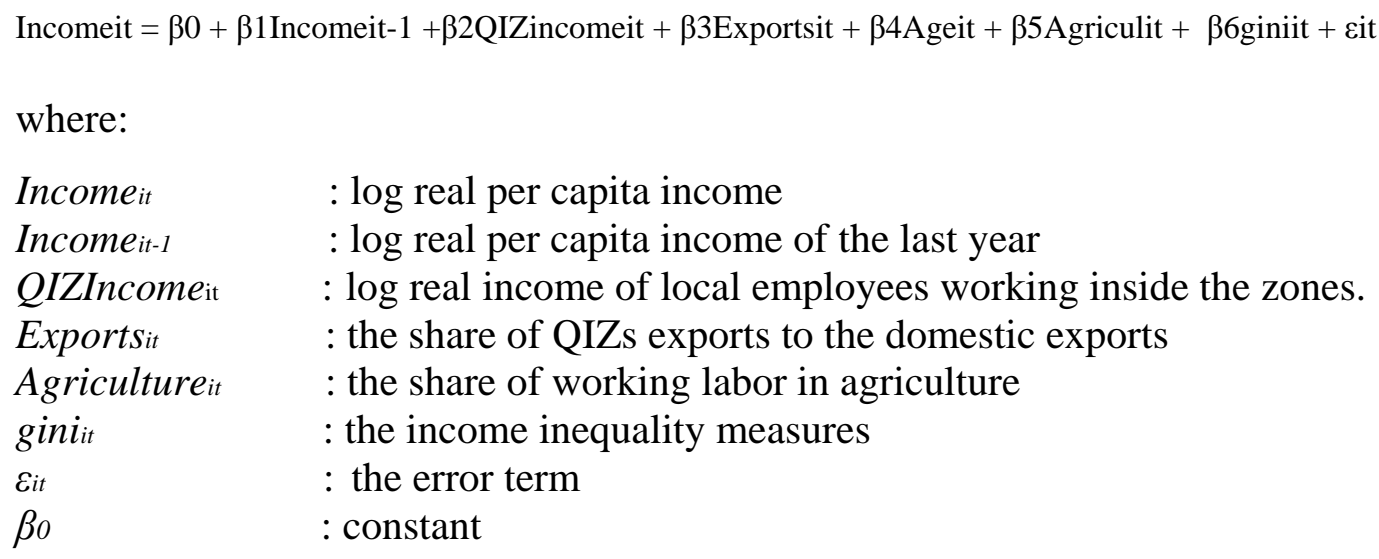

where:

Income $_{i t} \quad$ : log real per capita income

Income $_{i t-1} \quad:$ log real per capita income of the last year

QIZIncome $_{\text {it }} \quad$ : log real income of local employees working inside the zones.

Exportsit : the share of QIZs exports to the domestic exports

Agriculture $_{i t} \quad$ : the share of working labor in agriculture

gini $_{\text {it }} \quad:$ the income inequality measures

Eit $\quad:$ the error term

Bo $\quad$ : constant

Through using equation (10), the effects of the QIZs on per capita income can be captured via the elasticity of $\beta_{1}, \beta_{2}, \beta_{3}, \beta_{4}, \beta_{5}$ and $\beta_{6}$. Following is the regression outputs as well as the analysis of the main results.

Equation 10 is estimated using both the fixed effect and random effect models. The fixed effect model is to be used if one wants to control for the omitted variables, which vary from one company to the next but do not change over time. It allows one to use the changes in the variables over time to estimate the effects of the independent variables on the dependent variable and it is the main technique that used for analysis of such data (DSS, 2006). The fixed effects model can be estimated according to the following equation:

$\mathrm{Y}_{\mathrm{it}}=\beta_{0}+\beta_{1} \mathrm{x}_{1 \mathrm{it}}+\beta_{2} \mathrm{x}_{2 \mathrm{it}}+\ldots+\beta_{\mathrm{k}} \mathrm{x}_{\mathrm{kit}}+\mathrm{a}_{\mathrm{i}}+\mathrm{u}_{\mathrm{it}}$ 
where $a_{i}$ represents an unobserved heterogeneity that is stable (or fixed) over time. While in the random effects model, we assume that the unobserved effect $a_{i}$ is uncorrelated with each explanatory variable and according to the following assumption.

$\operatorname{Cov}\left(\mathrm{x}_{\mathrm{kit}}, \mathrm{a}_{\mathrm{i}}\right)=0$ for each time period $\mathrm{t}$ and variable $1 \ldots \mathrm{k}$

The random effects model is sometimes described as a regression with a random constant term. In other words, it is assumed that the intercept is a random outcome variable that is a function of a mean value plus a random error. The error term is formed as follows:

$$
\mathrm{v}_{\mathrm{it}}=\mathrm{a}_{\mathrm{i}}+\mathrm{u}_{\mathrm{it}}
$$

And the random effects model is estimated according to the following equation:

$\mathrm{Y}_{\mathrm{it}}=\beta_{0}+\beta_{1} \mathrm{x}_{1 \mathrm{it}}+\beta_{2} \mathrm{X}_{2 \mathrm{it}}+\ldots+\beta_{\mathrm{k}} \mathrm{x}_{\mathrm{kit}}+\mathrm{v}_{\mathrm{it}}$

However, when the unobserved effects $\left(\mathrm{a}_{\mathrm{i}}\right)$ are large and important, the random effects estimates will be similar to the fixed effects model. And when the unobserved effects are unimportant (relative to the variance of $\mathrm{u}_{\mathrm{it}}$ ), the random effects estimates will be closer to a pooled OLS model. Moreover, the random effects estimates are calculated from differences within each company as well as across time, while the fixed effects estimates vary across individual companies and are constant over time.

\subsubsection{Model Results}

Using the statistic data analysis software 'Stata', and the Ordinary Least Squares (OLS) method we estimate the coefficients, which have been assumed to have effects on the per capita income. The results of the model show that all the relations, which have been used in the model, are statistically highly significant at the 1 percent level. Table 6.5 introduces the main results of the OLS model, the fixed effects model as well as the random effects model. 
Table 6.5: Regression of Per Capita Income

\begin{tabular}{|c|c|c|c|c|}
\hline Independent Variables & OLS & Fixed Effects & Random Effects & Between Effects \\
\hline constant & 1.913 & 1.594 & 1.912 & 3.353 \\
\hline t. value & 3.7 & 2.89 & 3.7 & 2.52 \\
\hline Std. Err. & 0.5164 & 0.5522 & 0.5164 & 1.33268 \\
\hline per capita income-1 & 0.204 & 0.197 & 0.204 & 0.179 \\
\hline t. value & 5.92 & 5.36 & 5.92 & 2.27 \\
\hline Std. Err. & 0.03439 & 0.03672 & 0.0015 & 0.0789513 \\
\hline export & 0.0047 & 0.0050 & 0.0047 & 0.0023 \\
\hline t. value & 15.06 & 15.01 & 15.06 & 2.68 \\
\hline Std. Err. & 0.000315 & 0.00033 & 0.000315 & 0.0008659 \\
\hline local income & -0.000000015 & $-1.35 e-08$ & -0.000000015 & $-3.14 e-08$ \\
\hline t. value & -3.21 & -2.72 & -3.21 & -2.66 \\
\hline Std. Err. & 4.66 & $4.95 e-09$ & $4.66 e-09$ & $1.18 e-08$ \\
\hline Gini & -5.009 & -5.463 & -5.009 & -3.557 \\
\hline t. value & -6.9 & -6.93 & -6.9 & -2.10 \\
\hline Std. Err. & 0.7257 & 0.7889 & 0.7257 & 1.696785 \\
\hline Agriculture & -0.012 & -0.011 & -0.012 & -0.0319 \\
\hline t. value & -3.07 & 0.005 & -3.21 & -2.52 \\
\hline Std. Err. & 0.0038 & 0.0038 & 0.0038 & 0.0127044 \\
\hline age & 0.016 & 0.014 & 0.016 & 0.034 \\
\hline t. value & 10.13 & 8.46 & 10.13 & 7.28 \\
\hline Std. Err. & 0.0343 & 0.0367 & 0.0016 & 0.0046 \\
\hline \multicolumn{5}{|l|}{ R-squared } \\
\hline Overall & 0.8659 & 0.8643 & 0.8659 & 0.7886 \\
\hline Between & - & 0.8501 & 0.8629 & 0.9047 \\
\hline Within & - & 0.8784 & 0.8767 & 0.7743 \\
\hline No. of Observations & 170 & 170 & 170 & 170 \\
\hline \multicolumn{5}{|c|}{ Breusch and Pagan Lagrangian multiplier test } \\
\hline $\begin{array}{l}\text { Null Hypotheses: } \\
\text { Calculated chi }{ }^{2}(1)= \\
\text { Prob }>\text { chi-square = }\end{array}$ & $\begin{array}{l}\operatorname{Var}(\mathrm{u})=0 \\
0.57 \\
0.4509\end{array}$ & & & \\
\hline \multicolumn{5}{|l|}{ Hausman test } \\
\hline Null Hypotheses: & \multicolumn{4}{|c|}{ difference in coefficients not systematic } \\
\hline Calculated chi ${ }^{2}(5)$ & 34.66 & & & \\
\hline Prop $>$ chi $^{2}$ & 0.000 & & & \\
\hline
\end{tabular}

Note: Dependent variable is the real per capita income. All variables are significant at 1 percent level.

The results from table 6.5 show that there are not a large differences between both of the fixed and random effects models. In order to choose which model is more consistent among the two models we ran a Hausman specification test (1978). The Hausman test checks the more efficient model against the less efficient one. According to the assumption of Hausman test, the fixed effects model is always consistent but is not efficient, while the random effects model is always efficient but inconsistent. The result of the Hausman test indicates the acceptance of the fixed effects model, because given 5 degrees of freedom, the critical value of chi-squared at the 0.1 percent level is 15.09 , so we can conclude with confidence that a fixed effects estimation should be used, and furthermore, the use of the random effects model can be rejected as efficient.

Choosing the fixed effects model allows for the observation of the omitted variable bias, when these variables vary across companies and are constant over time. Moreover, the 
fixed effects model can explain the variation within each time period, and at the same time, ignoring the variation across time.

The results of equation 10 are reported in table 6.5, according to the OLS regression, for both the results of the fixed effects and the random effects models. Notably, the estimation based on the random effects model and the OLS are similar. While the estimation of the random effects model and the fixed effects model are quite close to each other. The overall estimated coefficients of the model prove to be statistically significant at 1 percent level. Furthermore, the R-squared statistics is 0.88 , which implies that 88 percent of the changes in the per capita income are related to the variables included in the model. When analyzing the results of the estimation of the fixed effects models, omitted variables bias can be observed from the regression. This is because many factors affect the per capita income, including: workers productivity, number of population and the increase in the Gross Domestic Product (GDP). All of these factors may be correlated with the per capita income, and this could lead to omitted variables bias.

The analysis of the fixed effects model shows that the effects of QIZs have a positive impact on the per capita income, as indicated by both the age of the zones, measured in years, and the manufacturing exports from the zones. The age-correlation of the QIZ is positive and significantly related to the per capita GDP at 1 percent level. The positive impact of age within zones on the per capita income leads to 1.4 percent increase in the per capita income. While the effects of exports from the QIZ participate with around 0.5 percent on the per capita income, at 1 percent level of significant. Contrary to the expectations, the income of workers in the QIZs turned out to be a significant factor. The model shows a slight negative effect of the income of local employees on the per capita income by -0.0000014 at 1 percent level. This surprising result has a few possible reasons: 1) the low wages offered to local employees, 2) The instability of local employees to retain working in the zones for long time, and 3) the high turnover among local employees. Nevertheless, the QIZs help to create job opportunities for unemployed persons and allow one to obtain a source of income. Consistent with Forbes (2000) and Sinclair (2001) the model shows negative relation between income inequality measured by gini coefficient and the per capita income at the 1 percent level of significance. According to Sinclair, the level of significance is based on which definition of income 
inequality is used. Kuznets (1955) on the other hand, had a different argument; his hypothesis stipulates that at low levels of per capita income, inequality increases with rising per capita income and decreases only in the later stages of development, thus resulting in an inverted U-shaped relationship between per capita income and income inequality. This hypothesis is based on a model where individuals migrate from a lowwage rural sector (for example the agriculture sector), with little income inequality, to an urban sector (manufacturing sector) characterized by high income inequality and high average income. Nevertheless, Kuznets hypothesis has been built upon different circumstances and might not be able to describe the relation between the income inequality and the per capita income. Other empirical studies carried out by Deiningge and Squire (1997) confirm Kuznet's hypothesis, but at the same time they found that the relation is fairly weak.

The model shows also that when a country established a zone, a portion of the labor force that works in the agricultural sector is convexly related to the per capita income. The vintage of these zones are shown to be negatively related to the share of the labor force that works in the agricultural sector. This is because through establishment of zones, labor moves out of the seasonal agricultural sector, which results in a positive economic growth impact on the per capita income. According to the UNDP report there were a lot of workers, particularly female, who left the work in the seasonal agricultural sector and choose to work in the QIZs companies, and these companies can, therefore, be considered as a catalyst for economic growth. The overall effect of establishing QIZs is about $0.8 \%$ increase in the per capita income, when accounting for all the variation across companies in the zones that are assumed to have effects on the per capita income.

\subsection{Model Three: The effect of QIZs on Unemployment}

In this section we will try to examine the effects of creating QIZs on the unemployment rate a given country. Although these zones help to create job for unemployed individuals, their impact on the unemployment rate is minor. Given that the number of local employees consists roughly 0.8 percent of the total labor force in the country, this number is not very impressive. In order to clarify the impact of QIZs on the unemployment, however, we should asked different questions: 1) whether or not local employees were calculated as unemployed before starting work in the QIZs, 2) whether or not they were 
considered unemployed and included in the unemployment rate. If they are not included with the unemployed, then the influence of the QIZs on the employment would lead to biased results. According to the World Bank report, most local workers in the zones were in transit from inactivity to employment ${ }^{71}$. This means that most of the job opportunities created in the zones were given to those who previously were not actively seeking a job. This is because those local employees not considered in the calculation of unemployment figures, because they were considered to be inactive, and in this case the overall effects on unemployment should be minimal. Figure 6.1 depicts the growth trend in unemployment rates, labor force, and local employees operating within the QIZs. It is shows that there is a steady growth in the labor force, and at the same time, when there is a decrease in the growth of local employees in the QIZs, there is also a decrease in the growth of the unemployment rate. This indicates that in spite of the numerous jobs created from the QIZs, only inactive persons benefit from these zones. Contrary to the expectation, the effect on unemployment is minor and is not great as previously expected.

Figure 6.1: Growth Rate of Unemployment, Labor force

\& Local Employees in QIZs

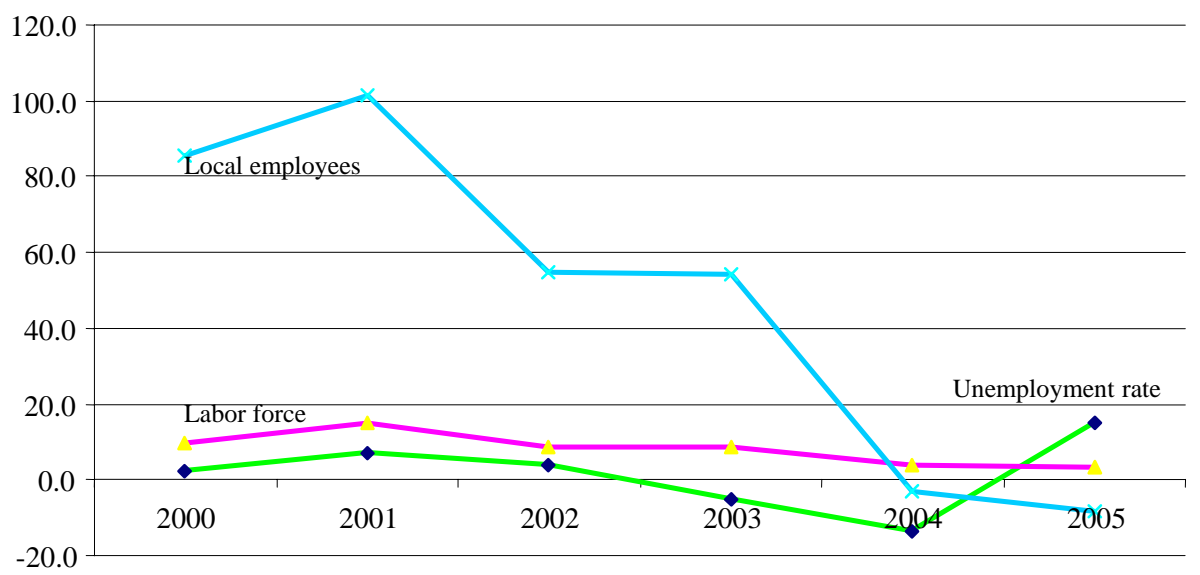

Sources: World Bank, and author calculation

Additionally, we will try in this section to make an in-depth analysis using the same methodology of the prior section (section 6.5). For this, both random and fixed effects models have been used to measure the potential impacts on the unemployment. Empirically, the QIZs effect on unemployment can be estimated according to the following equation:

71 World Bank publication, the role of exports and qualified industrial zones in economic growth, fourth quarter 2004 
InEmployit $=\beta 0+\beta 1$ Localemployeesit $+\beta 2$ Ageit $+\beta 3$ Agrit $+\beta 4$ giniit $+\beta 5$ manufit $+\varepsilon$ it

where:

InEmployit : : the log annual changes of unemployment rate

Localemployeesit : the log annual changes of local employees working inside the zones.

Ageit $\quad:$ the age of the zones measured by number of years

Agrit : the annual changes in the labor force in agriculture sector

Giniit : the inequality income measured by gini coefficient

Manufit : : the log share of manufacturing to the GDP

sit $\quad:$ the error term

$\beta 0 \quad$ : constant

In this model we estimate the coefficients $\beta 1, \beta 2, \beta 3, \beta 4$, and $\beta 5$ that have been assumed to have an effect on the unemployment. The results of the model show that all the relations included in the model are statistically highly significant at the 1 percent level. Table 6.6 introduces the main results of the OLS model, the fixed effects model as well as the random effects model.

Table 6.6: Regression of Unemployment

\begin{tabular}{|c|c|c|c|}
\hline Independent Variables & OLS & Fixed Effects & Random Effects \\
\hline constant & -106.38 & -94.34 & -106.3 \\
\hline t. value & -7.47 & -4.89 & -6.93 \\
\hline Std. Err. & 14.620 & 19.28 & 15.3 \\
\hline Agrilabor & -0.0063 & -0.0062 & -0.0063 \\
\hline t. value & -3.61 & -2.87 & -3.61 \\
\hline Std. Err. & 0.0017 & 0.0021 & 0.0017 \\
\hline Localemployees & -0.119 & -0.119 & -0.119 \\
\hline t. value & -16.19 & -13.81 & -16.20 \\
\hline Std. Err. & 0.0073 & 0.0086 & 0.0073 \\
\hline Age & -0.125 & -0.122 & -0.125 \\
\hline t. value & -4.92 & -3.99 & -4.92 \\
\hline Std. Err. & 0.0254 & 0.0306 & 0.025 \\
\hline Sharemanuf & -1.107 & -1.20 & -1.107 \\
\hline t. value & -2.91 & -2.77 & -2.92 \\
\hline Std. Err. & 0.379 & 0.432 & 0.379 \\
\hline gini & 261.9 & 235.5 & 261.7 \\
\hline t. value & 7.17 & 5.16 & 7.17 \\
\hline Std. Err. & 36.52 & 45.60 & 36.5 \\
\hline \multicolumn{4}{|l|}{$R$-squared } \\
\hline Overall & 0.94 & 0.93 & 0.94 \\
\hline Between & - & 0.93 & 0.94 \\
\hline Within & - & 0.93 & 0.93 \\
\hline \multicolumn{4}{|l|}{ No. of Observations } \\
\hline \multicolumn{4}{|c|}{ Breusch and Pagan Lagrangian multiplier test } \\
\hline Null Hypotheses: & $\operatorname{Var}(u)=0$ & & \\
\hline Calculated chi $^{2}(1)=$ & 1.50 & & \\
\hline Prob $>$ chi-square $=$ & 0.22 & & \\
\hline \multicolumn{4}{|l|}{ Hausman test } \\
\hline Null Hypotheses: & \multicolumn{3}{|c|}{ difference in coefficients not systematic } \\
\hline Calculated chi ${ }^{2}(4)$ & 2.69 & & \\
\hline Prop $>$ chi $^{2}$ & 0.44 & & \\
\hline
\end{tabular}


The results of equation (14) were estimated according to the OLS techniques, the fixed effects model and the random effects model. Both Hausman test and Breusch and Pagan Lagrangian multiplier test were applied into the model. The $H_{0}$ hypothesis that there are differences in the coefficients between the random effects model and the fixed effects model was tested using the Hausman test, and put against the alternative hypothesis $\left(\mathrm{H}_{1}\right)$ that there are no differences between the two models. Using the Breusch and Pagan Lagrangian multiplier test we examined for the existence of the random effects. However, the result of Hausman test indicates that with 4 degrees of freedom, the critical value of chi-squared at the 0.1 percent level is 7.77 . This means that we accept the null hypothesis $H_{0}$ that there are indeed differences between the two models, and the random effects model is the efficient model to analyze our results. Moreover, the Breusch and Pagan Lagrangian multiplier test, also accept the null hypothesis $\left(H_{0}\right)$ because the critical value of chi-squared with 1 degree of freedom at 1 percent level is 6.63. As indicated by both tests, by accepting the null hypothesis, we are now able to use the random effects model with great confidence.

The overall estimated coefficients of the model prove to be statistically significant at 1 percent level. Furthermore, the R-squared statistics is 0.94, which implies that 94 percent of the changes in the unemployment rate are in some way related to the variables included in the model. When analyzing the results of the random effects model, we can notice that the correlation between local workers operating in the QIZs and unemployment is negative, this is clear from the numerous jobs created for local employees as a result of establishing these zones. Consistent with the vast majority of literature on export processing zones, one of the most important objectives of many developing countries, when setting up zones, is the generation of employment in order to reduce unemployment rate. The model shows that the zones were capable of reducing unemployment rate by 11.9 percent at 1 percent level of significance. This result is not consistent with the assumption we had previously drawn, that one significant factor is whether or not local employees were calculated as unemployed before starting work in the QIZs. However, the impact of the QIZs in creating jobs for workers is remarkable, and at the same time, there are many more tasks to be done by the government, in order to increase the impacts of these zones in reducing the unemployment rate in the country. 
The government can increase the impact either by substituting local workers in place of foreign workers or by using only local workers in the future. From the other side, the age of the QIZ measured in years shows a negative relation with the unemployment rate as expected and at 1 percent level of significant. The model shows that by increasing the age of companies, operating within the zones, measured by it is capability to survive by one unit will lead to reduce the unemployment rate by 12.5 percent.

Moreover, the model shows that the share of labor force that works in the agricultural sector is positively correlated to the decrease in unemployment rate. However, in spite of this fact, there was a drastic decline in the role of the agriculture sector in the economy. Yet it appears that the agriculture sector still has an effect in reducing the unemployment rate. According to the results demonstrated by the model, increasing the workers in the agriculture sector by 1 percent will help to reduce the unemployment rate with about 0.6 percent at the 1 percent level of significance. The role of manufacturing sector proves also to have a dramatic effect in reducing the unemployment rate. The model shows that by increasing the share of manufacturing to the gross domestic product, there will be a remarkable decrease in the unemployment rate. This is because the role of the manufacturing sector in Jordan still has an impact on unemployment; moreover, the manufacturing sector is considered as a catalyst in creating jobs for local employees.

In addition to the results shown above, the model also shows that there is a positive relation between income inequality and unemployment rate at 1 percent significance level. According to Furman and Stiglitz (1998), there is a relationship between income inequality and the unemployment rate in the long run. They argued that the experience in the United States is consistent with the hypothesis that inequality and unemployment move together. Nevertheless, the result of the model is consistent with Furman and Stiglitz that increasing inequality leads to increase unemployment particularly with unemployed low skilled individuals.

The overall impacts of QIZs on unemployment is, nonetheless, minor because these zones attract inactive workers, 70 percent of these being female. On the other hand, the zones also help to open the door to increase number of foreign workers in the country, and this affects the ability of local unemployed persons to find employment in the future. 


\subsection{Econometric Shortcomings}

In the previous section, we investigated the export-led hypothesis by using standard procedures and without taking into consideration the problems of endogeneity and structural breaks in the time series data. Hence, other problems, such as an omitted variables bias, may exist as well. If these problems are not corrected, the results of the regressions cannot be trusted. Before continuing our analysis, it is important to examine the time series properties of the variables involved in the model in more depth. However, the model we have constructed is likely to suffer from a number of shortcomings, particularly when dealing with time series data.

\subsubsection{Endogeneity:}

The Endogeneity problem usually appears when one of the right hand side variables is determined by the left-hand side variable. It is clear from the model above that we have endogeneity problem because of the relationship between exports and economic growth. The reason for this is that exports are one of the components of the national income accounting identity and thus partly endogenous within the GDP equation. The standard methodology that has been used to solve this problem is to use valid instrument variables that are uncorrelated with the residuals.

Frankel and Roemer (1999) defined the instrument variable as a variable that does not itself belong in the regression, correlated with the explanatory variable, and uncorrelated with the error term ${ }^{72}$. In other words, the instrument variable should be correlated with the independent variable (x) and being not a direct determinant of or less correlated with the dependent variable (y).

The typical method used to test for endogeneity problem is the Durbin-Wu-Hausman (DWH) test. However, if a valid instrument is available, consistent estimates may still be

obtained. After testing different instrumental variables, we found that currency basket shares based on trade weights of Jordan for the European Union, the USA, and the Arab countries are valid instruments to use in our model. However, the result of the DWH test in table 6.7 shows that we can accept the null hypothesis that the regressor is exogenous 
and the model is not biased by the endogeneity problem. We achieved an improvement on the previous models by adding domestic exports as share of the GDP as a new variable. In addition, we take into consideration structural breaks in the time series data, as will be explained in the next section.

Table 6.7: Durbin-Wu-Hausman (DWH) test results

\begin{tabular}{|l|c|c|c||}
\hline Variable & Coefficient & t. statistics & P. value \\
\hline LDE & 0.542 & 5.2 & 0.00 \\
\hline LRI & 0.247 & 2.8 & 0.01 \\
\hline LME & 0.059 & 5.7 & 0.00 \\
\hline DE/GDP & -0.035 & -4.8 & 0.00 \\
\hline dummy & 0.027 & 2.2 & 0.03 \\
\hline constant & 3.262 & 0.258 & 0.00 \\
\hline Tests of endogeneity of: LDE & \multicolumn{4}{l||}{$\begin{array}{l}\text { H0: Regressor is exogenous } \\
\text { Wu-Hausman F test: } \\
\text { Durbin-Wu-Hausman chi-sq test: 3.01230 F(1,18) P-value }=0.09972 \\
\text { Note: LRGDP is log real GDP, LRDE is log real domestic exports, LRI is log real imports,DE/GDP is }\end{array}$} \\
Domestic as share of GDP, LRME is log real manufacturing export, and dummy variable for the \\
structural breaks in 1990 and 1999. LGDP is the dependent variable.
\end{tabular}

\subsubsection{Structural Breaks:}

It is clear from the unit root test that the problem of structural changes can be found in the time series data because the Jordanian economy is vulnerable to external shocks and regional instability. For instance, during the last decade, the economy faced several extreme shocks (e.g. the financial crisis in 1989, the Gulf war in 1990-1991, the death of King Hussein in 1999, and the Iraqi war in 2003).

However, the economy has managed to successfully survive these shocks. Therefore, in order to determine the time series properties of the variables, we have carried out the standard Augmented Dickey Fuller (ADF) test as well as Philips-Perron unit root test and Zivot-Andrews unit root test to allow for structural breaks in the series.

One problem we might face is that the Philips-Perron procedure allows only for one possible break point for any single series. To consider the possibility that two break points occurring over the studied period, we apply the Clemente-Montanes-Reyes (CMR) 
unit root test with two structural breaks ${ }^{73}$. The CMR test also allows for two structural breaks in the mean of the variable. There are two versions of the test: the first one is the additive outliers model which seeks to capture a sudden change in a series, and the second one is the innovational outliers model which allows for a gradual shift in the mean of the series. The test results reported in this study are for the innovational outliers model. The main result of the tests is that they identifying the true order of integration for each variable.

We note that the break detected by the test roughly corresponds to the timing of the financial crisis in the end of 1989, the timing of the 1991 Gulf war and the death of King Hussein in 1999. Table 6.8 depicts the main break points in the Jordanian economy during the period 1980-2004.

Table 6.8: Unit Root Test Results for the Period between 1980 and 2004

\begin{tabular}{|l|c|c|c|c||}
\hline \multirow{2}{*}{} & & & \multicolumn{2}{c|}{$\begin{array}{c}\text { Clemente-Montanes-Reyes test: } \\
\text { single and two structural breaks }\end{array}$} \\
\cline { 3 - 5 } & $\begin{array}{c}\text { ADF test } \\
\text { no breaks }\end{array}$ & $\begin{array}{c}\text { Zivot-Andrews } \\
\text { Single break }\end{array}$ & $\begin{array}{c}\text { Two structural } \\
\text { breaks } \\
\text { in mean }\end{array}$ & $\begin{array}{c}\text { Single } \\
\text { structural break } \\
\text { in mean }\end{array}$ \\
\hline LRGDP & $I(1)$ & $I(0) 1989$ & $I(0) 1990 / 99$ & $I(0) 1990$ \\
\hline LDE & $I(1)$ & $I(0) 1991$ & $I(0) 1982 / 99$ & $I(0) 1999$ \\
\hline LRI & $I(1)$ & $I(0) 1992$ & $I(0) 1990 / 98$ & $I(0) 1990$ \\
\hline LME & $I(1)$ & $I(2) 2000$ & $I(1) 1990 / 99$ & $I(0) 1999$ \\
\hline DE/GDP & $I(1)$ & $I(0) 1991$ & $I(0) 1985 / 99$ & $I(0) 1999$ \\
\hline \hline
\end{tabular}

Note: LRGDP is log real GDP, LRDE is log real domestic exports, LRI is log real imports,DE/GDP is Domestic as share of GDP and LRME is log real manufacturing export.

As can be seen from table 6.8, the results of the unit root tests show that it is difficult to capture the true order of integration of the individual series. The low power of unit root tests, the sensitivity of unit root tests to lag length selection, and the possible presence of one or more structural breaks in mean, trend, or both, introduces uncertainty as to the true order of integration of the individual series ${ }^{74}$.

We tried to make other econometric tests to ensure the consistency of our data, in addition we include domestic exports as share of GDP as a new variable. However, we got the same results as in the ADF test when we use Phillips-Perron test for unit root.

73 Baum, C. F. (2001). Stata: The language of choice for time series analysis? The Stata Journal, November, pp 1 -16.

74 Shanks, S. and Zheng S. (2006). Econometric Modelling of R\&D and Australia’s Productivity, Staff Working Paper, Productivity Commission, Australian Government, April. 
Table 6.9 shows that we can reject the null hypothesis that the first differences time series are non-stationary. However, the results of these tests indicate that all time series data are non-stationary in levels, but stationary in their first differences.

Table 6.9: Phillips-Perron test for unit root in first differences series

\begin{tabular}{||l|c|c|c|c|c||}
\hline \multirow{2}{*}{ Variables } & \multirow{2}{*}{ T. Statistics } & \multicolumn{3}{|c||}{ Critical Value } & \multirow{2}{*}{ P. Value } \\
\cline { 3 - 6 } & & $\mathbf{1 \%}$ & $\mathbf{5 \%}$ & $\mathbf{1 0 \%}$ & \\
\hline L RGDP & -4.45 & -3.75 & -2.99 & -2.64 & 0.002 \\
\hline L RI & -4.63 & -3.75 & -2.99 & -2.638 & 0.0013 \\
\hline L RME & -5.19 & -3.75 & -2.99 & -2.638 & 0.0004 \\
\hline LRDE & -5.175 & -3.75 & -2.99 & -2.638 & 0.0004 \\
\hline DE/GDP & -3.50 & -3.75 & -2.99 & -2.638 & 0.017 \\
\hline
\end{tabular}

Note: LRGDP is log real GDP, LRDE is log real domestic exports, LRI is log real imports, and LRME is log real manufacturing export.

According to the results from table 6.10, we can reject the unit root null hypothesis if the value of $\mathrm{t}$ ratio is smaller than the critical values provided by Perron and Vogelsang (1992). According to the result of the CMR unit root test in table 6.10, the value of $t$ ratio is less than the critical values provided by Perron and Vogelsang. Thus, the results derived from the ADF and Perron-Phillips test are placed in doubt, as this is evidence that these models excluding structural breaks are clearly misspecified due to the omission of relevant explanatory variables.

Despite the structural breaks in the years 1990 and 1999, we are unable to reject the null hypothesis of a unit root in this series. To solve this problem we used dummy variables for the years 1990 and 1999. In order to be more specific, we took into consideration that the effects of the economic shocks might last for more than one year. Hence, If all variables are found to be $I(1)$, the second step is to test for the existence of a cointegration relationship between them. 
Table 6.10: Clemente-Montañés-Reyes Unit Root Test

\begin{tabular}{|c|c|c|c|c|}
\hline L RGDP & \multicolumn{4}{|c|}{ optimal breakpoints : 1990,1999} \\
\hline AR( 0$)$ & du1 & du2 & (rho - 1) & const \\
\hline Coefficients: & 0.1176 & 0.11813 & -0.38214 & 3.13636 \\
\hline t-statistics: & 4.212 & 3.288 & -4.189 & \\
\hline P-values: & 0.001 & 0.004 & & \\
\hline critical value (5\%) & & & -5.49 & \\
\hline L RDE & \multicolumn{4}{|c|}{ optimal breakpoints : 1982,1999} \\
\hline Coefficients: & 0.16292 & 0.27842 & -0.27481 & 1.68621 \\
\hline t-statistics: & 1.865 & 3.827 & -3.473 & \\
\hline P-values: & 0.078 & 0.001 & & \\
\hline critical value (5\%) & & & -5.49 & \\
\hline L RI & \multicolumn{4}{|c|}{ optimal breakpoints : 1990, 1998} \\
\hline Coefficients: & 0.25388 & 0.187 & -0.70953 & 5.26381 \\
\hline t-statistics: & 5.091 & 4.196 & -5.957 & \\
\hline P-values: & 0.00 & 0.001 & & \\
\hline critical value (5\%) & & & -5.49 & \\
\hline L REGS & \multicolumn{4}{|c|}{ optimal breakpoints : 1985,2000} \\
\hline Coefficients: & 0.20347 & 0.18026 & -0.20918 & 1.44802 \\
\hline t-statistics: & 3.489 & 3.298 & -4.775 & \\
\hline P-values: & 0.003 & 0.004 & & \\
\hline critical value (5\%) & & & -5.49 & \\
\hline L RME & \multicolumn{4}{|c|}{ optimal breakpoints : 1990,1999} \\
\hline Coefficients: & 0.32927 & 1.11798 & 0.03272 & -0.19287 \\
\hline t-statistics: & 3.019 & 4.523 & 0.151 & \\
\hline P-values: & 0.013 & 0.001 & & \\
\hline critical value (5\%) & & & -5.49 & \\
\hline
\end{tabular}

Note: LRGDP is log real GDP, LRDE is log real domestic exports, LRI is log real imports,DE/GDP is Domestic as share of GDP and LRME is log real manufacturing export.

When we applied the Johansen cointegration test again, we found similar results with the previous test in table 6.3, therefore we reject the hypothesis that there are cointegration between domestic exports and economic growth, since both the null that $(r=0,1,2,3,4)$ are rejected at 1 percent significance level as indicated in table 6.11.

Table 6.11: Johansen Cointegration Test (new)

\begin{tabular}{|l|c|c|c|c|c|c|c|}
\hline $\begin{array}{c}\text { Cointegratio } \\
\text { n Vectors } \\
\text { r }\end{array}$ & $\begin{array}{c}\text { Eigen } \\
\text { value }\end{array}$ & $\begin{array}{c}\text { Trace } \\
\text { Statistic }\end{array}$ & $\begin{array}{c}\mathbf{5 \%} \\
\text { Critical } \\
\text { Value }\end{array}$ & $\begin{array}{c}\mathbf{1 \%} \\
\text { Critical } \\
\text { Value }\end{array}$ & $\begin{array}{c}\text { Max-Eigen } \\
\text { Statistic }\end{array}$ & $\begin{array}{c}\mathbf{5 \%} \\
\text { Critical } \\
\text { Value }\end{array}$ & $\begin{array}{c}\mathbf{1 \%} \\
\text { Critical } \\
\text { Value }\end{array}$ \\
\hline $\mathrm{r}=0^{\star}$ & 0.735433 & 69.49163 & 68.52 & 76.07 & 30.58216 & 33.46 & 38.77 \\
\hline $\mathrm{r}=1$ & 0.535465 & 38.90947 & 47.21 & 54.46 & 17.63452 & 27.07 & 32.24 \\
\hline $\mathrm{r}=2$ & 0.436801 & 21.27495 & 29.68 & 35.65 & 13.20482 & 20.97 & 25.52 \\
\hline $\mathrm{r}=3$ & 0.287865 & 8.070128 & 15.41 & 20.04 & 7.808227 & 14.07 & 18.63 \\
\hline $\mathrm{r}=4$ & 0.011322 & 0.261901 & 3.76 & 6.65 & 0.261901 & 3.76 & 6.65 \\
\hline
\end{tabular}

Note: $*(* *)$ denotes rejection of the hypothesis at the $5 \%(1 \%)$ level. Trace test indicates 1 cointegrating equation(s) at the $5 \%$ level and indicates no cointegration at the $1 \%$ level. Max-eigenvalue test indicates no cointegration at both $5 \%$ and $1 \%$ levels.

The last step in our analysis is to apply the Granger Causality analysis. Table 6.12 shows the main results of Granger Causality tests. Therefore, we can conclude our results by 
saying that the causality direction is from economic growth to exports and similar to our previous results. We found that the direction of causality is from imports to exports and at the same time, there is causality between economic growth and imports. The causality direction going from manufacturing exports to imports indicates the role of manufacturing in generating imports activity. This is because of the high dependency of Jordanian exports on imported raw materials, intermediate goods, and capital machinery.

Table 6.12: Granger Causality Test Results (new)

\begin{tabular}{|l|c|c|}
\hline Null Hypothesis & F-Statistics & Probability \\
\hline LRGDP does not Granger Cause LIMP & 3.21063 & 0.08758 \\
\hline LIMP does not Granger Cause LRGDP & $4.2 \mathrm{E}-07$ & 0.99949 \\
\hline LRME does not Granger Cause LIMP & 4.28254 & 0.05103 \\
\hline LIMP does not Granger Cause LRME & 1.27077 & 0.27234 \\
\hline DEGDP does not Granger Cause LIMP & 0.81096 & 0.37805 \\
\hline LIMP does not Granger Cause DEGDP & 6.20879 & 0.02115 \\
\hline LRME does not Granger Cause LRGDP & 1.30760 & 0.26570 \\
\hline LRGDP does not Granger Cause LRME & 2.57576 & 0.12345 \\
\hline DEGDP does not Granger Cause LRGDP & 0.08775 & 0.76997 \\
\hline LRGDP does not Granger Cause DEGDP & 6.06667 & 0.02250 \\
\hline DEGDP does not Granger Cause LRME & 0.03132 & 0.86123 \\
\hline LRME does not Granger Cause DEGDP & 2.67737 & 0.11668 \\
\hline
\end{tabular}

Note: LRGDP is log real GDP, LRDE is log real domestic exports, LRI is log real imports, LREGS is log real export of goods and services, LRME is log real manufacturing export, DEGDP is domestic export as share of GDPs and MEGDP is manufacturing export as share of GDP.

\subsubsection{Small-sample size:}

Econometric tests under small samples (limited observations) often have very low significance. However, we are aware that the models suffer from small sample size and we suggest that the results yielded by the models need to be considered with caution.

Future research on the relationship between QIZs companies and the welfare of the host country - both at the company and industry level - need to address some measurement issues that affect the data quality. Extending cross section, time series data to increase the number of observations would be helpful. Construction of more specific company-level and industry-level models may also be needed. In the presence of the small sample size, we suggest to use panel data analysis in the future because it is more dynamic. 


\subsection{Conclusion}

This chapter investigates the main effects of establishing the QIZs on the economy by using statistical analysis. Different models have been constructed and used in this chapter to examine the relationship between the QIZs, the economic growth, the per capita income and the unemployment. Granger causality analysis has been used to examine the causal relationship between exports and economic growth. The fixed effects model and the random effects model were used to assess the effects of QIZs on per capita income and unemployment. However, unidirectional causality from economic growth to exports was found. No causality from exports to economic growth was found in the case of Jordan, Causality from economic growth to export suggests that policy makers should take into account alternative policies in the future when making decisions regarding accelerating economic growth. The results of the fixed and random effects models seem to be more similar to the results obtained from the qualitative analysis in chapter five. Both models show weakness effects of the QIZs on per capita income and unemployment. For instance, the model shows a slight negative effect of the income of local employees on the per capita income by -0.0000014 at 1 percent level. This surprising result has a few possible reasons: 1) the low wages offered to local employees, 2) The instability of local employees to retain working in the zones for long time, and 3) the high turnover among local employees. Nevertheless, the QIZs help to create job opportunities for unemployed persons and allow one to obtain a source of income. Regarding unemployment, the overall impacts of QIZs on unemployment is, nonetheless, minor because these zones attract inactive workers, 70 percent of these being female. On the other hand, the zones also help to open the door to increase number of foreign workers in the country, and this affects the ability of local unemployed persons to find employment in the future.

The results of the quantative analysis in this thesis demonstrate that in the absence of strong evidence that the data are sufficient and consistent, the results of the econometric models must be handled with caution. 


\section{CHAPTER 7}

\section{POLITICAL ASSESSMENT AND \\ PRUDENT PLANNING}

\subsection{Introduction}

This section deals with the assessment of the political situation and the potential prudent planning for future application of the Qualifying Industrial Zones (QIZs). It explains in details the experience of establishing these zones on the country from economic point of view in the previous chapters as well as from political point of view in this chapter. Moreover, this section will try to answer some question related to the future application of this kind of schemes on the host country. For example, what was the expectation when Jordan established these zones? Did establishing these zones meet Jordan expectations? What were the advantages and disadvantages of these zones on the country, if there are any? What would have happened if Jordan did not establish these zones? Depending on the key results of chapter five, this chapter will provide more in depth analysis to the schemes, and its potential answers.

To date, there have been few assessments of the impact of the QIZs on the Jordanian economy. This chapter aims at filling this gap by analyzing the potential impact of these zones that may have had over the past years on the national economy, and the region as a whole. Less than ten years have passed since the establishment of the first QIZ in Jordan. The future of QIZs is less likely to be in jeopardy, since there are a lot of companies still operating in the zones for a long period. In addition a number of local companies is likely to increase by time when they accumulate the needed experience. 


\subsection{Overview of the Current Situation}

The agreement on QIZs was signed first between the USA, Jordan and Israel in 1997 during Doha summit. The main aim of this agreement was to strengthen peace and stability in the region and to use QIZs as a model for future regional cooperation in order to introduce Israel through Jordan to other Arab countries. Less than ten years have passed since the establishment of the first QIZ in Jordan and the success of QIZs is still striving, since most companies in the QIZs specialized in exports of light manufactured products, principally textiles and manufactured garments. Economically, data about the QIZs are quite impressive and look promising. Between 1999 and 2004 exports jumped from US\$ 2.4 million to US\$ 1.1 billion, while employment reached more than thirty thousand employees. Politically, however the situation between Israel and Jordan is still unstable. No monumental changes have been made towards normalization between the two countries ${ }^{75}$. Relations between Israel and Jordan mainly take place through highly official delegations and business deals to cover the required inputs as mentioned in the QIZs agreement. Due to the fact that most of the investors in the QIZs are from Asian countries, neither interaction nor cooperation efforts have been made until now. According to article II of the QIZs agreement between Jordan, Israel and the USA, the primary purposes of the legislation and proclamation is to encourage economic cooperation in the region, through creating joint ventures between Jordanian and Israeli businesses. According to Hani Mulki, former Minister of Industry and Trade in Jordan, QIZs are a privilege to Jordan, with the USA helping to strengthen peace and stability in the region and to use QIZs as a model for future regional cooperation ${ }^{76}$. Another declaration by Zaid Marar, spokesperson of Silver Planet Company in the Al-Tajamout QIZ says "The QIZs are very important to the American government. Jordan is a buffer state between Israel and its hostile Arab neighbors so it is very important that Jordan's economy be linked with the USA economy"77. From Israel and the USA point of view, Jordan is a bridge to the Arab world, and views the prospect of close economic and trade

\footnotetext{
${ }^{75}$ Jordan Country Profile,2005, Oxford Business Group,. Also can be found in http://www.oxfordbusinessgroup.com

${ }^{76}$ Ghalia Alul Jordan Times , December 13, 1997

${ }^{77}$ Aaron Glantz Jordan's Sweatshops, 2003: The Carrot or the Stick of US Policy? Global Policy Forum CorpWatch February 26,
} 
ties with an Arab state as an important step towards easing its regional isolation. However, the political goals have not been achieved as expected and Israel still remains a strange entity in the Arab world.

Nevertheless, QIZs prove to be more promising in achieving some of the economic goals of the country in comparison with achieving the political one. According to the international trade theories, trade between countries leads to economic integration, boosts economic growth and alleviates poverty and may in the end also strengthen political cooperation between countries. So far, a closer cooperation has only been achieved on the economic side. There is an important question that should be asked, whether it is enhancing the economic situation should be considered first in order to enhance the political situation, or is enhancing the political situation considered the priority, in a hope that economic cooperation will follow afterwards? Latest data show the tremendous increase in trade between Jordan and Israel following the signing of the peace treaty in 1994 and the QIZs agreement in 1997. Table 7.1 presents the performance of the trade balance between Jordan and Israel.

Table 7.1: External Trade of Jordan with Israel in Thousands of US\$

\begin{tabular}{|c|c|c|c|}
\hline Year & $\begin{array}{c}\text { Import } \\
\text { (C.I.F.) }\end{array}$ & $\begin{array}{c}\text { Domestic Export } \\
\text { (F.O.B.) }\end{array}$ & Trade Balance \\
\hline $\mathbf{1 9 9 6}$ & 2.912 & 6.045 & 3.133 \\
\hline $\mathbf{1 9 9 7}$ & 13.685 & 24.904 & 11.219 \\
\hline $\mathbf{1 9 9 8}$ & 22.738 & 34.259 & 11.522 \\
\hline $\mathbf{1 9 9 9}$ & 29.094 & 52.910 & 23.815 \\
\hline $\mathbf{2 0 0 0}$ & 70.736 & 78.071 & -3.335 \\
\hline $\mathbf{2 0 0 1}$ & 111.010 & 102.899 & -110 \\
\hline $\mathbf{2 0 0 2}$ & 125.965 & 123.049 & -37.166 \\
\hline $\mathbf{2 0 0 3}$ & 133.931 & 96.765 & -61.197 \\
\hline $\mathbf{2 0 0 4}$ & 164.920 & 103.723 & \\
\hline
\end{tabular}

Source: Department of Statistics

Table 7.1 shows that the trade performance between Israel and Jordan was in favor to Jordan until the year 2000, though it was at a low level compared to trade with other countries. After QIZs became more effective and spread in the country, the trade balance turned in favor of Israel. Moreover, in the year 1996 exports to Israel totaled around US\$ 6 Million and jumped to about US\$ 103 Million in the year 2004, while imports from 
Israel stood at US\$ 3 Million in 1996 and soared to around US\$ 165 Million in the year 2004. The overall balance of trade between Jordan and Israel, with the exception of the years before 2000, has been constantly in favor of Israel. Nevertheless, QIZs seem to be the source for the achieved economic growth in Jordan during the last years as recorded in table 7.2. Some observers adopt a pessimistic view regarding these zones. According to Benjamin Orbach from the Daily Star, the large part of the zones' success is attributed to investors from Asian countries who have exploited these zones as a temporary back door opportunity to benefit from the quota and duty-free agreements to export to the USA market. Moreover, these companies are not concerned with the development of local industries or local labor force. Pete Moore from the Middle East Report (MERIP) says that the much touted peace dividend such as the QIZs agreement has turned out to be bait for ordinary Jordanians. According to Moore, this is because the unemployment remains high and per capita income has essentially remained locked at its 1984 level. Moreover, manufacturers struggle to ensure that Israeli contributions meet the minimum of (7- 8) percent $^{78}$. Nevertheless, investors prefer trading with the USA directly under the Free Trade Agreement (FTA), rather than dealing with Israel to cover the 8 percent of product value added according to the QIZs agreement.

Nevertheless, the effects of these zones on the country have many advantages. The main advantages of the zones on the local economy are recorded in table 7.2. The outstanding results of table 7.2 led many observers to appraise the importance of QIZ to the economy. Regarding employment creations, the QIZs succeeded in attracting local employees from rural areas located near to the zones, as well as foreign employees from Far East countries such as India, Pakistan, Bangladesh and Sri Lanka. Total number of employees in all QIZs companies reached around 30,013 in 2004 according to MIT data. The tremendous increase in exports and jobs created by companies operating in the zones led the government to pay more attention to them, and expand them around the country. Officials from Jordan and the USA have praised QIZs for helping to spark economic growth in the country through exports and reduce unemployment. Others observers note that QIZs, while promoting Israel, USA, and Jordan trade; have had modest impact on

\footnotetext{
${ }^{78}$ Pete W. Moore, 2003: The Newest Jordan: Free Trade, Peace and an Ace in the Hole online, June 26.
} 
Jordan’s economy $^{79}$. Table 7.2 shows the main development of QIZs over the years 1999 to 2004, according to the MIT published data.

Table 7.2: Employment and Value of Exports in the QIZs

\begin{tabular}{|c|c|c|c|c|c|c|}
\hline & 1999 & 2000 & 2001 & 2002 & 2003 & 2004 \\
\hline Employment & 4.000 & 6.584 & 19.000 & 23.503 & 28.639 & 30.013 \\
\hline Locals & 1.400 & 2.500 & 13.300 & 13.867 & 16.175 & 16.770 \\
\hline Foreign & 2.600 & 4.084 & 5.700 & 9.636 & 12.464 & 13.243 \\
\hline $\begin{array}{llll}\text { Export from } & \text { QIZs } & \text { (US\$ } \\
\text { Million) } & & & \\
\end{array}$ & 2.4 & 25.1 & 150.3 & 381.7 & 574.0 & 1121.2 \\
\hline
\end{tabular}

Source: Industrial Development Directorate, Ministry of Industry and Trade

Note: Number of employees is accumulated every year, and different from the results of the field research.

\subsection{Political Assessment}

In chapter five, we gave a full analysis and description about the characteristics of investors and companies operating in the QIZs. It gives the main advantages and disadvantages of these zones to the local economy. Moreover, it shows the shortcoming and the ability to overpass these shortcomings in the future. In order to give more of an in depth analysis we will try to mention the most important criteria that we figured out from chapter five which seems to be more connected to the political performance. The following is a brief summary about the most important criteria that may play a role in enhancing the political performance in the future.

\subsubsection{Investors’ Nationality}

The QIZs attract investors from different countries, the study shows that around 79 percent of the investors are from Far East countries such as India, Sri Lanka, Pakistan, and China. In contrast, investors from America, Canada, and Europe made up 8 percent. Jordanian investors had a share of around 8 percent, while Israeli investors represented only 2.6 percent of all investors, thus seeming least interested in investing in the QIZs (see chapter 5, section 5.2.2). This result is contrary to the expectation, because those zones aimed mainly to attract local and Israeli investors in order to improve relations between Israeli and Jordanian investors, through creating interaction between the two sides when investing in the QIZs. One way to overlook this shortcoming is by giving

\footnotetext{
${ }^{79}$ See CRS Report for Congress, December 9, 2004.
} 
local investors more incentives to invest in these zones and to encourage them to work side by side with other investors. It is important to bear in mind that increasing the number of local investors operating in the zones will lead to an increase in the interaction between the two sides. In the end it will also lead to improve the relation between the two countries. At the same time this will ensure the continuous survival of these zones in the future.

\subsubsection{Input Requirements}

The main idea behind establishing the QIZs is to combine the Israelis and the Jordanian inputs together in a way that will benefit the two sides of the agreement and will lead to create business interaction. The agreement stipulates that at least 7 to 8 percent of the value added of the product produced in the QIZs must be from Israel. However, the finding from the field research reveals the main constraints facing the investors to cover the required Israeli share. Investors showed difficulty related to input and raw material imported from Israel in addition to the preferred agreement by the investors to work under it. About one third (31.6 percent) of the sample companies said that they had experienced problems with the fulfillment of the required 7 to 8 percent of inputs from Israel to meet the value added requirements. This problem appeared because companies in QIZs are forced to import the 7-8 percent of value only from Israel. Respondents indicated that they were obliged to buy and import products from Israel even though these products were very expensive compared to other countries. In our opinion, this problem will affect investors' ability to continue investing in the future unless a set of measures are going to be undertaken. For example the Israeli side can decrease the requirements of the 8 percent value added by applying value added brackets. These brackets should depend on the volume of production for every investor. In this mechanism when the investor increases the volume of production, the required inputs and value added should decrease. This will give the investors more flexible choices and at the same time will ensure more increase in export and of course will lead to more interaction between the two sides. Another step from the Israeli side should be by offering reasonable prices for the products and accessories that are selling to the investors in the 
zones. This of course, will keep the investors working and increase their profitability. At the same time, this will lead to more demand from the investors for the Israeli products and in the end will ensure more interaction between all parties.

\subsubsection{Type of the Agreement}

Investors show a high willingness to shift from working under the QIZs agreement to the Free Trade Agreement (FTA) ${ }^{80}$. Thus, around 57.9 percent of the respondents indicated that they preferred to work under the FTA with the USA in order to avoid dealing with Israeli companies and to have the choice to import the raw materials and inputs from anywhere in the world with reasonable prices. Apparently, this kind of obstacles can be harmful to the continuity of investors to work under the QIZs agreement in the future. As indicated in the previous section, enhancing the procedures for the investors will lead to create a healthy environment and this will lead to better understanding from the investors to remain operating under these zones. The advantage that the investors have is that they can shift from working under QIZs agreement to FTA agreement and vise versa without any difficulties. What postponed investors to shift to work under the FTA is because the USA still imposes quota and custom duties on the textile and apparel products which are the major production of the zones. According to the FTA agreement the custom duties will be eliminated gradually by the year 2012. This of course will shift investors to work under the FTA with the USA direct without the need to cover the 8 percent of value added and dealing with Israeli companies. However, there are some companies start to work under the FTA agreement along with the QIZ agreement in order to transfer completely to FTA in the near future.

\subsection{Prudent Planning}

This section discusses the appropriateness of including some policy measures to ensure prudent planning for the QIZs either in Jordan or in other countries in the future. These policy measures should be determined before and after establishing these zones. The

\footnotetext{
${ }^{80}$ Free Trade Agreement (FTA) refers to the agreement between Jordan and the USA signed in 2001, where Jordanian goods can be export to the USA market duty-free.
} 
purpose of these measures would be limited to covering the shortfalls that could arise during the establishment of the zone due to unanticipated events, such as closures of the companies, imposing new taxes or even eliminating exemptions. These measures would depend to some extent on the degree of caution already reflected in this study and related to the investors' point of view. In order to apply this methodology, we will try to set some policy options to adopt it in the future.

\subsubsection{Policy options}

By establishing the zones by the Jordanian government we can consider it a right step in achieving the main goals of the country in the long run. This includes enhancing the political situation gradually, creating jobs for local individuals and boosting the economic growth. Creating employment for local persons was the main effect of establishing these zones. Without these zones, it is conceivable that Jordan would not have been able to create the much-needed jobs for the country's many unemployed, often-unskilled persons. The income these jobs generate plays a big role in enhancing family income for a lot of families, providing a means for poverty alleviation. Other effects were found to be limited, and sometimes having a negative impact - including on foreign currency earning, balance of payments, and taxes.

By increasing local investor participation in these zones and reducing the value added requirement from the Israeli side. This step will prevent investors from shifting to operate under other agreements. Therefore, this will lead to enhancing the political situation in the future. However, what we should consider in the future is keeping these zones operating in the country, because of its links with other sectors in the economy. In this regard we should not consider the closure of some companies nor employing foreign employees as a disadvantage, because we can still benefit from the existing companies in different ways. For instance, the zones pay wages to more than 11 thousand local employees by using utilities (e.g. electricity, water and sewage) and infrastructure (e.g. roads, phones and the like) this can benefit the country and have positive spillover on the economy, by creating networks of suppliers to the companies surrounding the zones and 
by using other related services. Moreover, Jordan can benefit more from these zones if some fiscal measures can be applied on the companies operating in these zones.

\subsubsection{Fiscal Options}

There are different sources of tax exemptions offered to the companies operating in the QIZs. Tax exemptions for the investors in the QIZs companies are not as valuable as in other sectors. The government should revise these exemptions offered to the investors. For instance, the study shows that tax exemptions offered to the companies from the Jordan Investment Board and other semi-government organizations are not valuable to the investors as much as exporting to the USA market quota and duty-free (see chapter 5, section 5.5.2). In particular, investors do not pay any attention to the tax exemptions which can be considered as forgone revenue to the government. In this case, the government can benefit from this situation either by eliminating the tax exemptions or by imposing new taxes. Of course, some will argue that this policy is not applicable and will shift the investors to other countries. While investors do not pay any attention to the taxes because the agreement is more valuable to them, eliminating taxes on the companies are only a matter of increasing the investors' wealth in favor of the government. For example, it might be possible if the government can levy taxes on the companies operating in the QIZs differ from other companies operating in other sectors. In general, there are different options for taxation that can be followed by the government to ensure a healthy environment and avoid distortion of the economy. These options can work to increase the available resources to the government in a way that do not affect other taxpayers. And this will allow the government to use these resources to improve the standard of living for local employees as well as enhancing the vocational training. The following is a brief description of the fiscal options and measures that can be used by the government:

Option 1: Taxing the Gross Bill of Wages Paid by Companies Operating in the QIZs

In order to ensure that companies will not transfer taxes to other taxpayers such as local employees, the government can tax the gross bill of wages paid to foreign and local 
employees. In this regard taxing the gross wage bill will allow some revenue for the government. According to the field research there were more than thirty two thousand employees working in the QIZs. The number of foreign employees is around 21,300 employees, while for local employees it is around 11,138 employees. Wages paid by companies to employees are equivalent to about US\$ 77 million a year. Around 74 percent of the total wages paid to foreign employees and more likely the bulk of these wages transfer outside the country. If we suppose that, the government imposes 5 percent on the gross wages this will allow around US\$ 4 million as revenue. In the worse case scenario the companies can not pay less than the minimum wage to the local employees. This means that imposing this kind of tax will not affect the employees, because companies already have paid the minimum wage for the local employees.

Option 2: Taxing Exports and Imports

It is not preferable under free trade arrangement to tax either imports or exports. However, under the World Trade Organization (WTO) there are some cases that allow to tax exports. This kind of taxation if used will probably lead to allow more available resource for the government. Of course, in this case all exports should be taxed, to eliminate discrimination between exports from other sectors in the economy and exports from the zones. Recent data published by the MIT shows that exports from QIZs companies consist around 30 percent of total export. This number if taxed will allow a lot of revenue to the treasury. As much as investors benefit from the QIZs agreement there will be more resources to the government. It is not preferred to tax only exports from the QIZs, other sectors should be taxed too.

Option 3: Reducing the Grace Period of Tax Exemptions

The grace period referred in this context to the period of time that is offered to investors without paying taxes. According to the Jordan Investment Board (JIB), a time period of 10 years from tax exemptions are offered to the investors investing in the QIZs. Eliminating the grace period or even reducing it to e.g. one year will ensure more resources to the treasury from the companies operating in the zones. In particular, let us 
consider that the life cycle for some companies operating in the zones is between two to three years. In this case when the government reduces the grace period for the companies that benefit from the tax exemptions, it will ensure some resources to be utilized by the government from the companies that are looking only for fast profit.

Option 4: Reducing the Source of Tax Exemption

There are different semi-government organizations offering tax exemptions to the companies operating in the QIZs. Reducing the source of tax exemptions offered to the companies will ensure more resources and at the same time will reduce the period of time that companies are suppose to be taxed. This is because there are different tax holidays offered by several semi- government organizations. For example, the JIB offered income tax exemptions for ten years at the same time the Jordan Free Zone Corporation (JFZC) offered two years exemptions of income tax if the companies operate under the control of JFZC. The duplication in offering tax exemptions are only to the benefit of the companies in favor of the budget. Uniform the taxes to be from one source and it will ensure more resources to the treasury.

\subsubsection{Vocational Training and Employment in QIZs}

Chapter five contained a full analysis and description of the characteristics of local and foreign employees in the QIZs. In order to give more of an in-depth analysis, this section will highlight the most important criteria from the field research, namely the employment and vocational training performance.

\subsubsection{Employment}

Employment is one of the most important measurements of the economic impact of QIZs because of Jordan's high unemployment rate. In 2004, the unemployment rate in Jordan was 12.5 percent. Of the unemployed, 60 percent were below the age of 25 , in large part because 82 percent of young females were unemployed. According to the Jordan Human Development Report 2000, the causes of unemployment among young people were reluctance among educated Jordanians to take manual labor jobs, recurrent economic 
slow-downs since the 1980s, mismatch of the skills of graduates with the needs of employers, and poor in-job training and continuing-education programs. Ultimately, there simply are not enough desirable jobs being created to absorb the growth of Jordanian's labor force, (see table 7.3).

Table 7.3: Development of Labor Force and Unemployment 1999 - 2004

\begin{tabular}{|l|c|c|c|c|c|c|}
\hline & $\mathbf{1 9 9 9}$ & $\mathbf{2 0 0 0}$ & $\mathbf{2 0 0 1}$ & $\mathbf{2 0 0 2}$ & $\mathbf{2 0 0 3}$ & $\mathbf{2 0 0 4}$ \\
\hline Labor force & 910.000 & 1.000 .000 & 1.150 .000 & 1.250 .000 & 1.360 .000 & 1.410 .000 \\
\hline Unemployment & 121.940 & 137.000 & 169.050 & 191.250 & 197.200 & 176.250 \\
\hline Unemployment rate \% & 13.4 & 13.7 & 14.7 & 15.3 & 14.5 & 12.5 \\
\hline
\end{tabular}

Sources: World Fact Book different issues, World Bank, Ministry of Planning, and Author calculation.

The field research showed that companies in the QIZs were able to create and maintain a significant number of jobs, but that an increasing number of those jobs went to foreign workers in Jordan. The study shows the percentage of local employees in the QIZs dropped to 40 percent in 2004 from 49 percent in 2002 (see table 7.4).

Table 7.4: Job Created by QIZs Companies

\begin{tabular}{|c|c|c|c|c|c|c|c|c|c|c|c|c|}
\hline \multirow[b]{2}{*}{ Job Created } & \multicolumn{2}{|c|}{$\begin{array}{c}\text { Al } \\
\text { Tajamouat } \\
\text { Industrial } \\
\text { City }\end{array}$} & \multicolumn{2}{|c|}{$\begin{array}{c}\text { Al Hassan } \\
\text { Industrial } \\
\text { Estate }\end{array}$} & \multicolumn{2}{|c|}{$\begin{array}{c}\text { Al Dulayl } \\
\text { Industrial } \\
\text { Park }\end{array}$} & \multicolumn{2}{|c|}{$\begin{array}{c}\text { Al Hussein } \\
\text { Bin } \\
\text { Abdullah } \\
\text { II (Karak) }\end{array}$} & \multicolumn{2}{|c|}{$\begin{array}{l}\text { Cyber City } \\
\text { Park }\end{array}$} & \multicolumn{2}{|c|}{ Total } \\
\hline & No. & $(\%)$ & No. & $(\%)$ & No. & $(\%)$ & No. & $(\%)$ & No. & (\%) & No. & $(\%)$ \\
\hline Foreign & 4555 & 61.3 & 1488 & 38.4 & 3956 & 71.9 & 390 & 60.9 & 390 & 73.6 & 10779 & 60.0 \\
\hline Local & 2877 & 38.7 & 2382 & 61.6 & 1545 & 28.1 & 250 & 39.1 & 140 & 26.4 & 7194 & 40.0 \\
\hline Total & 7432 & 100 & 3870 & 97 & 5501 & 94 & 640 & 100 & 530 & 100 & 17973 & 100 \\
\hline
\end{tabular}

Source: Field Research

The decline in the percentage of local workers was explained by several factors. First, the turnover of local workers was very high, with an average of 20 employees leaving per month. Local employees were disinclined to see the work in the QIZs as contributing to their careers, especially because working in garments is socially undesirable in Jordanian society. The companies and investors also contribute to the declining percentage of local workers by only offering them low-wage, low value-added jobs with little chance for technology transfer, promotion to higher levels of responsibility, or wage increases. 
In the QIZs, 62.7 percent of total employment was considered skilled and 37.3 percent unskilled. According to the vast majority of sample companies, local employees are considered unskilled and foreign employees skilled. Only 5 percent of local employees are considered to be skilled. This is very disappointing, as the QIZs are meant to transfer technology and know-how to local employees. Nevertheless, the companies themselves offered unskilled jobs to local employees because they consider them unproductive compared to foreign workers. Table 7.5 shows number of skilled and unskilled employees in QIZs.

Table 7.5: Number of Skilled and Unskilled Employees in 2004

\begin{tabular}{|l|c|c|c|c|c|c|c|c|c|c|c|c|}
\hline $\begin{array}{l}\text { Number of Skilled and } \\
\text { Unskilled Employees }\end{array}$ & No. & $\mathbf{( \% )}$ & No. & $\mathbf{( \% )}$ & No. & $\mathbf{( \% )}$ & No. & $\mathbf{( \% )}$ & No. & (\%) & No. & (\%) \\
\hline Skilled & 7310 & 62.1 & 3409 & 54.6 & 5784 & 74.6 & 1458 & 46.6 & 1431 & 70.8 & 19392 & 62.7 \\
\hline Unskilled & 4463 & 37.9 & 2836 & 45.4 & 1972 & 25.4 & 1674 & 53.4 & 589 & 29.2 & 11534 & 37.3 \\
\hline Total & $\mathbf{1 1 7 7 3}$ & $\mathbf{1 0 0}$ & $\mathbf{6 2 4 5}$ & $\mathbf{1 0 0}$ & $\mathbf{7 7 5 6}$ & $\mathbf{1 0 0}$ & $\mathbf{3 1 3 2}$ & $\mathbf{1 0 0}$ & $\mathbf{2 0 2 0}$ & $\mathbf{1 0 0}$ & $\mathbf{3 0 9 2 6}$ & $\mathbf{1 0 0}$ \\
\hline
\end{tabular}

Source: Field Research

\subsubsection{Vocational Training}

Generally, QIZs companies started training local employees before and after take off. As for foreign employees, they have the knowledge and experience before coming to the country and they are excluded from training. Table 7.6 highlights the importance of vocational training offered to local employees by QIZs companies. It indicates that around two thirds (63.2 percent) of the sample companies stop offering vocational training for the new entrants, while only one third provide local employees with training. In fact, the respondents indicated that they have started to offer training for local employees in the early years of establishment, and after that they cease further training. This is because of the instability of local employees, as many respondents agreed that it is not profitable to them to spend time training local employees who will either quit their jobs or move to another company. In general, the vocational training offered to local employees in the QIZs is very weak and not providing local employees with the knowledge, they require to develop or to be retained by the companies. These weaknesses resulted from both companies and vocational centers in providing local employees with the qualifications and skills to adapt to this kind of work in the future. 
Table 7.6: Vocational Training

\begin{tabular}{|c|c|c|c|c|c|c|c|c|c|c|c|c|}
\hline \multirow[b]{2}{*}{$\begin{array}{l}\text { Vocational } \\
\text { Training }\end{array}$} & \multicolumn{2}{|c|}{$\begin{array}{l}\text { Al Tajamouat } \\
\text { Industrial City }\end{array}$} & \multicolumn{2}{|c|}{$\begin{array}{c}\text { Al Hassan } \\
\text { Industrial } \\
\text { Estate }\end{array}$} & \multicolumn{2}{|c|}{$\begin{array}{c}\text { Al Dulayl } \\
\text { Industrial } \\
\text { Park }\end{array}$} & \multicolumn{2}{|c|}{$\begin{array}{c}\text { Al Hussein } \\
\text { Bin Abdullah } \\
\text { II (Karak) }\end{array}$} & \multicolumn{2}{|c|}{$\begin{array}{c}\text { Cyber City } \\
\text { Park }\end{array}$} & \multicolumn{2}{|c|}{ Total } \\
\hline & No. & (\%) & No. & (\%) & No. & (\%) & No. & (\%) & No. & $(\%)$ & No. & (\%) \\
\hline Yes & 3 & 18.8 & 6 & 66.7 & 2 & 22.2 & 2 & 100.0 & 1 & 50.0 & 14 & 36.8 \\
\hline No & 13 & 81.3 & 3 & 33.3 & 7 & 77.8 & 0 & 0.0 & 1 & 50.0 & 24 & 63.2 \\
\hline Total & 16 & 100 & 9 & 100 & 9 & 100 & 2 & 100 & 2 & 100 & 38 & 100 \\
\hline
\end{tabular}

Source: Field Research

In order to cover this shortage in training, the government launched a new vocational training program aiming to provide new entrants to the labor market with basic knowledge to be capable to work. Precisely, training is targeting the new entrants and unqualified local employees in rural area, where unemployment is high, to provide them with a job in the QIZs companies. However, as has been reported by AMIR, the vocational training offered by the government has some shortfalls; for example, the training offered to the local employees is not adapted to the need of production lines in the QIZs companies ${ }^{81}$.

\subsubsection{Policy options}

Future implication of government policies concerning vocational training programs may be established by taking into account the available human and financial resources, the organization of work, future skill requirements, the need to anticipate industrial and technological changes, and the continuing of vocational training. These policies should be anticipated at national and company level in order to enhance the quality of local employees in the future.

\subsubsection{Policies at national level:}

At the national level, policies should concentrate upon enhancing local employees' quality and competitiveness among other foreign workers in the country as well as in the region. It should be ensured that training should provides means of anticipating of developments in production and changing in technology in order to improve and

\footnotetext{
${ }^{81}$ AMIR Program, (2001). Review of the Effectiveness and impact of Jordanian Investment Incentives, QIZ Labor Study.
} 
strengthen the competitiveness of local employees in the future. Moreover government policy should focus upon enhancing work conditions for local employees through providing them with good vocational training suiting the needs of the companies and giving them more incentives to stay at work. In addition the government should encourage unemployed individuals with inadequate qualifications in continuing vocational training in order to reintegrate them into the labor market. According to the current situation and the increasing number of foreign employees government policy should concentrates to gradually phase out foreign workers, replacing them with local ones as the latter's skills and knowledge of the business increase. It is important when setting up such zones to ensure availability of local workers with different levels of skilled to meet investors demand. Otherwise, we have to accept the high costs of increasing number of foreign employees and unemployment among locals. The high costs can result if the country does not have adequate infrastructure or enough levels of skilled workers to attract sophisticated technology investors in the future.

\subsubsection{Policies at company level:}

Government policies should be concentrate to raise awareness among and within companies and encouraging them to give priority to improving the quality and skills of their employees and to establish training plans and programs appropriate to their size and business objectives for future planning. The government should provide local employees with incentives, technical support measures, and good work conditions which are appropriate, necessary, and adequate for facing industrial changes. Moreover, develop continuing vocational training in order to make it an important feature of local development by taking into account the specific needs of the economy. Establishing of partnerships between vocational training centers and companies either in QIZs or in other part of the economy, to meet the requirements of both employees and employers by provide latest information on training opportunities in order to match supply and demand. These measures could help to encourage vocational training and ensure retaining of local employees in these zones. 
In general, local employees can retain work in QIZs if they are provided with good incentives and good work conditions as indicated by the investors who employed the vast majority of employees from among locals. Also this result suggests that QIZs have a greater ability to create jobs for local employees than what they do now, in a way that they could be considered an engine for creating jobs greater than other sectors in the economy.

Finally, it is possible to preserve these zones in the future, if local employees skilled meet investor's requirements and demand for different level of industries. It is imperative when planning to set up such zones to ensure a sufficient supply of skilled local workers. Otherwise, we will face the same problem that we have now with foreign workers filling a large portion of the jobs in these zones. In time, it is possible to acclimate local workers to work in a multinational corporation, including learning the skills that are necessary to move into the jobs currently occupied by foreign workers.

\subsection{Conclusion}

In general, the QIZs should be moderately taxed. There is no need for generous tax incentives as taxes cannot affect investors' decisions to come and invest in the country. Because there are other factors more important for the investors than taxes like political stability and the quota and duty-free exports to the USA market. Moderate tax incentives and rational indirect taxes and fees to impose on the QIZs companies can support the budget with more resources and at the same time this will ensure some resource and benefit for the country. Regarding the political options there is an important question that should be asked, whether it is enhancing the economic situation should be considered first in order to enhance the political situation, or is enhancing the political situation considered the priority, in a hope that economic cooperation will follow afterwards? It is interesting to know that the answer to this question is divulged clearly from the analysis of the investors' point of view. They show that the establishment of QIZs between Jordan and Israel stipulated a sequence for enhancing political issues, but it did not succeed as a first choice in order to help improve the political relationship between the two countries. 
Therefore, enhancing the political situation between the two countries should be the priority in order to ensure the success of the QIZs in Jordan as well as in other countries planning to adopt these kinds of zones in the future. Concerning vocational training government policies should work toward taking into account the available human and financial resources, the organization of work, future skill requirements, the need to anticipate industrial and technological changes, and the continuing of vocational training. These policies should be anticipated at national and company level in order to enhance competitiveness and quality of local employees in the future. It is possible to preserve these zones in the future, if local employees skilled meet investor's requirements and demand for different level of industries. In time, it is possible to acclimate local workers to work in a multinational corporation, including learning the skills that are necessary to move into the jobs currently occupied by foreign workers. 


\section{CHAPTER 8}

\section{CONCLUSION}

This thesis set out to investigate the fiscal and economic impact of QIZs on the host country. As with other types of industrial zones, countries cannot treat QIZs objectives separate from the objectives of the rest of the country, or ignoring their impact on the economy. A country planning to establish QIZs should be able to collect some of the value created in these zones to benefit their citizens. If improperly structured, the establishment of industrial zones can accrue net costs to the host country rather than net benefits.

When countries establish industrial zones, it is recommended to take into consideration the future impact on the overall economy and not only the short-term outcomes. Such outcomes can benefit a country for a long time, but there are examples that show industrial zones failing to bring significant benefits (Tekere, M. 2000). When countries follow prudent planning for establishing such zones, it is more likely that these countries will succeed in achieving their objectives.

QIZs are often touted as a solution to conflicts between countries because they encourage economic and political cooperation. In the previous chapters, we show that the experience of establishing QIZs is a mixture of failure and success. While economic data are impressive, improvements in political relations are far less so. It is important to take the

actual political situation of the country into account before applying and establishing these zones. Because these zones are complex policy instruments.

The needs of the country have to be taken into account when establishing these zones. Establishing QIZs might immediately and obviously benefit some areas, but it takes time and deliberate effort for the benefits to spread to the whole country. In this particular case, it is also imperative to understand that QIZs alone cannot solve the conflicts 
between Israel and other Middle Eastern countries, even though they can contribute to some of the economic problems underlying this conflict.

The establishment of QIZs between Jordan and Israel aimed to improve the political relationship, but it has not been as successful as planners hoped. Therefore, improving the relations between the citizens of Jordan and Israel should be recognized as a necessary element of success of the QIZs in Jordan. It should also be part of the planning process as other countries explore adoption of such zones. Simultaneously, the governments of Jordan and Israel should continue in their efforts to restore and maintain peace in the region, while reforming the economy. Both are required to create a favorable economic environment for foreign investors.

In chapter 5, we show that the forgone revenues are considered one of the main negative effects of the QIZs on the local economy, as it does not receive high importance from the investors. However, in the short run, the fiscal effects of creating QIZs can be expected to be net negative. While in the long run, with timing out of tax exemptions and induced economic activity surrounding the QIZs, the net fiscal effects might turn out to be positive. Of course, this depends on the continuity of recent companies to stay working in the future.

A major lesson of the Jordanian QIZs experience for other countries is that the direct economic impact might be limited, while the costs can be very high. High costs can result if the country does not have adequate infrastructure or enough skilled workers to attract sophisticated technology investors. The generous incentives that the country offers to attract investors should be geared towards increasing the level and magnitude of technological sophistication of the products. Thus, when the products produced in these zones are less sophisticated, the incentives offered by the government should be reduced correspondingly.

Tax incentives should be offered on a graduated scale; the more sophistication of the final products, the more tax incentives they should have. The experience of Jordanian QIZs shows that tax incentives offered to investors are not a major reason why investors chose 
to produce in the QIZs, the government must be careful not to overestimate the possible influence of tax incentives on the investment decision of investors. If it is overestimated, the government will unnecessarily cede the benefits of the QIZs.

As the role of tax incentives is limited in the investors' decisions, QIZs should be moderately taxed rather than tax-free. There is no need for generous tax incentives, as taxes do not significantly affect investment in the country. Other factors, like the economic and political stability and the quota and duty-free exports to the USA market are much more important. Moderate tax incentives and rational indirect taxes and fees can support the budget with more resources and at the same time ensure some direct benefit for the country.

The most important economic benefits of QIZ to the host country are increasing employment and reducing poverty. QIZs bring jobs for the unemployed and underemployed population. Companies seeking low labor costs also tend to employ unskilled workers, who tend to have high poverty rates. Jobs created for unemployed, underemployed, and unskilled local workers provide opportunities to increase income and improve future job prospects - often these are otherwise unavailable.

It is important to note that the overall impact of QIZs on official unemployment statistics is minor. This is because these zones usually attract inactive local workers, 70 percent of them female, who are not counted in the official statistics. Also, investors will want some hiring of foreign workers. The structure of the QIZ agreements should therefore favor hiring of local workers. An alternative option is to encourage the gradual substitution of foreign workers as local workers increase their capabilities.

It is shown that QIZs play a significant role in increasing exports, accelerating economic growth, and earning foreign currency. However, QIZs also increase imports, which must be taken into account when evaluating the total economic impact. When taking into account imports, the net effects of exports on economic growth is limited. Therefore, depending heavily on an export-led growth strategy to stimulate and accelerate economic growth in the country should be treated with caution. The results of this study show that 
QIZs play a role in increasing the potential exchange earning to the country, but this increase is not as remarkable and significant as expected. As such, proponents of QIZs might quote figures that ignore the negative effects of imports and talk only about the benefits of exports.

Creating employment for local persons was the main effect of establishing these zones. Without these zones, it is conceivable that Jordan would not have been able to create the much-needed jobs for the country's many unemployed, often-unskilled persons. The income these jobs generate plays a big role in enhancing family income for a lot of families, providing a means for poverty alleviation. Other effects were found to be limited, and sometimes having a negative impact on foreign currency earning, balance of payments, and taxes.

The study shows that there are no significant forward linkages, because the drive of these zones is to produce goods only for export. While backward linkages seem to be more significant, linkages between QIZs companies and local producers are mostly limited to the provision of packaging materials and simple inputs. It is therefore hardly surprising that few backward linkages have developed between QIZ companies and local companies. The overall effects have not been as expected from the QIZs. Although there are effects to be observed, they are not obviously large or immediate.

The quantitative findings in chapter 6 suggest limited advantages from employing econometric models, even though the data are not sufficient for extensive econometric analysis. However, it is wise to handle the results of such econometric models with caution.

Future research on the relationship between QIZ's companies and the welfare of the host country - both at the company and industry level - need to address some measurement issues that affect the data quality. Extending cross section, time series data to increase the number of observations would be helpful. Construction of more specific company-level and industry-level models may also be needed. In the presence of the small sample size, 
we suggest to use panel data analysis in the future because it is considered more dynamic and using this data may help explain the impact of QIZs on the economy.

Concerning vocational training government policies should work toward taking into account the available human and financial resources, the organization of work, future skill requirements, the need to anticipate industrial and technological changes, and the continuing of vocational training. These policies should be anticipated at national and company level in order to enhance competitiveness and quality of local employees in the future.

Finally, it is possible to preserve these zones in the future, if a set of measures are undertaken. Providing skilled local labor to meet investor's requirements and demand for different level of industries should be a priority for the government. It is imperative when planning to set up such zones to ensure a sufficient supply of skilled local workers. Otherwise, we will face the same problem that we have now with foreign workers filling a large portion of the jobs in these zones. In time, it is possible to acclimate local workers to work in a multinational corporation, including learning the skills necessary to move into the jobs currently occupied by foreign workers.

Applying value added brackets from the Israeli side should depend on the volume of production by a given company. With this mechanism, when investors increase the volume of production, the required inputs and value added for them should decrease. It is also possible to decrease the prices of the inputs from Israel to keep investors working under these QIZs agreement and not shifting to other agreements. Of course, it is still possible, to preserve these zones and investors in the future, if the USA government gives these zones more privileges than to its other trade agreements. Applying these procedures will help create a healthy environment and will encourage investors to remain active in these zones. Furthermore, this study was conducted in the Jordanian QIZs business environment only. In order to strengthen the findings of this study internationally, future research should be conducted in a cross different countries. 


\section{APPENDICES}




\section{Appendix 1: The Questionnaire}

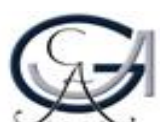

GEORG-AUGUST-UNIVERSITÄT

GÖTTINGEN

Department of Economics

The Fiscal and Economic Impact of

Qualifying Industrial Zones

Questionnaire

Thank you for agreeing to talk to me. This questionnaire is one of the requirements for my Ph.D. study. The University of Göttingen confirms that any information you divulge in this questionnaire will be held on an anonymous basis and treated in strictest confidence. The purpose of the research is to qualify theoretical prediction of the effect of Qualifying Industrial Zones (QIZs) on the Jordanian economy.

\section{Section A: The Interviewee}

1. Name of the interviewee-

2. Job title

3. Nationality of the investors

4. Name of the zone

5. Establishment year

6. Name of the company

7. Product Type

\section{Section B: The Company}

In this section we would like you to tell us something about the nature of your company and the initial start-up of the project.

1. What is the status of your company? (tick if appropriate)

Partnership

Private ownership

Branch to Mother Company

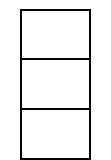

Other, please specify 
2. What is the type of the Qualifying Industrial Zone (QIZs) you are working in? (please circle number)

$\begin{array}{ll}\text { Private QIZ } & 1 \\ \text { Public QIZ } & 2\end{array}$

3. In your opinion, how easy was it for you to establish your project in the QIZs? (Please, tick if appropriate)

\begin{tabular}{|c|c|c|c|c|c|c|}
\hline Very difficult & & & & & & Very easy \\
\hline & 0 & $25 \%$ & $50 \%$ & $75 \%$ & $100 \%$ & \\
\hline
\end{tabular}

4. Can you please specify, the amount of investment used in the start-up stage of the company? (Please tick if appropriate)

Up to $1,000,000$ US\$

$1,000,001-2,500,000$ US\$

2,500,001 - 5000,000 US\$

More than 5000,000 US\$

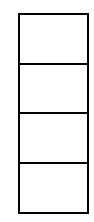

5. What were the main financial resources used at the start-up stage?

\begin{tabular}{|l|c|}
\hline & Percent \% \\
\hline Self finance & \\
\hline Bank borrowing & \\
\hline Partners and investors & \\
\hline
\end{tabular}

Others (specify please)

6. What were the main labor forces at the start up stage of the firm?

\begin{tabular}{|l|l|}
\hline & Percent \% \\
\hline Foreign & \\
\hline Locals & \\
\hline
\end{tabular}

7. Please, specify the amount of export of your company from the start up year? (By Jordanian Dinar)

\begin{tabular}{||l|l|l|l|l|l|l|l||}
\hline 1998 & 1999 & 2000 & 2001 & 2002 & 2003 & 2004 & 2005 \\
\hline & & & & & & & \\
\hline
\end{tabular}

8. Please, specify the amount of import of your firm from the start up year? (By Jordanian Dinar)

\begin{tabular}{||l|l|l|l|l|l|l|l||}
\hline 1998 & 1999 & 2000 & 2001 & 2002 & 2003 & 2004 & 2005 \\
\hline & & & & & & & \\
\hline
\end{tabular}


9. What is the relative cost of your production factors?

\section{Percent \%}

(Please, tick if appropriate)
a- Wages
b- Resident permission
c- Transportation
d- Raw materials
e- Rent

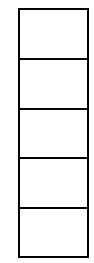

Other, please specify-

10. Can you please describe the production stage of your company? (Tick if appropriate)

\begin{tabular}{|c|c|c|c|c|c|c|c|c|c|c|c|}
\hline $\begin{array}{c}\text { Raw } \\
\text { material/ } \\
\text { Cotton }\end{array}$ & Spinning & Yarn & $\begin{array}{c}\text { Weaving } \\
\text { /Knitting }\end{array}$ & Drying & $\begin{array}{c}\text { Compacting } \\
\text { Drying } \\
\text { Smoothing }\end{array}$ & Fabric & Design & Cut & Make & Trim & $\begin{array}{c}\text { Garment } \\
\text { Product }\end{array}$ \\
\hline & & & & & & & & & & \\
\hline
\end{tabular}

11. Taking into consideration the transportations cost and transit time to USA market, what is the cost of transportations (shipment and trucking) and the transit time to USA market? (In Jordanian Dinar)

\begin{tabular}{|l||l|l|l|}
\hline & Shipment & Trucking & Transit Time \\
\hline Aqaba & & & \\
\hline Haifa & & & \\
\hline
\end{tabular}

12. Can you please indicate the amount of revenue and expenditure of the company for the last three fiscal years?

\begin{tabular}{|l||l|l|l|l||}
\hline & 2001 & 2002 & 2003 & 2004 \\
\hline Revenue & & & & \\
\hline Expenditure & & & & \\
\hline
\end{tabular}

\section{Section C: The Employee}

In this section we would like to know the effect of your project on the employment in the local economy.

1. How many new jobs would you say have been created/retained by the project? (Please specify number)

\begin{tabular}{|l|l|l|}
\hline & Created & Retained \\
\hline Local & & \\
\hline Foreign & & \\
\hline
\end{tabular}


2.Were any of the local employees taking these new jobs previously unemployed? (Please circle number)

$\begin{array}{ll}\text { Yes } & 1 \\ \text { No } & 2\end{array}$

If yes (please specify the number)

1.Did you find it difficult to obtain local employees for starting your business? (Please circle number)

$\begin{array}{ll}\text { Yes } & 1 \\ \text { No } & 2\end{array}$

If yes, please specify why-

4. Please specify the number of employees (Local and Foreign) of your firm including yourself?

\begin{tabular}{||c|c|c|c|c|c|c|c|c|c|c|c|c|c|c||}
\hline \hline \multicolumn{2}{|c|}{1999} & \multicolumn{4}{c}{2000} & \multicolumn{2}{c}{2001} & \multicolumn{2}{c|}{2002} & \multicolumn{2}{c|}{2003} & 2004 & 2005 \\
\hline \hline Local & Foreign & Local & Foreign & Local & Foreign & Local & Foreign & Local & Foreign & Local & Foreign & Local & Foreign \\
\hline & & & & & & & & & & & & & & \\
\hline
\end{tabular}

5. Roughly, what is the share of women from the total employment, in percent?

\begin{tabular}{|l||l|}
\hline & Percent \% \\
\hline Local & \\
\hline Foreign & \\
\hline
\end{tabular}

6. On average, how many hours per day the employee works in your company without overtime?

\begin{tabular}{|l||c|}
\hline & Daily \\
\hline Working hours per employee & \\
\hline
\end{tabular}

7. On average, how many hours per day is the overtime of the employee?

\begin{tabular}{|l||c|}
\hline & Daily \\
\hline Overtime per employee & \\
\hline
\end{tabular}


8. What is the daily amount of production per employee in your company?

\begin{tabular}{|l|c|}
\hline & Daily (pieces) \\
\hline Production per employee & \\
\hline
\end{tabular}

9. In your view, is there any transfer of employment from your company to other companies? (Please circle a number)

$\begin{array}{ll}\text { Yes } & 1 \\ \text { No } & 2\end{array}$

If yes, please specify why?

10. How can you describe the monthly wage structure in your company for skilled and unskilled employees (in JD / Month)?

\begin{tabular}{||l||l|l||}
\hline & Skilled & Unskilled \\
\hline \hline Less than 100 & & \\
\hline $100-150$ & & \\
\hline $150-200$ & & \\
\hline $200-250$ & & \\
\hline $250-350$ & & \\
\hline $350-500$ & & \\
\hline More than 500 & & \\
\hline
\end{tabular}

11. What is the number of skilled and unskilled employees working in you firm?

\begin{tabular}{|l||l|}
\hline & Number of employee \\
\hline Skilled & \\
\hline Unskilled & \\
\hline
\end{tabular}

12. Do you support vocational training for your employees? (Please circle number)

$\begin{array}{ll}\text { Yes } & 1 \\ \text { No } & 2\end{array}$

13. If yes, please specify the number of employees and cost of Vocational training per employee.

\begin{tabular}{|l|l|}
\hline Number of trainee & \\
\hline Cost of vocational training per employee (in JD) & \\
\hline
\end{tabular}




\section{Section D: The Fiscal and Economic impact of the project}

In this section we would like to ask you about the impacts of the project that have direct and indirect effects on the local economy. In addition we seek to discuss the nature of incentives that you obtained in order to invest in the QIZs.

1. In your view, what were the most important effects of the project on the country? (Please tick if appropriate)

a.Does the project introduce innovative management practices?

b.Does the project lead to develop new products/services?

c.Does the project develop new process?

d. Introduction of a leading-edge technology

e. Does the project apply new production technology for the first

$\mathrm{f}$. Does the project bring new marketing and distribution strategies?

2. What kind of technology does your project introduce? (please explain )

3. Is there any cooperation between your company and local companies outside the QIZ?

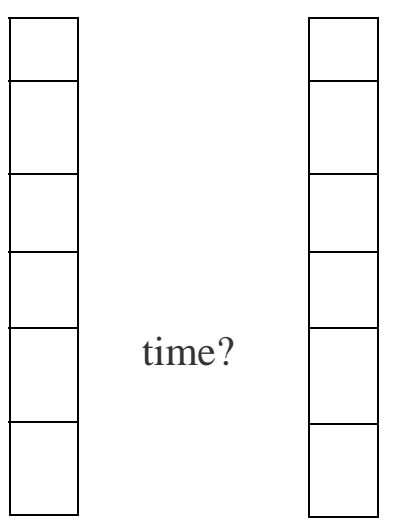

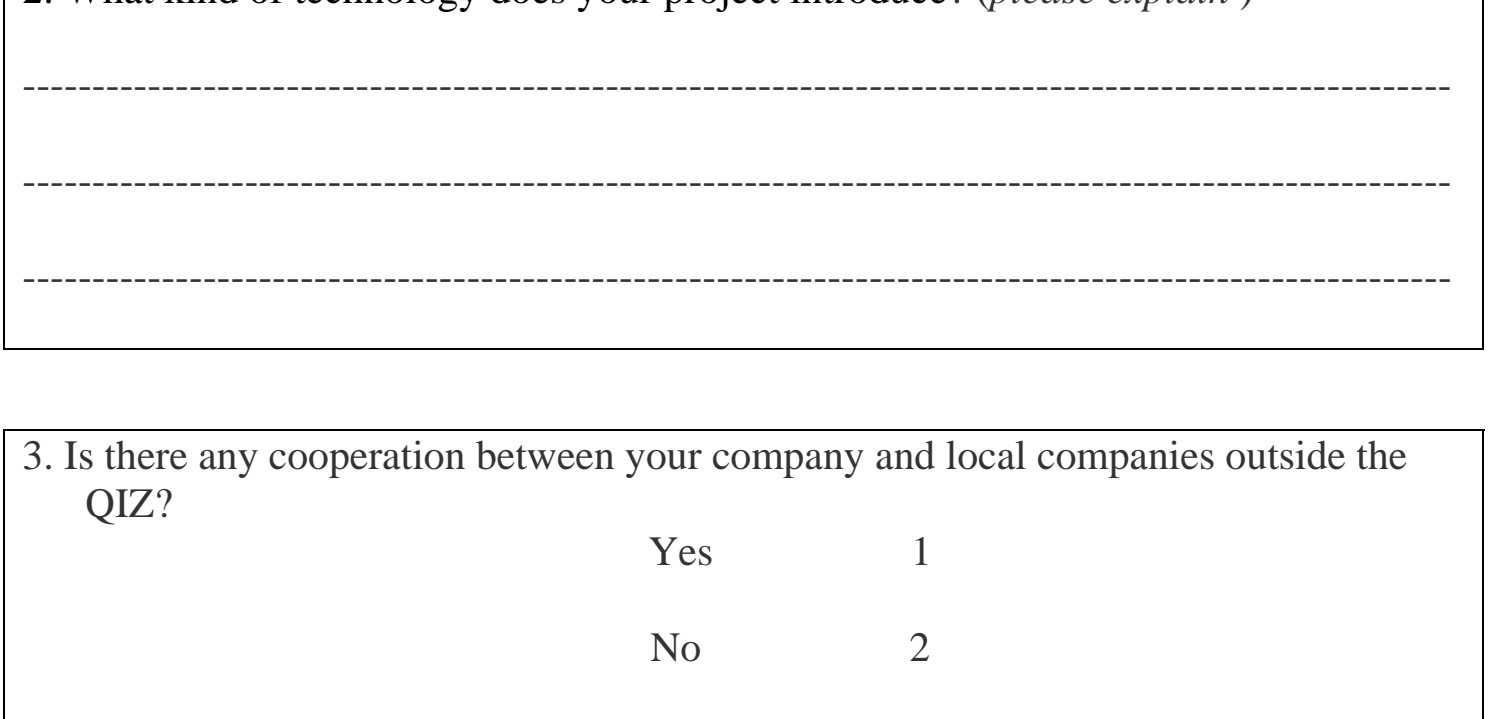

4. From which of the following you obtain tax incentives?(please, Tick if appropriate)
a.Jordan Investment Board
b.Industrial Estates Corporation
c.Jordan Free Zone Corporation
d.Other, please specify-

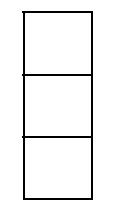


5. What kinds of incentives offered to you in order to start your project? (Please, Tick if appropriate)

\section{a. Income tax exemptions on:}

- social services tax

$\rightarrow$ profits exemptions

- wage exemption for non Jordanian employees

b. Customs duty exemptions on:

- fixed assets (e.g. equipment, machinery and tools)

- imported fixed assets for expansions

$\rightarrow$ imported raw materials

c. property taxes exemptions

d. Sales Tax

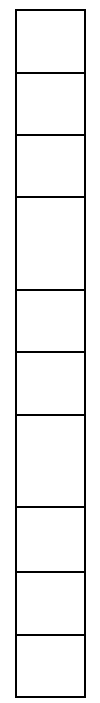

6. How much you estimates the amount of exemption offered to your project annually? (Please tick if appropriate)
a- up to 50,000 US\$
b- 50,001 - 100,000 US\$
c- $100,001-300,000$ US\$
d- 300,001 - 500,000 US\$
e- More than 500,000 US\$

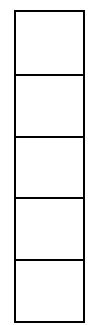

7. Can you please, rank the main reasons for you to invest in the QIZs?

$\begin{array}{lccccccc}\text { a. Duty and quota free to USA market } & \text { Low } & 1 & 2 & 3 & 4 & 5 & \text { high } \\ \text { b. Tax exemption } & \text { Low } & 1 & 2 & 3 & 4 & 5 & \text { high } \\ \text { c. Political stability } & \text { Low } & 1 & 2 & 3 & 4 & 5 & \text { high } \\ \text { d. Economic stability } & \text { Low } & 1 & 2 & 3 & 4 & 5 & \text { high } \\ \text { e. Investment climate } & \text { Low } & 1 & 2 & 3 & 4 & 5 & \text { high } \\ \text { f. Cheap labor force } & \text { Low } & 1 & 2 & 3 & 4 & 5 & \text { high }\end{array}$

j. Other, pleas specify 


\section{Section E: The Future Scheme of QIZs}

Finally, this section is designed to help us to understand your general view of the future of the QIZ's industry in Jordan.

1. What is better for you to produce under QIZ agreement or FTA agreement? (Please, Circle number)

$\begin{array}{ll}\text { QIZ } & 1 \\ \text { FTA } & 2\end{array}$

2. Is it easy for you to obtain the value added requirements to export under QIZ agreement? (please, circle number)

$\begin{array}{ll}\text { Yes } & 1 \\ \text { No } & 2\end{array}$

If no please explain why

3. Do you think that the QIZs scheme in Jordan have advantages over other free zones and QIZs in the region in respect to the following : (Please tick if appropriate )
a- Labour Force
b- Tax Exemptions
c- USA Market
d- EU Market
e- Transportation

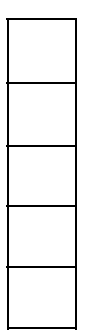

4. In your view, are there any disadvantages? (Please explain)

5. In your view, is there any challenge to your project from opening new QIZs in neighboring countries? (please circle number)

$\begin{array}{ll}\text { Yes } & 1 \\ \text { No } & 2\end{array}$

If yes ,please explain why 
6. What do you prefer more working under QIZs status or under Free zone status? (Please circle number)

QIZs Status $\quad 1$

Free Zones Status 2

Can you explain why, please-

7. In your view, which of the following can affect the strengthen of the company? (Please tick if appropriate)
a- Finance
b- Local Labour Market
c- Prices of Imported Raw Materials
d- Competition
e- Marketing
f- Government Regulations
g- Political stability

Other (Specify please)

8. Have you any other comments you would wish to make about the future scheme of QIZ's?

That is all. Thank you very much for your time. It has been very useful. 


\section{Appendix 2: Map of Active Qualifying Industrial Zones}

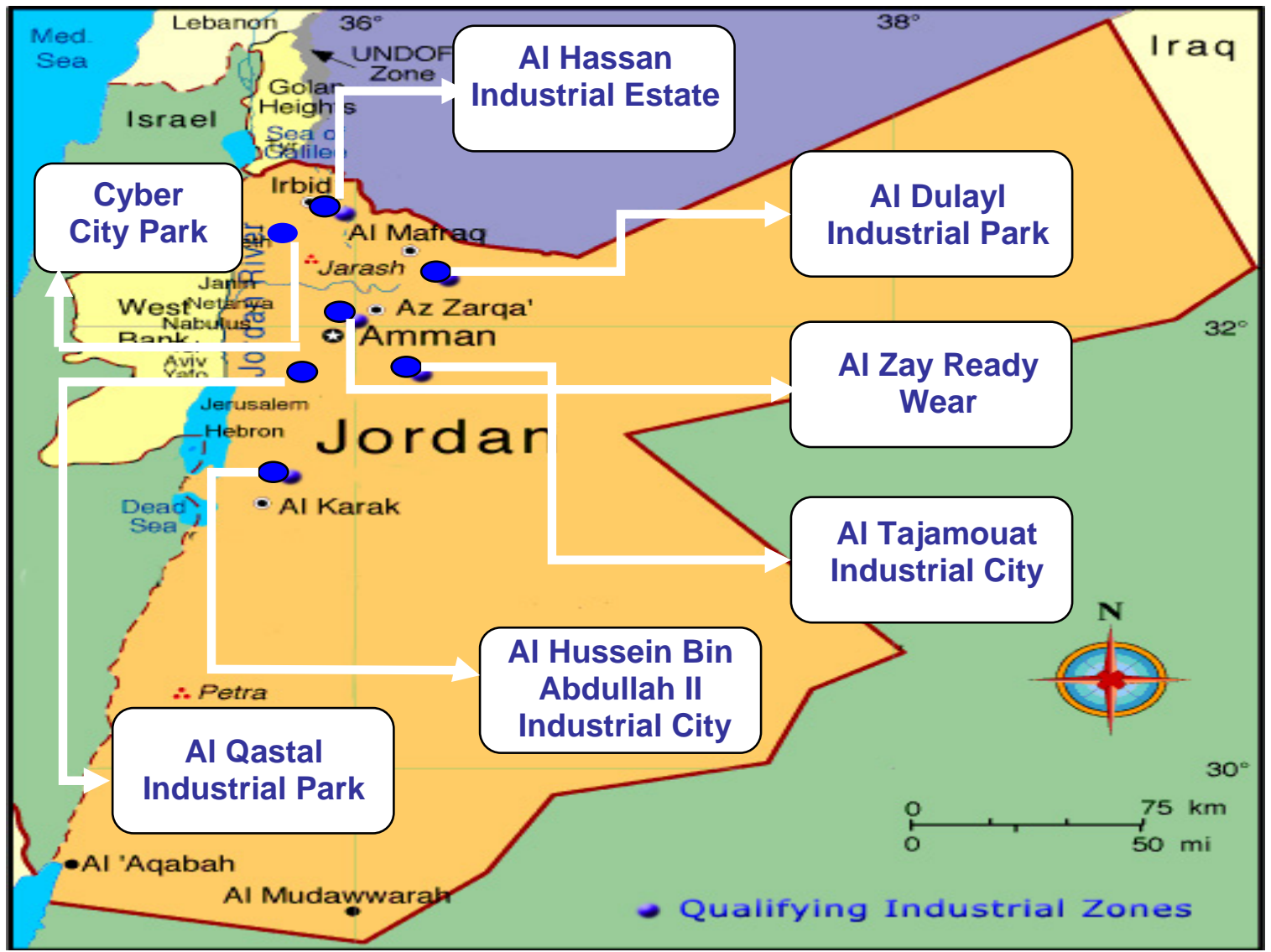

Source: General Trade Union of Workers on Textile, Garment and Clothes Industry 


\section{Appendix 3: Companies in the QIZs According to MIT Data for the year 2004}

\begin{tabular}{|c|c|c|c|c|c|c|}
\hline \multirow{2}{*}{ No. } & \multirow{2}{*}{ Company } & \multirow{2}{*}{ Location } & \multirow{2}{*}{$\begin{array}{c}\text { Establishment } \\
\text { Year } \\
\end{array}$} & \multicolumn{2}{|c|}{ Labor } & \multirow{2}{*}{$\begin{array}{c}\text { Total } \\
\text { Labor }\end{array}$} \\
\hline & & & & Locals & Foreign & \\
\hline 1 & Sari International & Al-Hassan & 2000 & 879 & 213 & 1,092 \\
\hline 2 & Millennium & Al-Hassan & 2000 & 333 & 152 & 485 \\
\hline 3 & Falcon Jordanian & Al-Hassan & 2000 & 677 & 537 & 1,214 \\
\hline 4 & Century Standard Tex & Al-Hassan & 2000 & 225 & - & 225 \\
\hline 5 & Century Miracle & Al-Hassan & 2000 & 495 & 290 & 785 \\
\hline 6 & Century Tailoring & Al-Hassan & 2001 & 900 & 50 & 950 \\
\hline 7 & Oasis & Al-Hassan & 2001 & 287 & 195 & 482 \\
\hline 8 & Business Faith & Al-Hassan & 2002 & 221 & 325 & 546 \\
\hline 9 & American Jordanian & Al-Hassan & 2003 & 1,007 & 534 & 1,541 \\
\hline 10 & Rolex & Al-Hassan & 2003 & 137 & 182 & 319 \\
\hline 11 & Al-Manar & Al-Hassan & 2003 & 64 & - & 64 \\
\hline 12 & Gals & Al-Hassan & 2003 & 380 & - & 380 \\
\hline 13 & International Business & Al-Hassan & 2004 & - & - & - \\
\hline 14 & Al Shamal & Al-Hassan & 2004 & - & - & - \\
\hline 15 & Classic Fation Apparel Industry & Al-Hassan & 2004 & - & - & - \\
\hline 16 & United Bright & Al-Hassan & 2004 & - & - & - \\
\hline 17 & Camel & Al- Karak & 2000 & 1,488 & 1,196 & 2,684 \\
\hline 18 & Honorway & A- Karak & 2001 & 274 & 174 & 448 \\
\hline 19 & Expo & A- Karak & 2005 & - & - & - \\
\hline 20 & New World Textile & Al-Tajamouat & 2001 & 603 & 43 & 646 \\
\hline 21 & Al-Aham & Al-Tajamouat & 2001 & 433 & 433 & 866 \\
\hline 22 & Maintrend & Al-Tajamouat & 2001 & 158 & 445 & 603 \\
\hline 23 & Canon County Knitting & Al-Tajamouat & 2001 & 627 & - & 627 \\
\hline 24 & United Garments & Al-Tajamouat & 2001 & 212 & 368 & 580 \\
\hline 25 & Jerash Garments & Al-Tajamouat & 2001 & 491 & 397 & 888 \\
\hline 26 & Best Medal & Al-Tajamouat & 2001 & 151 & 123 & 274 \\
\hline 27 & I-Texfil Jordan Ltd & Al-Tajamouat & 2002 & 321 & 109 & 430 \\
\hline 28 & Silver Planet & Al-Tajamouat & 2002 & 341 & 400 & 741 \\
\hline 29 & Formosa & Al-Tajamouat & 2002 & 159 & 184 & 343 \\
\hline 30 & Ivory & Al-Tajamouat & 2002 & 99 & 230 & 329 \\
\hline 31 & Al Qadi & Al-Tajamouat & 2002 & 39 & - & 39 \\
\hline 32 & Jordan Dragon & Al-Tajamouat & 2003 & 424 & 267 & 691 \\
\hline 33 & Prestige & Al-Tajamouat & 2003 & 50 & 190 & 240 \\
\hline 34 & Royal Fashion & Al-Tajamouat & 2003 & 38 & 37 & 75 \\
\hline 35 & Aseel & Al-Tajamouat & 2003 & 71 & 212 & 283 \\
\hline 36 & Al-Fan & Al-Tajamouat & 2003 & 18 & 69 & 87 \\
\hline 37 & Golden Wear & Al-Tajamouat & 2003 & 245 & 380 & 625 \\
\hline 38 & Pacific & Al-Tajamouat & 2004 & 25 & 145 & 170 \\
\hline 39 & Al tayyar & Al-Tajamouat & 2004 & - & - & - \\
\hline 40 & Atatex & Al-Tajamouat & 2005 & - & - & - \\
\hline 41 & Jordan Silk & Al-Tajamouat & 2005 & - & - & - \\
\hline 42 & Hi -Tech Textile & Ad- Dulayl & 2001 & 195 & 148 & 343 \\
\hline 43 & United Creations & Ad- Dulayl & 2001 & 537 & 656 & 1,193 \\
\hline 44 & Rainbow & Ad- Dulayl & 2001 & 185 & 919 & 1,104 \\
\hline 45 & Panorama & Ad- Dulayl & 2001 & 103 & 144 & 247 \\
\hline 46 & Petra Apparel & Ad- Dulayl & 2001 & 261 & 408 & 669 \\
\hline 47 & Mediterranean & Ad- Dulayl & 2001 & 393 & 607 & 1,000 \\
\hline 48 & Needle Craft & Ad- Dulayl & 2002 & 171 & 210 & 381 \\
\hline 49 & Fine Apparel & Ad- Dulayl & 2003 & 146 & 337 & 483 \\
\hline 50 & Mustafa \&Kamal & Ad- Dulayl & 2003 & 69 & 277 & 346 \\
\hline 51 & Sun Jordan & Ad- Dulayl & 2004 & 50 & 184 & 234 \\
\hline 52 & Beeline & Ad- Dulayl & 2004 & 234 & 389 & 623 \\
\hline 53 & Al-Qadir & Ad- Dulayl & 2004 & 286 & 61 & 347 \\
\hline 54 & Al Mateen & Ad- Dulayl & 2005 & - & - & - \\
\hline 55 & Ayam Maliban & Ad- Dulayl & 2005 & - & -- & - \\
\hline 56 & United Textile Group & Al- Qastal & 2001 & 598 & - & 598 \\
\hline 57 & Prime Five & Al- Qastal & 2002 & 388 & 267 & 655 \\
\hline 58 & El Zay Ready Wear & El- Zay & 2001 & 626 & - & 626 \\
\hline 59 & Rich Pine & Cyber City & 2001 & 333 & 437 & 770 \\
\hline 60 & Caliber Garment & Cyber City & 2002 & 225 & 319 & 544 \\
\hline & Total & & & 16,770 & 13,243 & 30,013 \\
\hline
\end{tabular}

Source: Ministry of industry and Trade.

Note: This table was obtained from MIT data base. 


\section{Appendix 4: Companies in the QIZs According to Field Research}

\begin{tabular}{|c|c|c|c|c|c|c|}
\hline \multirow{2}{*}{ No. } & \multirow{2}{*}{ Company } & \multirow{2}{*}{ Location } & \multirow{2}{*}{$\begin{array}{c}\text { Establishment } \\
\text { Year }\end{array}$} & \multicolumn{2}{|c|}{ Labor } & \multirow{2}{*}{$\begin{array}{c}\text { Total } \\
\text { Labor }\end{array}$} \\
\hline & & & & Locals & Foreign & \\
\hline 1 & Sari International & Al-Hassan & 2000 & & & \\
\hline 2 & Millennium & Al-Hassan & 2000 & \multicolumn{3}{|c|}{ Closed } \\
\hline 3 & Falcon Jordanian & Al-Hassan & 2000 & \multicolumn{3}{|c|}{ Refused to Fill the Questionnaire } \\
\hline 4 & Century Standard Tex & Al-Hassan & 2000 & & & \\
\hline 5 & Century Miracle & Al-Hassan & 2000 & & & \\
\hline 6 & Century Tailoring & Al-Hassan & 2001 & & & \\
\hline 7 & Oasis & Al-Hassan & 2001 & & & \\
\hline 8 & Business Faith & Al-Hassan & 2002 & & & \\
\hline 9 & American Jordanian & Al-Hassan & 2003 & \multicolumn{3}{|c|}{ Refused to Fill the Questionnaire } \\
\hline 10 & Rolex & Al-Hassan & 2003 & & & \\
\hline 11 & Al-Manar & Al-Hassan & 2003 & \multicolumn{3}{|c|}{ Refused to Fill the Questionnaire } \\
\hline 12 & Gals & Al-Hassan & 2003 & \multicolumn{3}{|c|}{ Closed } \\
\hline 13 & International Business & Al-Hassan & 2004 & & & \\
\hline 14 & Al Shamal & Al-Hassan & 2004 & \multicolumn{3}{|c|}{ Closed } \\
\hline 15 & Classic Fation Apparel Industry & Al-Hassan & 2004 & & & \\
\hline 16 & United Bright & Al-Hassan & 2004 & \multicolumn{3}{|c|}{ Refused to Fill the Questionnaire } \\
\hline 17 & Camel & Al- Karak & 2000 & & & \\
\hline 18 & Honorway & A- Karak & 2001 & & & \\
\hline 19 & Expo & A- Karak & 2005 & \multicolumn{3}{|c|}{ Refused to Fill the Questionnaire } \\
\hline 20 & New World Textile & Al-Tajamouat & 2001 & & & \\
\hline 21 & Al-Aham & Al-Tajamouat & 2001 & & & \\
\hline 22 & Maintrend & Al-Tajamouat & 2001 & & & \\
\hline 23 & Canon County Knitting & Al-Tajamouat & 2001 & & & \\
\hline 24 & United Garments & Al-Tajamouat & 2001 & & & \\
\hline 25 & Jerash Garments & Al-Tajamouat & 2001 & & & \\
\hline 26 & Best Medal & Al-Tajamouat & 2001 & & & \\
\hline 27 & I-Texfil Jordan Ltd & Al-Tajamouat & 2002 & & Close & \\
\hline 28 & Silver Planet & Al-Tajamouat & 2002 & & & \\
\hline 29 & Formosa & Al-Tajamouat & 2002 & & & \\
\hline 30 & Ivory & Al-Tajamouat & 2002 & & & \\
\hline 31 & Al Qadi & Al-Tajamouat & 2002 & & Close & \\
\hline 32 & Jordan Dragon & Al-Tajamouat & 2003 & & & \\
\hline 33 & Prestige & Al-Tajamouat & 2003 & & & \\
\hline 34 & Royal Fashion & Al-Tajamouat & 2003 & & Close & \\
\hline 35 & Aseel & Al-Tajamouat & 2003 & & & \\
\hline 36 & Al-Fan & Al-Tajamouat & 2003 & & Close & \\
\hline 37 & Golden Wear & Al-Tajamouat & 2003 & & to Fill the & naire \\
\hline 38 & Pacific & Al-Tajamouat & 2004 & & & \\
\hline 39 & Al tayyar & Al-Tajamouat & 2004 & & & \\
\hline 40 & Atatex & Al-Tajamouat & 2005 & & to Fill the & laire \\
\hline 41 & Jordan Silk & Al-Tajamouat & 2005 & & & \\
\hline 42 & Hi -Tech Textile & Ad- Dulayl & 2001 & & & \\
\hline 43 & United Creations & Ad- Dulayl & 2001 & & & \\
\hline 44 & Rainbow & Ad- Dulayl & 2001 & & & \\
\hline 45 & Panorama & Ad- Dulayl & 2001 & & & \\
\hline 46 & Petra Apparel & Ad- Dulayl & 2001 & & & \\
\hline 47 & Mediterranean & Ad- Dulayl & 2001 & & to Fill the & taire \\
\hline 48 & Needle Craft & Ad- Dulayl & 2002 & & to Fill the & naire \\
\hline 49 & Fine Apparel & Ad- Dulayl & 2003 & & & \\
\hline 50 & Mustafa \&Kamal & Ad- Dulayl & 2003 & & to Fill the & taire \\
\hline 51 & Sun Jordan & Ad- Dulayl & 2004 & & & \\
\hline 52 & Beeline & Ad- Dulayl & 2004 & & Close & \\
\hline 53 & Al-Qadir & Ad- Dulayl & 2004 & & & \\
\hline 54 & Al Mateen & Ad- Dulayl & 2005 & & Close & \\
\hline 55 & Ayam Maliban & Ad- Dulayl & 2005 & & & \\
\hline 56 & United Textile Group & Al- Qastal & 2001 & & Close & \\
\hline 57 & Prime Five & Al- Qastal & 2002 & & to Fill the & aire \\
\hline 58 & EI Zay Ready Wear & El- Zay & 2001 & & to Fill the & taire \\
\hline 59 & Rich Pine & Cyber City & 2001 & & & \\
\hline 60 & Caliber Garment & Cyber City & 2002 & & & \\
\hline & Total & & & & & \\
\hline
\end{tabular}

jource: Field research. 
Appendix 6: Main Economic Indicators in Logarithms and Ratio between 1980 and 2004

\begin{tabular}{|c|c|c|c|c|c|c|}
\hline Year & $\begin{array}{c}\text { Log } \\
\text { Domestic } \\
\text { Exports }\end{array}$ & $\begin{array}{c}\text { Log } \\
\text { Imports }\end{array}$ & $\begin{array}{l}\text { Log } \\
\text { Real } \\
\text { GDP }\end{array}$ & $\begin{array}{c}\text { Log } \\
\text { Manufactured } \\
\text { Export }\end{array}$ & $\begin{array}{l}\text { Domestic } \\
\text { Exports } \\
\text { as share } \\
\text { of GDP }\end{array}$ & $\begin{array}{l}\text { Manufactured } \\
\text { Export as } \\
\text { share of GDP }\end{array}$ \\
\hline 1980 & 5.654 & 7.131 & 7.944 & 3.018 & 10.129 & 0.725 \\
\hline 1981 & 5.859 & 7.315 & 8.102 & 3.417 & 10.610 & 0.923 \\
\hline 1982 & 5.863 & 7.386 & 8.170 & 3.634 & 9.950 & 1.071 \\
\hline 1983 & 5.806 & 7.441 & 8.148 & 2.952 & 9.613 & 0.554 \\
\hline 1984 & 6.209 & 7.363 & 8.190 & 3.797 & 13.791 & 1.237 \\
\hline 1985 & 6.217 & 7.392 & 8.162 & 3.593 & 14.295 & 1.036 \\
\hline 1986 & 6.243 & 7.442 & 8.218 & 2.815 & 13.876 & 0.450 \\
\hline 1987 & 6.415 & 7.478 & 8.239 & 3.189 & 16.146 & 0.641 \\
\hline 1988 & 6.532 & 7.533 & 8.253 & 3.367 & 17.881 & 0.755 \\
\hline 1989 & 6.582 & 7.345 & 8.140 & 3.508 & 21.047 & 0.974 \\
\hline 1990 & 6.543 & 7.387 & 8.137 & 3.564 & 20.318 & 1.032 \\
\hline 1991 & 6.414 & 7.376 & 8.153 & 3.301 & 17.570 & 0.782 \\
\hline 1992 & 6.508 & 7.691 & 8.287 & 3.770 & 16.881 & 1.092 \\
\hline 1993 & 6.585 & 7.777 & 8.331 & 4.003 & 17.443 & 1.319 \\
\hline 1994 & 6.677 & 7.768 & 8.380 & 3.701 & 18.218 & 0.929 \\
\hline 1995 & 6.760 & 7.736 & 8.440 & 3.725 & 18.649 & 0.896 \\
\hline 1996 & 6.733 & 7.810 & 8.460 & 3.721 & 17.781 & 0.875 \\
\hline 1997 & 6.789 & 7.786 & 8.493 & 3.859 & 18.190 & 0.972 \\
\hline 1998 & 6.826 & 7.726 & 8.523 & 4.234 & 18.332 & 1.372 \\
\hline 1999 & 6.856 & 7.721 & 8.555 & 4.249 & 18.276 & 1.348 \\
\hline 2000 & 6.929 & 7.909 & 8.598 & 4.823 & 18.848 & 2.293 \\
\hline 2001 & 7.140 & 7.944 & 8.649 & 5.507 & 22.118 & 4.322 \\
\hline 2002 & 7.277 & 7.967 & 8.705 & 5.948 & 23.976 & 6.347 \\
\hline 2003 & 7.349 & 7.990 & 8.746 & 6.266 & 24.720 & 8.375 \\
\hline 2004 & 7.554 & 8.195 & 8.827 & 6.545 & 28.004 & 10.213 \\
\hline
\end{tabular}

Sources: Central Bank of Jordan and author calculation 


\section{REFERENCES}

Abdul Jalil, M. (2004). Jordan and Israel Sign Key Upgraded Trade Accord Reuters, Al Jazeerah Arab News 24, December.

Abler, D. (2005). International Trade as engine for growth, international Development AG EG 450, Pennsylvania State University.

Abu al-Foul, B. (2004). Testing the export-led growth hypothesis: Evidence from Jordan, Department of Economics American University of Sharjah, Sharjah United Arab.

Abu-Qarn, A., and Abu bader, S. (2001). Export-led Growth, Empirical Evidence from the MENA Region, Department of Economics, Ben Gurion University,il.

Achievement of Market-Friendly Initiatives and Results (AMIR Program), (2001). Economic Impact and Implications for Jordan of the U.S.- Jordan Free Trade Agreement, U.S. Agency for International Development, February.

Achievement of Market-Friendly Initiatives and Results (AMIR Program), (2003). Investment Promotion Sectoral Strategy 2004-2006: Garment Sector, U.S. Agency for International Development, November.

Ahrens, J., and Baudeck A. (1995): Special Economic Zones in Central and Eastern Europe: Shortcut or Round about Way towards Capitalism? Inter economics, vol.30, No.2, pp 87-95.

Akbar, M., and Naqvi, Z. (2003). Are Exports an Engine of Growth in Pakistan? International Conference on Policy Modeling, Istanbul, Hotel Conrad, July 4, Session 2.

Al Arda, F., and Sahawneh, M. (1996). Study on Free zones in Jordan: Facts and Outlooks, the Royal Scientific Society, Amman.

Alex Easson (1998b). Duty-Free Zones and Special Economic Zones in Central and Eastern Europe and the Former Soviet Union, Tax Notes International, Vol. 16, p 445.

Al Khouri, R. (2000). Free Zones and Qualifying Industrial Zones (QIZs) in Jordan, The Arab Bank Review, Vol. 2, No. 2, October.

Al Khouri, R. (2001). Qualifying Industrial Zones as a Model for Industrial Development: Case of Jordan and its Implications for the Region, Friedrich-Elbert Stiftung, Amman office, can be found at www.fes-jordan.org, December.

Alrai Newspaper, (2004). Solving a problem of 150 workers from Bangladesh in Aldulayel zone, December, 24. 
Alrai Newspaper, (2005). Competitiveness matrix for Qualifying Industrial Zones, June 2.

Alul, G. (1997). Irbid's new industrial park leaves Jordanians divided, Jordan Times, Saturday, December 13.

Al-Yousif, Y. (1997). Exports and economic growth: some empirical evidence from the Arab Gulf countries, Applied Economics, 29, 6, pp 693-697.

Baier, S. L., and Bergstrand J. H. (2002). Economic Determinants of Free Trade Agreements, Journal of International Economics, Vol. 64, No. 1, pp 29-63, October.

Baissac, C. (1996). A critique of cost - benefit analysis in the evaluation of export processing zones, Presented at the WEPZA Round Table on EPZs, Vienna, No. 2 Ver. 1 April.

Baissac, C. (2003). Maximising the Developmental Impact of EPZs: A Comparative Perspective in the African Context of Needed Accelerated Growth, a Presentation at the Johannesburg EPZ Symposium, World Economic Processing Zones Association No. 7 Ver. 1.02 October.

Balassa, B. (1978). Exports and economic growth: Further evidence, Journal of Development Economics Vol. 5, No. 2, pp 181-189.

Balassa, B. (1985). Exports, policy choices, and economic growth in developing countries after the 1973 oil shock, Journal of Development Economics, Vol. 4, No. 1.

Barshefsky, C. (2000). Bridges to Peace: The US-Jordan Free Trade Agreement And American Trade Policy in the Middle East, Jordanian-American Business Association Amman, Jordan, July.

Baum C. F. (2001). Stata: The language of choice for time series analysis? The Stata Journal, November, pp 1 -16.

Bhagwati, J. and Srinivasan, T.N. (2002). Trade and Poverty in the Poor Countries, American Economics Review, Papers and Proceedings, Vol. 92 No. 2, pp 180-183.

Blomström, M. (1991). Host country benefits of foreign investment, NBER Working Paper No. 3615, February.

Blomström, M. (2002). The Economics of International Investment Incentives, OECD.

Blomström, M., and Kokko, A. (2003). The Economics of Foreign Direct Investment Incentives, NBER Working Paper No. 9489, February.

Bolle, M. J., Prados, A. B., and Sharp, J. M. (2006). Qualifying Industrial Zones in Jordan and Egypt, CRS Report for Congress, July. 
Bolle, M. J., et al., (2006). Qualifying Industrial Zones in Jordan: A Model for Promoting Peace and Development in the Middle East? CRS Report for Congress

Central Bank of Jordan, (2004). Annual Report, different issues, can be found at www.cbj.gov.jo, Government of Jordan.

Central Bank of Jordan, (2005). Monthly bulletin, different issues, can be found at www.cbj.gov.jo, Government of Jordan.

Chaudhuri, D. T., and Adhikari, S. (1993). Free Trade Zones with Harris-Todaro Unemployment: a Note on Young and Miyagiwa, Journal of Development Economics, Vol. 41, pp 159-167.

Chu, D. Y., and Ng, Y. T. (1982). The Costs of Four Special Economic Zones to China, Department of Geography, the Chinese University of Hong Kong, February.

Chu, D. Y. (1982). The Special Economic Zones of China, an economic - geographic appraisal, Department of Geography, the Chinese University of Hong Kong, March.

Cling, J., and Letilly, G. (2001). Export Processing Zones: A Threatened instrument for global economy insertion?, Document de travail DIAL / Unité de Recherche CIPRE Npvemebr.

Committee on Employment and Social Policy, (ESP) (2003). Employment and social policy in respect of export processing zones (EPZs), International Labour Office, Geneva, March.

Danish A. Hashim, (2004). Cost \& Productivity in Indian Textiles: Post MFA Implications, Indian Council for Research on International Economic Relations, Working paper No. 147, November.

Darrat, A. (1986). Trade and development: the Asian experience, Cato journal 6, 2, pp 695- 699

Deininger, K. and Squire, L. (1997). Economic Growth and Income Inequality: Reexamining the Links, Finance \& Development.

Department of Statistics, Trade statistics, can be found at www.dos.gov.jo, Government of Jordan.

DeRosa, D. A., and Roningen, V. O. (2003). Rwanda as a free trade zone, U.S. Mission to Rwanda, U.S. Agency for International Development, October.

Din, M. (1994). Export Processing Zones and Backward Linkages, Journal of Development Economics, Vol. 43, (March), pp 369-385. 
Dodaro, S. (1993). Exports and growth: a reconsideration of causality, Journal of Developing Areas Vol .27, pp 227-244.

Ellickson B., and Zame W. R. (2003). A Competitive Model of Economic Geography, Department of Economics, University of California, Los Angeles, August.

Emery, R. F. (1967). The relation of exports and economic growth, Kyklos, Vol. 20, No. 2 pp 470-486.

Emilio J. Medina-Smith, (2001). Is The Export-led growth Hypothesis valid For Developing Countries? A Case Study of Costa Rica, UNCTAD publication.

Facchini, G., and Willmann, G., (1998). The Gains from Duty Free Zones, Department of Economics, Stanford University, Stanford, CA 94305-6072, U.S.A., October.

Feder, G. (1983). On exports and economic growth, Journal of Development Economics Vol. 12, pp 59-73.

Forbes, K. J. (2000). A Reassessment of the Relationship between Inequality and Growth, American Economic Review, Vol. 90 No. 4, pp 869-887.

Frankel, J. A., and Romer, D. (1999).Does trade cause growth, American Economic Review, Vol. 89, No. 3, June.

Furman, J., and Stiglitz, J. (1998). Economic consequences of income inequality, Federal Reserve Bank of Kansas City, pp 221-263.

Gaffney, J. (2005). Jordan’s Qualified Industrial Zones: a Qualified Success? Master Thesis, University of Pennsylvania, USA.

General Trade Union of Workers in Textile, garment \& clothing industries, labor disputes, can be found at http://www.jtgcu.org/en/labor.htm

Giles J. A., and Williams C. L.(2000). Export-led Growth: A Survey of the Empirical Literature and Some Noncausality Results Part 1 Econometrics Working Papers, Department of Economics, University of Victoria

Glantz, A. (2003). Jordan's Sweatshops: The Carrot or the Stick of US Policy? Global Policy Forum, CorpWatch, February, 26. Can be found at http://www.corpwatch.org/article.php?id=5688

Granato, J. (1991). An Agenda for Econometric Model Building, Political Analysis, Oxford Journal, Vol. 3, No. 1, pp 123-154.

Granger, C. (1969). Investigating causal relations by econometric models and crossspectral methods, Econometrica, Vol. 37, pp 85-94. 
Greenaway, D. and Sapsford, D. (1994). What does liberalisation do for exports and growth,Weltwirtschaffliches Archiv, Vol. 130, No. 1 pp 152-174.

Guangwen, M. (2003). The Theory and Practice of Free Economic Zones: A Case Study of Tianjin, People's Republic of China, PhD thesis, University of Heidelberg, Germany.

Gugl, E., and Zodrow G. R. International Tax Competition and Tax Incentives in Developing Countri, International Studies Program Public Finance Conference, The Challenges of Tax Reform in a Global Economy.

Halpern, O. (2004). Jordan's peace dividend, the Jerusalem Post, internet edition 25 October.

Hamada, K. (1974). An Economic Analysis of the Duty-Free Zone, Journal of International Economics, Vol. 4, pp 225-241.

Hamdan, D. (2001). Israel blocks Jordan trade, Special to the Middle East Times.

Hamilton, C., and Svensson, L. (1982). On the Welfare Economics of a Duty-Free Zone, Journal of International Economics, Vol. 20, pp 45-64.

Hatar, A. (2003). Jordan and Israel normalization, lecture at the Jordanian Engineering Union, Amman, September, 2.

Haywood, R. (1998). Overview of globalization and the impact of free zones, World Economic Processing Zones Association, No. 3, Ver. 1, USA.

Haywood, R. (2000). Free zones in the modern world, Evergreen, Colorado, CFATF Meeting, Aruba, World Economic Processing Zones Association No. 5 Ver. 1 October.

Haywood, R. (2003). Developing trade capacity through Free Zones, World Economic Processing Zones Association, Casablanca, Morocco, December.

Haywood, R. (2003). Pre-feasibility Study of an Export Processing Zone in Vanuatu, United Nation Publication, UNESCAP programme, August.

Haywood, R. (2004). Overview of globalization and the impact of free zones, World Economic Processing Zones Association (WEPZA).

Holland, D. and Vann, R. (1998). Income Tax Incentives for Investment, Tax Law Design and Drafting, Vol. 2, International Monetary Fund, Victor Thuronyi, ed. Ch.23.

Horst S. (1998). Commentary: Economic consequences of income inequality Federal Reserve Bank of Kansas City, pp 265-281. 
Herzer,D., Nowak-Lehmann F., D., and Siliverstovs B., (2004). Export-Led Growth in Chile: Assessing the Role of Export Composition in Productivity Growth, Ibero-America Institute for Economic Research, Georg-August-Universität Göttingen, November.

Herzer, D. and Nowak-Lehman F., D. (2005). What does export diversification do for Growth? An econometric Analysis, Ibero-American Institute for Economic Research, University of Göttingen, Germany.

Herzer, D., Nowak-Lehmann F. D., and Klasen, S. (2006). In search of FDI-led growth in developing countries, Ibero-America Institute for Economic Research, Georg-AugustUniversität Göttingen, July.

International Labour Organization (ILO) (1998). Export processing zones: Addressing the social and labour issues, Bureau for Multinational Enterprise Activities (MULTI), October.

International Labour Organization, (2000). Labour practices in the footwear, leather, textiles and clothing industries, Report for discussion at the Tripartite Meeting on Labour Practices, Geneva.

International Labour Organization (ILO), (2003). ILO database on export processing zones, International Labour Organization publication, Sectoral Activities Department.

International Confederation of Free Trade Unions (ICFTU), (2003). Export Processing Zones, Symbols of Exploitation and a Development Dead-End, September.

International Monetary Fund, Jordan country report, can be found at www.Imf.org.

Jauch, H., Keet, D., and Pretorius, L. (2002). Export processing zones in southern Africa: economic, social and political implications, Institute of Development \& Labour Law, University of Cape Town, August.

Jayanthakumaran, K. (2002). An Overview of Export Processing Zones: Selected Asian Countries, University of Wollongong, Department of Economics, Working Paper Series.

Jayanthakumaran, K. (2003). Benefit-Cost Appraisals of Export Processing Zones: A Survey of the Literature, Development Policy Review, Vol. 21, No. 1, pp 51-65.

Jenkins, M., Esquivel, G., and Larraín, F. (1998). Export Processing Zones in Central America, Harvard Institute for International Development, Development Discussion Paper No. 646, August.

Johansen, S. and Juselius, K. (1990). Maximum Likelihood Estimation and Inference on Cointegration with applications to the Demand for Money, Oxford Bulletin of Economics and Statistics, Vol. 52, No.2 pp 169-210. 
Jordan Garment, Accessories \& Textiles Exporter' Association (JGate), (2005). Sustaining Jordan’s Competitive Edge.

Jordan National Competitiveness Team, (2002). Jordan's Competitiveness Book, Qualifying Industrial Zones (QIZs), Ministry of Planning and International Cooperation.

Jordan Times, (2004). Economic Pulse, Role of exports in economic growth, April 19.

Jordan Times, (2005). Your Say letter to the editor, Monday, July 18.

Justin, Y., and Yongjun, L. (2002). Export and Economic Growth in China: A DemandOriented Analysis, No. E2002009. Peking University, December.

Jung, S.W., and Marshall P.J. (1985). Exports, Growth and Causality in Developing Countries, Journal of Development Economics, Vol. 18, No. 1, pp 1-12.

Kanaan, T. H. (2000). The Aqaba Special Economic Zone, Economic Rationale and Conditions for Success, The Arab Bank Review Vol. 2, No. 2, October.

Kardoosh M. (2002). Peace and its discontents: economic cooperation between Jordan and Israel, the Daily Star newspaper, August 10 . Can be found at http://www.dailystar.com.lb

Kardoosh, M. (2004). Qualifying Industrial Zones and the Jordanian Quest for Sustainable Development, the Jordanian Center for Public Policy Research and Dialogue.

Knoth, C. (2000). Special Economic Zones and Economic Transformation: The case of the People's Republic of China, PhD thesis, University of Konstanz, Germany.

Kohler, U., and Kreuter F. (2005). Data Analysis using Stata, Stata Corp LP.

Kokko, A. (2001). Export-Led Growth in East Asia: Lessons for Europe's Transition Economies, International Institute for Applied Systems Analysis, October.

Kravis, I. B., (1970). Trade as a handmaiden of growth: Similarities between the nineteenth and twentieth centuries, Economic Journal, Vol. 80, pp 850-872.

Krauss, J. (2005). QIZ \& Tell, Business Today, Egypt, January.

Kruger, A. (1978). Foreign Trade Regimes and Economic Development: Liberalization Attempts and Consequences, National Bureau of Economic Research (NBER).

Krueger, A. (1985). The experience and lessons of Asia super exporters: The Success of Five Newly Industrialized Countries, London, Westview Press. 
Krugman, P. (1998). The Role of Geography in Development, Annual World Bank Conference on Development Economics, Washington, D.C., April 20-21.

Kunst, R. M., and Maria, D. (1989). On exports and productivity: A causal analysis, Review of Economics and Statistics No. 71, pp 699-703.

Kuznets, S. (1955). Economic growth and income inequality, American Economic Review ,45 pp 1-28.

Kyaw, S. (2003). Foreign Direct Investment to Developing Countries in the Globalised World, Paper Presented at the DSA Conference University of Strathclyde, Glasgow 1012 September.

Labour Resource and Research Institute (LaRRI), (2000). Export Processing Zones in Namibia: Taking A Closer Look, Labour Resource and Research Institute publication, Namibia, March.

Lerch, S. (2004). Impacts of Tax Exemptions: An Overview, Washington State Institute for Public Policy, Document No. 04-01-4102, January.

Louis, T., et al., Using Tax Incentives to Compete for Foreign Investment:Are They Worth the Costs?, FIAS Occasional Paper 15.

Madani, D. (1998). A Review of the Role and Impact of Export Processing Zones, World Bank publication.

Manneh, J. (2003). Qualifying Industrial Zones, Sector Report, research and studies, Export Finance Bank.

Mawson, P., Carlaw K., and McLellan, N. (2003). Productivity measurement: Alternative approaches and estimates, New Zealand Treasury, June.

McKenney, K. (1993). An Assessment of China's Special Economic Zones, The Industrial College of the Armed Forces National Defense University, Washington, D.C.

Meng, G. (2003). The Theory and Practice of Free Economic Zones: A case of Tianjin, People's Republic of China, PhD thesis, University of Heidelberg, Germany.

Michaely, M. (1977). Exports and Economic Growth: An Empirical Investigation, Journal of Development Economics, Vol. 4, pp 49-53.

Mireri, C. (2000). The Impact of Export Processing Zone Development on Employment Creation in Kenya, Singapore Journal of Tropical Geography, Vol. 21, No. 2, pp 149165.

Miyagiwa, K. F. (1986). A Reconsideration of the Welfare Economics of a Free Trade Zone, Journal of International Economics Vol. 21, pp 337 - 350. 
Ministry of Industry and Trade bulletin, different issues, Government of Jordan, can be found at www.mit.gov.jo

Ministry of Planning (MOP), Government of Jordan, can be found at www.mop.gov.jo

Moore, P. W. (2003). The Newest Jordan: Free Trade, Peace and an Ace in the Hole, Middle East Report Online, June.

Morisset, J. (2003). Using Tax Incentives to Attract Foreign Direct Investment, World Bank, Private Sector and Infrastructure Network, Note NO. 25, January.

Mukherjee Ch., White H. and Wuyts M. (1998), Econometrics and data analysis for Developing countries, Routledge.

Nam, C. W. and Radulescu, D., M. (2004). Types of tax concessions for attracting foreign direct investment in free economic zones, CESIFO Working Paper No. 1175, April.

National statistic, (2006). Productivity and Value Added Calculation, Republic of China, March.

NG, C., and Whalley, J. (2004). Geographical Extension of Free Trade Zones as Trade Liberalization: A Numerical Simulation Approach, CESifo Working Paper No. 1147, March.

Ninh, N. (2001). An Evaluation of Export Processing Zones in Vietnam's Industrialization Process, Master thesis, National Economics University, Vietnam.

Okasheh, B. (1996). Evaluation of Jordanian Free Zones Experience, Master thesis, University of Jordan, Jordan.

Orbach, B. (2004). Egyptian Officials Visit Israel to Discuss QIZs, Daily Star newsletter (Beirut), March 25, can be found at www.dailystar.com.lb.

Organization for Economic Co-operation and Development (OECD), (2000). Small and Medium Enterprise Outlook, OECD outlooks.

Organization for Economic Co-operation and Development (OECD), (2001). Measures of productivity, Measurement of Aggregate and Industry-Level productivity Growth, OECD manual.

Organization for Economic Co-operation and Development (OECD), (2003). Checklist for Foreign Direct Investment Incentive Policies, OECD Publication.

Osreer, M. (1996). A Theoretical Study on the Free Zones, Experience of South Korea, Hong Kong, Singapore and Egypt, Master thesis, University of Algeria, Algeria. 
Oxford Business Group, (2005). Jordan Country Profile, can be found at http://www.oxfordbusinessgroup.com

Pernia, E. M. and Quibria, M. G. (1999). Poverty in Developing Countries, Handbook of Regional and Urban Economics, ed. 1, volume 3, chapter 45.

Perron, P., and Vogelsang T.J. (1992). Nonstationary and Level Shifts with an Application to Purchasing Power Parity, Journal of Business and Economic Statistics Vol. 10, pp 301-320.

Prados, A. B., (2006). Jordan: U.S. Relations and Bilateral Issues, CRS Report for Congress, April.

Pretorius, L. (2001). Industrial free zone legislative in Mozambique, A case study of the MZAL aluminium smelter, International Labour Resources and Information Group (ILRIG), May.

Princeton University, (2006). Data and Statistical Services can be obtained from the following link: http://dss.princeton.edu/online_help/analysis/panel.htm.

Radelet, S. (1999). Manufactured Exports, Export Platforms, and Economic Growth, Harvard Institute for International Development, CAER II Discussion Paper No. 43, November.

Ram, R. (1987). Exports and Economic Growth: Evidence from Time-Series and CrossSection Data, Economic Development and Cultural Change, Vol. 36 pp 51-72.

Ram, Y. (2003). An empirical examination of the export-led growth hypothesis in Fiji, Economics Department, Reserve Bank of Fiji, December.

Rangarajan, C., and Sundarajan, V. (1976). Impact of export fluctuations on income - A cross country Analysis, MIT press, Journal of Review of Economics and Statistics, 58, 3, pp $368-372$.

Reynolds, C. (1963). Domestic consequences of export instability, the American Economic Review, Vol. 53, No. 2, pp 93-102.

Riezman, R., Summers P. M., and Whiteman C. H. (1996). The engine of growth or its handmaiden? A time series assessment of Export-led growth, Empirical Economics Vol. 21, No. 1, pp 77-110.

Rodriguez C. A., (1976). A note on the Economics of the Duty Free, Journal of International Economics, Vol. 6, No. 4, pp 385-388.

Rolfe, R. J., Woodward, D. P., and Kagira, B. (2003). Footloose and Tax Free: Incentive Preferences in Kenyan Export Processing Zones, Conference of the Economic Society of South Africa, Somerset West, South Africa, 17-19 September. 
Ryal, Z. (1997). Free Zones and Development, Study in Industrial Export Zones the Case of Tunisian, Morris Island and The Horizon of Established Free Zone in Algeria, Master thesis, University of Algeria, Algeria.

Sadni-Jallab, M., and de Armas, E. B. (2002). A Review of the Role and Impact of Export Processing Zones in World Trade: The Case of Mexico, International Conference on "Exchange Rates, Economic Integration and the International Economy" The Department of Economics, Ryerson University, Toronto, Canada May, 17-19.

Saget, C. (2001). Is the Minimum Wage an Effective Tool to Promote Decent Work and Reduce Poverty? The Experience of Selected Developing Countries, International Labour Organization (ILO).

Saif, I. (2002). Trade Policies, Wage Level and Profitability in the Manufacturing Sector in Jordan (1976-1998), ERF Working Paper Series, Working Paper 0233, Economic Research Foroum.

Salvatore, D. (1993). International economics, 4 ed., Macmillan publishing company.

Sammour, E. (1995). Jordan Free Zones, Study in Geography of Development, Master thesis, University of Jordan, Jordan.

Schweinberger, A. G. (2003). Special Economic Zones in Developing and/or Transition Economies: a Policy Proposal, Review of International Economics, Vol. 11 No. 4, pp 619-629.

Schwellnus, C. (2003). Export Processing Zones: Economic Effects and Poverty Impact report prepared for the Southeast Asia Department of the Asian Development Bank, August.

Scott, R. E. (2003). The high price of free trade, NAFTA's failure has cost the United States jobs across the nation, Economic Policy Institute, briefing paper, Washington, November.

Sekaran, U. (19992). Research Methods for Business: A skill-building approach, $2^{\text {nd }}$ edt, John Wiley and Sons Inc.

Shan, J. and Sun, F. (1998). On the Export-Led Growth Hypothesis: The Econometric Evidence from China, Applied Economics, Vol. 30, No. 8 pp 1055-1065.

Shanks, S. and Zheng S. (2006). Econometric Modelling of R\&D and Australia's Productivity, Staff Working Paper, Productivity Commission, Australian Government, April.

Sharma, A. and Panagiotidis, T. (2004). An Analysis of Exports and Growth in India: Cointegration and Causality Evidence (1971 - 2001), Department of Economics, Loughborough University, UK. 
Shigemi, Y. (2000). Export Processing Zones, Backward Linkages, and Variable Returns to Scale, Review of Development Economics, vol. 4, issue 3, pp 268-278.

Sinclair, R. D. (2001). Export Processing Zones: An Ingredient for Successful Liberalization, The Maxwell School of Syracuse University, Department of Economics, May.

Stanford, R. A. (2000). Let the Textile Industry Go! Can be found at http://facweb.furman.edu/ dstanford/mbnotes/textile.htm, May.

Stock, J. H., and Watson M. W. (2003). Introduction to econometrics, Pearson education, Inc.

Stokes, R., and Jaffy, D. (1982). Another look at the export of raw materials and economic growth, American Sociological Review, 47, 3, pp 402-407.

Subasat, T. (2002). Does Exports Promotion Increase Economic Growth? Some CrossSection Evidence” Development Policy Review, Vol. 20, pp 333-349.

Tahir, J. (1998). An Assessment of Free Economic Zones (FEZs) in Arab Countries: performance and main features, international conference on "New Economic Developments and Their Impact on Arab Economies” Tunis, 3-5 June.

Tekere, M. (2000). Export Development and Export-led Growth Strategies: Export Processing Zones and the Strengthening of Sustainable Human Development, African Meeting - Discussion Notes, May.

The American Chamber of Commerce in Jordan, a View of Jordanian Investment Locations can be found at this website: http://www.amcham.jo/.

Thirlwall, A.P. (unknown date). Trade, The Balance of Payments and Exchange rate Policy in Developing Countries, University of Kent at Canterbury.

Tiebout, C. (1956). Export and Regional Economic Growth, Journal of Political Economy Vol. 64, 2, pp 160-164.

Tosun, M. S. (2003). An Analysis of Tax Structure Changes in the MENA Region in Response to Trade Liberalization, Bureau of Business and Economic Research, College of Business and Economics, West Virginia University, October.

Tsui, K. Y. (1993). Welfare effects and Optimal Incentive Package of Export Processing Zones, International Economic Journal, Vol. 7, No. 2.

Turan, S. (2002). Does Export Promotion Increase Economic Growth? Some CrossSection Evidence Development Policy Review, 20, 3, pp 333-349. 
Ukrainian Center for Independent Political Research, (2000). Free economic zones in Ukraine: genesis, trends and prospects, Vol. 6, No. 189, October, 2.

Tybout, J. (2003). Topics in International Trade, Pennsylvania State University, Department of Economics, Lecture 9.

United Nations Conference on Trade and Development (UNCTAD), (1973). Export Polices in Developing Countries, the use of free zones as a means of expanding and diversifying exports manufactures from the developing countries, Geneva Agenda, August.

United Nations Conference on Trade and Development (UNCTAD), (1973). Export Processing Free Zones in Developing Countries: Implications for trade and industrialization policies, United Nation publication.

United Nations Industrial Development Organization (UNIDO), (1980). Export Processing Zones in Developing Countries, UNIDO Working Papers on Structural Changes No. 10, UNIDO /ICIS, Vienna, August.

United Nation Industrial Development Organization (UNIDO), (1997). Industrial estates principles and practice, UNIDO Publication.

United Nation Industrial Development Organization (UNIDO), (2000). Tax Incentives and Foreign Direct Investment, ASIT Advisory Studies, No. 16.

United Nations Relief and Works Agency for Palestine Refugees in the Near East (UNRWA), (2005). Jordan Refugee Camp Profiles, can be found at http://www.un.org/unrwa/refugees/jordan.html, March.

United Students Against Sweatshops, (2004). Report on International Internship in Jordan, American Center for International Labor Solidarity.

USA embassy, (1999). Development of QIZs in Jordan, press release, can be found at http://usembassy-amman.org.jo/3QIZ.html.

Walker, R. (2003). In-Depth Policy Analysis: Tax-Free Zone Initiatives, Policy Research Assistant, League of Minnesota Cities, June.

Warr P. (1989). Export Processing Zones: The Economics of Enclave Manufacturing, Research Observer 4, No. 1, The World Bank January.

Watoon, P. L. (2001). Export Processing Zones: Has Africa Missed the Boat? Not yet!, Africa Region Working Paper Series, No. 17, May.

Wei, Ge, (1999). The Dynamics of Export-Processing Zones, United Nations Conference on Trade and Development (UNCTAD). 
Wooldridge, J. M. (2003). Introductory Econometrics: A Modern Approach, 2 edition, south-western Publisher of Thomson Learning.

World Bank, (1998). Export processing zones, Prem notes, economic Policy, No. 11, December.

World Bank, (2003). Jordan Country Unit, A Quarterly Publication of the World Bank Group, first quarter.

World Bank, (2004). The role of exports and qualified industrial zones in economic growth, Hashemite Kingdom of Jordan Update, World Bank publication, Q4.

Yabuuchi, S. (2000). Export Processing Zones, Backward Linkages, and Variable Returns to Scale, Review of Development Economics, Vol. 4 No. 3, pp, 268-27.

Yi, Bian, (2005). China Cheap labour cannot last, China Daily, downloadable from: http://www.chinadaily.com.cn/english, August.

Young, L., and Miyagiwa, K. (1987): Unemployment and the Formation of Duty Free Zones, Journal of Development Economics, Vol. 26, pp 397-405.

Zhang, X., and $\mathrm{Hu}$ J. (1999). Behind Free Trade: Import and China's Economic Development, Inter trade, vol. 208.

Zemer, L., and Pardo, S. (2002). An Alternative Euro-Israeli Dispute Resolution, Proposal for the "Rules of Origin" Saga, Jean Monnet Working Papers, Department of Political Studies - University of Catania, it December.

Zohir, S. C. (2001). Gender Balance in the EPZ: A Socio-Economic Study of Dhaka Export Processing Zone in Bangladesh, Bangladesh Institute of Development Studies, February. 


\section{ACKNOWLEDGMENTS}

I am not alone, because the Father is with me.

(John 16, 32)

This dissertation would not have been possible without the support and encouragement of many people. My greatest thanks go to my parents, sisters, and brothers for their encouragement, prayers, and support to continue my studies. My thanks go also to my uncles, aunts, and other relatives, for the encouragement and support.

I am thankful to my supervisor Prof. Dr. Kilian Bizer for accepting me as a Ph.D. student, and for the support, guidance and advices he gave me during the writing of this thesis. I also want to thank Prof. Dr. Michael Grimm for his valuable advices and comments, which help me to complete writing this thesis. My thanks go also to Prof. Dr. Dr. h.c. Jürgen Bloech for his valuable comments.

I would like to thank Ulrika Witze, Karin Behler, Dr. Klaus Müller and Dr. Ullrich Kornhardt in the ifh institute for providing me with a warm and supportive environment to finish writing this thesis. My thanks go also to my friends Dr. Emad Akkawi, Fadi Makdsi, Christoph Sauer, Adriana Rocío, Anja Sölter, Cecilia León, Dana Schüler, Katarzyna Cisz, Jennifer Dreyer, Zulia Gubaydullina, Nicolaus zu Wittgenstein, Steffen Reißig, Jan Schlimgen, Josh Wittrock, Julian Weisbrod, and Stefan Gelzer, for the good time I spent with them in Germany. A very special thanks to my friend Alfred Ashak and his family for the hospitality and care that they showed me during my stay in Germany. My thanks go also to my friend Abdullah Masarweh for his encouragement during my stay in Germany. I owe special thanks for Marjory Frauts, Lori Gayle and Amanda Wingard-Philips, who edited significant portions of this thesis.

I would like to express my thanks to his Excellency Dr. Mohammad Abu Hammour and his Secretary General Dr. Hamed Kasasbah for their encouragement and support to continue my studies. I would like to extend my sincere thanks also to my boss at the 
Ministry of Finance in Jordan Dr. Ismail Zaghloul and my friends Essa Saleh and Jean Mulot for their encouragement and valuable advices. My thanks and appreciation goes also to my friend Dr. Hazim Rahahleh for his help to continue my studies in Germany. My thanks also go to my colleagues at the Ministry of Finance: Eman Jabri, Norma Al Hersh, Shatha Yousef, Hanadi El Refaee, Ethar Al Shareef, Ayman Khalaileh, Dr. Iyad Malkawee, Dr. Jamal Al Himsi, Omar al Zoubi, Wolfgang Schaft, and all the others.

I also wish to thank my friends Dr. Nayef Zu’bi for his advice and Dr. Maher Al Mahrouq for his support and help in designing the questionnaire.

I am grateful for the financial support from the Katholischer Akademischer AusländerDienst (KAAD). I will never forget also the hospitality and the kindness from the KHG team in Göttingen, Daniela Ramb and Heiner J. Willen. I am highly indebted to Gabriele Beitzel for her ample kindness and advice, which help me a lot during my stay in Germany.

A special thank you accompanied with my sincere apology for all the friends whom I forgot to mention in this acknowledgement. 


\section{Curriculum Vitae}

Name

Private Address

E-mail

Date of Birth

Place of Birth

Nationality
Metri Fayez Al Mdanat

Amman, Dahyiet Al Housien

P.O. Box 950233, Amman 11195, Jordan

metromics@hotmail.com

December, 211972

Karak / Jordan

Jordanian

\section{Education}

2004 -2006 Göttingen, Georg- August-Universität Ph.D. Student in Economics Germany

1997 - 2000 Amman, University of Jordan Master degree in Economics Jordan

1990 - $1994 \quad$ Karak, University of Mu'tah

Bachelor degree in Economics and Jordan Political Science

1990 Karak

The General Secondary Education Certificate Examination

\section{Present Post.}

2000-present Economist Government of Jordan / Ministry of Finance

I was responsible for conducting research in economic and finance / Jordanian Economy, inc: -Appraising the effects of government fiscal policy on the performance of the economy, recommending fiscal measures to the Minister and Secretary General of Finance appropriate to situation,

-Developing forecasting models for monitoring and analyzing public revenues. 
Memberships

$2000-2004$

Ministry of Finance

Member in the revenue forecasting task force,

Ministry of Finance

Member in the Medium Term Financial Framework (MTFF) task force

\section{Professional Experience Record}

\begin{tabular}{|c|c|c|c|c|}
\hline $1999-2000$ & $\begin{array}{l}\text { Amman, } \\
\text { Jordan }\end{array}$ & $\begin{array}{l}\text { The Finance } \\
\text { Investment } \\
\text { Group }\end{array}$ & Economist & $\begin{array}{r}\text { - Conduct } \\
\text { Studies }\end{array}$ \\
\hline $1998-2000$ & $\begin{array}{l}\text { Amman, } \\
\text { Jordan }\end{array}$ & $\begin{array}{l}\text { Jordan } \\
\text { University }\end{array}$ & Researcher Assistant & $\begin{array}{l}\text { - Professors Assistant } \\
\text { - Preparing and holding } \\
\text { of seminars \& lectures } \\
\text { - Conduct Studies on } \\
\text { Competitiveness in } \\
\text { Local Market }\end{array}$ \\
\hline $1998-1998$ & $\begin{array}{l}\text { Amman, } \\
\text { Jordan }\end{array}$ & $\begin{array}{l}\text { Department of } \\
\text { Statistics }\end{array}$ & Researcher & $\begin{array}{l}\text { Survey for the } \\
\text { Agriculture Census } \\
\text { Baseline study on } \\
\text { regional level Inc: } \\
\text {-Supervising the } \\
\text { Agriculture Census } \\
\text { Survey/Ma'an District }\end{array}$ \\
\hline
\end{tabular}

\section{Selected Workshops and Conferences}

2004

2003

2002

2001
Greece, Athens

United States Department of Agriculture

Amman, Jordan Jordan Administration Institute

North Carolina ,USA

Duke University

Amman, Jordan
Harvard University in Cooperation with GTZ
International Conference on "The use of Economic Incentives in Environmental Decision-Making”.

Workshop on "Financial Analyses "

Workshop entitled "Tax Analysis \& Revenue Forecasting " Workshop entitled "Tax Analysis \& Revenue Forecasting " 


\section{Languages}

Arabic, English, Fair Knowledge of German

\section{IT Knowledge and Econometric software}

MS Office (Excel, Power Point, Word), SPSS, STATA, E-views

\section{Selected Papers}

-Export and Economic Growth in Jordan, with Bizer.k., Georg-August-Universität Göttingen, mimeo, 2005.

- Medium Term Financial Framework 2004 - 2007. Ministry of Finance, June 2004.

-The Advantage and Disadvantage of Fixing the Jordanian Dinar to US Dollar. MoF, unpublished. February, 2004.

-The Impact of Rising Fuel Prices on The law-income Groups, Inflation and the Treasury. MoF, unpublished. May, 2003.

-The Impact of the Euro on The Jordanian Economy. MoF, unpublished. February, 2003.

-Tax Expenditure Study for Income Tax in Jordan. MoF, unpublished. November, 2002.

-Tax and Non Tax Revenue Forecasting. MoF, unpublished. August, 2002.

-The Economic Impact of Privatizing Jordan Cement Factory. MoF, unpublished. August, 2001.

-The Impact of Taxes on Foreign Direct Investment in Jordan. MoF, unpublished. March, 2001.

-Carbon Tax As a Source of Revenue, MoF, unpublished. June, 2001. 


\section{EIDESSTATTLICHE ERKLÄRUNG}

Ich versichere an Eides Statt, dass ich die eingereichte Dissertation "The Fiscal and Economic Impact of Qualifying Industrial Zones" selbstständig verfasst habe. Anderer als der von mir angegebenen Hilfsmittel und Schriften habe ich mich nicht bedient. Alle wörtlich oder sinngemäß den Schriften anderer Autorinnen und/oder Autoren entnommenen Stellen habe ich kenntlich gemacht.

Göttingen, 10/10/2006

Metri F. Al Mdanat 